DEDALUS - Acervo - IGC

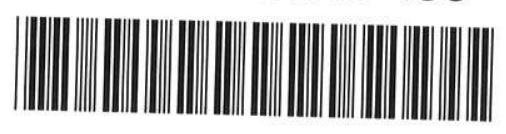

30900005721

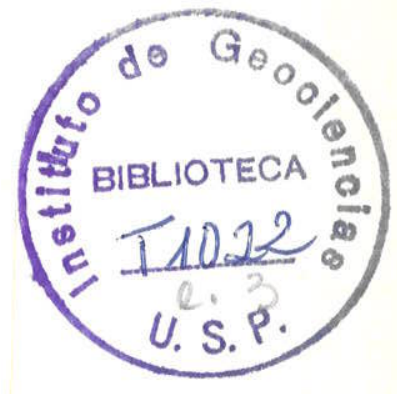

\title{
COMPOSIÇÃO QUÍMICA, ORIGEM E SIGNIFICADO GEOLÓGICO DE INCLUSÕES MINERAIS DE DIAMANTES DO BRASIL
}

Tese de Livre-Docêncla apresentada ao Instituto de Geociências da Universidade de São Paulo. 


\section{INDICE}

COMPOSIÇÃO QUIMICA, ORIGEM E SIGNIFICADO GEOLOGICO DE INCLUSOES MINERAIS DE DIAMANTES DO BRASIL 1 INTRODUÇAO

AMOSTRAGEM 3

METODOS ANALITITOS

PREPARAÇÃO DAS AMOSTRAS

$\begin{array}{ll}\text { A MICROSSONDA ELETRÔNICA } & 13\end{array}$

MINERALOGIA E QUIMICA DAS INCLUSOES

$\begin{array}{ll}\text { HISTORICO } & 16\end{array}$

ESTÁGTO ATUAL DAS PESQUISAS

CARACTERISTICAS GERAIS DAS INCLUSÕES CRISTALINAS 22

INCLUSÕES SINGENÉTICAS 26

OLIVINA 26

ENSTATITA 38

CLINOPIROXENIO

GRANADA 56

CROMIOESPINELIO

$\begin{array}{ll}\text { RUTILO } & 81\end{array}$

$\begin{array}{ll}Z \mid R C A ̃ O & 87\end{array}$

$\begin{array}{ll}\text { ILMENITA } & 91\end{array}$

PIRROTITA

$\begin{array}{ll}\text { DIAMANTE } & 101\end{array}$

INCLUSÕES EPIGENENÉTICAS 103 
$\begin{array}{ll}\text { OUTRAS INCLUSÕES } & 107\end{array}$

INCLUSŌES COEXISTENTES 109

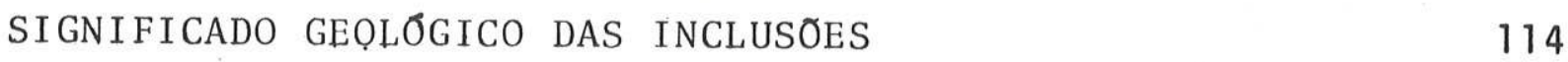

$\begin{array}{ll}\text { GÊNESE DO DIAMANTE } & 114\end{array}$

CONDIÇÕES FISICAS DE FORMAÇÃO DO DIAMANTE 115

CONDIÇÕES QUTMICAS DE FORMAÇÃO DO DIAMANTE 118 $\begin{array}{lll}\text { ORIGEM DO CARBONO } & 121\end{array}$

$\begin{array}{lll}0 & \text { DIAMANTE NO BRASIL } & 123\end{array}$

$\begin{array}{ll}\text { ORIGEM DAS INCLUSÕES } & 127\end{array}$

$\begin{array}{lll}\text { RESUMO E CONCLUSOES FINAIS } & 141\end{array}$

$\begin{array}{ll}\text { AGRADECIMENTOS } & 147\end{array}$

$\begin{array}{ll}\text { BI BL IOGRAFIA } & 148\end{array}$ 


\section{INDICE DAS ILUSTRAÇOES}

\section{FI GURAS}

Figura 1 - Locais de amostragem dos diamantes estudados

Figura 2 - Esquema do aparelho utilizado na remoção das inclusões do interior dos diamantes

Figura 3 - Esquema simplificado de uma microssonda ele trōnica

Figura 4 - Histogramas ilustrando a variação da razão $\mathrm{Mg} \times 100 / \mathrm{Mg}+\mathrm{Fe}^{2+}$ de olivinas de origens diver sas

Figura 5 - Variação do teor de $\mathrm{Cr}_{2} \mathrm{O}_{3}$ em função do teor de Mgo entre olivinas de origens diversas

Figura 6 - Histogramas ilustrando a variação da razão $\mathrm{Mg} \times 100 / \mathrm{Mg}+\mathrm{Fe}^{2+}$ de enstatitas de origens diversas

Figura 7 - Diagrama $\mathrm{Ca}-\mathrm{Mg}-\mathrm{Fe}^{2+}$ referente a inclusões de enstatitas de locais diversos

Figura 8 - Diagrama Ca-Mg-Fe ${ }^{2+}$ referente a enstatitas de origens diversas

Figura 9-Diagrama Ca-Mg-Fe ${ }^{2+}$ referente a inclusoes de clinopiroxēnios de locais diversos

Figura 10 - Diagrama $\mathrm{Ca}-\mathrm{Mg}-\mathrm{Fe}^{2+}$ referente a clinopiroxenios de origens diversas

Figura 11 - Diagrama Ca-Mg-Fe ${ }^{2+}$ referente a inclusões de granadas de locais diversos

Figura 12 - Diagrama $\mathrm{Cr}-\mathrm{Al}-\mathrm{Fe}^{3+}$ referente a inclusões de granadas de locais diversos

Figura 13 - Diagrama $\mathrm{Ca}-\mathrm{Mg}-\mathrm{Fe}^{2+}$ referente a granadas de origens diversas

Figura 14 - Diagrama $\mathrm{Cr}-\mathrm{AT}-\mathrm{Fe}^{3+}$ referente a granadas de origens diversas

Figura 15 - Variação das razões $\mathrm{Cr}_{2} \mathrm{O}_{3} / \mathrm{Cr}_{2} \mathrm{O}_{3}+\mathrm{Al}_{2} \mathrm{O}_{3}$ e $\mathrm{MgO} /$ $/ \mathrm{Mg} 0+\mathrm{FeO}$ de granadas de origens diversas 
Figura 16 - Variação do teor de $\mathrm{Cr}_{2} \mathrm{O}_{3}$ em função do teor de $\mathrm{Al}_{2} \mathrm{O}_{3}$ entre granadas de origens diversas

Figura 17 - Variação do indice de refração em função do teor de crōmio entre granadas de origens di versas

Figura 18 - Gräfico $\mathrm{Cr}-\mathrm{Al}-\mathrm{Fe}^{3+}$ referente a inclusões de cromioespinelios de locais diversos.

Figura 19 - variação das razões $\mathrm{Cr}_{2} \mathrm{O}_{3} / \mathrm{Cr}_{2} \mathrm{O}_{3}+\mathrm{Al}_{2} \mathrm{O}_{3}$ e $\mathrm{MgO} /$ /MgO+FeO de cromioespinēlios de origens diversas

Figura 20 - Variação dos teores de $\mathrm{Cr}_{2} \mathrm{O}_{3}$ e $\mathrm{FeO}+\mathrm{Fe}_{2} \mathrm{O}_{3}$ de rutilos de origens diversas

Figura 21 - Rede recíproca de uma das inclusões de ruti 10

Figura 22 - Variação da composição química de ilmenitas de origens diversas

Figura 23 - Variaçãa do teor de magnēsio e ferro II de ilmenitas de origens diversas

Figura 24 - Variação dos elementos quîmicos principais de inclusões coexistentes em diamantes

Figura 25 - Partição $\mathrm{Mg} / \mathrm{Fe}^{2+}$ entre olivinas e enstatitas constituintes de associações ultramāficas de natureza kimberlitica

Figura 26 - Campo de formação do diamante na natureza

Figura 27 - Coluna estratigräfica do Manto Superior na região sudeste do continente africano

Figura 28 - Esquema mostrando as relações entre a litosfera e a astenosfera na região correspondente ao estado de Lesotho

Figura 29 - Diagrama Ca-Mg-Fe ${ }^{2+}$ mostrando o campo de variação de clinopiroxēnios de origens diversas

Figura 30 - Diagrama $\mathrm{Ca}-\mathrm{Mg}-\mathrm{Fe}^{2+}$ mostrando o campo de variação de granadas de origens diversas 
FOTOGRAFIAS

Fotografia 1 - Espectro de raios $X$ característicos de uma inclusão, de ilmenita

Fotografia 2 - Diagrama de precessão de uma inclusão de rutilo

\section{FOTOMICROGRAFI AS}

Fotomicrografia 1 - Grupo de inclusões idiomorfas no interior de um cristal de diamante

Fotomicrografia 2 - Enxame de inclusões prismäticas vistas a nícois cruzados

Fotomicrografia 3 - Pormenor de uma olivina de häbito tabular

Fotomicrografia 4 - Pormenor de uma enstatita de häbito prismätico, biterminada

Fotomicrografia 5 - Cristal de diamante irregular incluso em diamante de häbito tabular

Fotomicrografia 6 - Diamạte de hābito octaēdrico incluso em diamante de häbito rambododecaēdri co

\section{MICROGRAFIAS ELETRONICAS}

Micrografia eletrônica 1 - Inclusão de olivina de hābito prismätico

Micrografia eletrōnica 2 - Cavidade elipsóidica em uma das inclusões de olivina

Micrografia eletrônica 3 - Inclusão de olivina de häbito globular 
Micrografia eletrōnica 4 - Cavidades paralelas em cristal de olivina equidimensional

Micrografia eletrônica 5 - Inclusão de olivina em farma de gota

Micrografia eletrônica 6 - Inclusão de enstatita prismāti ca

Micrografia eletrōnica 7 - Cristal de enstatita parcial mente clivado

Micrografia eletrânica 8 - Inclusão de diopsidio exibindo idiomorfismo perfeito

Micrografia eletrānica 9 - Cromiopiropo de hābito globular

Micrografia eletrōnica 10 - Cavidades elipsoídicas em inclusão de cromiopiropo

Mịcrografia eletrônica 11 - Inclusão de piropo-almandina desproporcionada

Micrografia eletrônica 12 - Microestrutura em uma inciusão de piropo-almandina

Micrografia eletrōnica 13 - Inclusão de cromioespinēlio de häbito octaēdrico

Micrografia eletrōnica 14 - Inclusão de rutilo de hábito prismätico

Micrografia eletrōnica 15 - Microestruturas em uma das inclusões de rutilo

Micrografia eletrônica 16 - Inclusão de zircão exibindo su perfícies abauladas

Micrografia eletrōnica 17 - Inclusão de ilmenita de hábito prismātico

Micrografia eletrōnica 18 - Inclusão de pirrotita parcialmente fraturada

Mịcrografịa eletrōnica 19 - Cristal de pirrotita de hābito tabular

Micrografia eletrōnica 20 - Inclusão epigenētica de quartzo exibindo superficies irregulares 


\section{TABELAS}

Tabela 1 - Localização geọgrāfica das amostras estudadas nes te trabalho

Tabela 2 - Minerais singenēticos e epigenēticos identifí cados como inclusões em diamantes atē o presente momento

Tabela 3-Composição quĩmica de olivinas inclusas em diamantes do Brasil

Tabela 4 - Porcentagens das moléculas constituintes das inclusões de olivina

Tabela 5 - Compasição quỉmica de enstatitas inclusas em diamantes do Brasil

Tabela 6 - Porcentagens das moléculas constituintes das inclusões de enstatitas

Tabela 7 - Composição quỉmica de clinopiroxênios inclusos em diamantes do Brasil

Tabela 8 - Composição quỉmica de granadas inclusas em diamantes do Brasil

Tabela 9 - Porcentagens das moléculas constituintes das inclusões de granada

Tabela 10 - Composição quỉmica de cromioespinēlios inclusos em diamantes do Brasil

Tabela 11 - Porcentagens das moléculas constituintes das inclusões de cromioespinēịo

Tabela 12 - Composição quĩmica de rutilos inclusos em dia mantes do Brasil

Tabela 13 - Composição quỉmica de zircões incłusos em dia mantes do Brasil

Tabeḷa 14 - Compoșição quỉmica de ilmenitas inclusas em diamantes do Brasil

Tabela 15 - Porcentagens das molēculas constituintes das inclusões de ilmenita

Tabela 16 - Compoșição química de pirrotitas inclusas em diamantes do Brasil 
Tabela 17 - Composição química de inclusões de natureza incerta

Tabela 18 - Temperaturas e pressões de formação do diaman te na natureza

Tabela 19 - Classificação química e mineralögica dos minerais singenëticos identificados em diamantes do Brasil

Tabela 20 - Anālises químicas representativas de clinapiroxēnios kimberliticos de origens diversas

Tabela 21 - Anāilises químicas representativas de granadas kimberliticas de origens diversas 


\section{COMPOSIÇAO QUIMICA, ORIGEM E SIGNIFICADO GEOLOGICO DE INCLUSOES MINERAIS DE DIAMANTES DO BRASIL}

\section{INTRODUÇAO}

0 estudo das inclusões minerais do diamante constitui um tema de pesquisa de grande interesse na atualidade devido à suas implicações com o manto superior, de onde supostamente se origina o diamante, os kimberlitos e seus xenōlitos ultramäficos e ultrabāsicos.

Atualmente, admite-se que o diamante se cristaliza em condições estāveis e prōximas de equilibrio, em profundidades si tuadas entre 150 a $200 \mathrm{~km}$ (KENNEDY e NORDLIE, 1968). Durante o crescimento, ele pode englobar, eventualmente, outros minerais desenvolvidos paralelamente, aprisionando-os na forma de inclu sões sōjidas e cristalinas. Embora ainda não haja um consenso sobre o local exato onde o diamante se forma - se no seio do mag ma kimberlitico ou em outra rocha do manto -, o fato ē que as suas inclusões constituem o ünico registro dos complexos proces sos que conduzem à formação e cristalização deste mineral na na tureza (SOBOLEV et al., 1975). De qualquer forma, o diamante pro vēm do manto, o que confere às inclusões a condição de pequenos testemunhos dessa faixa do globo colocada atualmente na frontej. ra do conhecimento das ciências geológicas. Pode-se afirmar que as inclusões constituem, juntamente com os xenōlitos dos kimber litos, janelas para o manto superior da Terra.

Diversos modelos petrológicos do manto elaborados nos ūițimos anos têm sido baseados em informações referentes à quími ca mineral dos xenölitos trazidos à superfície da crosta por kim berlitos e basaltos (BOYD e NIXON, 1973; MACGREGOR, 1975; MEYER, 1977). Entretanto, è fato bem conhecido que os minerais consti tuintes dos referidos xenōlitos estão sujejtos à uma série de mo 
dificações. Alēm das alterações intempëricas que inutilizam a major parte desses nödulos hă ainda a possibilidade deles so frerem inteirações com materiais circundantes durante a fase de ascenção, acarretando modificações substanciais na composição mineralógica e quĩmica de seus minerais integrantes. Tais fa tos não ocorrem com os minerais presentes no interior do diamañ te. Sendo o diamante um dos mais refratärios e inativos dos mi nerais, suas inclusões permanecem virtualmente inalteradas por tempo indeterminado, salvo se houver fraturas que as exponham aos agentes externos. Nessas condições, as inclusões podem ser consideradas como materiais realmente representativos da rocha matriz do diamante, e por extensão, do pröprio manto superior.

o principal objetivo deste trabalho è apresentar uma sērie de dados mineralógicos e quimicos que reunimos nos ūiti mos anos a respeito dos minerais que identificamos em diamantes detriticos provenientes das principais zonas diamantiferas do Brasil. Pretendemos em primeiro lugar, contribuir para o conhe cimento da gênese do diamante brasileiro, de vez que, uma boa parte dos trabalihos divulgados na literatura geológica levanta ram diversas düvidas e questões que não haviam sido esclareci. das atē o presente momento. Paralelamente, são discutidos e in terpretados à luz dos resultados obtidos, alguns aspectos geoló gicos possiveis de existir sob o continente brasileiro. Fina mente, esperamos que esse trabalho, que de certa forma dä cont $\bar{i}$ nuịdade a outros por nós realizados anteriormente (SVISER0,1971; MEYER e SVISERO, 1973; SVISERO, MEYER e TSAI, 1977), possa tra zer algum subsidio para o conhecimento da origem do diamante, dos kimberlitos e seus nōdulos ultramäficos, e em ūltima instāncia, do prōprio manto superior. 


\section{AMOSTRAGEM}

A tarefa de obtenção dos diamantes contendo inclusões se revestiu de uma sērie de dificuldades inerentes às caracte rísticas de produção e comercialização dessa substância no Brá sil. E fato bem conhecido que o garimpeiro, que ë o individuo que realmente minera o diamante, não fica com o produto do seu trabalho. Ele o transfere ao fornecedor do lacal que por sua vez, periodicamente, vende seus estoques aos compradores sedia dos em centros maiores, principalmente em São Paulo e Rio de Já neiro.

Dentro desse contexto, percebe-se imediatamente que o ideal seria obter os diamantes diretamente do garimpeiro,pois assim estariamos otimizando ao mäximo o grau de confiança no que diz respeito à procedēncia das amostras. Infelizmente,esse procedimento revelou-se impraticāvel; assim, com algumas raras exceções, a maịor parte dos diamantes estudados foi obtida jun to a fornecedores.

0 processo de seleção, que ainda continuamos seguindo, consiste em examinar lotes diversos com o auxilio de lupa ma nual de 10 aumentos, e eventualmente, lupa binocular de aumen tos maiores. De um modo geral, as inclusões são mais frequen tes nos lotes das categorias comerciais "indūstria" e "fundo" que reune diamantes contendo defeitos diversos. Os defeitos mais comuns são inclusões cristalinas (bolhas), clivagens e fraturas internas (jaças), geminações (costuras) e outros tipos de imper feições que tornam o diamante inadequado ao talhe, reduzindo consideravelmente seu valor comercial.

A Figura 1 mostra a localização geogräfica dos pontos de amostragem. Como se pode observar, eles são representativos dos principais centros produtores brasileiros, tanto no presen te quanto no passado. A presente amostragem sō não inclui dia mantes dos Estados do Piauí e Maranhão e dos Territörios do Ama 


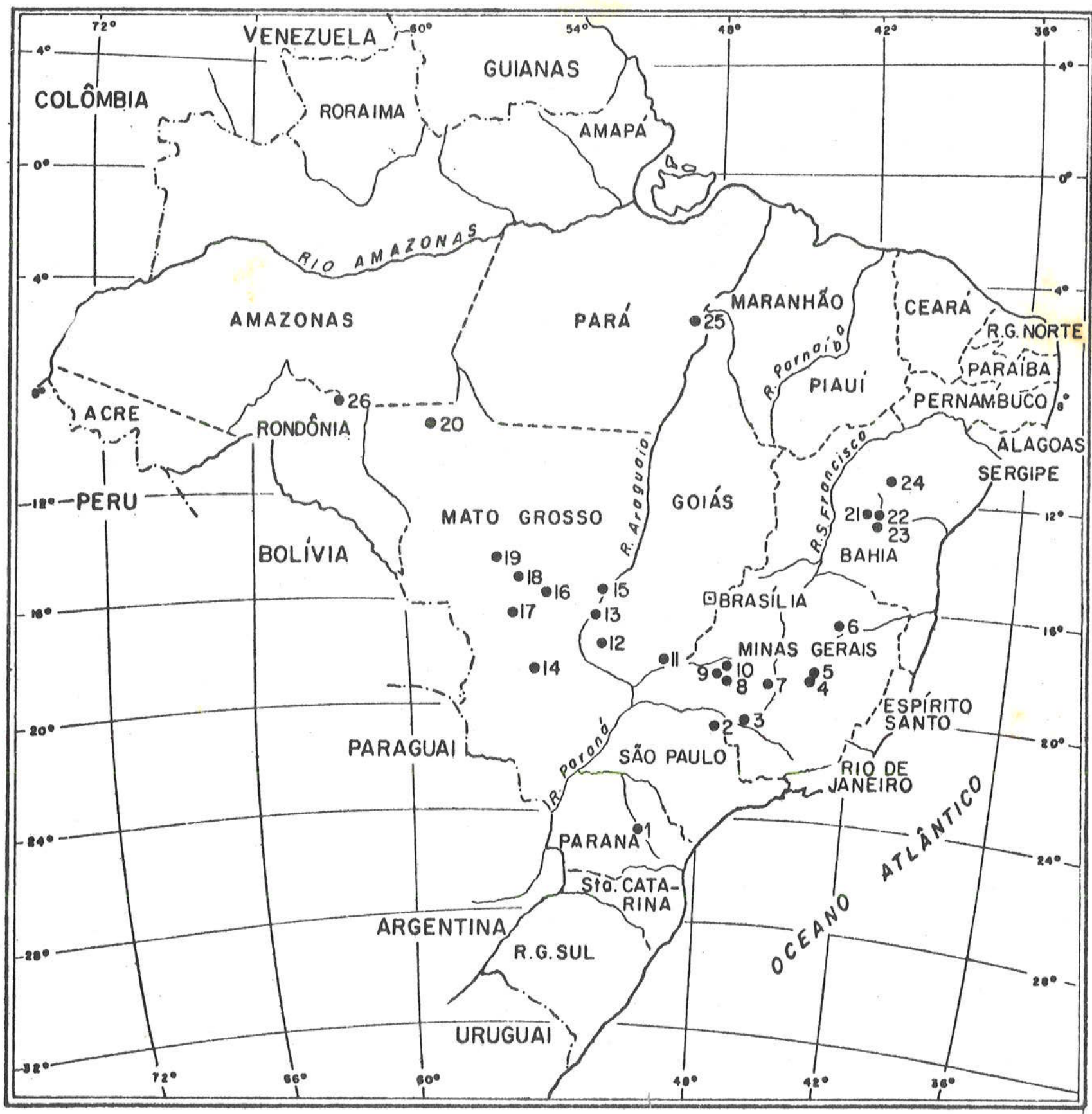

Figura 1 - Locais de amostragem dos diamantes estudados:

1) Tibagi; 2) Franca; 3) Tiros; 4) Datas; 5) Diamantina; 6) Grão Mogol; 7) Abaeté; 8) Romaria; 9) Estrela do Sul; 10) Coromandel; 11 ) Itumbiara; 12) Mineiros; 13) Baliza; 14) Coxim; 15) Barra dos Garças; 16) Poxoréu; 17) Rondonópolis; 18) Chapada dos Guimarães; 19) Diamantino; 20) Aripuanã; 21) Palmeiras; 22) Lencóis; 23) Andaraí;24)Mor ro da Chapéu; 25) Marabá; 26) Machado. 
pā e Roraima, em virtude das dificuldades de acesso aos seus ga rimpos. Deve ser mencionado que tivemos a oportunidade de ana lisar algumas amostras procedentes de garimpos do sul do Piauí, cedidas por compradores paulistas. Entretanto, preferimos om tir esses resultados levando em conta a procedēncia incerta das amostras referidas.

Durante esse trabalho, selecionamos um total de apro ximadamente 200 diamantes, catalogados por ordem de aquisição. 0 cōdigo de cada amostra é formado pela sigla do Estado de or $\underline{i}$ gem, seguida de um nūmero de ordem e de uma letra minūscula no caso do diamante conter mais de uma inclusão, aliās, um fato bastante comum. A Tabela 1 fornece outros pormenores referen tes à localização dos diamantes cujas inclusões foram analisa das neste trabalho. 
TABELA 1 - LOCAIS DE AMOSTRAGEM DOS DIAMANTES PORTADORES DAS INCLUSÖES INVESTIGADAS

\begin{tabular}{|c|c|c|}
\hline AMOSTRA & MINERAL & LOCALIZAÇAO GEOGRAFICA \\
\hline$M G-50 b$ & Cromioespinēito & Rio Jequitinhonha, Diamantina, $M G$ \\
\hline$P A-20 a$ & Cromioespinetio & Rio Tocantins, Marabā, PA \\
\hline$M T-64 b$ & Cromioespinēio & Rio São Lourenço, Rondonöpolis, MT \\
\hline$M G-40 b$ & Cromiopiropo & Rio Paranaíba,Coromandel, MG \\
\hline GO- $\mathbf{a}$ & Cromiapiropo & Rio Verde, Mineiros, Go \\
\hline$M T-15 a$ & Cromiopiropo & Rio Garças, Barra do Garças, MT \\
\hline$M G-21 a$ & Cromiopiropo & Mina de Romaria,Romaria,MG \\
\hline$P R-31 a$ & Cromiopiropo & Rio Tibagi, Tibagi,PR \\
\hline$S P-42 b$ & Cromiopiropo & Rio Sapucai-Mirim,Franca, SP \\
\hline$B A-43 a$ & Cromiopiropo & Rio Paraguaçu,Lençōis, BA \\
\hline$S P-5 a$ & Diamante & Rio Sapucaī-Mirim,Franca,SP \\
\hline$M T-6 a$ & Diamante & Rio Garças, Barra do Garças, MT \\
\hline$M G-52 a$ & Diopsidio & Mina de Romaria,Romaria. MG \\
\hline$M G-34 a$ & Enstatita & Rio Jequitinhonha, Diamantina, MG \\
\hline $\mathrm{RO}-2 \mathrm{a}$ & Enstatita & Rio Machado, Machado, Ro \\
\hline$G 0-55+a$ & Enstatita & Rio Piranhas, Piranhas, GO \\
\hline$B A-51 b$ & Enstatita & Rio Paraguaçu, Andarai, BA \\
\hline$M T-48 a$ & Enstatita & Rio Poxorēu, Poxorēu, MT \\
\hline$M G-21 b$ & Enstatita & Mina de Romaria,Romaria,MG \\
\hline$M G-27 a$ & Enstatita & Rio Bagagem, Estrela do Sul, MG \\
\hline$S P-42 b$ & Enstatita & Rio. Sapucaí-Mirim,Franca, SP \\
\hline$B A-35 a$ & Forsterita & Rio Paraguaçu, Lencöis, BA \\
\hline$R O-46 a$ & Forsterita & Rio Machado, Machado, Ro \\
\hline$R-38 a$ & Forsterita & Rio Tibagi, Tibagi, PR \\
\hline
\end{tabular}


TABELA 1 - Coṇţinuação

\begin{tabular}{|c|c|c|}
\hline AMOSTRA & MINERAL. & LOCALIZAÇAO GEOGRAFICA \\
\hline$M G-26 a$ & Forsterita & Mina de Romaria, Romaria, MG \\
\hline$M T-12 b$ & Forsterita & Rio Garcas, Barra do Garças, MT \\
\hline$M G-50 a$ & Forsterita & Rio Jequitinhonha, Diamantina, $M G$ \\
\hline$M T-15 b$ & Forsterita & Rio Garças, Barra do Garças, MT \\
\hline$B A-43 b$ & Forsterita & Rio Paraguaçu, Lençōis, BA \\
\hline$G 0-55 b$ & Forsterita & Rio Piranhas, Piranhas, Go \\
\hline$M T-64 a$ & Forsterita & Rio Aripuanã, Aripuanã, MT \\
\hline$S P-42 a$ & Forsterita & Rio Sapucai-Mirim, Franca, SP \\
\hline$M T-10 a$ & Ilmenita & Rio Taquari, Coxim, MT \\
\hline$M T-10 b$ & IImenita & Rio Taquari, Coxim, MT \\
\hline$B A-19 a$ & Ilmenita & Rio Paraguaçu, Palmeiras, BA \\
\hline GO- $-49 a$ & Ilmenita & Rio Araguaia, Aragarças, GO \\
\hline$M G-65 a$ & Onfacita & Rio Paranaíba, Coromandel, $M G$ \\
\hline$B A-47 a$ & Piropo-almandina & Rio Paraguaçu, Lençōis, BA \\
\hline$M T-22 a$ & Piropo-almandina & Rio Cuiabä, Chapada dos Guimarães,MT \\
\hline$M G-25 a$ & Piropo-almandina & Rio Abaetē, Tiros, MG \\
\hline$G 0-57 a$ & Piropo-almandina & Rio ParanaTba,Itumbiara, Go \\
\hline$M T-36 a$ & Pirrotita & Rio São Lourenço, Rondonōpolis, MT \\
\hline$M T-36 b$ & Pirrotita & Rio São Lourenço, Rondonöpolis, MT \\
\hline$M G-41 a$ & Pirrotita & Mina de Romaria,Romaria, MG \\
\hline$P R-28 a$ & Pirrotita & Rio Tibagi, Telēmaco Borba, PR \\
\hline$M T-16 a$ & Rutjlo & Rio Garças, Barra do Garças, MT \\
\hline$G 0-18 a$ & Rutilo & Rio Araguaia, Baliza, Go \\
\hline $\mathrm{RO}-61 \mathrm{a}$ & Zircão & Rio Machado, Machado, Ro \\
\hline $9 T-30 a$ & Zircão & Rio Garças, Barra do Garças, MT \\
\hline
\end{tabular}


METODOS ANALITICOS

o estudo anatîtico das inclusões envolveu, além de pro blemas diversos relacionados à preparação das amostras, o empre go de diversas técnicas incluindo microscopia öptica e eletrôni $c a$, difração de raios $x$ e microssonda eletrōnica.

Considerando que tanto a microscopia öptica quanto a difração de raios $X$ constituem atualmente métodos rotineiros na pesquisa mineralógica, não entraremos em pormenores sobre o uso dessas duas tēcnicas. Da mesma forma, não faremos tambēm maio res considerações a respeito da microscopia eletrōnica, visto que esta técnica foi por nōs usada de forma extensiva em duas oportunidades anteriores (SVISERO, 1969 e 1971). Nessas duas ocasióes, o autor discutiu alguns dos principais aspectos da microscopia eletrônica, bem como sua aplicação a diversos proble mas geolōgicos, com ènfase ao diamante. Pelos motivos citados, daremos maior atenção aos problemas relacionados à preparação das amostras e à microssonda eletrônica. Esta ültima foi o instrumento mais utilizado durante a realização deste trabalho.

\section{PREPARAÇÃO DAS AMOSTRAS}

0 primeiro cuidado que tivemos foi reexaminar, por meio de uma lupa binocular OLIMPUS, as duas centenas de diaman tes que haviam sido selecionados durante nossas viagens às zonas de garimpos. Nesta operação, descartamos todos os cristais con tendo fraturas ou cavidades capazes de conectar as inclusões com a superficie externa dos hospedeiros. Esse procedimento elimi nou, portanto, algumas amostras contendo inclusões realmente for madas dentro do diamante, porém alteradas posteriormente por agentes externos, bem como amostras contendo minerais acidental mente alojados nas cavidades e intersticios dos diamantes.

Apös essa triagem todos os diamantes considerados ade 
quados - isto $\bar{e}$, absolutamente isentos de fraturas e outros de feitos alēm das inclusões, foram submetidos a tratamentos quĩmi cos de limpeza. Primeiramente, eles foram aquecidos em HCl con centrado por vărias horas para eliminar argilas e matérias orgä nicas, e posteriormente, em HF tambēm concentrado, para eliminar fragmentos de sijlica e outros silicatos. Esse cuidado se fez necessārio pois, como jā tivemos ocasião de verificar em outras oportunidades (SVISERO, 1969), os cristais de diamante sempre retēm em suas superfícies, diversos tipos de substâncias que ali se alojam durante o tempo em que o diamante estā sendo trans portado, apōs sua formação. Se essas substāncias não forem tó talmente removidas, elas poderão ser tomadas posteriormente como inclusões primärias e falsear as interpretações referentes à na tureza mineralógica e quimica dos minerais realmente inclusos no diamante.

Como o objetivo fundamental do nosso trabalho $\bar{e}$ a de terminação quịmica quantitativa das inclusões, a passo seguinte foi isolä-las dos seus respectivos hospedeiros. A liberação po de ser feita por dois mëtodos distintos: fragmentação ou oxida ção do diamante hospedeiro. No primeiro caso o diamante é frag mentado em dispositivo especial e as inclusões são separadas dos fragmentos por meio de uma operação extremamente laboriosa com o a uxilio de um microscōpio ou lupa provida de polarizadores. Ape sar de trabalhoso, esse mētodo tem a grande vantagem de não pro vocar nenhum dano na composição química das fases liberadas. A outra possibilidade consiste em oxidar o diamante durante algu mas horas ã temperatura de $800^{\circ} \mathrm{C}$. Apesar de ser um método prāt co, por não envolver separação de minerais ao microscōpio, ele tem o inconveniente de alterar algumas inclusões, especialmente os sulfetos que são sensĩveis às variações da temperatura. Dian te dessas alternativas, optamos pelo primeiro mëtodo.

O dispositivo utilizado para fragmentar os diamantes está esquematizado na figura 2, em vista geral (2a) e em perfil (2b). Trata-se, essencialmente, de um bloco retangular (A) de 


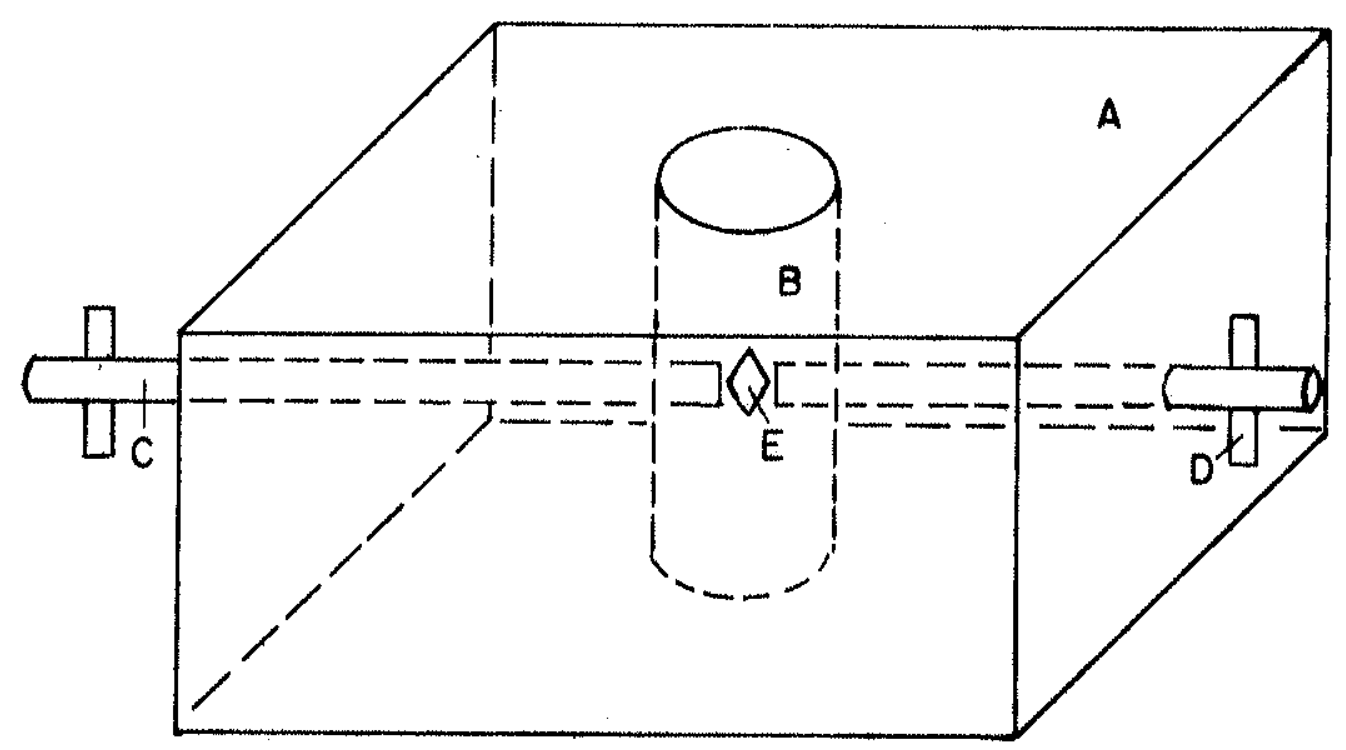

(a)

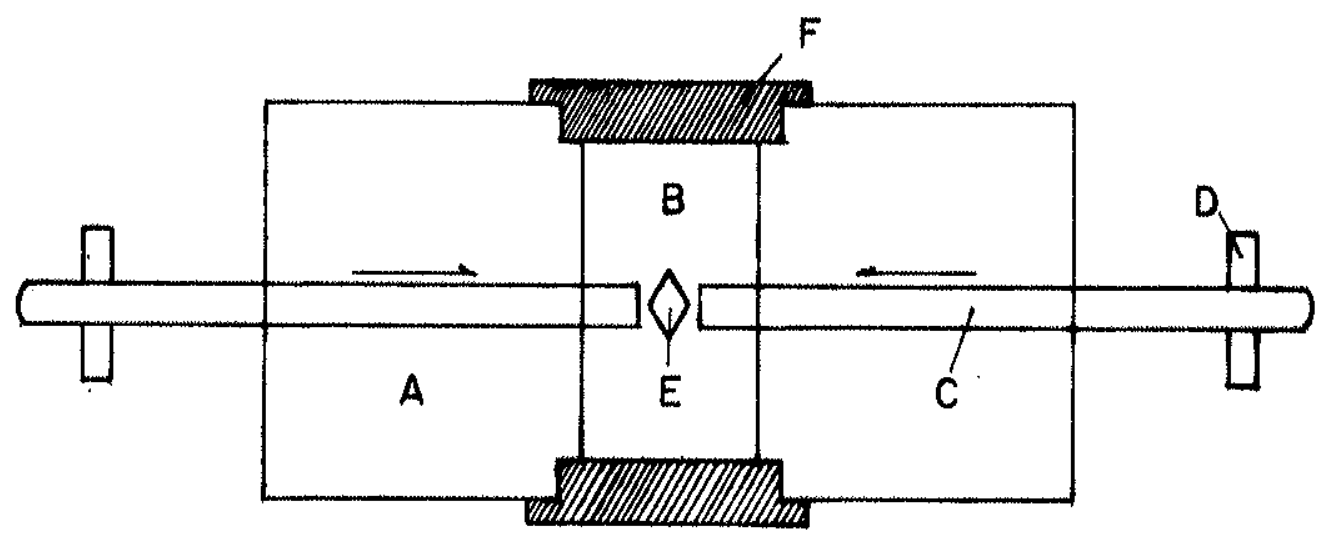

(b)

Flgura 2 - Olapositivo usado para 1solar as Lnolusöes medianta a fragmentaça do hoapadelro:

a) viata geral do conjumto (A) notando-se o olilndro (B) am oujo interior dua hastes mövels (C) bubmetem o diam mante a pressóes violentes que provooam o seu rompimentos b) Viste em perfil mostrando outros pormenorag do apareIho. O movimento de rotace das borboletes(D) desloce as duas has tos que prosionam o diamante ate o seu rompimen to. o olilndro é vadado nas duas extremidades (F) de modo reter os fragmentos de diamante as posilveds inclusões minerals. As Inclusõas são separadas, postariormente. à lupa binocular. 
aproximadamente $10 \times 7 \times 5 \mathrm{~cm}$, construído de aço inoxidāvel, de alta dureza, contendo no centro um cilindro oco de $3 \mathrm{~cm}$ de diā metro (B), interceptado por duas hastes rosqueadas (C) passíveis de serem movimentadas pelas borboletas (D) no sentido indicado pelas flechas. 0 diamante a ser fragmentado é colocado no inte rior do cilindro, suspenso entre as duas hastes, de tal forma que se girando uma das hastes, ou ambas simultaneamente, o cris tal è submetịdo a pressões intensas que provocam seu rompimento. Ao romper-se, o diamante libera suas inclusões que eventualmente podem tambēm se fragmentar.

A seguir, os fragmentos são transferidos cuidadosamen te para uma lâmina de vidro provida de uma cavidade central, e levados a uma lupa dotada de polarizadores onde se processa a se paração das inclusões. As inclusões são distinguidas dos frag mentos de diamante pelo fato de apresentarem relevo menor, hāb to definido, cor característica, e com exceção das granadas e es pinēlios, birrefringēncia de valores mëdios a altos. Nessa ope ração ē aconselhāvel utilizar um meio de imersão qualquer, ālcool ou nujol, que alēm de reduzir o relevo dos fragmentos do antigo hospedeiro permite tocar as inclusões sem que se corra o risco delas saltarem da lâmina.

Efetuada a separação, as inclusões foram submetidas a estudos diversos incluindo determinações öpticas, difração de raios $X$ e anālises quịmicas qualitativas e quantitativas. 0 em prego de um microscōpio de varredura modelo SCAN 2 fabricado pé la JEOL, alëm de ạxiliar o estudo morfológico das inclusões, fa cilitou muito o trabalho de identificação desses minerais. 0 ré ferido microscōpio contēm um analisador de raios $x$ acoplado ca paz de fornecer anālises quĩmicas qualitativas de qualquer pon to da amostra. Para facilitar ainda mais o trabalho, o espectro de raios $X$ caracterīsticos da amostra sob anālise ē projetado em uma tela fluorescente, permitindo o reconhecimento räpido dos principais elementos quỉmicos presentes. A Fotografia 1 mostra um desses espectros, referente a uma inclusão de ilmenita mostrando de forma clara e bem definida os picos correspondentes às raias 


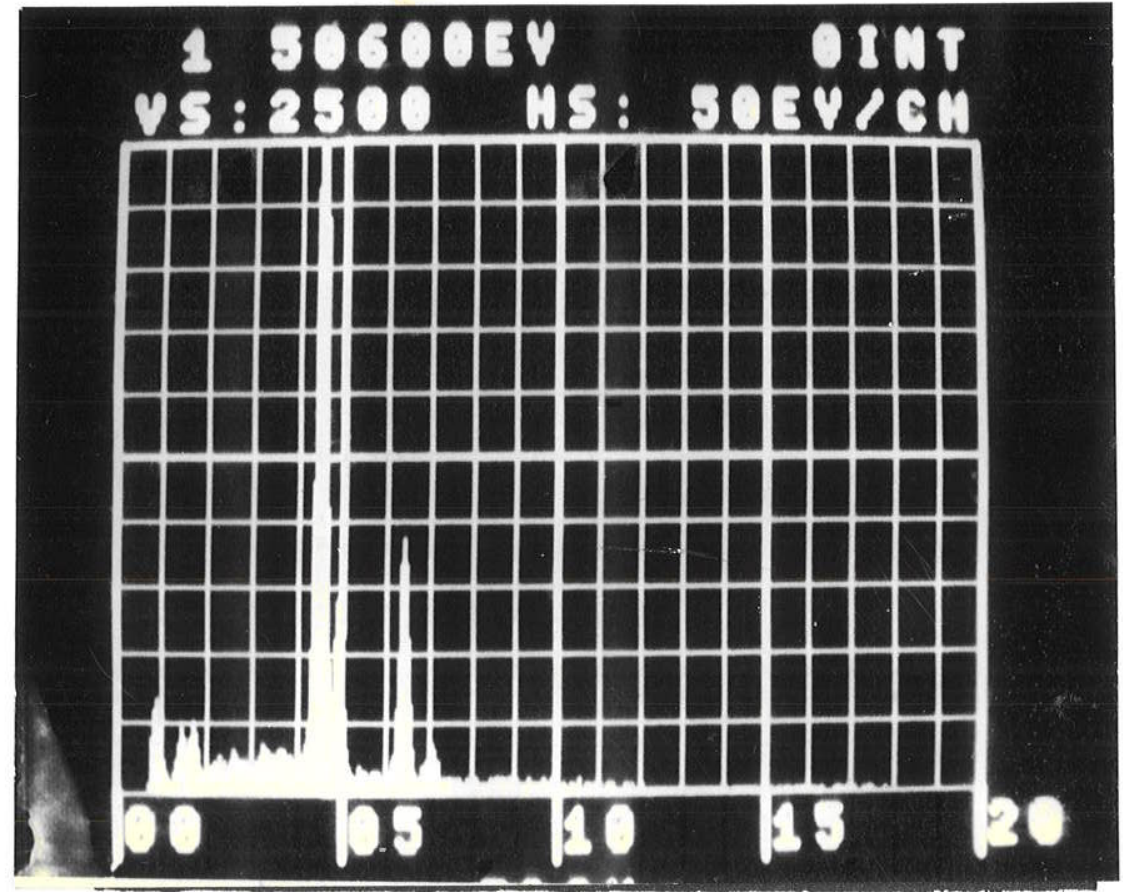
Fotografia 1 - Espectro de raios $X$ de uma inclusão de 1 imenita
destacando as raias características Ka a K $\beta$ do ti
tânio e do ferro. 
caracterīsticas $K_{\alpha}$ e $K_{\beta}$ do titānio e do ferro.

Anälises desse tipo simplificaram tanto o trabalho de identificação a ponto de tornar quase desnecessārio o uso da di fração de raios $X$. Essa ūitima tēcnica sō foi realmente neces sāria no caso de uma inclusão cujo espectro de raios $X$ só conti nha as raias $K_{\alpha}$ e $K_{\beta}$ do titānio indicando tratar-se de rutilo anatāsio ou brookita. Neste exemplo, a natureza exata do mate rial, no caso rutilo, foi estabelecida depois por meio de dia gramas de precessão. Completada a identificação, as inclusões foram montadas em secções polidas e analisadas quantitativamente na microssonda eletrōnica.

\section{A MICROSSONDA ELETRÔNICA}

Trata-se de uma das tēcnicas mais versäteis de anāli se quỉmica disponível na atualidade. A principal característi ca da microssonda eletrōnica é fornecer anāiises químicas quan titativas pontuais, isto $\bar{e}$, de pequenos setores da amostra ocu pando volumes não maiores do que alguns āngstrons cübicos. Alēm de ser uma tēcnica não destrutiva, ela permite tambēm a visual zação do material durante a anālise possibilitando dessa forma uma correlação permanente entre as propriedades morfológicas e texturais da amostra com sua composição quỉmica.

A aplicação da microssonda eletrônica a estudos de zo neamentos, intercrescimentos cristalinos e minerais de dimen söes microscōpicas, revolucionou completamente o campo das Geo ciências. 0 programa de estudo das rochas lunares e as inclu sões cristalinas da diamante, por exemplo, são alguns problemas específicos que não poderiam ter sido desenvolvidos sem o con curso dessa tēcnica. A bibliografia existente sobre a micros sonda eletrônica ē tão vasta que torna quase impossīvel sele cionar referēncias para esse pequeno capítulo. De qualquer for ma, não poderỉamos deixar de mencionar o artigo de GOMES e GI RARDI (1973) onde os autores abordam aspectos gerais do mëtodo 
e suas aplicações, essencialmente no campo geológico.

A Figura 3 mostra, de forma esquematizada, os princ $\underline{i}$ pais camponentes de uma microssonda eletrônica. Um canhão ele trōnico fornece um feixe de elēctrons que devidamente colimado par dois conjuntos de lentes magnēticas incide sobre a superfí cie polida da amostra a ser analisada. A amostra, ao ser bom bardeada pelos elēctrons, emite raios $X$ caracterĩsticos que são recebidos e analisados em espectrōmetros acoplados ao conjunto. A obtenção de resultados quantitativos exige a utilização de pa drões bem conhecidos, cuja composição quỉmica ē relacionada com a substância de composição desconhecida, efetuando-se uma sërie de medidas na sequência padrão-amostra-padrão. Dispondo-se de padrões adequados, è possĩvel obter-se anālises com precisão da ordem de $1-2 \%$.

Apesar de simples em seus princĩpios gerais, na verda de, trata-se de uma tëcnica complexa e envolvente que exige uma sērie de cuidados durante a preparação das amostras, realização das anālises e correção dos resultados fornecidos pelo aparelho. As correções analïticas constituiram a princīpio, um dos gran des entraves da tēcnica consumindo um tempo enorme em cālculos trabalhosos. Atualmente, esse obstāculo jā foi totalmente supe rado, graças à automatização total dos aparelhos mais modernos que providos de computadores são capazes de fornecer anālises quỉmicas completas de värios elementos em questão de alguns mi nutos.

As anāilises quīmicas discutidas neste trabalho foram realizadas em uma microssonda semi-automatizada, fabricada pela Material Analyses Company, modelo 500, existente no Departamen to de Geociências, da Purdue University, West Lafayette, India na, Estados Unidos da Amërica. O aparelho, operado em regime de $15 \mathrm{KV}$ e $2 \mathrm{~mA}$, dispõe de três cristais analisadores, respecti vamente LIF, RAP e PET. As correções analïticas referentes a desvios, tempo morto, radiação de fundo, absorção,fluorescēncia e nümero atōmico, foram efetuadas com o auxîlio de um computa dor utilizando os programas de BOYD et al.(1969) e HADIDIACOS et al. (1971). 


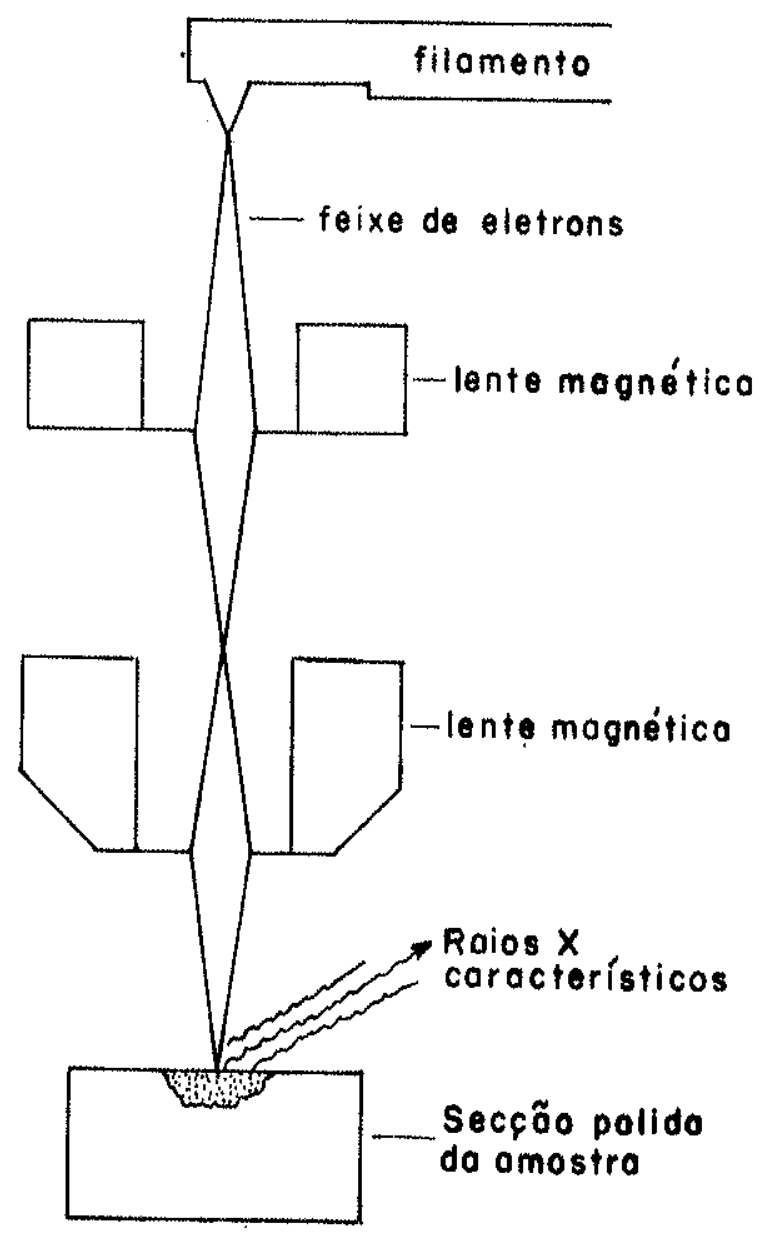

Figura 3 - Esquema simplificado de uma microssonda eletróntca. Um felxe de elétrons devidamente collmado por dols conjuntos de lentes magnéticas inclde sobre uma secção poli da da amostra; esta emite ralos X caracteristicos qué são analisados em espectrōmetros acoplados ao sistema. 
MINERALOGIA E QUTMICA DAS INCLUSOES

Durante sēculos o diamante tem sido uma das substān cias mais apreciadas e disputadas pelo homem. Quanto mais inco lor e transparente, major seu valor comercial. Entretanto, mes mo o mars perfeito dos diamantes pode ter seu valor sensivelmen te depreciado se ele contiver inclusões minerais (bolhas). Elas são relativamente raras, mas, dependendo do seu nümero, dimen são e dịstribuição no interior do diamante, podem comprometer seriamente ou mesmo impedir a lapidação da pedra. Curiosamente, esse material tão indesejado por lapidadores e comerciantes de brilhantes, $\bar{e}$ da mais alta importāncia para alguns pesquisado res pois eles encerram em si uma boa parte da histōria da or gem do diamante.

\section{HISTORICO}

0 primeiro registro de material dentro do diamante foi feito por EVELYN, no recuado ano de 1645 que mencionou a presen ça de rubi em um exemplar proveniente da India (DE BEER, 1955). Esşa observação, evidentemente, sō tem valor histōrico, pois o que EVELYN de fato deve ter visto, são as hoje familiares inclu sões de granada piropo que em geral exibem cor vermelha acentua da.

Durante o sēculo dezenove diversos autores apresenta ram referēncias esparsas a respeito de um grande nümero de subs tāncias que segundo eles, estariam inclusas no diamante. A li $\underline{s}$ ta inclui minerais de paragēneses diversas e outras substāncias como $\mathrm{CO}_{2}$ (BREWSTER, 1835), topāzio (DUMAS, 1840), quartzo (PETZHOLDT, 1842), diamante (KENNGOTT, 1853), ouro e restos de plantas (DES CEOIZEAUX, 1855), pirita' (HARTING, 1859), hematita e ilmenita (COHEN, 1876) e gases diversos (JANNETTAZ, 1879).

A descoberta dos campos diamantịferos da Africa no fi 
nal do século dezenove e princípios deste sëculo, motivou o apa recimento de uma extensa bibliografia sobre diamantes e kimberli tos contendo inumeras referēncias às inclusões conhecidas. BAUER (1904) volta a mencionar bolhas de gases e lĩquidos em canalicu los, que segundo ele, se movimentariam no interior do diamante. outras substancias descritas posteriormente como inclusões in cluiam granada (SUTTON, 1907; WAGNER, 1914), Olivina (SUTTON, 1921), magnetita (SPENCER, 1924), quartzo (COLONY, 1923; CORRENS, 1931), cromita, picotita e zircão (SUTTON, 1928) e biotita (WILLIANS, 1932).

As referencias de WILLIANS (1932) contidas em seu cële bre tratado, encerraram o que poderiamos chamar de primeira fase no estudo das inclusões. Ela se caracterizou por registros mera mente informativos, na major parte dos casos baseados unicamente em observações visuais da forma e cor dos materiais vistos den tro do diamante. Alguns dos minerais ate-aqui mencionados se riam confirmados mais tarde por mëtodos rigorosos de anälises, sen do os demais simplesmente descartados.

Credita-se a MITCHELL e GIARDINI (1953) a primazia de terem apresentado a primeira identificação inequivoca de uma in clusão. Usando difração de raios $x$, eles mostraram que a olivi na formava intercrescimentos epitäxicos com o diamante, e que o plano (010) da inclusão era paralelo ao plano (111) do hospedeiro. Esse trabalho foi seguido imediatamente por uma sērie de con tribuições semelhantes de autores russos, decorrentes da desco berta de um grande nümero de kimberlitos mineralizados na plata forma Siberiana. FUTERGENDLER (1956, 1958 e 1960), ORLOV (1959), FUTERGENDLER E FRANK-KAMENSTSKY (1961) e GNEVUSHEV e NIKOLAEVA (1961), identificaram tambëm por meio de difração de raios $X, 01 \underline{1}$ vina, piropo, cromioespinēlio, diamante, diopsidio e enstatita. alēm de vārios casos de epitaxia entre o diamante e suas inclu sões.

Por volta de 1961, MILLEDGE determinou coesita em dia mantes sintëticos produzidos pela General Electric Company nos 
Estados Unidos da Amërica. Essa descoberta teve grande reper cussão pois constituiu mais uma evidência da impossibilidade do quartzo coexistir com o diamante. Outra contribuição importan te $\vec{e}$ devida a SHARP (1966) que encontrou pirrotita e pentlandi ta em diamantes de värios locais da Africa.

A partir de 1968, trabalhos semelhantes começaram a ser desenvolvidos no Brasil. CAMARGO e LEITE (1968) identifica ram olivina em um diamante de Minas Gerais; LEITE (1969) se ré feriu a olivina, granada, cromioespinēlio e pentlandita tambēm em diamantes de Minas Gerais, enquanto SVISERO (1971, 1971a, 1974 ) descreveu olivina, granada, ortopiroxēnio,cromioespinëlio, rutilo e diamante em material procedente dos garimpos de Mato Grosso e Goiăs. Recentemente, CAMARGO e LEITE (1977), estudaram alguns casos de epitaxia entre o diamante e a olivina, observa dos em espëcimes da região do Triăngulo Mineiro, MG.

A medida que esses estudos progrediam, tornava-se ca da vez mais evidente a necessidade de se considerar a origem dos minerais ate então descritos como inclusões. ORLOV (1959) e posteriormente HARRIS (1968) estudaram minuciosamente o pro blema, e baseados no limite de estabilidade relativamente à pressão e à temperatura, dividiram as inclusões conhecidas em dois grupos distintos: singenëticas ou primärias, e epigenēti cas ou secundärias (Tabela 2). O primeiro grupo reune minerais característicos de altas pressões e temperaturas cujo campo de estabilidade è compatível com o do diamante. Pertencem a esse grupo a olivina, a granada, o piroxēnio, o cromioespinēlio, o rutilo, o zircão, a ilmenita, a coesita, alguns sulfetos como pirrotita e pentlandita, alëm do pröprio diamante.

As inclusões epigenëticas, por sua vez, são as forma das posteriormente ao diamante, e a ele associadas por episö dios subsequentes. Tais minerais não possuem nenhum vinculo ge nētico com o diamante, e portanto, são destituídos de interesse. Pertencem a esse grupo: goethita, serpentina, grafita, hematita, sellaita, caolinita, anfibölio, sanidina, limonita, turmalina, 
TABELA 2 - MINERAIS IDENTIFICADOS EM DIAMANTES NATURAIS POR MEIO DE DIFRAÇAO DE RAIOS X E/OU MICROSSONDA ELETRÕNICA

\author{
01 ivina (1) \\ Piropo (2) \\ Diamante (3) \\ Diopsídio (3)
}

Cromioespinēlio (2)

Goethita (13)

Serpentina (13)

Grafita (13)

Limonita (17)

Turmalina (17)

\section{INCLUSÕES SINGENETICAS}

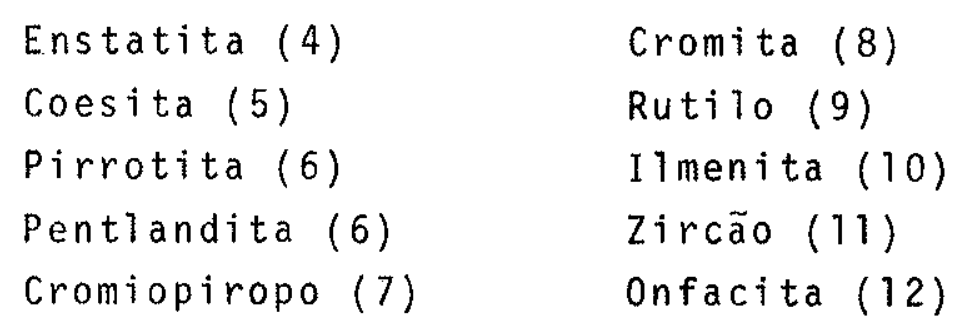

INCLUSOOES EPIGENETICAS

$$
\begin{aligned}
& \text { Hematita }(7) \\
& \text { Sellaita (7) } \\
& \text { Caolinita (7) } \\
& \text { Magnetita (17) }
\end{aligned}
$$

Anfibölio(14)

Sanidina (14)

Xenotima (7)

Quartzo (17)

Mica (17)

INCLUSÕES DE ORIGEM INCERTA

Cianita (14)

Flogopita (15)

Biotita (16)
1) MITCHELL e GIARDINI (1953)
2) FUTERGENDLER (1956)
3) FUTERGENDLER (1958)
4) FUTERGENDLER (1960)
5) MILLEDGE (1961)
6) SHARP (1966)
7) MEYER (1968)
8) HARRIS (1968)

9) MEYER e BOYD (1968)

10) MEYER e SVISERO (1973)

11) MEYER e SVISERO (1975)

12) MEYER e TSAI (1976)

13) ORLOV (1959)

14) PRINZ et al (1975)

15) MEYER (1967)

16) GIARDINI et al (1974) 
xenotima, mica, magnetita e quartzo.

A Tabela 2 inclui um terceiro grupo de inclusões cons tituído pela flogopita, biotita, e cianita, cujas relações gene ticas com o diamante nẳo estão perfeitamente definidas. Finalmen te, não poderiamos omitir as pseudo-inclusões, ou seja, manchas escuras de formato, tamanho e nümero variäveis que se distribuem pelo interior de uma grande parte dos diamantes. Na realidade, trata-se de um fenômeno öptico produzido pela reflexão total da luz atravēs de clivagens internas e outros defeitos cristalinos do diamante.

No final da dēcada passada jā havia um grande nümero de inclusões bem confirmadas e värios pesquisadores encontravam-se empenhados em obter anāilses quïmicas quantitativas desses minerais. Os primeiros resultados realmente significativos fo ram apresentados por MEYER e BOYD $(1968,1969$ e 1972), MEYER e SVISERO (1973) e paralelamente por SOBOLEV et al. $(1969,1970$ e 1971) na União Soviëtica. Trabalhos posteriores de MEYER e SVI SERO (1975), PRINZ et al.(1975), MEYER e TSAI (1976), GURNEY et az. (1977) e MEYER et az. (1977), ampliaram ainda mais as infor mações relativas à composição química das inclusões.

Nesta investigação de diamantes brasileiros identifi camos as inclusões minerais seguintes:

\section{SINGENETICAS}

EPIGENETICAS

olivina (forsterita)

grafita

ortopiroxënio (enstatita)

quartzo

clinopiroxënio (diopsidio e onfacita)

caolinita granada (cromiopiropo e piropo-alman

cromioespinētio

hematita

mica

rutilo

turmalina

zircão

magnetita

ilmenita

limonita

pirrotita

diamante 


\section{ESTÁGIO A'TUAL DAS PESQUISAS}

Embora o estudo das inclusões tenha experimentado um impulso extraordinärio nos ültimos anos, como não poderia deixar de ocorrer, hă ainda uma sërie de problemas pouco conhecidos, mas que certamente, serão objeto de investigações no futuro. Confor me tivemos oportunidade de observar durante a 2 a Conferēncia In ternacional sobre Kimberlitos realizada em Santa Fë, Estados Uni dos da América, em outubro de 1977, hä um consenso entre os pe $\underline{s}$ quisadores de que é extremamente importante reunir mais informa ções de inclusões cujos diamantes sejam provenientes de fontes bem definidas, kimberliticas ou secundärias. Pretende-se, com isso, obter dados estatísticos relativos à frequëncia das inclu sões, e correlacionä-los com seus correspondentes minerais de xenōititos de kimberlitos. Espera-se que trabalhos desse tipo possam contribuir significativamente para ampliar o conhecimento da mineralogia do manto superior. A abundäncia de clinopiroxê nios em diamantes do kimberlito Premier na Africa do Sul, ao la do da extrema raridade desse mesmo mineral em diamantes brasile $i$ ros, constitui um bom exemplo da importancia desses estudos. No momento, esse fato não pode ser devidamente interpretado pois os resultados conhecidos não possuem significado estatístico.

Outro aspecto pouco esclarecido refere-se às possiveis inclusões fluidas cuja ocorrência no diamante vēm sendo menciona da na literatura desde o século passado (BOEWSTER, 1835; BAUER, 1904 ; EPPLER, 1961). MELTON e GIARDINI (1972, 1974, 1975), de terminaram por meio de espectrometria de massa uma sērie de com postos gasosos que, segundo esses autores, teriam sido liberta dos do diamante apōs sua fragmentação no vācuo. Apesar de todo rigor analitico com que MELTON e GIARDINI conduziram suas expe 
riēncias, o fato è que eles não levaram em conta a possibilidade de haver inclusões cristalinas nas amostras por eles estudadas. Tais inclusões poderiam, eventualmente, ser a fonte dos gases detectados de modo que a questão do diamante conter ou não in clusões fluidas continua aberta.

Outras feições pouco exploradas incluem materiais po 1 icristalinos observados por GNEVUSEV e NIKOLAEVA (1961) e HARRIS (1968), bem como os intercrescimentos cristalinos diamante-diop sídio, diamante-cromioespinëlio e diamante-rutilo descritos por FUTERGENDLER (1965) e SOBOLEV (1974) cuja origem e significado são tambëm desconhecidos. Outros trabalhos que certamente serão desenvolvidos no futuro dizem respeito a determinações isotōpicas e sinteses de inclusões.

\section{CARACTERISTICAS GERAIS DAS INCLUSÕES CRISTALINAS}

A ocorrēncia de inclusões singenēticas dentro do dia mante, ao que tudo indica, constitui um fato relativamente có mum, embora dificil de ser observado. Após termos examinado mi Thares e milhares de amostras, estimamos que a frequencia desses minerais deve oscilar em torno de $20 \%$. Aparentemente, não pare ce haver nenhuma relação entre a presença de inclusão e o tipo de hospedeiro, de tal forma que teoricamente qualquer diamante pode conter inclusões.

0 nümero de individuos cristalinos inclusos em um ün co diamante ē variāvel, mas em geral não uitrapassa de seis. Con tudo, em uma das amostras por nös estudada, conseguimos contar um total de 32 inclusões: E preciso não esquecer que esses nüme ros poderão ser majores se levarmos em conta as inclusões submi croscōpicas. Quanto ã abundäncia relativa, a olivina $\vec{e}$ de longe a inclusäo mais frequente. Seguem à olivina, as granadas, os ortopiroxēnios, a pirrotita e o prōprio diamante que foram obser vados em numerosas amostras. As demais inclusões são pouco fré quentes ou raras. 
Com relação às dimensöes, as inclusões se concentram no intervalo 100-800 mícrons. Excepcionalmente, elas podem ser observadas à vista desarmada, e nesse caso, dão a impressão de se tratar de bolhas de ar dentro do diamante. Um dos aspectos mais notāveis $\vec{e}$ o idiomorfismo acentuado de todas as inclusöes singenēticas (Fotomicrografias 1 e 2). As epigenëticas, pelo conträ rio, são irregulares, fragmentadas, e sem padrão morfolögico de finido (Micrografia eletrōnica 20). A cor é mais ou menos cá racteristica e pode auxiliar a identificação de algumas espe cies como granadas e diopsidios.

Não poderíamos deixar de ressaltar o caräter monomine rälico das inclusões estudadas. Durante todo o trabalho, não observamos um ünico caso sequer de associação poliminerälica, is to $\bar{e}$, duas ou mais fases contíguas no mesmo diamante. Trata-se de um acontecimento raro, e os unicos exemplos conhecidos são aqueles relatados por PRINZ et az. (1975) e MEYER e TSAI (1976). o que parece ser relativamente comum, $\bar{e}$ a associação de duas ou mais especcies minerais no mesmo diamante, porēm separadas entre si, tais como as que observamos entre olivina e enstatita, oli vina e granada, olivina e cromita, olivina e pirrotita e entre enstatita e granada. Associaçöes ternärias são menos frequen tes, porëm variäveis podendo reunir olivina, granada e cromió diopsidio (SOBOLEV et al. (1970); enstatita, granada e diops dio (PRINZ et $\alpha$., 1975); olivina, piropo e enstatita (MEYER é TSAI, 1976) e assim por diante.

Outro aspecto interessante são os intercrescimentos epitaxicos entre as inclusöes e seus respectivos hospedeiros. Teoricamente, o diamante pode constituir epitaxia com qualquer uma das espēcies que ele engloba; contudo, os casos descritos na literatura referem-se apenas aos intercrescimentos diamante-oli vina, diamante-cromioespinelio e diamante-piropo (FUTERGENDLER e FRANK-KAMENTSKY, 1961; HARRIS, 1966). E possivel que a ep $\underline{j}$ taxia seja um fenómeno muito mais comum do que se imagina,e que ela tenha um papel destacado no crescimento do pröprio diaman 


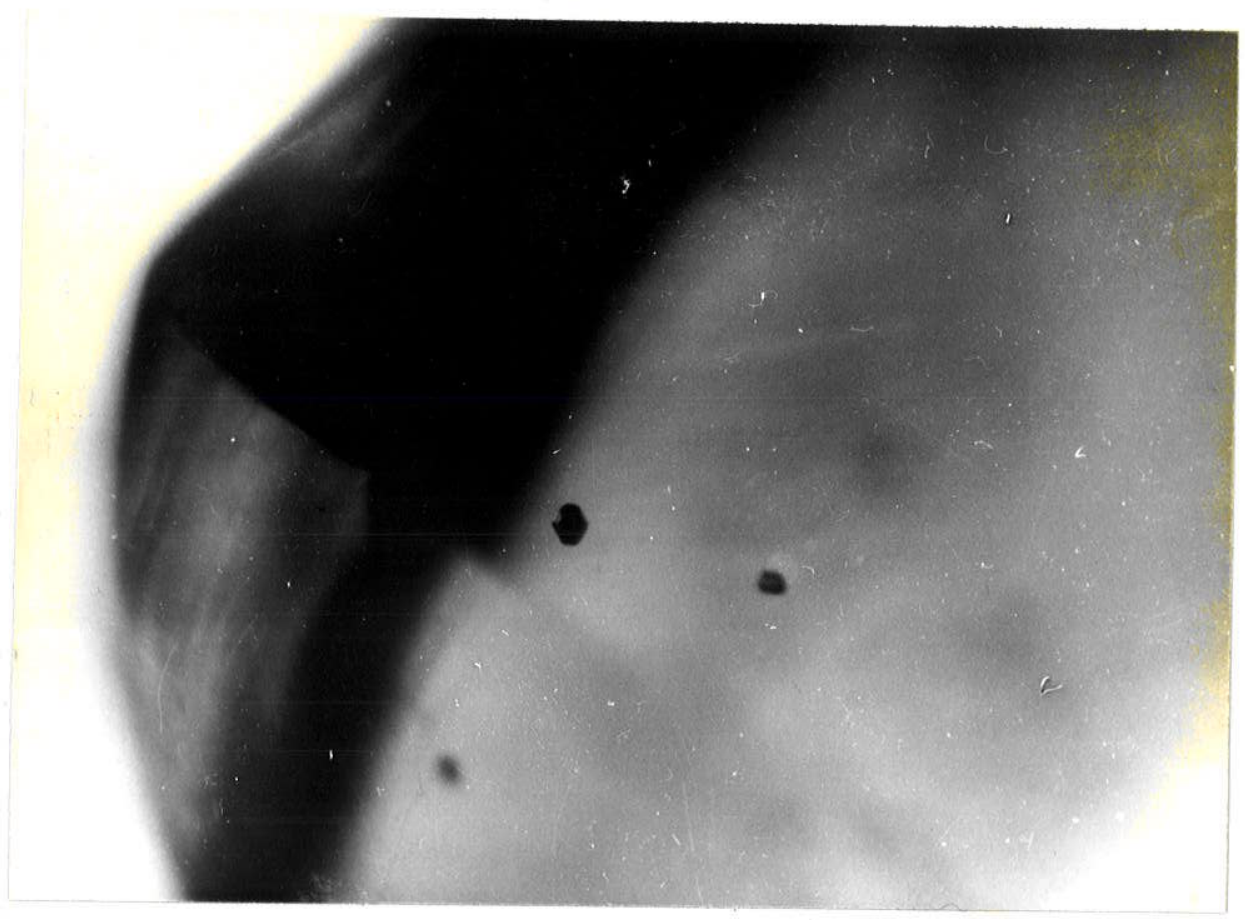

Fotomicrografia 1 - Inclusões idiomorfas situadas em níveis dife rentes no interior do hospedeiro. Observase,em primeiro plano, uma cromiopiropo de hábi to globular; em segundo plano, dois cristais prismáticos de olivina ligeiramente desfocalizados. Nícois paralelos, $20 \times$.

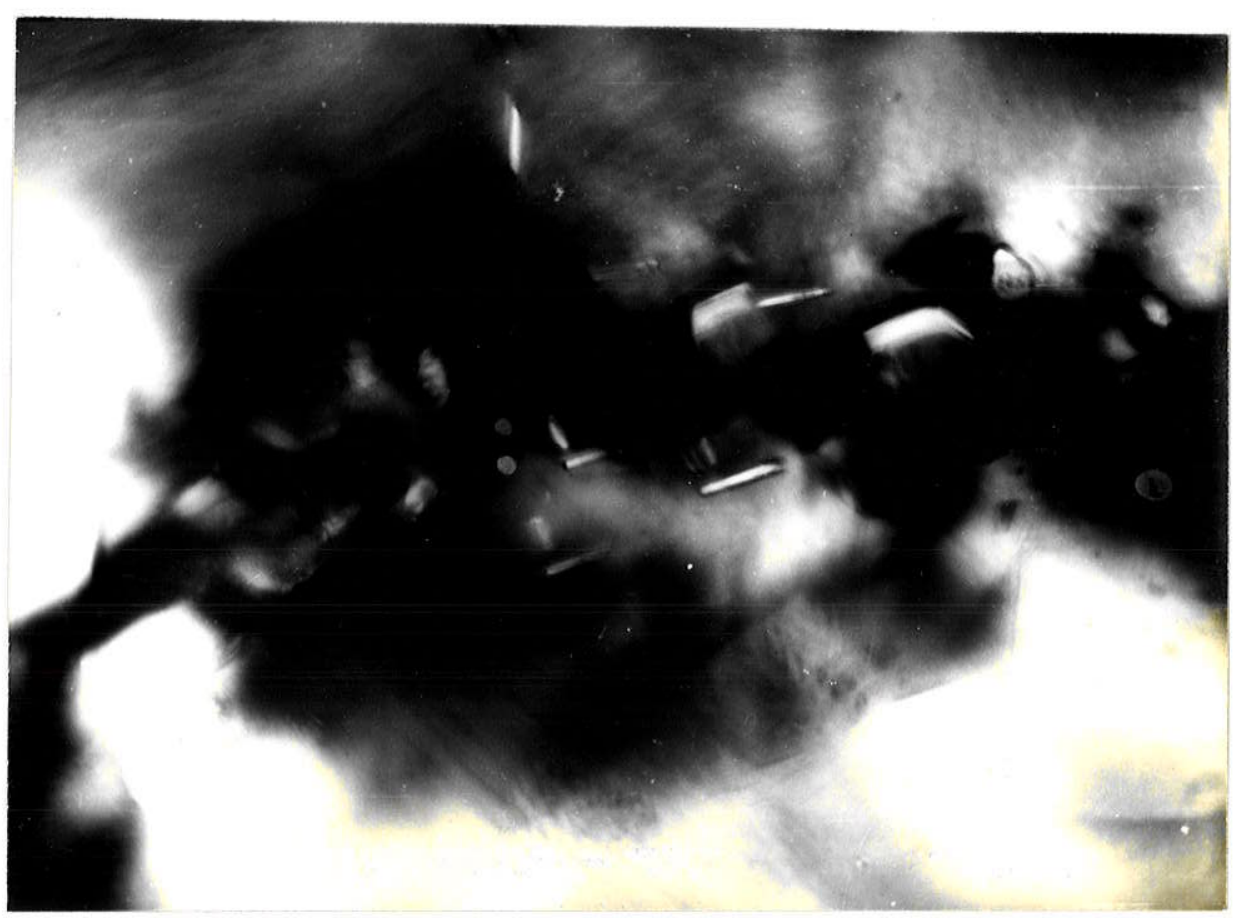

Fotomicrografia 2 - Enxame de inclusões de hábitos e dimensões variadas, parcialmente recobertas por hipérbo Les anômalas do diamante. E nítido o paralelis mo entre a maior parte dos cristais, principal mente entre os de hábito prismático. Nícois iruzados, $50 \times$. 
te. Infelizmente, os dados existentes são escassos e insuficien tes para permitir uma anālise mais profunda do seu significado genētico.

Embora o diamante cristalize na classe m3m do sistema cübico, seu comportamento entre nīcois cruzados ē totalmente anō ma 10 produzindo hipērboles irregulares, luminosidades e cores de interferēncia variäveis. Esses aspectos concentram-se em torno das inclusões, particularmente em torno das maiores que podem ser vistas facilmente ä lupa binocular ou ao microscōpio öptico. Se considerarmos a possibilidade das inclusões submicroscópicas serem realmente tão comuns como imaginam certos autores (FESQ et al., 1975), terīamos então uma explicação simples para a birre fringēncia anōmala do diamante. Diga-se de passagem que durante - nosso trabalho, muitas das inclusões, especialmente aquelas de dimensōes menores, foram localizadas por meio dos seus contornos birregringentes.

Mencione-se, ainda, outra feição comum, observävel tam bëm ao microscōpio que é a existēncia de pequenĩssimas clivagens internas radiais no espaço que circunda as inclusões. Conforme HARRIS et al. (1970) demonstraram, sua origem estā relacionada aos esforços mecãnicos resultantes da dilatação diferencial dos cristais inclusos dentro do diamante. Do ponto de vista quimico, as inclusões são absolutamente homogêneas e completamente isen tas de zoneamentos. 


\section{INCLUSÕES SINGENËTICAS}

São aquelas cuja cristalização se processa simultanea mente com o diamante hospedeiro. Nessas condições, elas possuem um interesse geolögico especial, motivo pelo qual serão abordadas pormenorizadamente nos capitulos subsequentes.

OLIVINA

E a inclusão mais comum em diamantes brasileiros ocor rendo na forma de cristais isolados ou agrupados em pequenos en xames. Normalmente constitui associações com outros minerais, só bretudo com granada, cromita e enstatita. A cor das olivinas va ria de incolor a verde bem claro, tornando-se mais acentuada apös

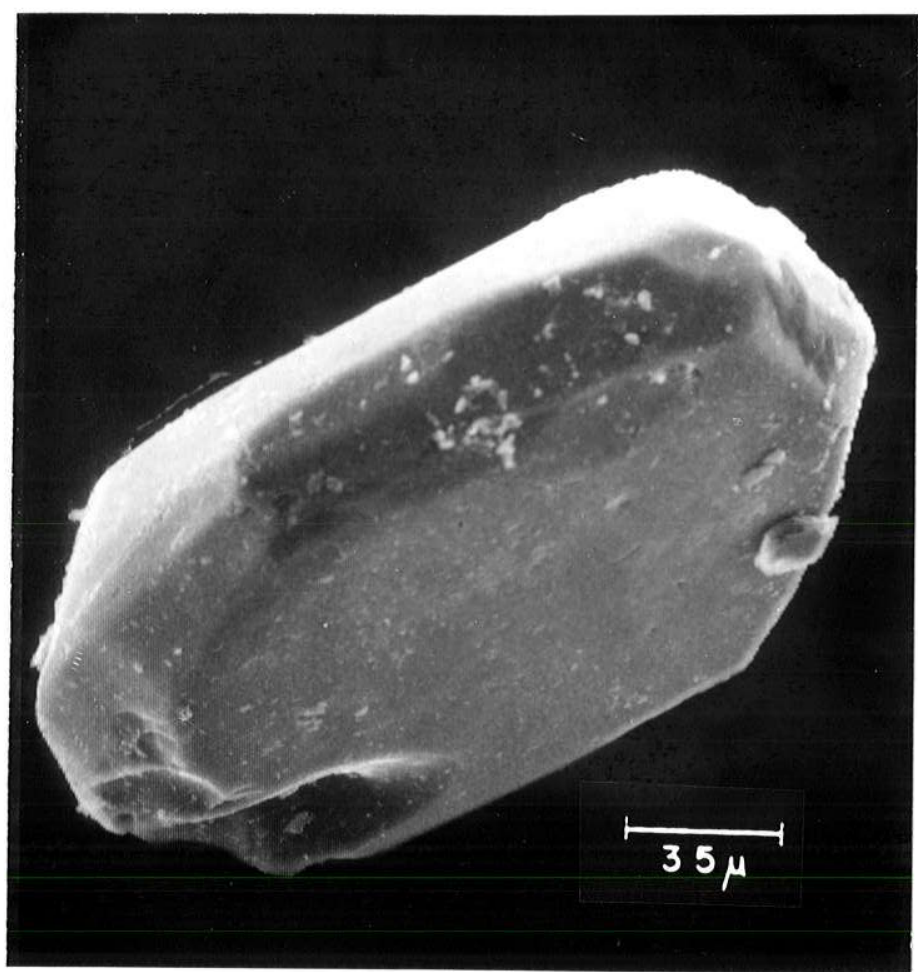

Micrografia eletrônica l - Olivina prismática contendo várias ca vidades na superfície. Aumento $450 \times$. 
ser removida do interior do hospedeiro.

Dentro do diamante, a olivina apresenta-se circundada por uma faixa escura resultante da grande diferença entre seus indices de refração $(\beta=1,65)$ e o indice do diamante $(N=2,42)$. observadas à vista desarmada, elas dão a impressão de bolhas de ar dentro do diamante, sendo essa a origem do termo tão conheci do e usado no comércio de brilhantes.

As olivinas, como as demais inclusões, são perfeita mente idiomorfas. 0 hábito varia entre prismātico (Micrografia eletrônica 1), tabular, e globular (Micrografia eletrōnica 3) sendo frequentes os individuos cristalinos em forma de gota (Mi crografia eletrōnica 5). Outro aspecto morfológico que chama nossa atenção rão só para as olivinas, mas tambēm para as de mais inclusões, é o ligeiro abaulamento das faces e arestas dos cristais. Trata-se de uma feição exibida tambēm pelo próprio diamante, e que de acordo com vārios pesquisadores seria resul tante de processos naturais de corrosão (SVISEŔ et al., 1970; WHITELOCK, 1973). Como as inclusões estão diretamente relacio nadas ao diamante, ē provāvel que elas estejam tambēm sujeitas às mesmas vicissitudes experimentadas pelo seu hospedeiro. Nes sas condições, ē bem provāvel que o abaulamento das inclusões sé ja produzido por dissolução em uma fase pretérita, antes delas serem englobadas pelo diamante.

A Micrografia eletrônica 1 mostra, de forma bem nitti da, duas depressões elîpticas e paralelas na extremidade infé rior, uma das quais estā ampliada na micrografia seguinte. Essa mesma microestrutura aparece tambëm na olivina da Micrografia eletrōnica 4, e como serā visto mais adiante, em vārias outras inclusões. 0 padrão perfeitamente regular e constante, a ausên cia de fraturas prōximas e a ocorrência generalizada dessas dé pressões, sugere que elas sejam uma feição primária das inclu u sões. Sua forma sugere antigas bolhas produzidas pelo escape de gases; isso, evidentemente, durante a fase ígnea de cristali zação das inclusões e do diamante. Essa hipátese poderia inclú 


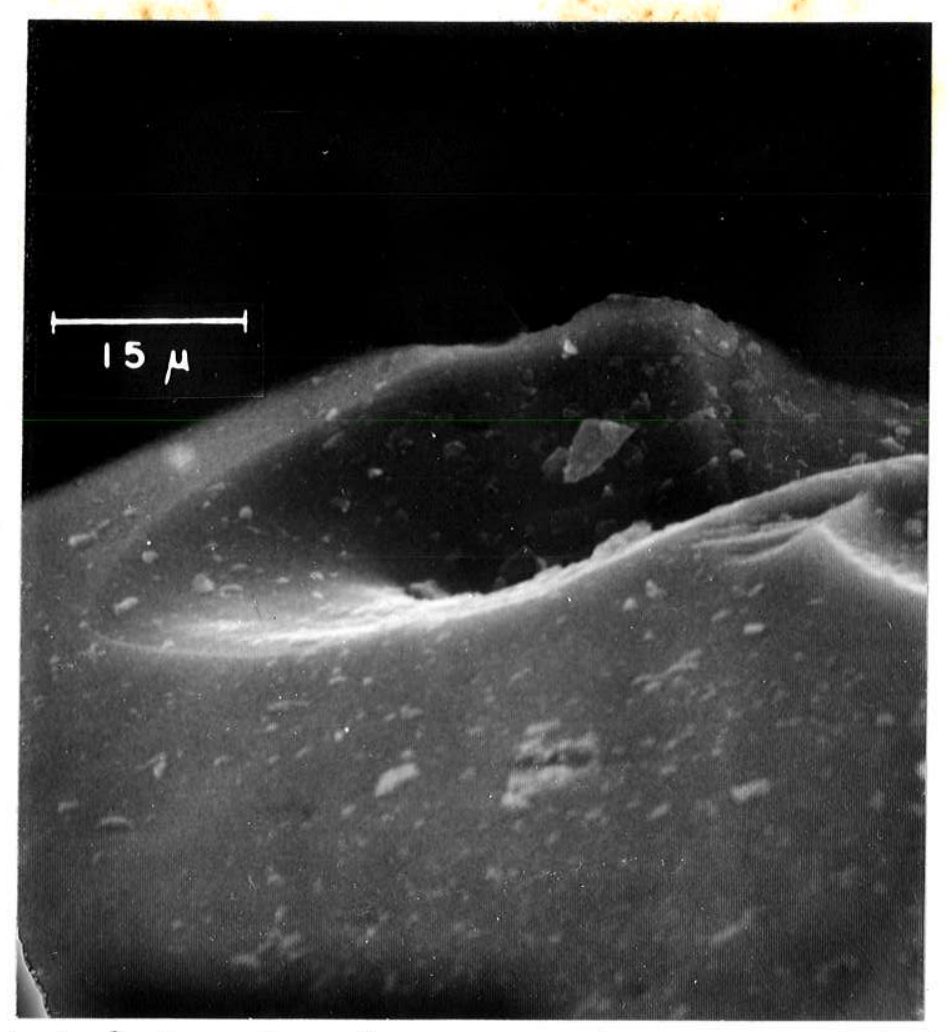

Mícografia aletrônica 2 - Pormenor de uma cavidade elipsafdica da micrografía eletrônica 1. Aumento $1.300 \times$.

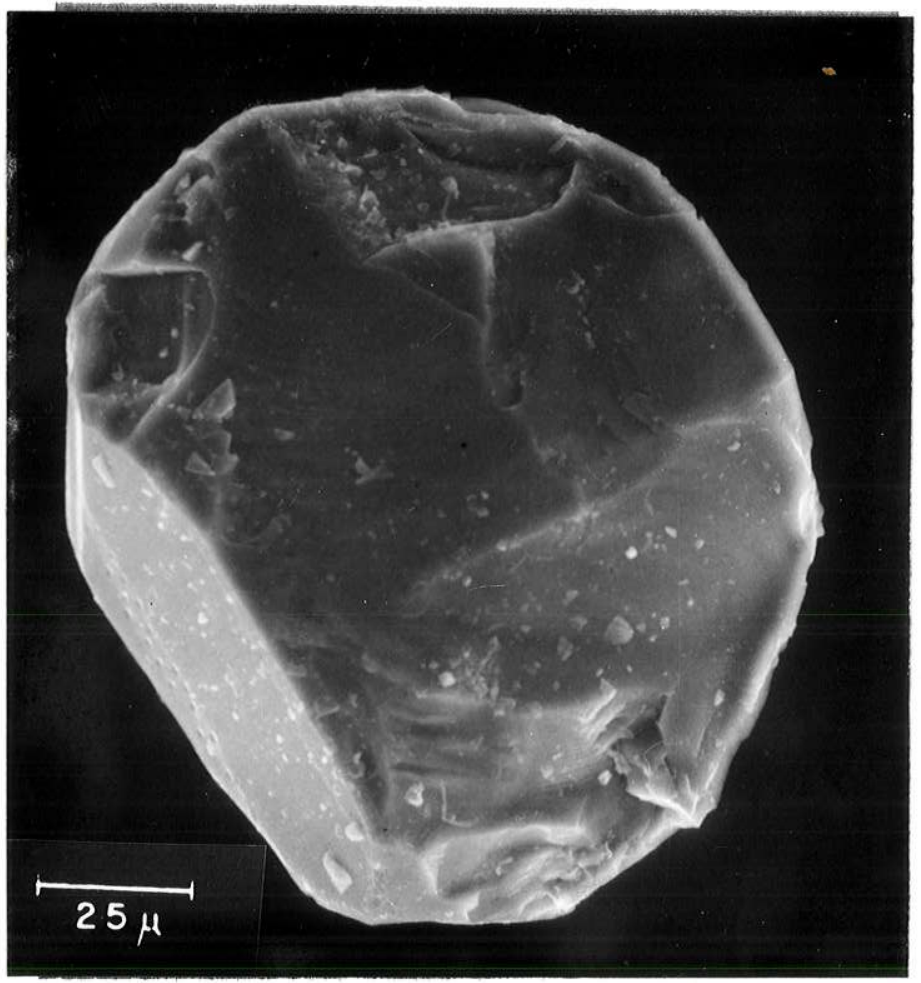

Mícrografta alotrônica 3 - Inclugão do olivina do farma globular. Aumento $600 \times$. 


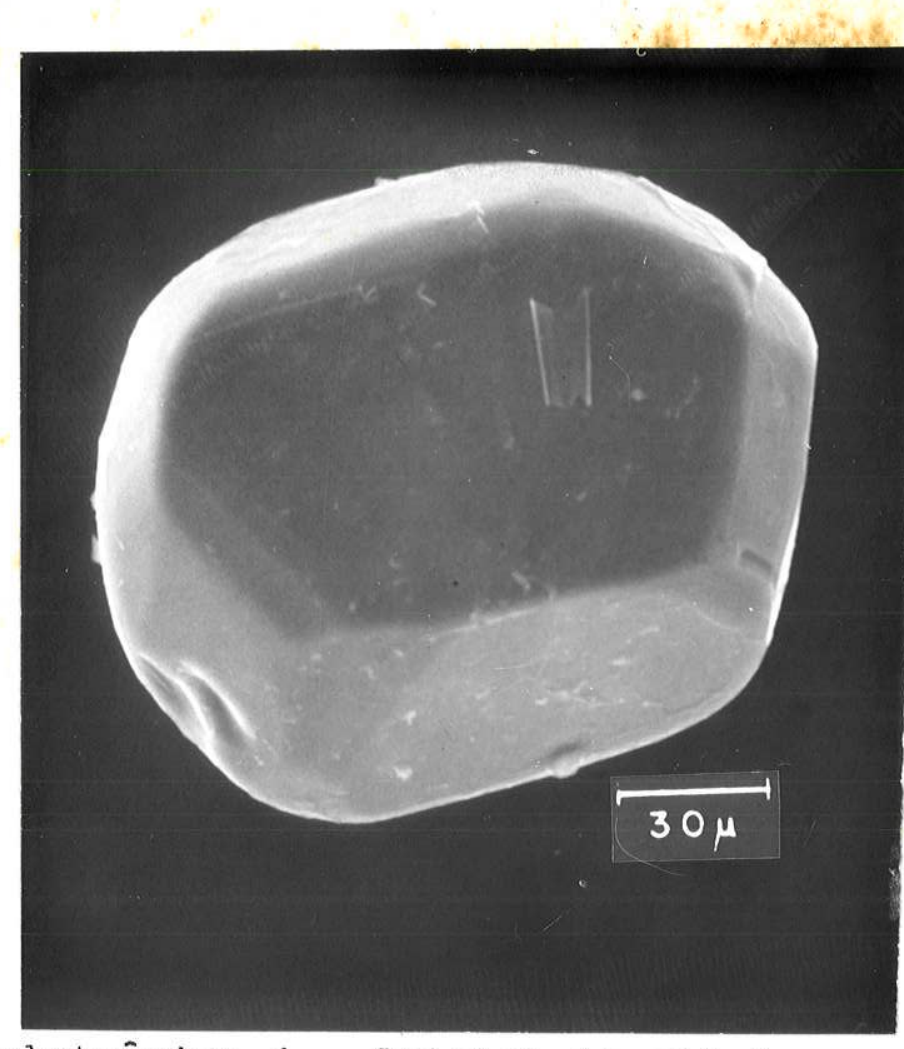

Micrografia eletrônica 4 - Cristal de olivina equidimensional com duas cavidades paralelas. Aumento $500 \mathrm{x}$.

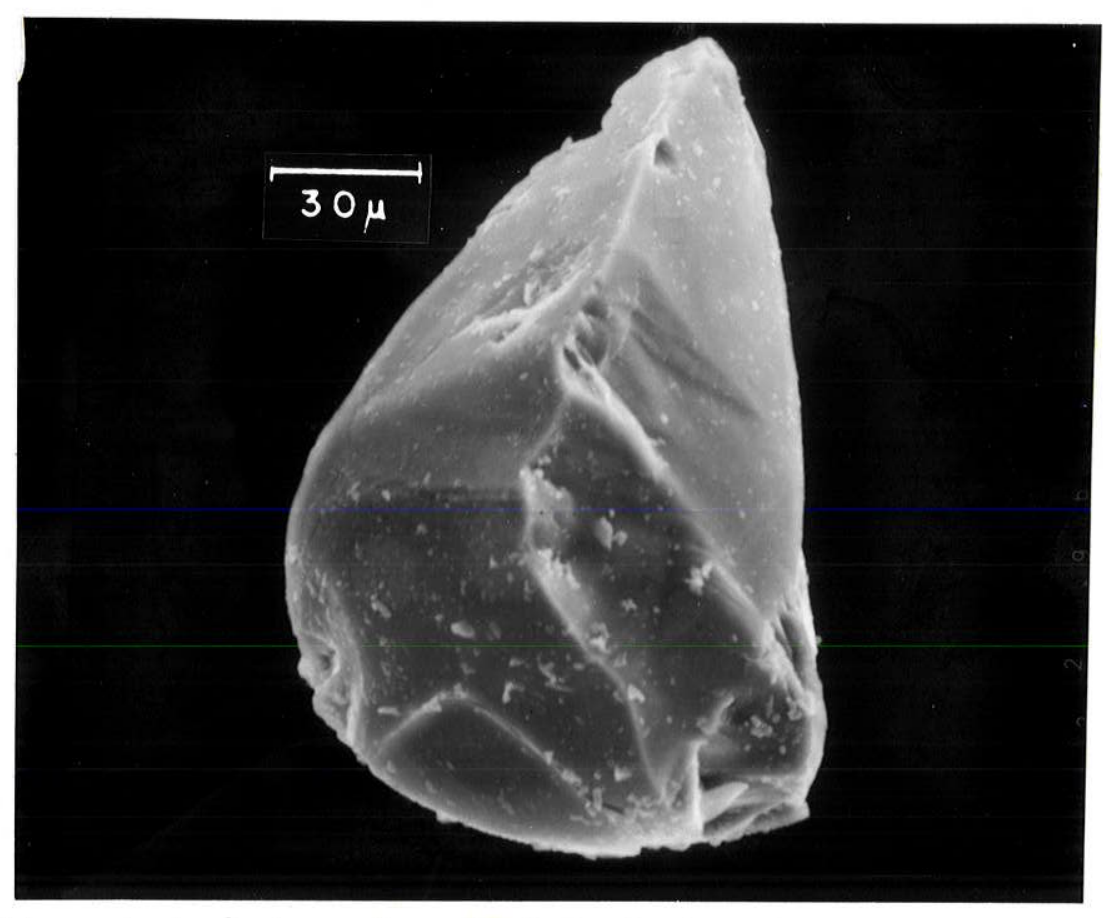

Micrografia eletrônica 5 - Cristal de olivina em forma de gota. Aumento $500 \times$. 
sive explicar a fonte dos compostos gasosos encontrados por MEL TON e GIARDINI (1972, 1974) ao fragmentarem diamantes no väcuo. Como se recorda, esses dois pesquisadores, ao identificarem a ex tensa lista de substāncias gasosas em diamantes brasileiros e africanos, não fizeram a distinção se os referidos compostos pro vinham do diamante ou de suas inclusões. Acreditamos que os ga ses referidos por MELTON e GIARDINI provenham na realidade das inclusões e que seu escape dê origem a essas interessantes de pressões superficiais.

As inclusões de olivina em geral são epitäxicas com 0 diamante. Conforme MITCHELL e GIARDINI (1953) e HARRIS et az. (1967) demonstraram, a orientação mais frequente è aquela em que o plano (010) da olivina é paralelo ao plano (111) do hospedeiro. Esse intercrescimento pode ser identificado rapidamente ao micros cöpio observando-se o diamante apoiado em uma das suas faces oc taēdricas. As inclusões de olivina, que em geral são tabulares devido ao maior desenvolvimento das suas faces (010), surgem fa cilmente no campo exatamente por apresentarem a face mais desen volvida paralela à face octaëdrica do diamante.

Examinadas ao microscōpio polarizador, as inclusões de olivina exibem cores de interferência de intensidade mëdia e ex tinção reta (Fotomicrografia 3). Quando ainda no interior dos seus hospedeiros, apresentam-se circundadas por zonas anōmalas de birrefringēncia, o mesmo ocorrendo com as demais inclusões. As demais propriedades ōpticas não puderam ser devidamente examina das em virtude das dimensões exïguas dos cristais.

A Tabela 3 apresenta onze anāilises quỉmicas quantitatí vas de inclusões de olivinas obtidas por meio da microssonda ele trōnica. Os diamantes portadores das referidas inclusões são to dos de origem detrîtica e provēm dos principais garimpos dos Es tados da Bahia, Paranā, Minas Gerais, Mato Grosso, Goiās, São Pau 10 e Territōrio de Rondōnia. Outros pormenores referentes à 10 calização dessas amostras acham-se na Tabela 1. Examinando-se a Tabela 3 , observamos que as olivinas analisadas apresentam compo 


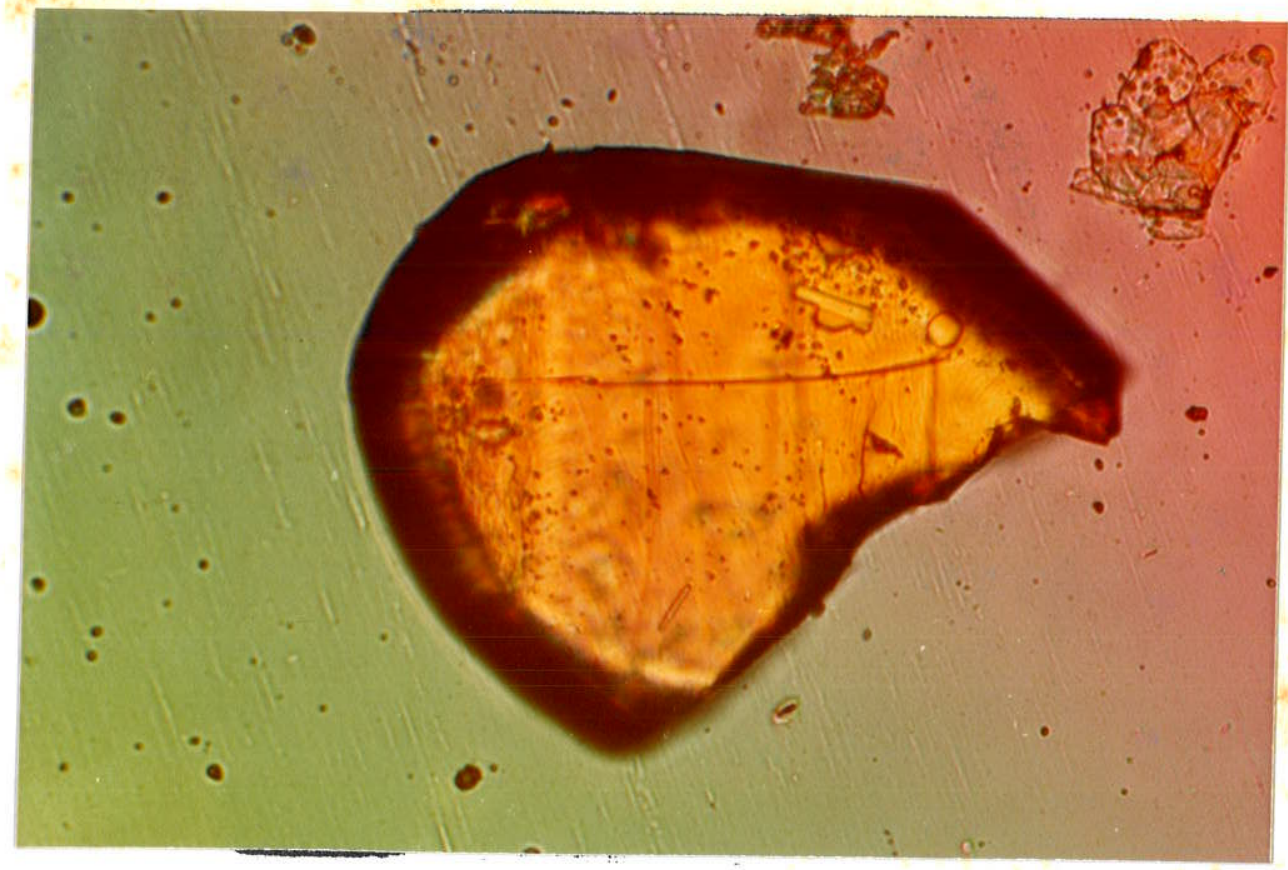

Fotomicrografia 3 - Olivina de hábito tabular, fraturada durante a remoção do hopedeiro. Nícois cruzados, $30 \times$

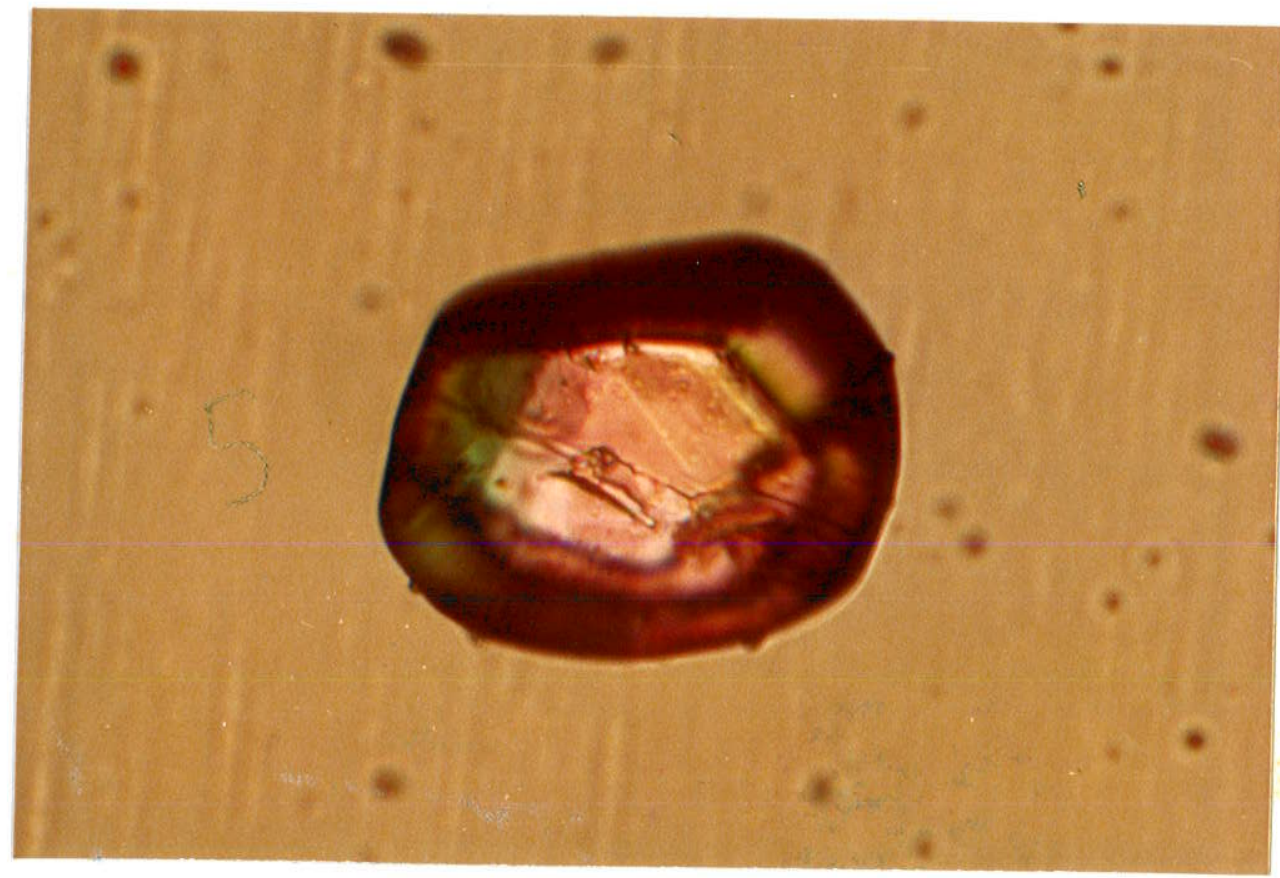

Fotomicrografia 4 - Enstatita de häbito prismático, biterminada. Nícois cruzados, $40 x$. 
sições quimicas quase constantes, havendo pequena variação entre seus elementos quimicos principais subordinados. Esse fato ë al tamente significativo, mormente se levarmos em conta as distān cias que separam as amostras entre si.

Embora os minerais do grupo das olivinas variem ampla mente em seus teores de magnēsio e ferro, as olivinas associadas ao diamante parecem mostrar uma variação restrita em relação a esses elementos. De fato, os conteūdos de $\mathrm{Mg}_{2} \mathrm{SiO}_{4}$ calculados a partir dos dados constantes da Tabela 3 mostram, perfeitamente, que todas as olivinas estudadas são magnesianas e correspondem ao termo forsterita da sērie forsterita-fayalita (Tabela 4).

A Figura 4 mostra uma sērie de histogramas construi dos para comparar a variação da razão $\mathrm{Mg} \times 100 / \mathrm{Mg}+\mathrm{Fe}$ entre as inclusões de olivinas estudadas e olivinas de outras associações ultramáficas e ultrabäsicas diversas. 0 primeiro deles (4a) re fere-se às inclusões analisadas neste trabalho cujas razões $\mathrm{Mg}$ $x 100 / \mathrm{Mg}+\mathrm{Fe}$ se restringem ao intervalo $92-95 \%$, com uma concen tração acentuada em torno de 92 e $93 \%$. 0 histograma seguinte (4b) reune dados de inclusões proveniente das mais importantes regiões diamantîferas do mundo, a saber, Africa do Sul, Gana, Ser ra Leoa, e Tailāndia (MEYER e BOYD, 1972), Venezuela (SVISERO e GOMES, 1977), e União Soviētica (SOBOLEV et al., 1970; SOBOLEV, 1974). Embora a variação șeja ligeiramente maior devido ao maior nümero de dados disponīveis, a moda do histograma $\bar{e}$ quase coin cidente com a referente ao material do Brasil. 0 terceiro grä fico (4c) refere-se a olivinas de kimberlitos (MCGETCHIN e SIL VER, 1970; MITCHELL e FRITZ, 1973; CLARKE e MITCHELL, 1975; BOYD e CLEMENT, 1977). Nesse caso, a variação da razão $\mathrm{Mg} \times 100 / \mathrm{Mg}+$ + Fe cobre um intervalo bem maior do que o mostrado pelas inclu söes, e possui diversas modas das quais a mais importante se 10 caliza ao redor de $90 \%$. Finalmente, o ültimo histograma reune olivinas de xenölitos de lherzolitos granulares e estria dos de kimberlitos (BOYD e NIXON, 1973; NIXON e BOYD, 1973; BLOOMER e NIXON, 1973; BOYD, 1974a). Tambēm nesse caso, a varia 
TABELA 3 - COMPOSIÇAO QUTMICA DE IRCLUSOES DE OLIVIMA PRESENTES EM DIAMANTES DO BRASIL

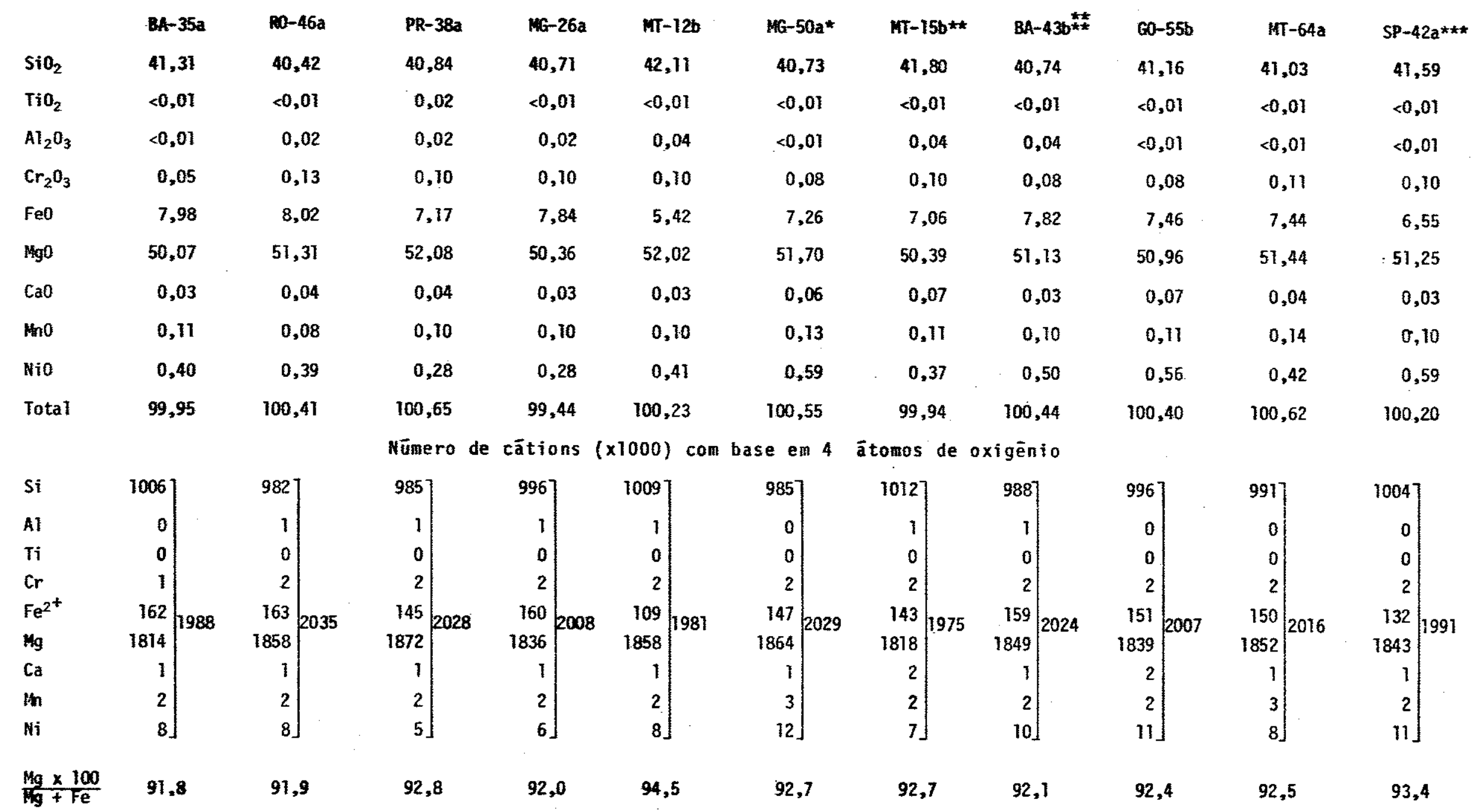

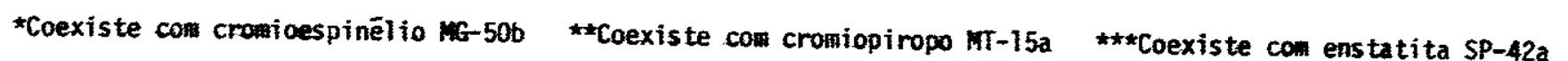


TABELA 4 - PORCENTAGENS DAS MOLECULAS CONSTITUINTES DAS OLIVINAS INCLUSAS EM DIAMANTES BRASILEIROS

\begin{tabular}{|c|c|c|c|c|c|c|c|}
\hline AMOSTRA & $\mathrm{Cr}_{2} \mathrm{SiO}_{4}$ & $\begin{array}{l}\mathrm{Ca}_{2} \mathrm{SiO}_{4} \\
\text { Larnita }\end{array}$ & $\begin{array}{l}\mathrm{Mn}_{2} \mathrm{SiO}_{4} \\
\text { Tefroita }\end{array}$ & $\mathrm{Ni}_{2} \mathrm{SiO}_{4}$ & $\begin{array}{l}\mathrm{Fe}_{2} \mathrm{SiO}_{4} \\
\text { Fayalita }\end{array}$ & $\begin{array}{l}\mathrm{Mg}_{2} \mathrm{SiO}_{4} \\
\text { Forsterita }\end{array}$ & Total \\
\hline$B A-35 a$ & 0,04 & 0,04 & 0,11 & 0,40 & 8,06 & 91,35 & 100,04 \\
\hline $\mathrm{RO}-46 \mathrm{a}$ & 0,07 & 0,07 & 0,07 & 0,37 & 7,86 & 91,55 & 99,99 \\
\hline PR-38a & 0,04 & 0,07 & 0,11 & 0,29 & 7,05 & 92,44 & 100,00 \\
\hline$M G-26 a$ & 0,04 & 0,04 & 0,11 & 0,30 & 7,89 & 91,42 & 99,90 \\
\hline$M T-12 b$ & 0,04 & 0,04 & 0,10 & 0,39 & 5,34 & 94,10 & 100,01 \\
\hline$M G-50 a$ & 0,04 & 0,07 & 0,15 & 0,59 & 7,14 & 91,97 & 99,96 \\
\hline$M T-15 b$ & 0,04 & 0,07 & 0,11 & 0,36 & 7,03 & 92,39 & 100,00 \\
\hline$B A-43 b$ & 0,04 & 0,04 & 0,11 & 0,48 & 7,73 & 97,60 & 100,00 \\
\hline$G O-55 b$ & 0,04 & 0,07 & 0,11 & 0,55 & 7,51 & 91,69 & 99,47 \\
\hline$M T-64 a$ & 0,05 & 0,04 & 0,15 & 0,40 & 7,31 & 92,10 & 100,05 \\
\hline$S P-42 a$ & 0,05 & 0,04 & 0,11 & 0,58 & 6,50 & 92,40 & 99,68 \\
\hline
\end{tabular}



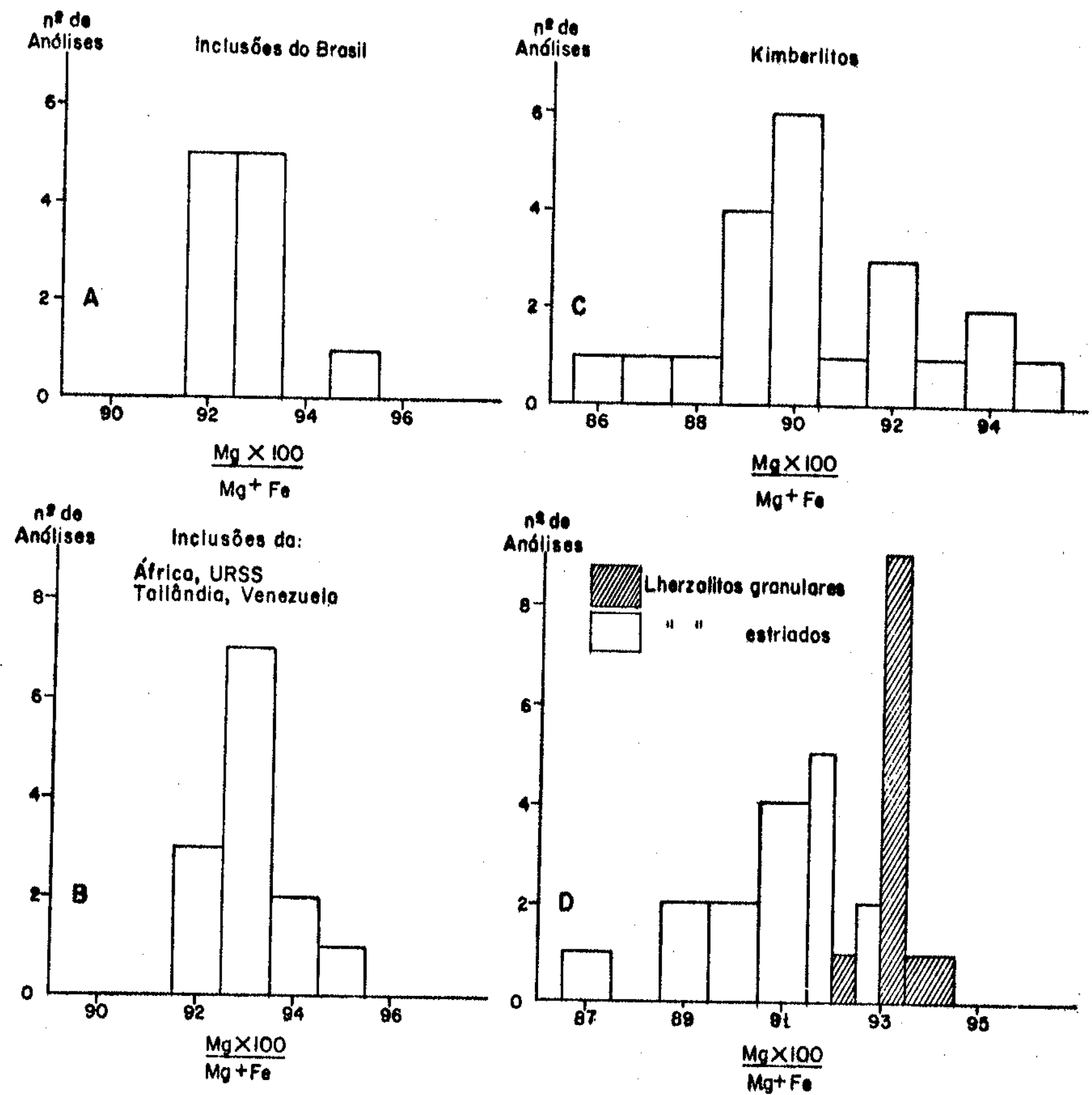

Figura 4 - Comparação das razões Mg $\times 100 / M g+F e$ de olivinas inclu sas em diamantes do Brasil (a), com olivinas associadas a diamantes de outros palses (b), olivinas de kimberlitos $(c)$, e olivinas constituintes de xenólitos de lherzolitos granulares e estriados de kimberlitos(d). Notar a semelhança entre as inclusões de diamante(a,b) com as olivinas dos xenólitos granulares(d). Dados comparativos extrafdos de MCGETCHIN a SILVER(1970), SOBOLEV etal(1971), MEYER \& BOYD (1972); BOYD \& NIXON(1973); MITCHELL FRITZ(1973); BLOOMER \& NIXON(1973); BOYO(1974); SOBOLEV (1974), CLARKE \& MITCHELL(1975); SVISERO \& GOMES(1977), BOYD CLEMENT (1977). 
ção è ampla, mas bem distinta para os dois tipos de xenōlitos.As olivinas dos xenōlitos granulares são mais magnesianas do que a dos estriados, e da mesma forma que nos kimberlitos, o histograma contēm diversas modàs.

Analisando-se todos os grāficos da Figura 4 è fäcil concluir que as inclusöes dos diamantes do Brasil e dos demais locais do mundo são quase concordantes entre si. Trata-se de um aspecto interessante pois essas amostras distam entre si vārios milhares de quilômetros. Outra conclusão genētica importante é a semelhança entre as inclusões e as olivinas constituintes dos 1herzolitos granulares de kimberlitos.

Com relação aos elementos subordinados, as olivinas presentes nos diamantes brasileiros contēm pequenas quantidades de Ti, Al, Cr, Ca, Mn e Ni (Tabela 3). Embora os teores de $\mathrm{Cr}_{2} \mathrm{O}_{3}$ sejam relativamente baixos, eles são bem maiores do que o de olivinas de outras associações ultramäficas conforme o demons tra a Figura 5. Este gräfico mostra a variação da porcentagem em peso de $\mathrm{Cr}_{2} \mathrm{O}_{3}$ em função do valor de $\mathrm{MgO}$, e reune olivinas de paragēneses diversas onde se incluem as inclusões estudadas, xe nölitos de lherzolitos granulares e estriados de kimberlitos (NIXON e BOYD, 1973; BOYD e NIXON, 1975), komatyitos (PIKE et al., 1973 ) e basaltos lunares (BUTLER, 1972).

Os teores de $\mathrm{Cr}_{2}{ }_{3}$ referentes às inclusöes se equiva lem aos das olivinas constituintes dos xenōlitos de lherzolitos estriados de kimberlitos, superando ligeiramente os teores das olivinas dos xenōilitos de lherzolitos granulares de kimberlitos. Trata-se de um aspecto curioso, pois como vimos anteriormente na Figura 4, em relação a variação da razão $\mathrm{Mg} \times 100 / \mathrm{Mg}+\mathrm{Fe}$, as in clusões se aproximam mais das olivinas dos xenōlitos granulares do que dos estriados.

Como se pode verificar pela Figura 5, o teor de $\mathrm{Cr}_{2} \mathrm{O}_{3}$ das inclusões sō ē superado pelo das olivinas spinifex das la vas komatyīticas que ocorrem associadas a complexos ultramāficos 


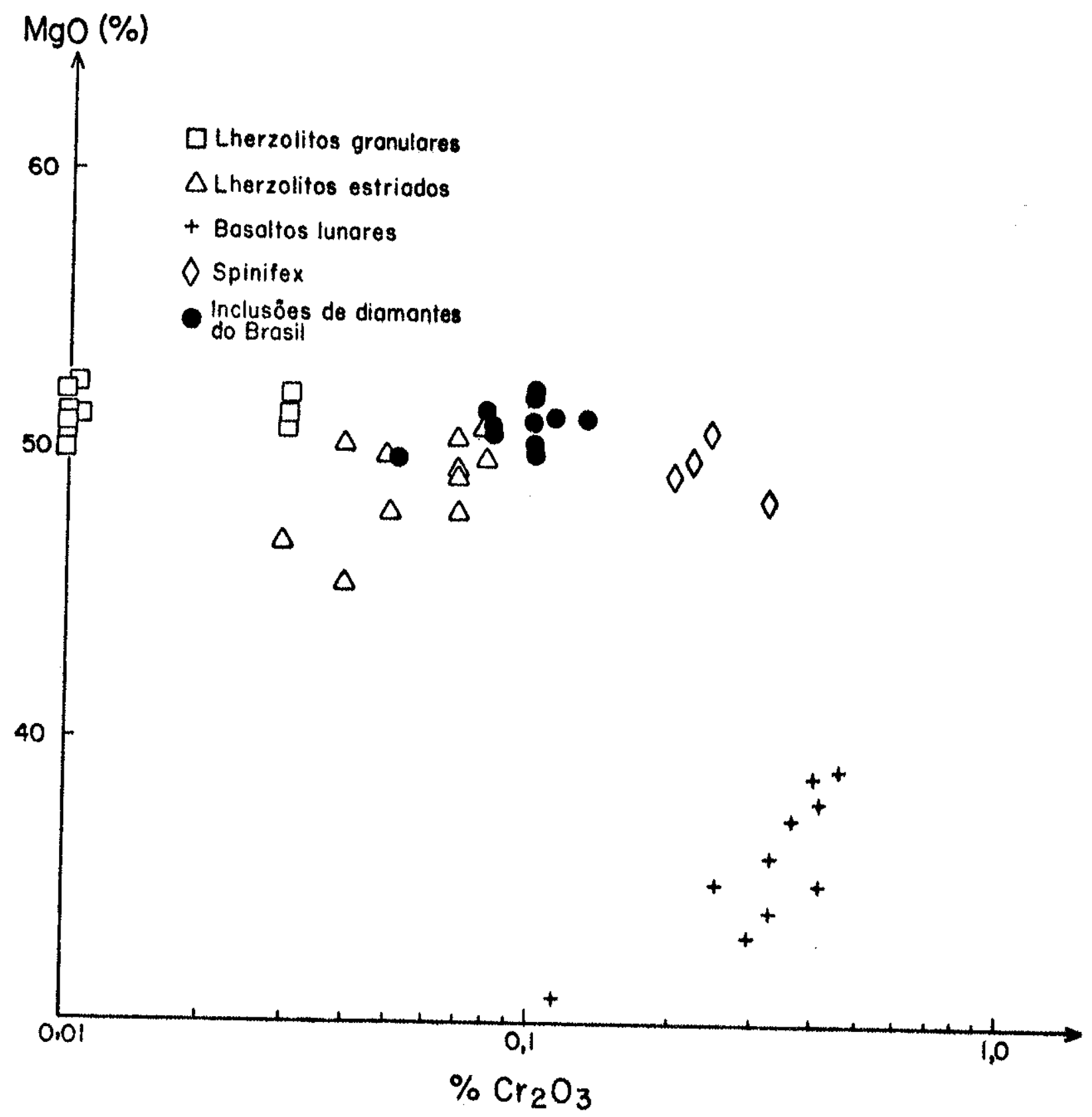

Figura 5 - Variação do teor de $\mathrm{Cr}_{2} \mathrm{O}_{3}$ em função do teor de Mgo de olivinas inclusas em diamantes do Brasil, comparadas com olivinas de outras origens. As inclusões dos diamantes brasileiros exibem teores de crómio relativamente altos pera olivinas terrestres sendo superadas apenas por ol1 vinas de komatiltos. Dados comparativos extraídos de $\overline{\text { Uu }}$ TLER (1972); PIKE et al(1973); NIXON a BOYD(1973); BOY ๑ NIXON (1975). 
arqueanos do Canadä (PIKE et al., 1973). Admite-se que ao extra vasarem na superfīcie terrestre, essas lavas alcancem temperatú ras da ordem de $1.500^{\circ} \mathrm{C}$. Durante o räpido resfriamento que sé gue, os cristais neoformados de olivinas adquirem uma textura es quelētica que lembra certas gramineas do gênero spinifex da Aus trälia, daj a origem do termo olivina spinifex. Seus teores em $\mathrm{Cr}_{2} \mathrm{O}_{3}$ são os mais altos para olivinas terrestres sendo comparä veis aos das olivinas dos basaltos lunares cujos teores podem a) cançar $0,45 \%$.

MEYER (1975) estudou exaustivamente o comportamento cristaloquímico do crōmio nas olivinas. Ele sugeiru que o crō mio presente nas inclusões estä sob a forma de $\mathrm{Cr}^{2+}$, e que sua incorporação è controlada pela fugacidade de oxigēnio. Conclusões anälogas foram apresentadas por BURNS (1975). Estendendo suas considerações às olivinas lunares, MEYER (1975) admite condições redutoras acentuadas durante a cristalização das inclusões de olivina. Essas idēias concordam perfeitamente com as conclusões de KENNEDY e NORDLIE (1968) para quem o diamante se forma na na tureza em ambiente fortemente redutor.

\section{ENSTATITA}

Atē o momento presente a enstatita $\bar{e}$ o ünico ortopiro xēnio identificado como inclusão em diamante. Em relação às de mais inclusões, a enstatita e o terceiro mineral em frequéncia, logo apōs a olivina e a granada. A cor da enstatita varia de in color a verde claro, acentuando-se quando a inclusão estä fora do hospedeiro. As inclusões de enstatita são muito semelhantes às de olivina e a distinção entre elas sō pode ser estabelecida com segurança utilizando-se difração de raios $x$, ou mediante ană lises na microssonda eletrōnica. Contudo, no decorrer deste tra balho anotamos uma sērie de particularidades que embora não te 
nham carāter absoluto, pelo menos facilitam a distinção entre es sas duas inclusões.

Durante a remoção mecânica das inclusões, ē comum as enstatitas se clivarem "(Micrografia eletrōnica 7), fato raramen te observado entre as olivinas. Outra diferença curiosa entre esses dois minerais pode ser observada durante a oxidação de a I guns diamantes à temperatura de $800^{\circ} \mathrm{C}$. Apōs a combustão do hos pedeiro, as inclusões de olivinas adquirem tonalidade vermelha clara enquanto que as enstatitas permanecem incolores. Ao que tudo indica, o ferro da estrutura da olivina è mais susceptível à oxidaçäo do que o da enstatita. Esse fato concorda com o com portamento desses dois minerais na natureza, onde a olivina é mais susceptível às alterações do que a enstatita.

0 häbito da enstatita ē predominantemente prismätico (Micrografias eletrōnicas 6 e 7), e menos variāvel do que o da olivina. Observa-se pelas micrografias referidas que a enstati ta desenvolve cristais mais proporcionados, e em geral, eles são constituīdos por um grande nümero de faces cujas formas cristalo gräficas correspondentes não puderam ser determinadas. Ao mi croscōpio ōptico, a enstatita ē absolutamente semelhante a olivi na, apresentando extinção reta e cores de interferência médias

(Fotomicrografia 4). Observações cuidadosas indicaram que todas enstatitas são isentas de pleocroismo.

As enstatitas analisadas neste trabalho, em numero de oito, estão reunidas na Tabela 5. Elas incluem amostras proce dentes dos principais garimpos de Minas Gerais, Bahia, Mato Gros so, São Paulo, e Territōrio da Rondōnia. Outros pormenores refe rentes a localização dessas amostras estão citados na Tabela 1.

Tal como nas olivinas, a composição quỉmica das enstâ titas ë pouco variävel, tanto no que diz respeito aos elementos químicos prịcipais quanto em relação aos elementos subordinados. A Tabela 6 relaciona as porcentagens das três moléculas consti tuintes principais, enstatita, ferrossilita e wollastonita, evi denciando o predominio absoluto do termo $\mathrm{MgSiO}_{3}$. 


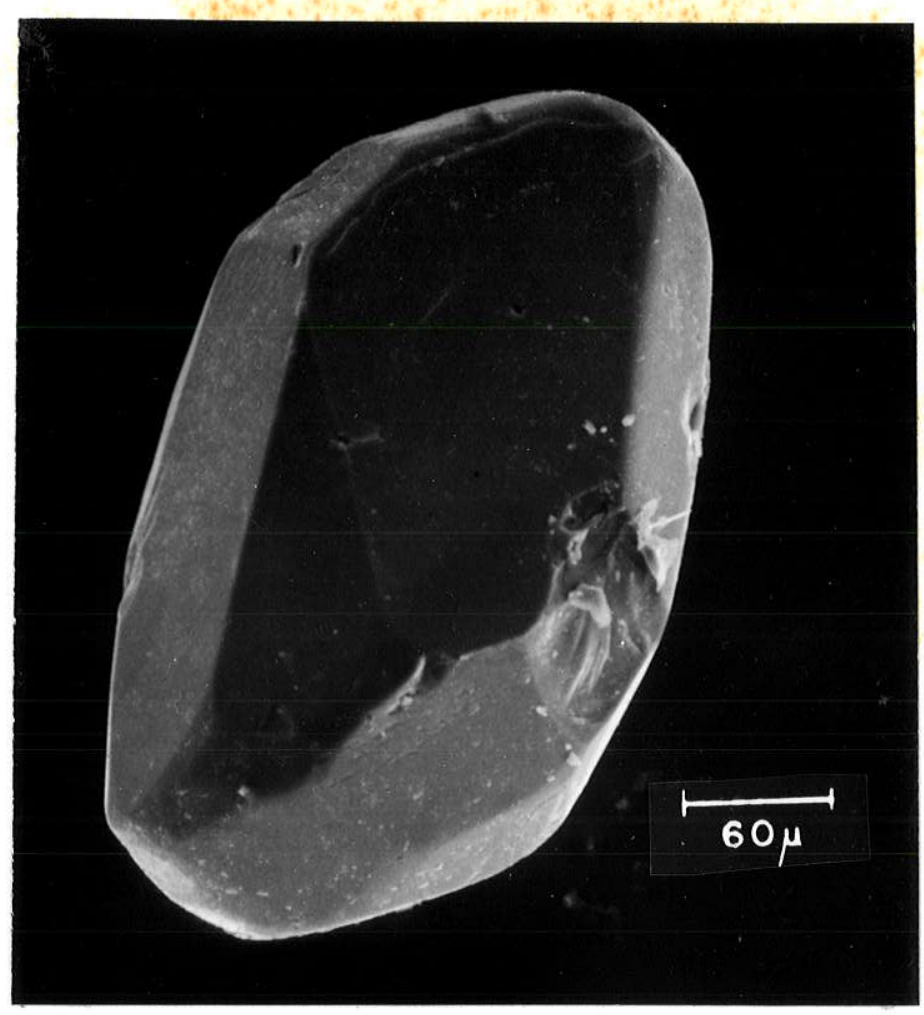

$-40=$

Micragrafia eletrônica 6 - Cristal equidimensional de enstatita. Aumento $250 \times$.

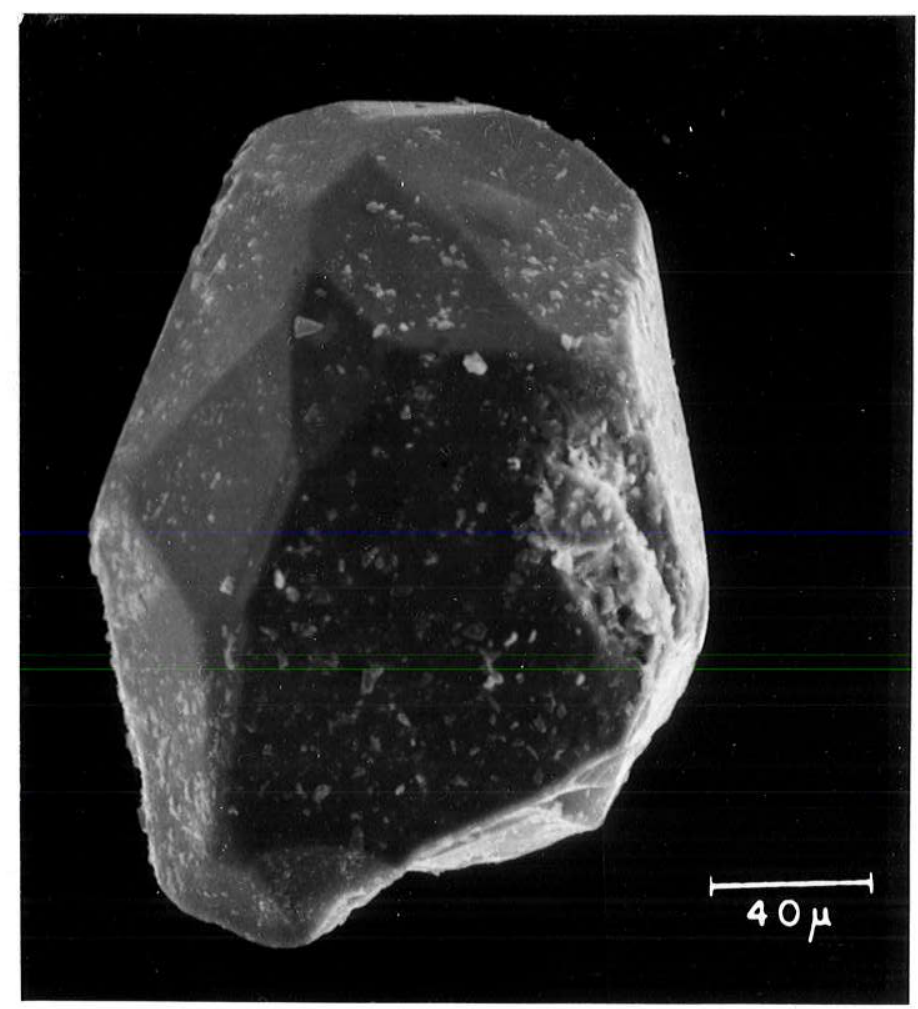

Micrografia eletrônica 7 - Cristal de enstatita apoiado sobre uma superfície de clivagem. Aumento 400 x. 
TABELA 5 - COMPOSIÇÃO QUTMICA DE INCLUSÕES DE ENSTATITA PRESENTES EM DIAMANTES DO BRASIL

$\begin{array}{rrrrrrrr}M G-34 a & R 0-2 a & G 0-55 a & \text { BA-51b } & \text { MT-48a } & \text { MG-21b* } & \text { MG-27a } & \text { SP-42b** } \\ 56,69 & 57,56 & 57,50 & 57,57 & 57,53 & 57,57 & 57,27 & 57,85 \\ <0,01 & <0,01 & <0,01 & <0,01 & <0,01 & <0,01 & <0,01 & <0,01 \\ 0,84 & 0,51 & 0,60 & 0,87 & 0,69 & 0,78 & 0,51 & 0,44 \\ 0,46 & 0,11 & 0,47 & 0,62 & 0,49 & 0,47 & 0,34 & 0,33 \\ 4,17 & 4,95 & 4,68 & 4,27 & 4,51 & 4,36 & 4,75 & 4,39 \\ 36,64 & 35,34 & 36,87 & 36,60 & 36,70 & 36,18 & 36,15 & 36,37 \\ 0,43 & 0,54 & 0,31 & 0,14 & 0,26 & 0,47 & 0,18 & 0,34 \\ 0,14 & 0,34 & 0,10 & 0,13 & 0,13 & 0,11 & 0,10 & 0,30 \\ 0,17 & 0,02 & 0,11 & 0,11 & 0,09 & <0,01 & 0,39 & 0,08 \\ 99,53 & 99,38 & 100,64 & 100,31 & 99,95 & 99,95 & 99,58 & 100,10\end{array}$

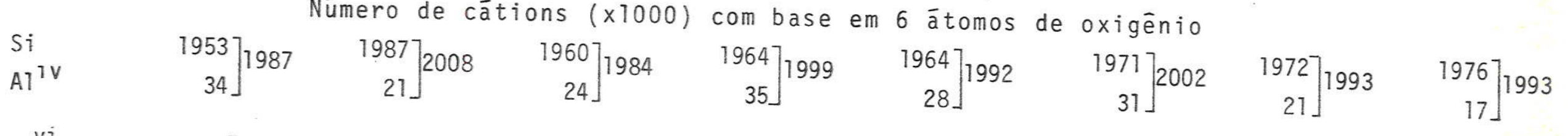

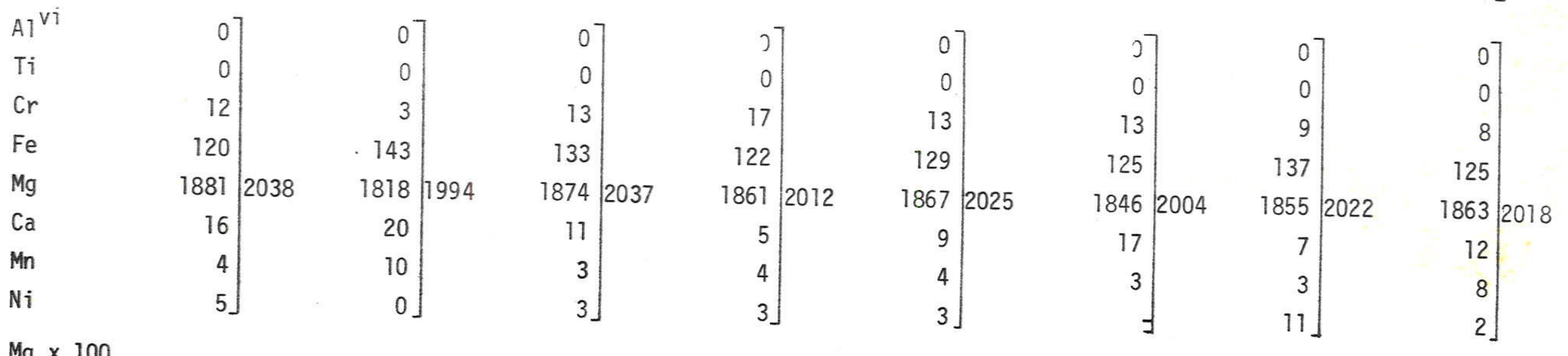

$\frac{M g \times 100}{M g+F e}$

94,0

92,7

93,4

93,8

93,5

93,6

93,1

93,8

*Coexiste com cromiopiropo MG-21a

**Coexiste com olivina SP-42a 
TABELA 6 - PORCENTAGENS DAS MOLECULAS CONSTITUINTES DAS ENSTATITAS INCLUSAS EM DIAMANTES BRASILEIROS

$\begin{array}{cccc}\mathrm{CaSiO}_{3} & \mathrm{FeSiO}_{3} & \mathrm{MgSiO}_{3} & \\ \text { Wollastonita } & \text { Ferrossilita } & \text { Enstatita } & \text { Total }\end{array}$

$\begin{array}{lllll}\text { MG-34a } & 0,84 & 5,82 & 93,33 & 99,99 \\ \text { RO-2a } & 0,94 & 7,19 & 91,86 & 99,99 \\ \text { G0-55a } & 0,52 & 6,47 & 93,00 & 99,99 \\ \text { BA-51b } & 0,21 & 6,04 & 93,75 & 100,00 \\ \text { MT-48a } & 0,42 & 6,36 & 93,51 & 100,29 \\ M G-21 b & 0,83 & 6,25 & 92,92 & 100,00 \\ M G-27 a & 0,31 & 6,70 & 92,98 & 99,99 \\ \text { SP-42b } & 0,62 & 6,32 & 93,10 & 100,04\end{array}$


0s histogramas da Figura 6 ilustram a variação da ra

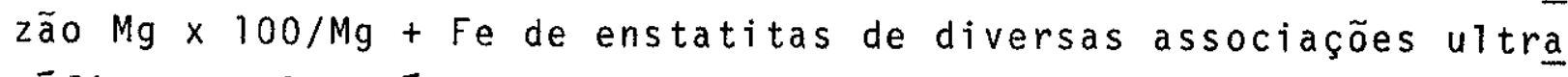
mäficas e ultrabāsicas. 0 histograma $6 a$ refere-se às inclusões estudadas e mostra que suas razões $\mathrm{Mg} \times 100 / \mathrm{Mg}+\mathrm{Fe}$ se restrịn gem ao intervalo 93-94\%. Segue-se o histograma 6 b reunindo va lores referentes a inclusões de outros países, a saber, Gana é Serra Leoa (MEYER e BOYD, 1972), Venezuela (SVISERO e GOMES, 1977), Tanzānia e Africa do Sul (MEYER e TSAI, 1976) e União Soviētica (SOBOLEV et al., 1971a; SOBOLEV, 1974). A variação dessas inclu sões coincide exatamente com a do material brasileiro, inclusive a moda cujo valor $\bar{e} 94 \%$. A ünica exceção refere-se a uma amos tra descrita por PRINZ et al. (1975), cujo valor igual a $86 \%$ é demasiado baixo para inclusão em diamante, razão pela qual prefe rimos omitī-la do histograma 6b. Aliās, os prōprios autores ale gam ter retirado a inclusäo de um diamante fraturado, o que au menta ainda mais a dūvida sobre a natureza singenētica desta in clusão. O histograma seguinte (6c) contëm enstatitas de kimber 1 itos (McGETCHIM e SILVER, 1970; ROLFE, 1973; SOBOLEV, 1974), cuja variaçäo relativamente à razão $\mathrm{Mg} \times 100 / \mathrm{Mg}+\mathrm{Fe}$ abrange o inter valo de 91 a $94 \%$, sendo ligeiramente maior do que a das inclusões. 0 histograma $6 \mathrm{~d}$ relaciona dados referentes a xenōitos de 1 herzo litos granulares e estriados de kimberlitos (NIXON e BOYD, 1973; BLOOMER e NIXON, 1973; BOYD, 1974b; BOYD e NIXON, 1975). Nesse caso, a variação e bem mais ampla, estendendo-se de 89 a $94 \%$, po rēm bem distinta para os dois tipos de xenōlitos.

A anāise conjunta de todos histogramas reforça as con clusões jā obtidas anteriormente com as olivinas e que são: 1) semelhança perfeita entre as inclusões de enstatita do Brasil com as inclusões de outros locais geogräficos do mundo; 2) semelhança acentuada entre as inclusões estudadas e as enstatitas cons tituintes dos Therzolitos granulares de kimberlitos.

Outras particularidades das inclusões de enstatita do Brasil estão evidenciadas nos diagramas de variação ternäria en tre os elementos magnēsio, cälcio e ferro II, jlustrados nas F 
$n \cong$ de Inclusões do Brasil

Análises

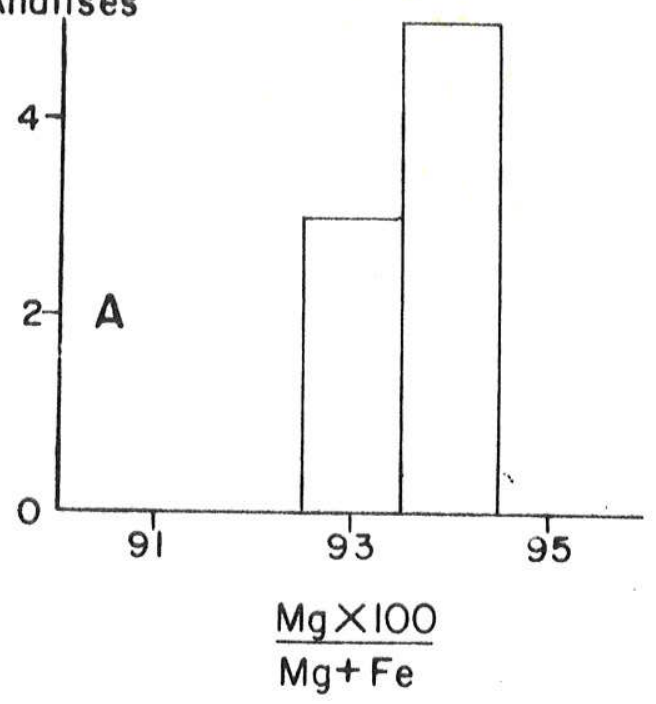

$n \div$ de Análises

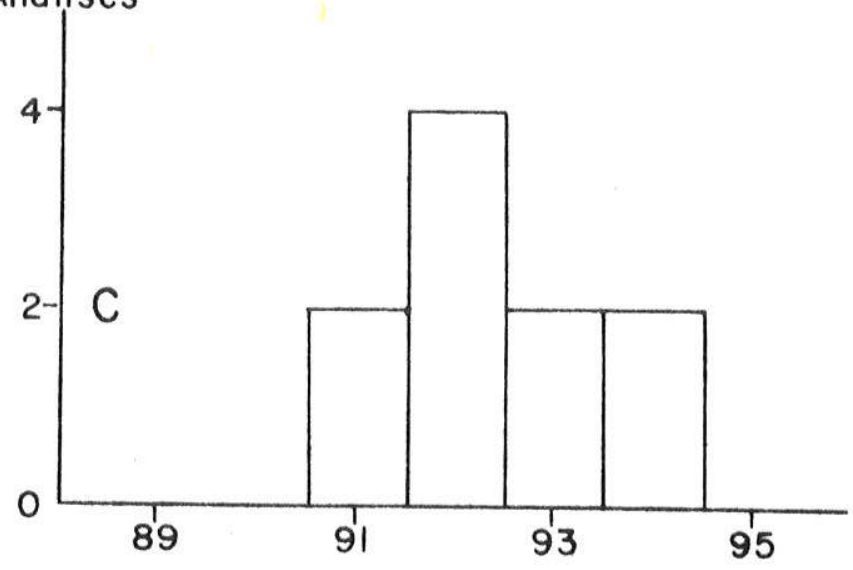

$\mathrm{Mg} \times 100$
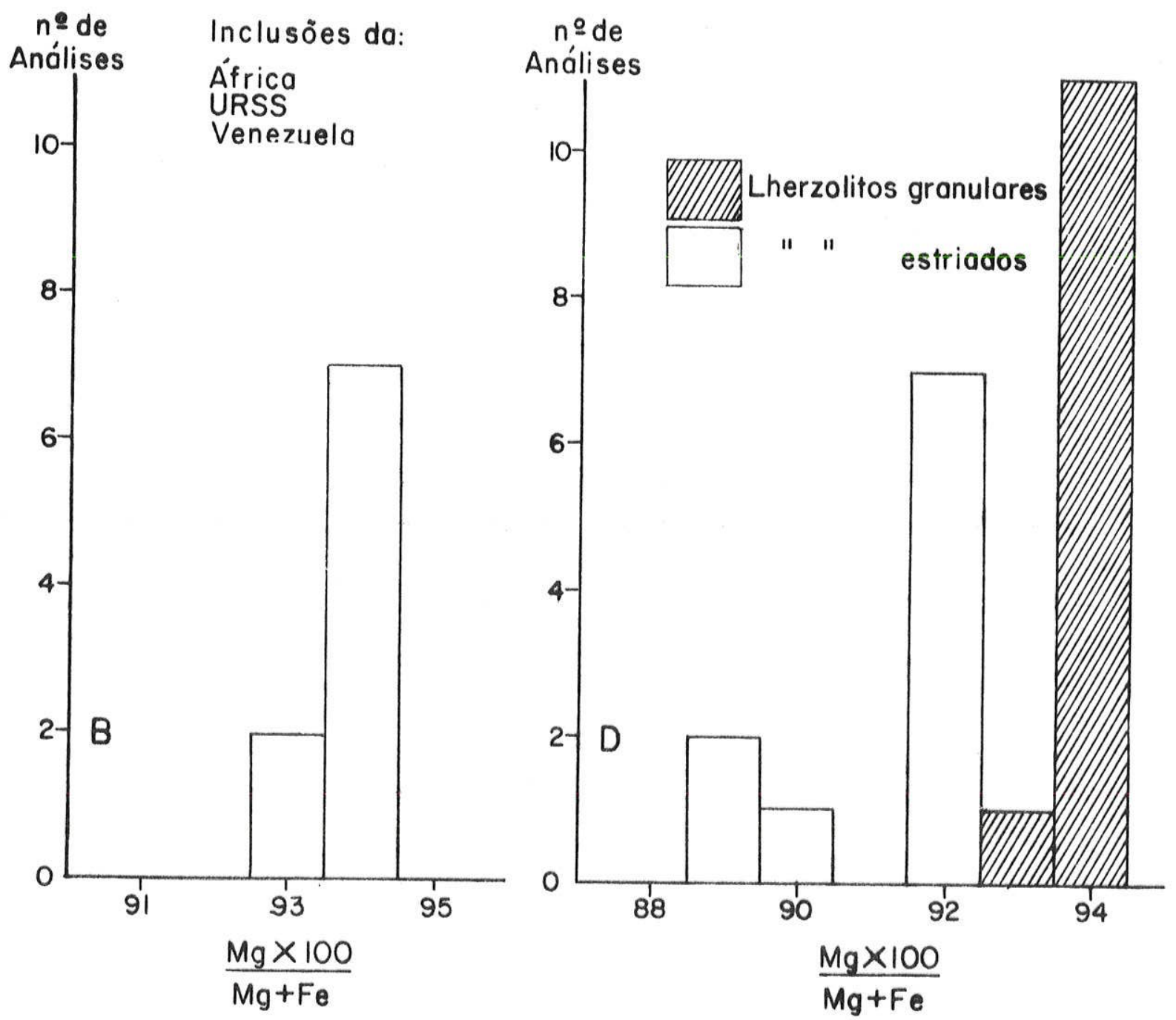

Figura 6 - Comparação das razões Mg $\times 100 / M g+F e$ de enstatitas in clusas em diamantes do Brasil(a). com enstatitas associadas a diamantes de outros paises(b), enstatitas de kimberlitos(c), e enstatitas constituintes de xenólitos de lherzolitos granulares e estriados de kimberlitos (d). Tal como as olivinas, as enstatitas inclusas em diamante (a,b) assemelham-se às enstatitas dos xenólitos granulares $(d)$. Dados comparativos extraidos de MoGETCHIN e SILVER(1970); SOBOLEV et al (1971a); MEYER e BOYD(1972); NIXON E BUYD (1973), ROLFE(1973); BLOOMER E NIXON(1973); BOYD(1974a); SOBOLEV(1974); BOYD \& NIXON(1975); MEYER e TSAI(1976); SVISERO $\mathrm{C}$ GOMES (1977). 


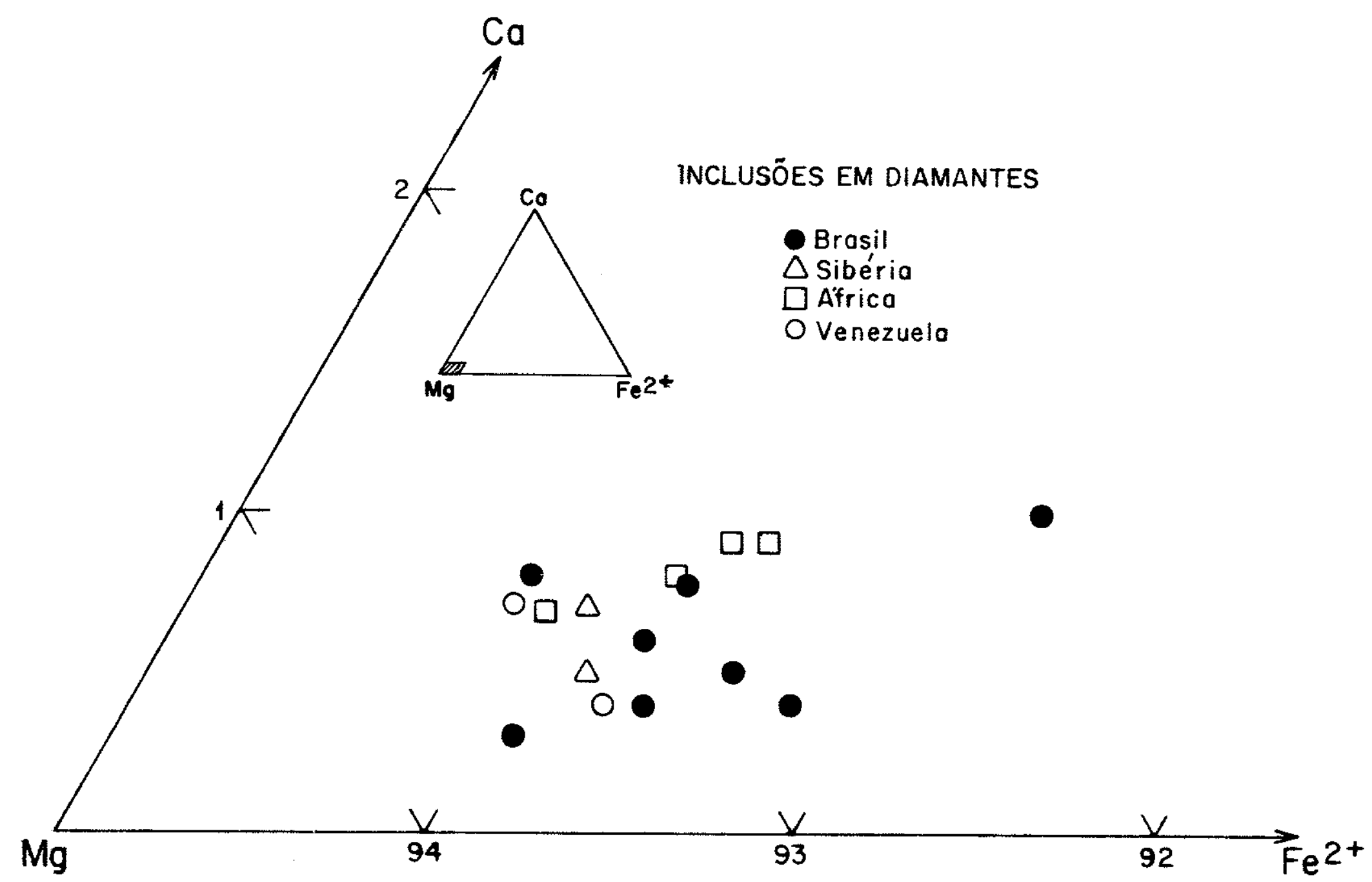

Figura 7 - Diagrama ternário mostrando a variação da composição de enstatitas inclusas em diaman tes do Brasil comparadas com enstatitas equivalentes de diamantes da União Soviéticalsí béria), Africa (Africa do Sul, Gana, Serra Leoa, Tanzânia) e Venezuela. As enstatitas associadas e diamante são acentuadamente megnesianas e quase isentas de cálcio;além dis so, exibem variaçöes limitadas entre os elementos magnésio e ferro. Dados comparativos extraídos de SOBOLEV et al (1971a); MEYER e BOYD (1972); SOBOLEV (1974); MEYER TSAI (1976), SVISERO e GOMES (1977). 


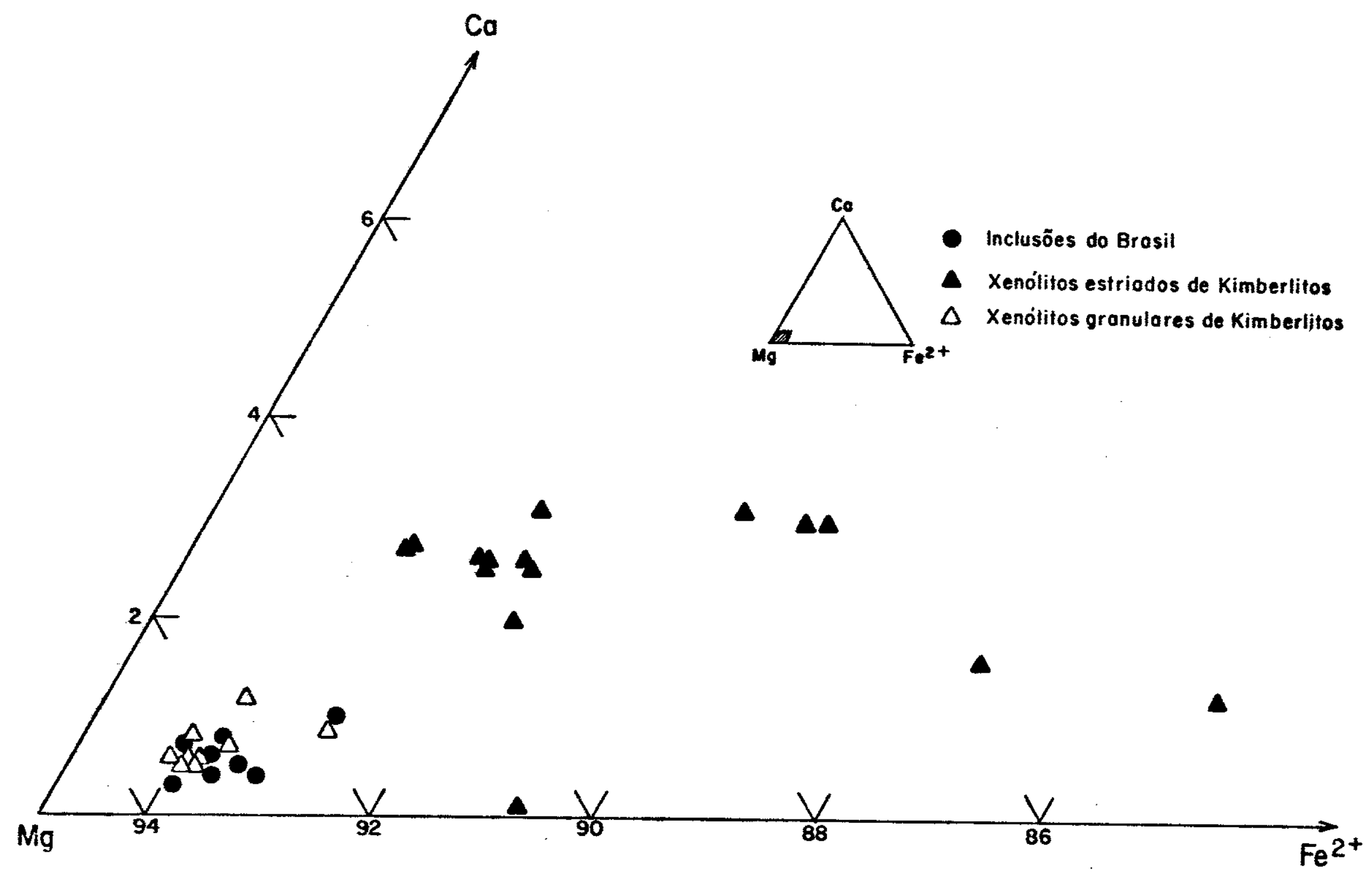

Figura 8 - Diagrama ternário mostrando a variação da composição de enstatitas inclusas em diaman tes do Brasil comparadas com enstatitas constituintes de xenólitos de lherzolitos diaman lares e estriados de kimberiftos. Ol enstatitas presentes nos lherzolitios assemelham-seas GETCHIN e SILVER (1970); NIXONolitos granulares. Dados comparativos extraídos Je Mo(1974a); BOYD E NIXON (1975). 
guras 7 e 8 . 0 diagrama da Figura 7 compara a variação dos refe ridos elementos das enstatitas estudadas, e de inclusões equiva lentes de värios locais do mundo (SOBOLEV et al., 1971a; MEYER e BOYD, 1972; SOBOLEV, 1974; MEYER e TSAI, 1976; SVISERO e GOMES, 1977). Tambēm nesse caso, todas as inclusões exibem proporções uniformes de magnēsio e ferro ao lado de teores reduzidos de cā cio, indicando que a porcentagem de solução sōlida em direção ao diopsīdio ē quase nula. Em diagrama idēntico na Figura 8 , as in clusões estudadas são comparadas com enstatitas de xenōiitos uI tramäficos e concentrados de kimberlitos (MCGETCHIM e SILVER, 1970; NIXON e BOYD, 1973; ROLFE, 1973; BLOOMER E NIXON, 1973; BOYD, 1974b; BOYD e NIXON, 1975). Observa-se que o campo defini do pelo material kimberlitico abriga perfeitamente toda a varia ção exibida pelas inclusões estudadas. Tambēm nesse caso, as enstatitas inclusas nos diamantes estudados apresentam acentuada similaridade com as enstatitas de Therzolitos granulares.

Quanto aos elementos subordinados (Tabela 5 ), todas as inclusöes contēm porcentagens reduzidas de Ti, Al, Cr, Ca. Mn, e $\mathrm{Ni}$. Eram esperados valores baixos de $\mathrm{Al}_{2} \mathrm{O}_{3}$, pois esse elemento é muito sensĩvel ao aumento da pressão (BOYD e ENGLAND, 1964; MacGREGOR, 1974). Dessa forma, os valores por nōs obtidos são perfeitamente compatīveis com as pressões altīssimas envolvidas na formaçäo do diamante na natureza.

CLINOPIROXENIO

Dentro das limitações da amostragem feita verificamos que os clinopiroxēnios constituem uma das inclusões mais raras nos diamantes do Brasil. Esse fato não ē estranho pois värios pesquisadores jā o haviam notado em outros locais do mundo.MEYER e BOYD (1972), por exemplo, examinaram milhares de diamantes de värias jazidas da Äfrica e sō lograram encontrar dois exemplares de diopsídio. 0 mesmo parece ocorrer na União Soviētica onde os 
clinopiroxēnio são tambëm pouco frequentes (SOBOLEV et al., 1975b). Recentemente GURNEY et al. (1977) estudaram cuidadosa mente 232.000 diamantes do kimberlito Finsch, Africa do Sul, en tre os quais não foi observada nenhuma inclusão de clinopiroxê nio.

Contudo, MEYER e TSAI (1976) verificaram, surpreenden temente que nos diamantes do kimberlito Premier, uma das minas clāssicas da Africa do Sul, os clinopiroxēnios são relativamente abundantes. Ainda não hā uma explicação satisfatōria para esse fato. Ao que tudo indica, a frequência dos clinopiroxēnios não parece estar relacionada à idade precambriana do kimberlito (ALSOPP et al., 1977) de vez que diamantes precambrianos de ou tros locais não contēm essa inclusão na frequência observada na Mina Premier.

Os diamantes da região da Serra do Espinhaço, por exem plo, que sabidamente provēm de metassedimentos precambrianos da Formação Sopa-Brumadinho, são pobres em inclusões de clinopiroxẽ nios. Os trēs ūnicos exemplares que localizamos, foram extraỉ dos de diamantes da região oeste de Minas Gerais, cujas fontes, conforme discutiremos em um dos capĩtulos subsequentes, estão re lacionadas ao magmatismo kimberlītico que afetou a região no cre täceo Superior (SVISERO et al., 1978).

As três amostras estudadas exibem cor verde esmeralda intensa e, a julgar pelas descrições da literatura(WILLIANS, 1932; HARRIS, 1968; MEYER e TSAI, 1976), essa parece ser uma das carac terísticas dessas inclusões. A Micrografia eletrōnica 8 mostra uma inclusão de diopsídio com idiomorfismo quáse perfeito. Tra ta-se de um cristal prismātico cujo crescimento se deu de forma tão proporcionada a ponto de ser possivel reconhecer algumas de suas formas cristalogräficas pelo simples exame visual da inclu são. E fācil distinguir o pinacōide da parte superior do cris ta1, que estä circundado por duas faces simētricas em relação ao plano de simetria que contêm os eixos cristalogräficos a e $\underline{c}$. As demais formas não puderam ser reconhecidas, mas levando em con 


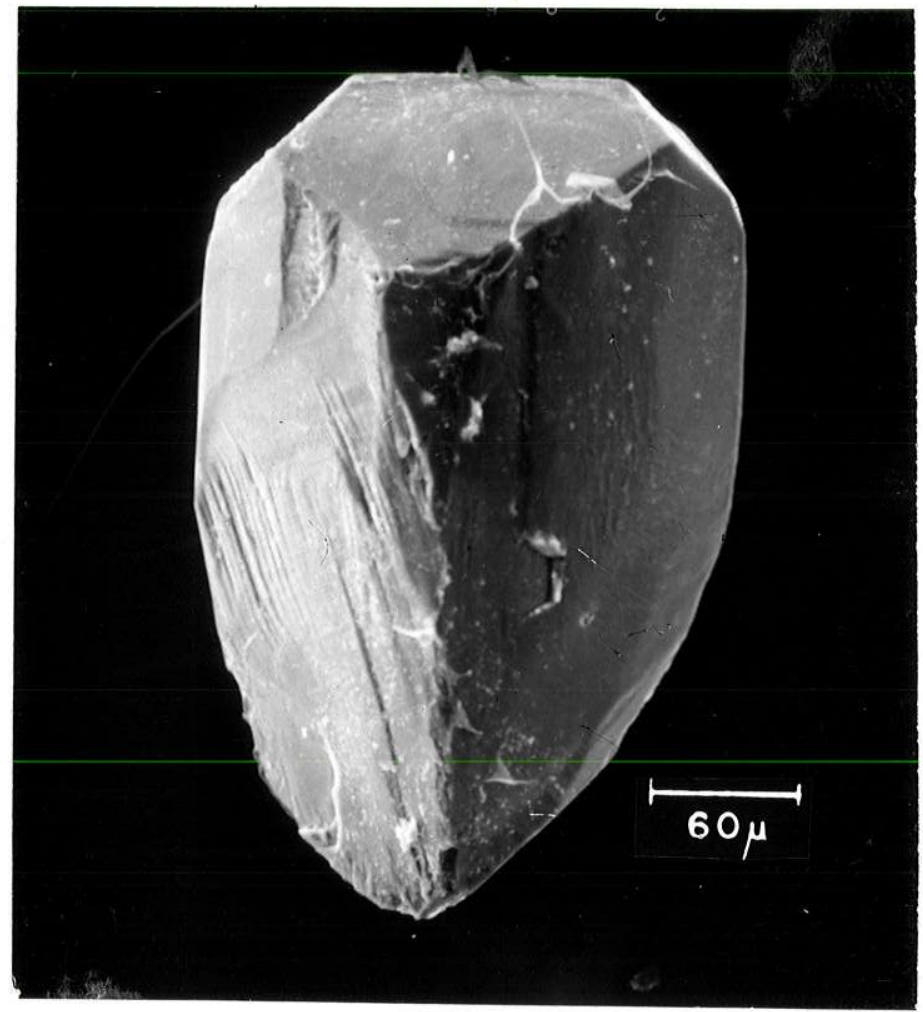

Micrografia eletrônica 8 - Diopsídio com acentuado grau de idiomorfismo. Notar o plano de simetria vertical que divide o cristal em duas partes quase idênticas. Aumento $250 \times$. 
ta o häbito prismätico da inclusão, devem corresponder a outros pinacōides e/ou prismas römbicos. SOBOLEV e BOTKUNOV descreveram alguns exemplos curiosos de diopsídios da sibēria exibindo häbitos octaēdricos. Segundo os referidos autores, tra ta-se de um häbito imposto pelos respectivos diamantes hospede $\underline{i}$ ros.

Onfacita, o outro clinopiroxēnio identificado constị tui intercrescimento cristalino com o diamante, e por motivos ōbvios, não pōde ser fotografado no microscópio eletrōnico de varredura. Ela exibe tambēm cor verde, ligeiramente mais acen tuada do que a do diopsídio e ocorre disseminada em diversos pon tos do hospedeiro incolor.

A Tabela 7 reune anāilises quīmicas dessas duas inclu sões. As diferenças quĩmicas entre ambas são marcantes. 0 diop sĩdio ē mais rico em MgO e CaO do que a onfacita que, por sua vez, ē mais enriquecida em $\mathrm{TiO}_{2}, \mathrm{Al}_{2} \mathrm{O}_{3}, \quad \mathrm{FeO}$ e $\mathrm{Na}_{2} \mathrm{O}$. De um mo do geral, o diopsīdio analisado é semelhante a diopsīdios de xé nölitos ultramäficos de kimberlitos enquanto a onfacita asseme 1ha-se a piroxênios constituintes de xenōlitos de eclogitos de kimberlitos. MEYER e SVISERO (1975) e PRINZ et aZ. (1975) clas sificaram as inclusões desse tipo, que até o momento são os ünicos clinopiroxēnios conhecidos em diamantes, em dois grupos distintos: 1) grupo ultramāfico, reunindo diopsídios comuns e diopsidios cromiferos como aqueles descritos por SOBOLEV et al. (1975b); 2) grupo eclogîtico, formado por onfacitas equivalen tes quimicamente aos piroxēnios dos eclogitos kimberlîticos.

Como reflexo direto dessas diferenças de carater quí mico, esses clinopiroxênios participam de paragēneses totalmen te distintas. Diopsídios com ou sem crômio coexistem em diaman tes com olivina, enstatita e crōmiopiropo, enquanto que a onfacita sō coexiste com piropo-almadina que é equivalente à grana da dos xenōlitos de eclogitos de kimberlitos (SOBOLEV et az., 1970; PRINZ et al., 1975; MEYER e TSAI, 1976). E digno de nota que, uma dessas associações descritas por SOBOLEV et al. (1972a) 
TABELA 7 - COMPOSIÇAOO QUIMICA DE CLINOPIROXENIOS PRESENTES

EM DIAMANTES DO BRASIL

\begin{tabular}{|c|c|c|}
\hline & $M G-52 a$ & $M G-65 a$ \\
\hline $\mathrm{SiO}_{2}$ & 55,20 & 54,30 \\
\hline $\mathrm{TiO}_{2}$ & 0,05 & 0,80 \\
\hline $\mathrm{A}^{\mathrm{A}} 2^{\mathrm{O}} 3$ & 1,22 & 5,86 \\
\hline $\mathrm{Cr}_{2} \mathrm{O}_{3}$ & 1,48 & 0,05 \\
\hline $\mathrm{FeO}$ & 2,53 & 5,65 \\
\hline $\mathrm{MgO}$ & 18,20 & 11,80 \\
\hline $\mathrm{CaO}$ & 19,35 & 16,50 \\
\hline Mno & $<0,01$ & 0,02 \\
\hline $\mathrm{NiO}$ & $<0,01$ & 0,01 \\
\hline $\mathrm{Na}_{2} \mathrm{O}$ & 2,12 & 4,65 \\
\hline $\mathrm{K}_{2} \mathrm{O}$ & 0,05 & 0,12 \\
\hline Total & 100,22 & 99,76 \\
\hline
\end{tabular}

Nümero de cätions $(\times 1000)$ com base em 6 ätomos de oxigênio

$\mathrm{Si}$

Aiv

$A 1^{\vee i}$

$\mathrm{Ti}$

$\mathrm{Cr}$

$\mathrm{Fe}$

$\mathrm{Mg}$

$\mathrm{Ca}$

$\mathrm{Mn}$

$\mathrm{Ni}$

$\mathrm{Na}$

$k$

$\mathrm{FeSiO}_{3}$

$\mathrm{CaSiO}_{3}$

$\mathrm{MgSiO}_{3}$
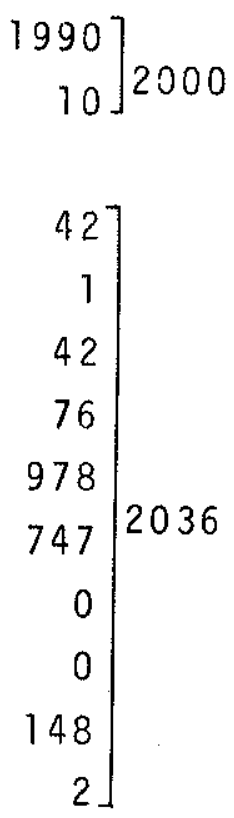

4,19

41,32

54,49
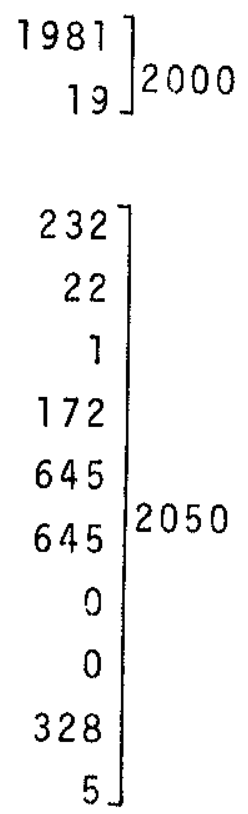

11,68

44,16

44,16 
e que reunia inclusões de onfacita e piropo-almadina, foi extraí da exatamente de diamantes associados a um xenólito de eclogito. SOBOLEV e seus colaboradores observaram que o piroxēnio e a gra nada associados ao diamante eram equivalentes quimicamente aos piroxênios e granadas constituintes do xenōlito de eclogito por tador dos diamantes.

Essas e outras caracteristicas estão ressaltadas nas Figuras 9 e 10 , onde as duas inclusões estudadas estão projeta das no quadrilätero dos piroxēnios. Os referidos gräficos estão acompanhados das temperaturas referentes ao "solvus" - CaMgSi ${ }_{2}{ }_{6}$ a 30 kbars, obtidas experimentalmente por DAVIS e BOYD (1966).

A Figura 9 mostra que os dois clinopiroxēnios identifi cados em diamantes brasileiros, projetam-se dentro do campo de variação definido por inclusões equivalentes associadas a diaman tes da União Soviētica (SOBOLEV et al., 1970, 1971a, 1972a,1975a; SOBOLEV, 1974) e Africa (MEYER e BOYD, 1972; PRINZ et al., 1975; MEYER e TSAI, 1976). O termōmetro geolōgico de DAVIS e BOYD (1966), indica por outro lado que as duas inclusões estudadas se cristalizam a temperaturas relativamente pröximas entre si, res pectivamente a $1050^{\circ}$ e $1150^{\circ} \mathrm{C}$, aproximadamente. Algumas inclú sões subcálcicas cristalizam-se pröximo de $1.400^{\circ} \mathrm{C}$; entretanto,a maior parte dos dados situa-se dentro da fajxa compreendida en tre $950^{\circ}$ e $1150^{\circ} \mathrm{C}$.

No diagrama da Figura 10 , semelhante ao da Figura ante rior, os dois clinopiroxēnios estudados estão reunidos a concen trados de kimberlitos (BOYD, 1969; BOYD E NIXON, 1970; SOBOLEV, 1974; SVISERO et al., 1977), xenōlitos kimberliticos de lherzoli tos granulares e estriados (BOYD e NIXON, 1972; NIXON e BOYD, 1973; BOYD e NIXON, 1975), e a xenólitos de eclogitos de natureza kim berlitica (KUSHIRO e AOKI, 1968; MEYER e BROOKINS, 1971; REID et al., 1976; MEYER, 1977). Como se pode observar pela referida fi gura, os clinopiroxēnios dos therzolitos estriados são subcālcí cos e constituem um campo bem definido caracterizado por tempera 


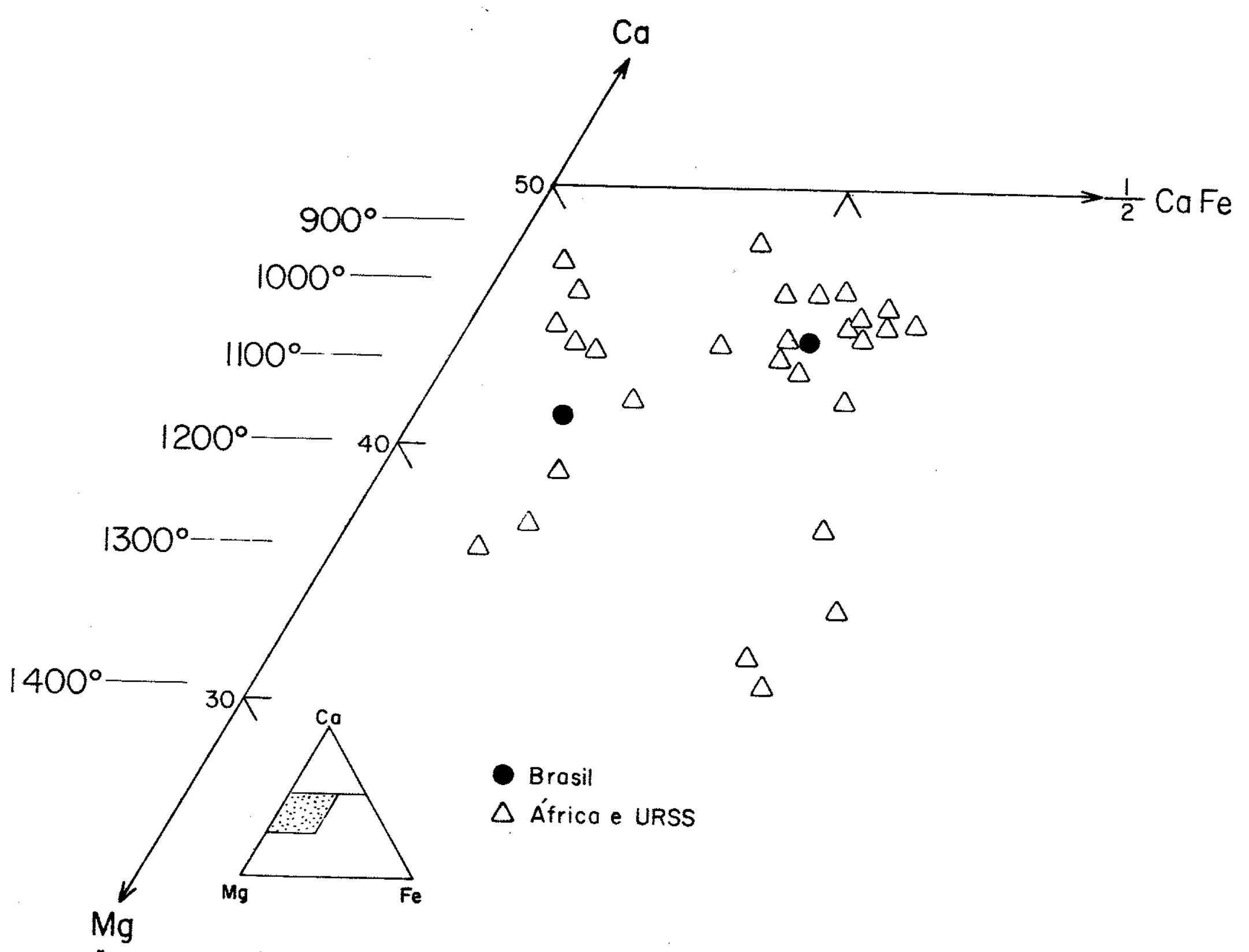

Figura 9-Porção do quadrilátero dos piroxênios mostrando clinopiroxênios inclusos em diamantes do Brasil compara dos com material equivalente da Uniäo Soviética(Sibéria) e Africa do Sul.0bserva-se que as inclusões crís talizam em uma faixa ampla de temperaturas, embora a maior parte dos dados disponiveis concentrem-se no intervalo $1000-1200^{\circ}$ C. As temperaturas referentes ao "solvus" diopsidio-enstatita foram extraídas de DA (1972): SOBOLEV(1974). PRINZ e dados comparativos de SOBOLEV et aZ(1970, 1971a,1972a,1975a);MEYER e BOYD 


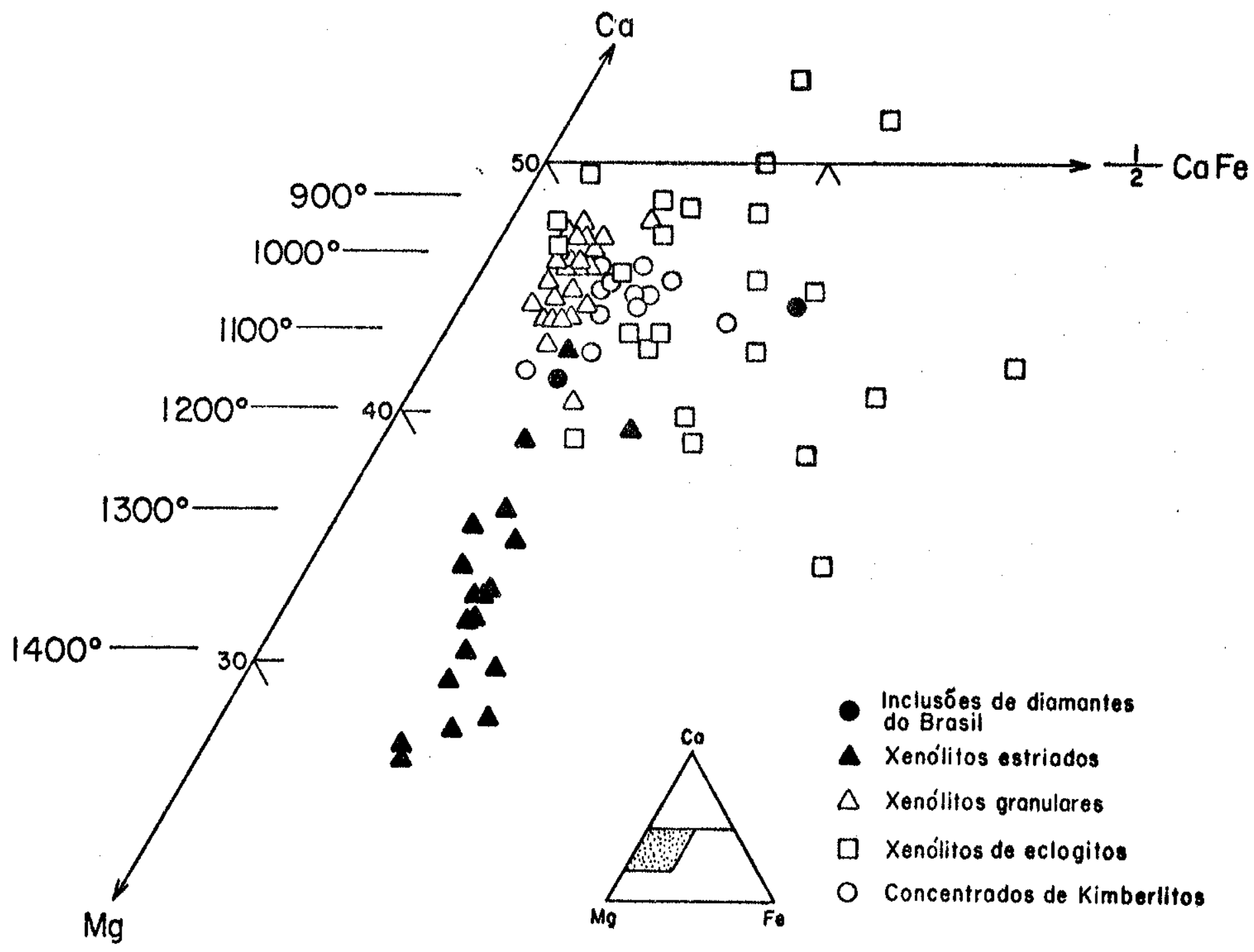

Figura 10 - Varíação da composição de clinopiroxênios de paragêneses diversas projetados em uma poréa do quadrilátero dos piroxénios. Os dols círculos cheios representam as Inclusóes identificadas nos diamantes brasileiros;os de mais pontos referem-se a clinopiroxênios de naturezakim berlítica e incluem xenólitos ultramä́ficos de peridoti= tos e eclogitos, e concentrados de kimberlitos. Embora haja uma cBrta superposição entre os campos correspondentes aos clinopiroxênios de natureza eclogitica com os clinopiroxénios de natureza ultramáfica, incluindo xenó litos de peridotitos e concentrados de kimberlitos, ob= serva-se claramente que uma das inclusões analisada situa-se no campo dos eclogitos; a outra, de natureza ultramäfica, projeta-se no limite dos campos corresponden tes aos Iherzolitos granulares e estriados. As temperaturas referentes ao "solvus" diopsidio-enstatita foram extraidas de DAVIS e BOYD (1966), e os demais dados com parativos de KUSHIRO e AOKI (1968); BOYD (1969);BOYD $\overline{8}$ NIXON (1970); MEYER E BROOKINS (I971); BOYD e NIXON (1972); NIXON \& BOYD (1973); SOBOLEV (1974); BOYD e NIXON (1975); REID et al(1976); MEYER (1977); SVISERO et a. (1977). 
turas de cristalização que podem ultrapassar $1.400^{\circ} \mathrm{C}$. Os clino piroxēnios dos lherzolitos granulares, por sua vez, alëm de mais cālcicos, constituem um campo caracterizado por temperaturas me nores que contēm os concentrados de kimberlitos, e em parte, a 1 guns piroxēnios de eclogitos. Apesar de haver uma pequena super posição entre os clinopiroxēnios de natureza ultramäfica e eclo gïtica, $\bar{e}$ făcil ver que as duas inclusões se projetam em campos distintos. Uma delas projeta-se no campo dos eclogitos; a outra, projeta-se na zona limitrofe dos campos dos Therzolitos granula res e estriados.

Confirma-se dessa forma, a existência de duas sëries de inclusões distintas entre os diamantes brasileiros, a saber: sērie de natureza ultramäfica, e sērie de natureza eclogītica. Tais sēries ou assemblëias de minerais, caracterizadas simulta neamente por MEYER e SVISERO (1975) e PRINZ et az. (1975), não se restringem aos clinopiroxénios; elas englobam outras fases as sociadas ao diamante e voltarão a ser discutidas com pormenores nos capitulos subsequentes.

Quanto aos demais elementos quimicos, deve-se destacar a presença de quantidades razoāveis de crōmio na inclusão do diopsidio (Tabela 5). SOBOLEV et al. (1975a) analisaram diopsi dios de diamantes da Sibēria portadores de atē $12,0 \%$ de $\mathrm{Cr}_{2} \mathrm{O}_{3}$. Segundo eles, a incorporação de crōmio pelo diopsĩdio estä rela cionada às altịssimas pressões envolvidas na cristalização do diamante hospedeiro. Com relação ao $\mathrm{Na}_{2} \mathrm{O}$, os dados referentes às duas anälises indicam proporções pequenas da molēcula jadeĩta no diopsidio e teores relativamente altos na onfacita. No caso da onfacita, o teor de $\mathrm{Na}_{2} \mathrm{O}$ indica que a cristalização desta in clusão, tal como o diopsídio, se operou a pressōes muito altas. Niquel e potässio ocorrem em teores baixos nas duas inclusões. 
GRANADA

Depois das olivinas, as granadas são as inclusões mais comuns em diamantes brasileiros. Em geral elas coexistem com outros minerais, notadamente com a olivina, a enstatita, o cro mioespinēlio e o diopsídio, com os quais constitui associaçóes de dois ou mais componentes (SOBOLEV et al., 1970; PRINZ et al., 1975; MEYER e SVISERO, 1975). A granada é reconhecida de imedia to pelo simples exame microscōpico. Graças às cores constantes e caracteristicas, as inclusões maiores podem ser reconhecidas, às vezes, atē à vista desarmada. Nesse caso, assemelham-se a pequenos pontos avermelhados circundados por uma faixa escura de corrente da diferença de relevo entre a granada e o diamante ho pedeiro.

No decorrer dessa investigação, caracterizamos dois grupos de inclusões de granadas. Um deles, o mais frequente, $\bar{e}$ constituido de granadas piropo ricas em crōmio, cujos cristais exibem cores variāveis entre vermelha escura, vinho, violeta e verde escura. 0 segundo grupo, bem menos frequente, desenvolve cristajs de coloração variävel entre a da laranja e a do mel, sen do constituidos essencialmente pelos termos piropo e almandina. Esses dois grupos de granadas possuem composição química bem de finida como.teremos oportunidade de discutir neste capitulo, é serão referidos doravante apenas pelas denominações crómiopiro po e piropo-almandina.

Do ponto de vista morfológico, as inclusões de granada apresentam-se sob a forma de cristais complexos, desproporciona dos, em geral constituidos por um grande nümero de faces. 0 hä bito nem sempre pode ser caracterizado em virtude do acentuado abaulamento das faces, o que dificulta o reconhecimento das for mas simples presentes. A Micrografia eletrónica 9 ilustra uma inclusão de crômiopiropo, cujo cristal è equidimensional e de hä bito globular, aproximadamente tabular. Nesse caso ë possível re 


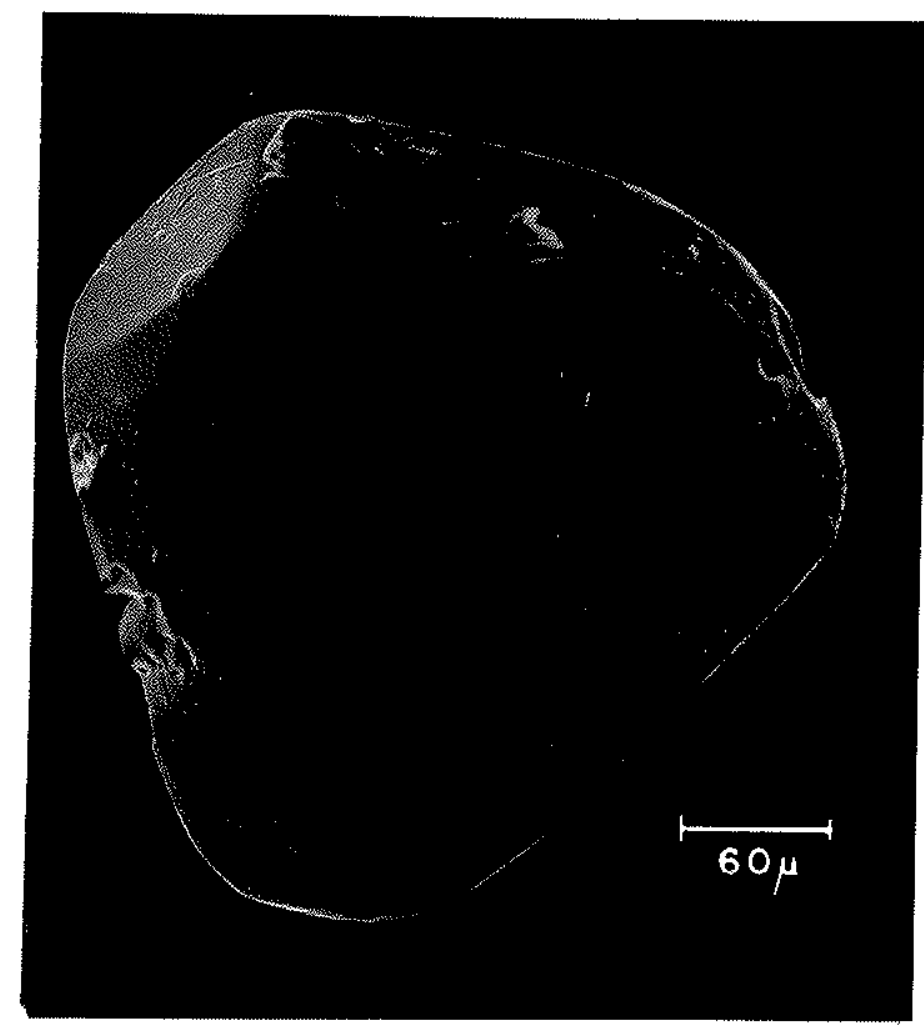

$-57-$

Micrografla eletrónica 9 - Granada piropo de hábito globular.Aumento $250 \mathrm{x}$.

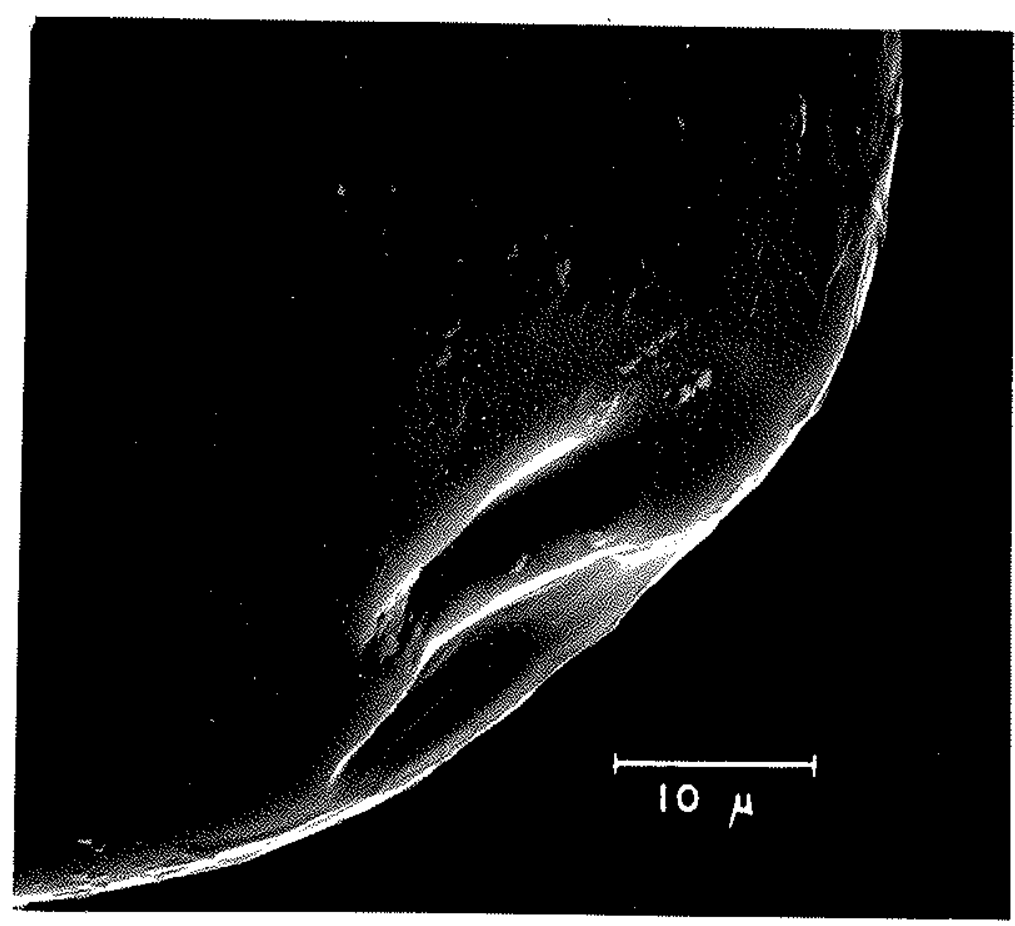

Micrografla eletrónica 10 - Pormenor do cristal anterior mostran do cavidades elípticas e paralezas na superficie.Au" mento $2.000 x$. 
conhecer que se trata de uma combinação entre octaedro e rombodo decaedro, onde o desenvolvimento mais acentuado de duas faces octaédricas paralelas torna o cristal ligeiramente achatado.

Um exemplo excelente de desproporcionamento cristali no estā ilustrado na Micrografia eletrōnica 11. Trata-se de uma inclusão de piropo-almandina excessivamente alongada segundo um dos eixos de simetria binäria do cristal. Embora o espécime te nha se fraturado durante sua retirada do interior do hospedeiro, $\bar{e}$ possivel ver que o häbito è aproximadamente fusiforme. Häbitos semelhantes aos aqui descritos, não são estranhos em diamantes. LEITE (1969) e SVISERO (1971) descreveram diamantes tabulares e fusiformes em proporções semelhantes nos garimpos de Minas Gerais, Mato Grosso e Goiäs respectivamente. SOBOLEV e BOTKUNOV (1972) mencionaram um caso interessante em que inclusões de natureza totalmente diferente, apresentavam häbitos octaēdricos, nitidamen te influenciados pelo hospedeiro. Levando em conta a sugestãode SOBOLEV, ē provāvel que os häbitos das inclusões referidas nas Micrografias 9 e 11 tenham sido condicionados pelos respectivos diamantes hospedeiros.

Embora as duas granadas descritas sejam distintas no que diz respeito à cor, morfologia e composição quimica, ambas apresentam cavidades elipticas regulares em suas superfícies. As Micrografias eletrōnicas 10 e 12 ilustram essas microestruturas que como se recorda, jä foram mencionadas no capitulo referente às olivinas. Na ocasião, aventamos a possibilidade delas se for marem durante o despreendimento de substäncias volāteis do inte rior das inclusões em uma fase primordial ígnea. Infelizmente, as informações disponiveis sobre a morfologia das inciusões cris talinas e a existēncia ou não de substäncias fluidas no diamante são tão escassas que e quase impossĩvel qualquer discussão defi nitiva sobre a origem dessas microestruturas. Afora as descri ções de SOBOLEV e BOTKUNOV (1972) sobre häbitos de inclusões da Sibēria, e de algumas inferēncias esparsas e inconclusivas sobre possiveis compostos gasosos em diamantes (BREWSTER, 1853; 


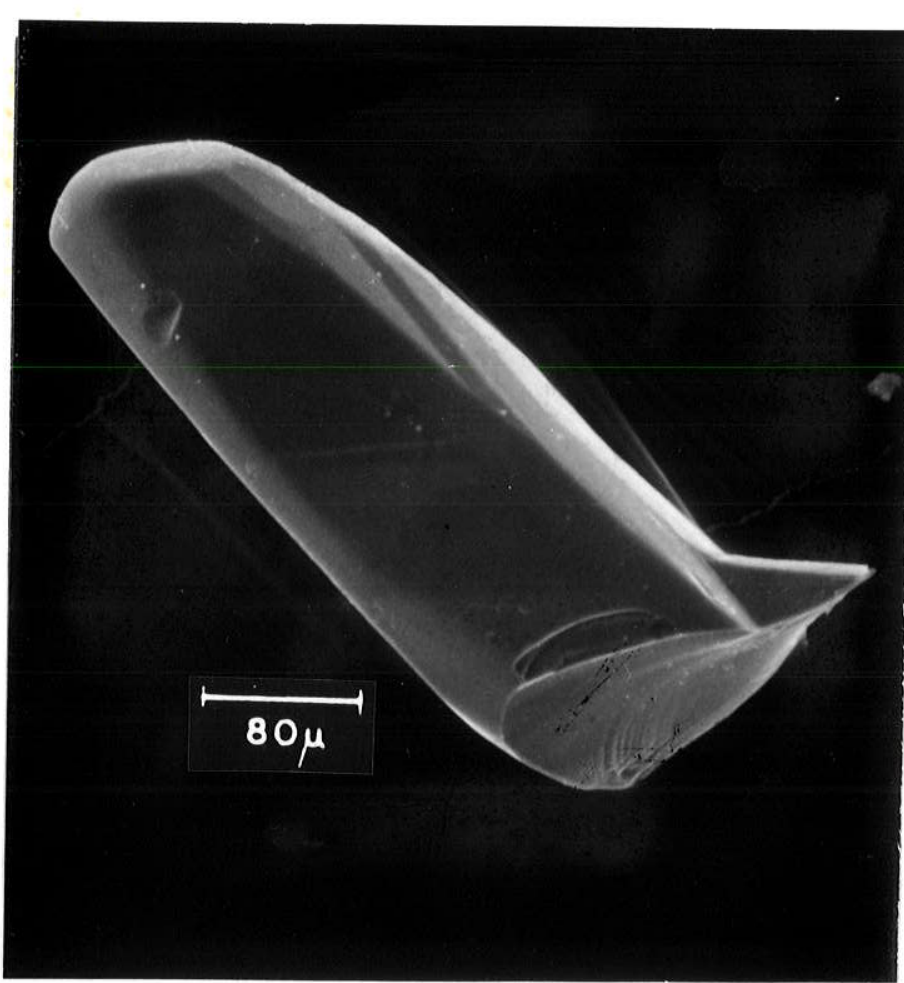

Micrografia eletrônica 11 - Granada piropo-almandina com acentuado desproporcionamento segundo um dos eixos de simetria binária. Aumento $200 \times$.

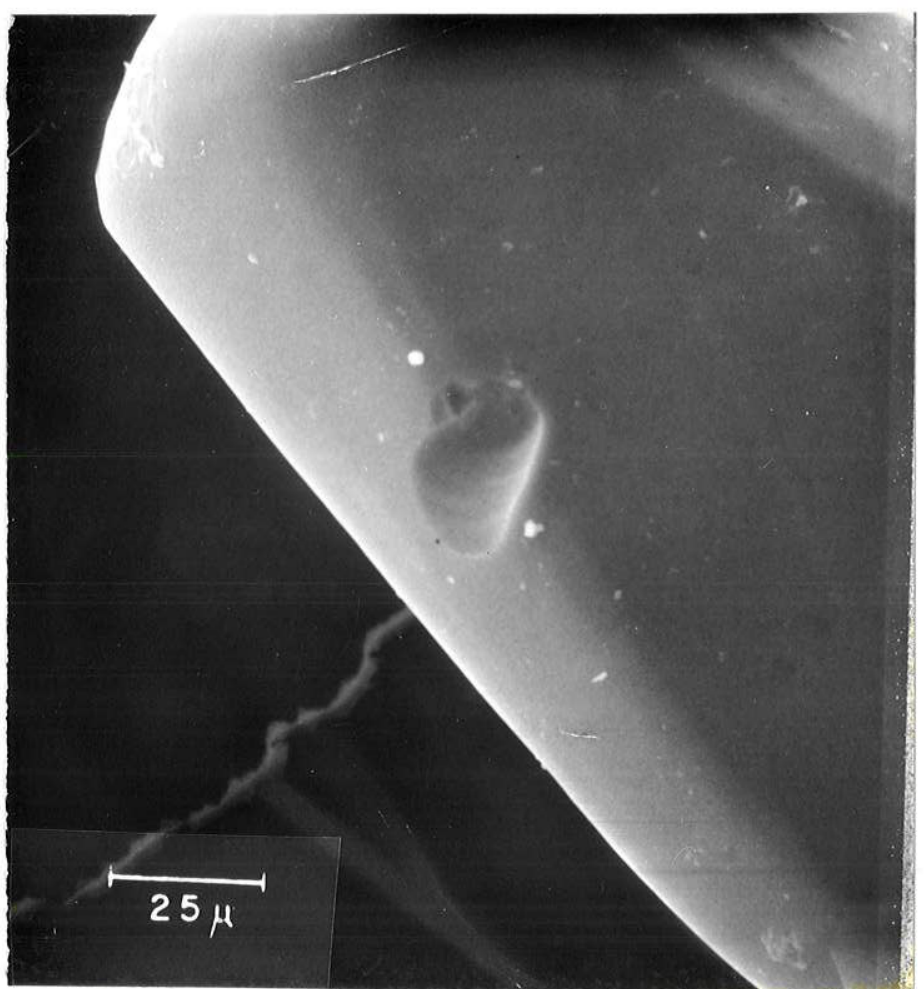

Micrografia eletrônica 12 - Pormenor do cristal anterior mostran do cavidades na superfície. Aumento $600 x$. 
JANNETTAZ, 1879; GÜBELIN, 1952; MELTON e GIARDINI, 1974) nada mais se conhece sobre esses temas. A nosso ver, trata-se de as pectos importantissimos que poderiam ser extremamente ūteis na compreensão dos episōdios relacionados à cristalização das inclu sões.

A composição quĩmica de onze granadas extraĩdas de dia mantes brasileiros estäo apresentadas na Tabela 8 . Elas abran gem amostras provenientes de garimpos diversos (Tabela 1) e in cluem sete cromiopiropos e quatro piropo-almandinas. Em todas as anālises, os teores de $\mathrm{FeO}_{\text {e }} \mathrm{Fe}_{2} \mathrm{O}_{3}$ foram calculados a partir do valor total de ferro fornecido pela microssonda eletrónica, de modo a satisfazer a förmula geral das granadas $x_{3}{ }^{2+} y_{2}^{3+}\left(\mathrm{SiO}_{4}\right)_{3}$. A letra $X$ representa as posições de equilíbrio dos cátions de coordenação cūbica (nümero de coordenação 8) que podem ser ocu padas pelo magnēsio, cälcio, ferro Il e manganēs. As posições $Y$, por sua vez, são ocupadas pelos cātions de coordenação octaédri ca (nümero de coordenação 6) representados pelo aluminio, ferro III, crōmio e titānio. Embora a maior parte do aluminio apresen te nümero de coordenação seis, alguns ätomos desse elemento par ticipam de coordenações tetraēdricas e nesse caso substituem āto mos de silicio na rede cristalina.

A variação dos elementos principais estā representada em dois tipos de diagramas de variação ternäria: um relativo aos elementos quỉmicos alumínio, crōmio e ferro III (número de coor denação 6), e outro para os elementos magnēsio, cālcio e ferro II (nūmero de coordenação 8). Inicialmente, construímos dois dia gramas contendo dados somente de inclusões de diversas procedén cias geogräficas (Figuras 11 e 12). Neles, as onze amostras es tudadas estão comparadas com granadas de diamantes da União So viētica (SOBOLEV et al.,1969, 1970, 1971, 1971a, 1972a; SOBOLEV, 1974), värios paĩses da Africa (MEYER e BOYD, 1972; PRINZ et aZ., MEYER e TSAI, 1976) e Venezuela (SVISERO e GOMES, 1977).

0 exame conjunto dos referidos gräficos comprova, niti damente, a existência dos dois grupos de granadas que jä vinham 
TABELA 8- COMPOSIÇAO QUTMICA DE INCLUSOES DE GRANADA PRESENTES EM DIAMANTES DO BRASIL

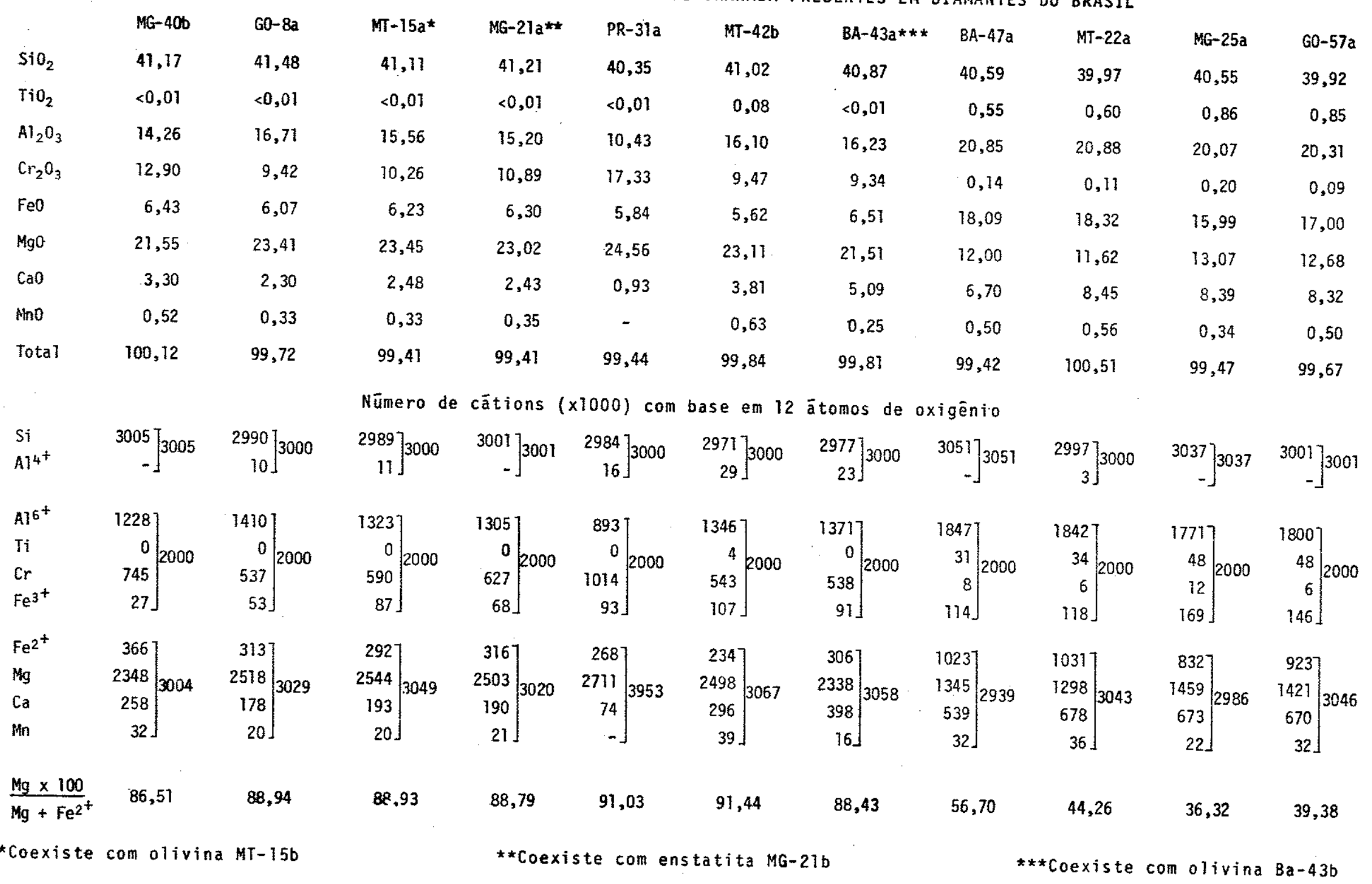


TABELA 9 - PORCENTAGENS DAS MOLECULAS CONSTITUINTES DAS GRANADAS INCLUSAS EM DIAMANTES BRASILEIROS

\begin{tabular}{|c|c|c|c|c|c|c|c|}
\hline & $\begin{array}{l}\mathrm{Mn}_{3} \mathrm{Al}_{2}\left(\mathrm{SiO}_{4}\right)_{3} \\
\text { Espessartita }\end{array}$ & $\begin{array}{c}\mathrm{Ca}_{3} \mathrm{Fe}_{2}\left(\mathrm{SiO}_{4}\right)_{3} \\
\text { Andradita }\end{array}$ & $\begin{array}{l}\mathrm{Mg}_{3} \mathrm{Cr}_{2}\left(\mathrm{SiO}_{4}\right)_{3} \\
\text { Knorringuita }\end{array}$ & $\begin{array}{c}\mathrm{Mg}_{3} \mathrm{Al}_{2}\left(\mathrm{SiO}_{4}\right)_{3} \\
\text { Piropo }\end{array}$ & $\begin{array}{c}\mathrm{Fe}_{3} \mathrm{Al}_{2}\left(\mathrm{SiO}_{4}\right)_{3} \\
\text { Almandina }\end{array}$ & $\begin{array}{c}\mathrm{Ca}_{3} \mathrm{Al}_{2}\left(\mathrm{SiO}_{4}\right)_{3} \\
\text { Grossuläria }\end{array}$ & Total \\
\hline$M G-40 b$ & 1,0 & 1,3 & 37,2 & 40,8 & 12,1 & 7,6 & 100,0 \\
\hline $\mathrm{GO}-8 \mathrm{a}$ & 0,6 & 2,6 & 26,9 & 57,2 & 10,4 & 3,0 & 100,7 \\
\hline MT-15a & 0,6 & 4,0 & 29,0 & $5.5,5$ & 9,5 & 2,0 & 100,5 \\
\hline MG-21a & 0,7 & 3,5 & 31,0 & 52,1 & 10,5 & 2,2 & 100,0 \\
\hline PR-31a & - & - & 50,8 & 37,4 & 8,9 & 2,5 & 99,6 \\
\hline MT-42b & 1,0 & 5,0 & 27,0 & 56,5 & 7,5 & 3,5 & 100,5 \\
\hline$B A-43 a$ & 0,4 & 4,0 & 26,9 & 51,5 & 10,0 & 7,5 & 100,3 \\
\hline BA-47a & 1,0 & 8,4 & 0,4 & 43,5 & 33,4 & 12,8 & 99,5 \\
\hline MT-22a & 1,0 & 8,5 & 0,4 & 42,5 & 34,5 & 13,5 & 100,4 \\
\hline$M G-25 a$ & 0,6 & 12,4 & 0,4 & 47,5 & 27,3 & 12,4 & 100,6 \\
\hline G0-57a & 1,0 & 12,0 & 0,0 & 47,0 & 30,4 & 10,4 & 100,8 \\
\hline
\end{tabular}




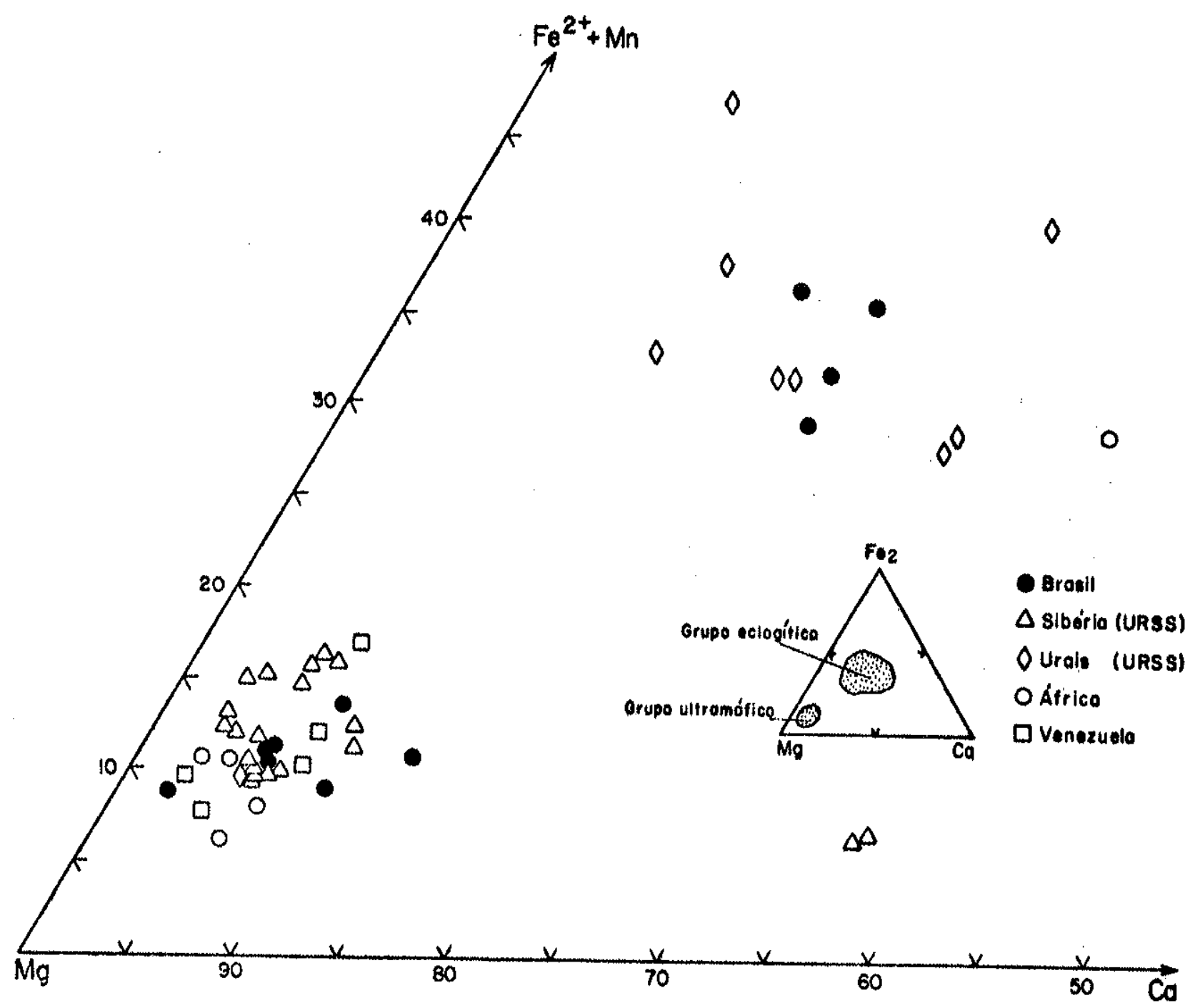

Figura 11 - Dlagrama ternário mostrando a variação da composição de granadas inclusas em diamentes do Brastl, comparadas com material equivalente da União Soviética (Sibéria Urais), Africa do Sul, Gana, Serra Leoa e Venazuela.ob serva-se a existência de dols campos distintos: um de natureza peridotitica reunindo granadas magnesianas po bres de cálcio, e outro menos numeroso constitufdo por granadas de natureza eclogitica com proporçóes equivalentes dós três elementos principais. Dados comparativos extrafdos de SOBOLEV et al (1969, 1970, 1971,1971a, 1972a), MEYER a BOYD (1972); SOBOLEV (1974); PRINZ et al (1975), MEYER a TSAI (1976), SVISERO e GOMES(1977). 


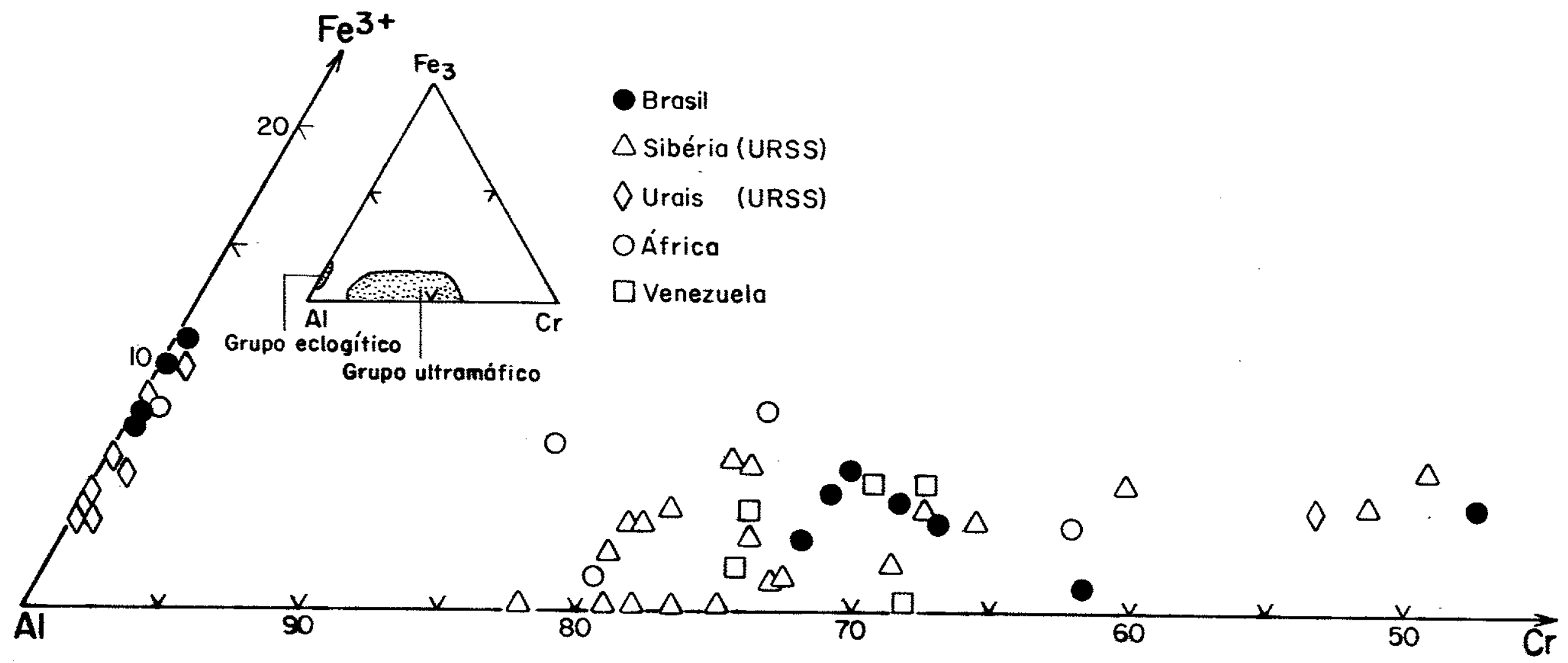

Figura 12 - Diagrama ternário mostrando a varieção da composição de granadas inclusas emi diamantes do Brasil, compradas com material equivalente da Uniäo Soviética(Sibéria e Urais), Africa do Sul, jana, Serre Leoa e Venezuela. As granadas inclusas em diamantes säo gene ralizadamente pobres em ferro III, as de natureza peridotítica contém teores variáveis de crómio; as de natureza eclogítica, por sua vez, caracterizam-se pela ausência de crô mio em sua composiçäo. Dados comparctivos extraídos de SOBOLEV et al (1969, 1970, 1971 , 1971a, 1972a); MEYER e BOYD (1972); SOBOLEV (1974), PRINZ et al (1975); MEYER e TSAI (1976); SVISERO \& GOMES (1977) 
sendo mencionados desde o inicio deste capitulo. o grupo mais abundante, o das crómiopiropos, ē constituído por granadas alta mente magnesianas, com proporções baixas de cälcio e ferro II (Figura 11). Pobres em ferro III, apresentam variações acentua das no que diz respeito aos seus teores de crōmio e aluminio (Fi gura 12). O segundo grupo, o das piropo-almandinas, reune grana das com teores equivalentes de magnēsio, cälcio e ferro II (Figu ra 11). Em adição,elas são extremamente ricas em alumínio, po bres de ferro II e quase isentas de crōmia (Figura 12).

Embora as Figuras 11 e 12 reunam granadas de fontes afastadas entre si, värios milhares de $\mathrm{km}$, não hä entre elas dis crepāncias quỉmicas merecedoras de destaque. 0 alto teor em crō mio de uma das inclusões brasileiras, a PR- 3la cujo teor de $\mathrm{Cr}_{2} \mathrm{O}_{3} \overline{\mathrm{e}} \mathrm{da}$ ordem $17,33 \%$ (Tabela 7), pode ser explicado como uma simples questão de amostragem. E provävel que ä medida que o nümero de anälises aumentar outras inclusões semelhantes venham a ser encontradas.

Nos diagramas 13 e 14 as inclusões estudadas são compa radas com granadas de xenōlitos ultramäficos diversos de kimber 1itos (SOBOLEV et al., 1969a; MaCGREGOR e CARTER, 1970; BOYD e NIXON, 1972; COX et al., 1973; BLOOMER e NIXON, 1973; NIXON e BOYD, 1973; BOYD, 1974a; SOBOLEV, 1974), concentrados de kimber 1itos (NIXON, 1973; SOBOLEV et az., 1973; SWITZER, 1975; SVISERO et al., 1977), e xenóllitos de eclogitos de kimberlitos (KUSHIRO e AOKI, 1968; MEYER e BROOKINS, 1971; REID et al., 1976). A anä 1 ise conjunta desses gräficos ressalta as caracteristicas para genëticas distintas dos dois grupos de granadas. As inclusões de piropo-almandinas são equivalentes às granadas constituintes dos xenölitos eclogiticos de kimberlitos. Quanto às crómiopiro pos, embora essas inclusões se situem dentro do campo definido pe las granadas constituintes dos xenölitos ultramäficos e dos con centrados de kimberlito, elas possuem certas caracteristicas prō prias que as distinguem das demais granadas de natureza kimber 1itica. Alëm de conterem teores altos de magnësio, as crômiopi 


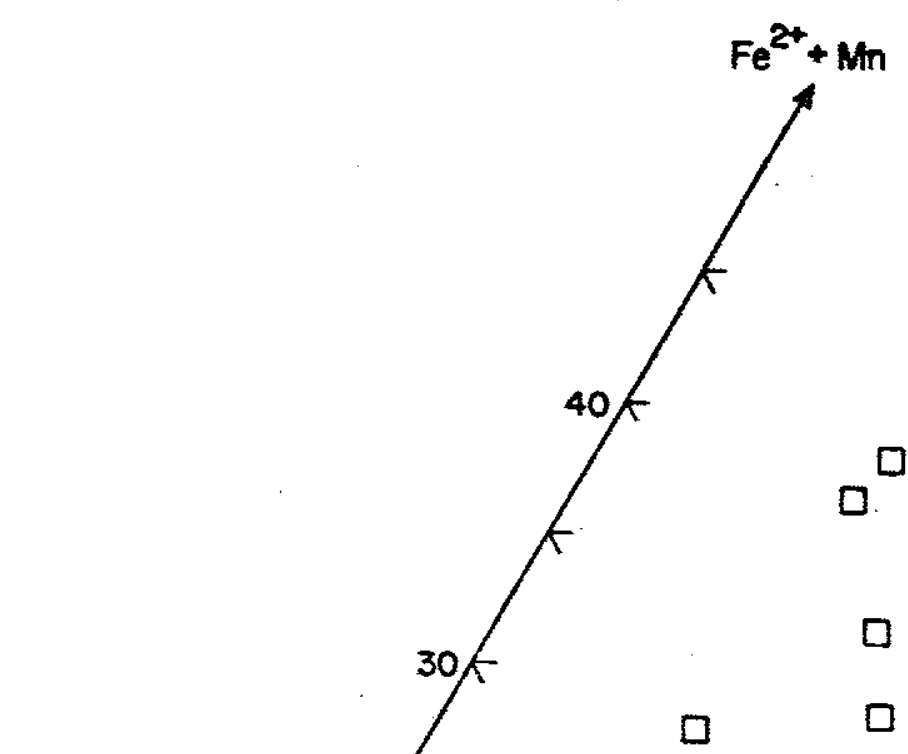

$\Delta \Delta$$$
\Delta
$$

ㅁ 8

$\square$<smiles>[Li][Mg]</smiles>
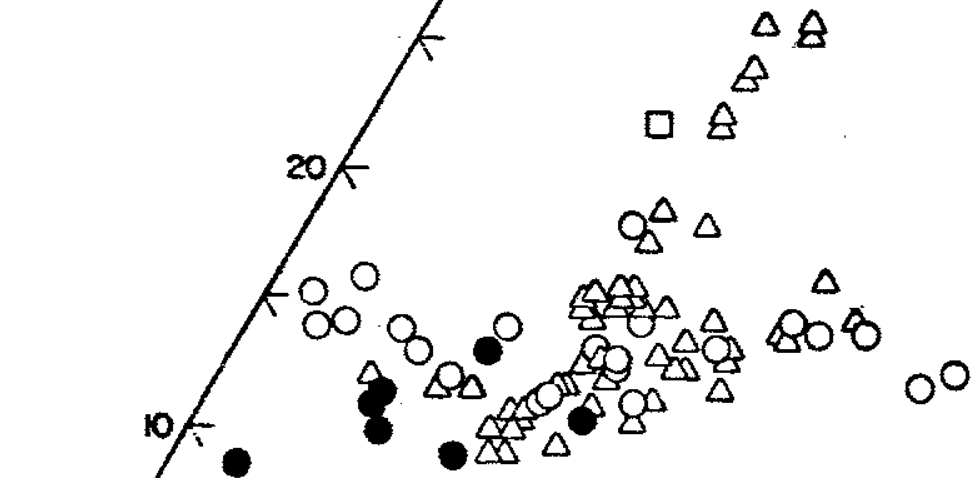

$\square^{\square}$<smiles>[13CH3]</smiles>

$\square$<smiles>[125IH]</smiles>

$\square$

$\square$

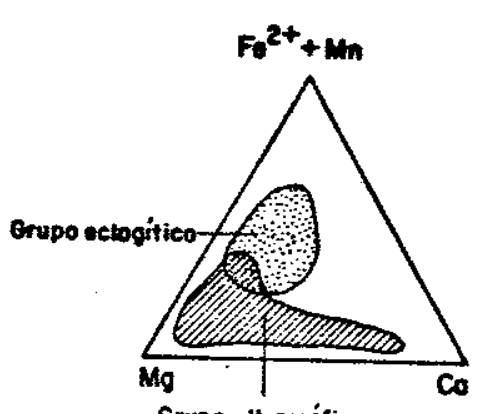

Grupo ulitromófico

Inctusbes em diamantes do Brosil

O Concentrados de kimbertitos

$\triangle$ Xenolitos de peridotitos em kimberlitos

$\checkmark$ Xenólitos de eclogitos em kimberlitos

0

$\circ$

$0^{\circ} \infty_{0}^{\circ}$
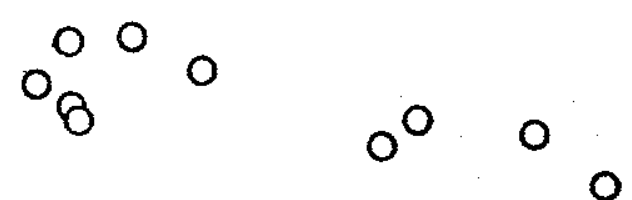

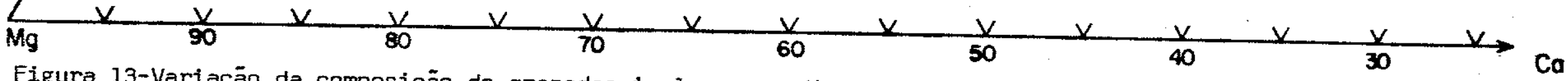

Figura 13-Variaçāo da composição de granadas inclusas em diamantes do Brasil comparadas com granadas tes de xenólitos de peridotitos e eclogitos de natureza kimberlítica, e concentrados de kimberlitos. As granadas de natureza ultramäfica ou peridotítica apresentam variaçäo ampla no que diz respeito as ele eclogítica a variaçäo é menosiaçäo restrita em relação ao ferro II.Com relação as granadas de naturezá as inclusōes estudadas a ma elementos magnésio e ferro II.Entre dotite campo correspondente as granadas de natureza no contram-se (1970); MEYER e BROOKINS(1971) extraidos de KUSHIRD e AOKI(1968); SOBOLEV et al (I969a);MacGREGOR e CARTER (1973); NIXON(1973); SOBOLFV et al (1973), RO et al (1977). 


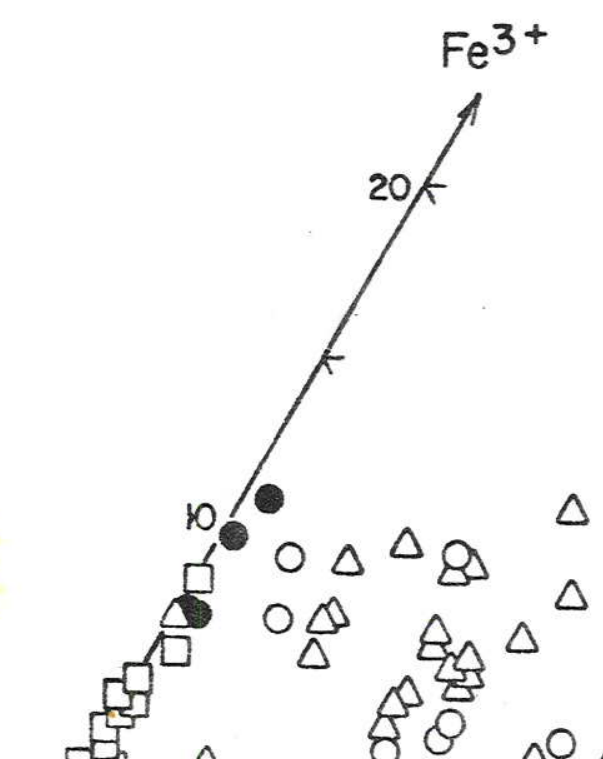

$\triangle$

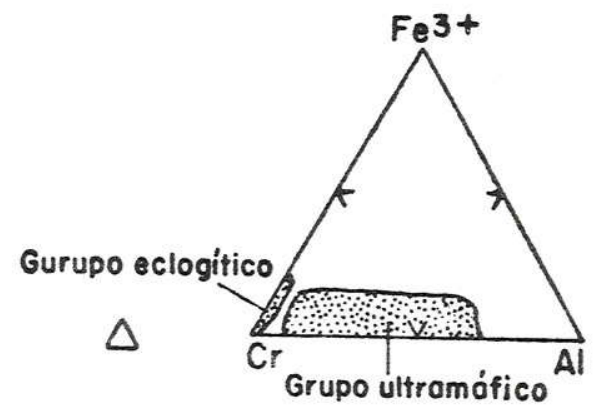

Inclusöes em diamantes do Brosil

O Concentrados de kimberlitos

$\triangle$ Xenólitos de peridotitos em kimberlitos

$\square$ Xenólitos de eclogitos em kimberliłos

O

$0 \quad 0$

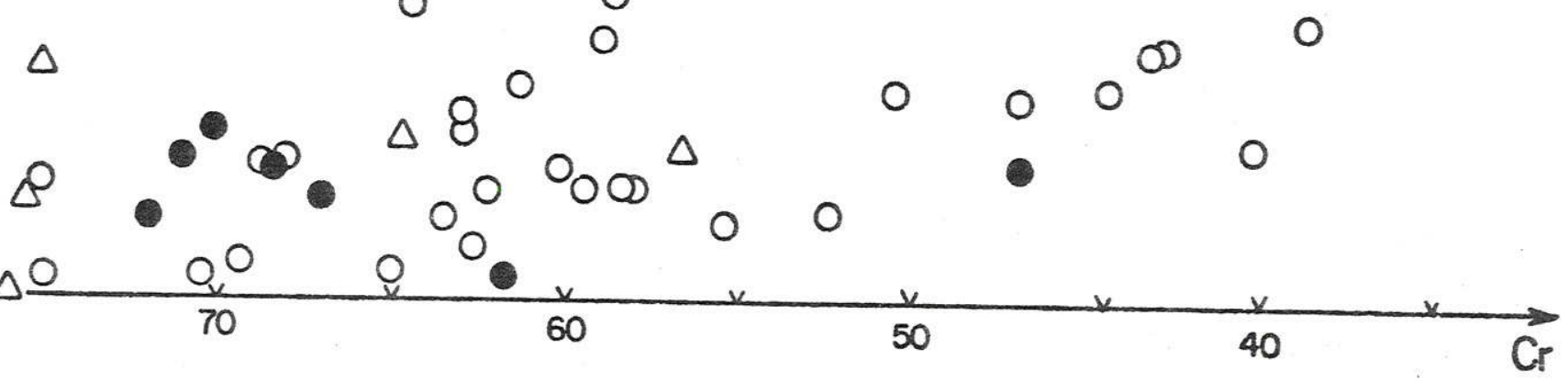

Figura 14 - Variação da composição de granadas inclusas em diamantes do Brasil comparadas com granadas constituintes de xenólitos de peridotitos e eclogitos de natureza kimberlí tica, e concentrados de kimberlitos. As granadas de natureza ultramáfica ou peridotítica apresentam variação ampla no que diz respeito aos elementos alumínio e crómio, e dessa forma, diferenciam-se facilmente das granadas de natureza eclogitica, que além de não possuirem crômio, variam muito pouco em relação aos elementos alumí nio e ferro III. Dados comparativos extraidos de KUSHIRO e AOKI (1968); SOBOLEV et al (1969a); MaCGREGOR \& CARTER (1970); MEYER \& BROOKINS (1971); BOYD e NIXON(1972); COX et al (1973); BLOOMER E NIXON (1973); NIXON e BOYD (1973); NIXON (1973); SOBOLEV et al (1973); SOBOLEV (1974); BOYD (1974a); SWITZER (1975); REID et al (1976); 
ropos são pobres de cāicio e excepcionalmente ricas em crômio (Tabela 8).

Todas as relações discutidas nos diagramas de varia ção ternäria estão sintetizadas no diagrama da Figura 15 que ex plora as variações das razões $\mathrm{Cr}_{2} \mathrm{O}_{3} / \mathrm{Cr}_{2} \mathrm{O}_{3}+\mathrm{Al}_{2} \mathrm{O}_{3}$ e $\mathrm{MgO} / \mathrm{MgO}+\mathrm{FeO}$. Nesse gräfico, as inclusões de granadas identificadas nos dia mantes brasileiros são comparadas com granadas constituintes de xenölitos ultramäficos de kimberlitos (CARSWELL e DAWSON, 1970; NIXON E BOYD, 1973; BLOOMER E NIXON, 1973; SOBOLEV, 1974; BOYD e NIXON, 1975; HEARN E BOYD, 1975), concentrados de kimberlitos (NIXON E HORNUNG, 1968; SOBOLEV et al., 1973; GURNEY e SWITZER, 1973; MEYER, 1975; SWITZER, 1975; SVISERO et al., 1977) e xenō 1itos de eclogitos (SOBOLEV e KUZNETSOVA, 1966; MEYER e BROOKINS, 1971; REID et al., 1976). Confirma-se a divisão das inclusões em dois grupos distintos com base em suas relações paragenēti cas, e as demais características quỉmicas jā ressaltadas, ou se jam: acentuado enriquecimento em magnësio e crōmio por parte das crōmiopiropos em detrimento das piropo-almandinas. No to cante à associação mineralōgica ultramäfica hā que destacarmais uma vez o relacionamento estreito entre as inclusões e as grana das dos xenōlitos ultramäficos, fato que jā havia sido destaca do nas olivinas, enstatitas e diopsidios.

Diversas particularidades fazem das granadas crōmiop $\underline{i}$ ropo um grupo de inclusões totalmente à parte, e portanto, mere cedor de algumas considerações adicionais. Talvez a caracterís tica mais notāvel dessas granadas seja seus teores de crômio cuja variação cobre todo intervalo entre 0 a $18,0 \%$ de $\mathrm{Cr}_{2} \mathrm{O}_{3}$ (HORNUNG e NIXON, 1973; ROST et al., 1975). As crōmiopiropos são de ocorrēncia restrita na natureza. Alëm de inclusões em diamantes, elas aparecem esparsamente em xenōlitos ultramäficos de kimberlitos e em concentrados de kimberlitos (REID e HANNOR, 1970 ).

Granadas piropo cromīferas foram estudadas pela pri meira vez por NIXON et al. (1963) que analisaram diversos concen 
trados de kimberlitos da antiga Basutolāndia, região que corres ponde atualmente ao Estado de Lesotho. Nessa ocasião, NIXON e seus colaboradores chamaram a atenção para a influência excercida pelo crōmio em värias propriedades físicas. Por exemplo,eles observaram que o indice de refração e o parāmetro da cela unitāa ria aumentavam proporcionalmente com o incremento do teor de crō mio. Mas o ponto mais importante desse trabalho foi a observa ção de que algumas granadas continham mais crömio do que o neces särio para formar a molëcula de uvarovita $\mathrm{Ca}_{3} \mathrm{Cr}_{2}\left(\mathrm{SiO}_{4}\right)_{3}$. Da mesma forma, o teor de aluminio era insuficiente para balancear os teores de magnësio na formação da molëcula piropo $\mathrm{Mg}_{3} \mathrm{Al}_{2}\left(\mathrm{SiO}_{4}\right)_{3}$. NIXON e HORNUNG (1968) propuseram que os excessos de crômio e de magnēsio podiam se combinar e constituir a molēcula $\mathrm{Mg}_{3} \mathrm{Cr}_{2}\left(\mathrm{SiO}_{4}\right)_{3}$ que eles denominaram knorringuita em homenagem ao mineralogista 0 leg von Knorring. Simultaneamente, MEYER (1968) descreveu gra nadas semeihantes em diamantes da Africa, seguindo-se inümeros registros semelhantes (SOBOLEV et al., 1969; MEYER e SVISERO, $1973)$.

A presença ou não de knorringuita $\bar{e}$ a principal dife rença entre as crōmiopiropos e as piropo-almandinas. Os valores da Tabela 9, calr lados a partir das anälises da Tabela 8 apre sentam as porcf agens das molëculas constituintes das referidas granadas. Os 1 culos foram conduzidos obedecendo a sequencia de colocação dos lados da Tabela 9. Piropo e knorringuita são as principais molëculas das crōmiopiropos perfazendo juntas valores entre 78,0 a $88,0 \%$. Almandina varia em torno de $10,0 \%$, cabendo aos demais termos grossuläria, andradita e espessardita porcenta gens menores. 0 teor de $\mathrm{Cr}_{2} \mathrm{O}_{3}$ influi decisivamente na quantida de de knorringuita, que por sua vez guarda relações diretas com a molëcula piropo. Aumentando o teor de knorringuita diminui o teor de piropo, e vice-versa.

As piropo-almandinas, como o prōprio nome diz, são for madas essencialmente por esses dois termos que juntos somam apró ximadamente $80 \%$. Grossuläria e andradita participam da solução 
sölida em teores equivalentes, que ainda inclui proporções redu zidas de espessartita. REID e HANNOR (1970), GURNEY e SWITZER (1973), SOBOLEV (1974) e SWITZER (1975) registraram composições semelhantes em crómiopiropos kimberliticas de diversos locais.

A incorporação do crōmio na estrutura das crômiopiropos se faz às expensas do alumīnio. Este fato está bem eviden ciado pela Figura 16 que mostra a variação dos ōxidos $\mathrm{Al}_{2} \mathrm{O}_{3}$ e $\mathrm{Cr}_{2} \mathrm{O}_{3}$ entre as inclusões estudadas e granadas piropo cromîferas de origem kimberlitica incluindo: concentrados de kimberlitos (MCGETCHIN e SILVER, 1970; MCCALLUM e EGGLER, 1971; HORNUNG e NIXON, 1973; SOBOLEV et al., 1973; SOBOLEV, 1974; MEYER, 1975; SVISERO et al., 1977) e xenōlitos ultramäficos de kimberlitos (CARSWELL e DAWSON, 1970; BOYD, 1974a; BOYD e NIXON, 1975). GrOS so modo, a substituição do $\mathrm{Al}^{3+}$ pelo $\mathrm{Cr}^{3+}$ não acarreta modifica ções na estrutura cristalina das crómiopiropos que é igual a es trutura das piropos comuns (NOVAK e MEYER, 1970). As ünicas a terações são pequenas distorções resultantes das diferenças en tre os raios iōnicos do alumīnio e do crômio, mas que são per feitamente negligenciāveis.

Entre as propriedades fisicas, a cor, o indice de re fração e o parāmetro da cela unitäria sofrem variações conside räveis à medida que aumenta o teor de crömio na granada. HORNUNG e NIXON (1973) apōs correlacionarem a cor com a variação de crō mio, estabeleceram quatro grupos de cores principais: 1) verme Tha escura (piropos contendo de 1,0 a $2,0 \%$ de $\mathrm{Cr}_{2} \mathrm{O}_{3}$ ): 2) vinho $\left(2,0\right.$ a $7,0 \%$ de $\left.\left.\mathrm{Cr}_{2} \mathrm{O}_{3}\right) ; 3\right)$ violeta $\left(7,0\right.$ a $12,0 \%$ de $\left.\mathrm{Cr}_{2} \mathrm{O}_{3}\right)$, e 4) verde escura $\left(12,0\right.$ a $18,0 \%$ de $\left.\mathrm{Cr}_{2} \mathrm{O}_{3}\right)$. Os valóres mäximos de crōmio atē agora observados em granadas naturais continuam sen do aqueles estabelecidos por NIXON e HORNUNG (1968) e MEYER e SVISERO (1975) que encontraram $17,4 \%$ de $\mathrm{Cr}_{2} \mathrm{O}_{3}$ em piropos asso ciadas a kimberlitos e diamantes, respectivamente.

o indice de refração ē outra propriedade que sofre va riação, aumentando linearmente com o incremento de crömio na granada. Este fato estā bem evidenciado na Figura 17 atravēs de 


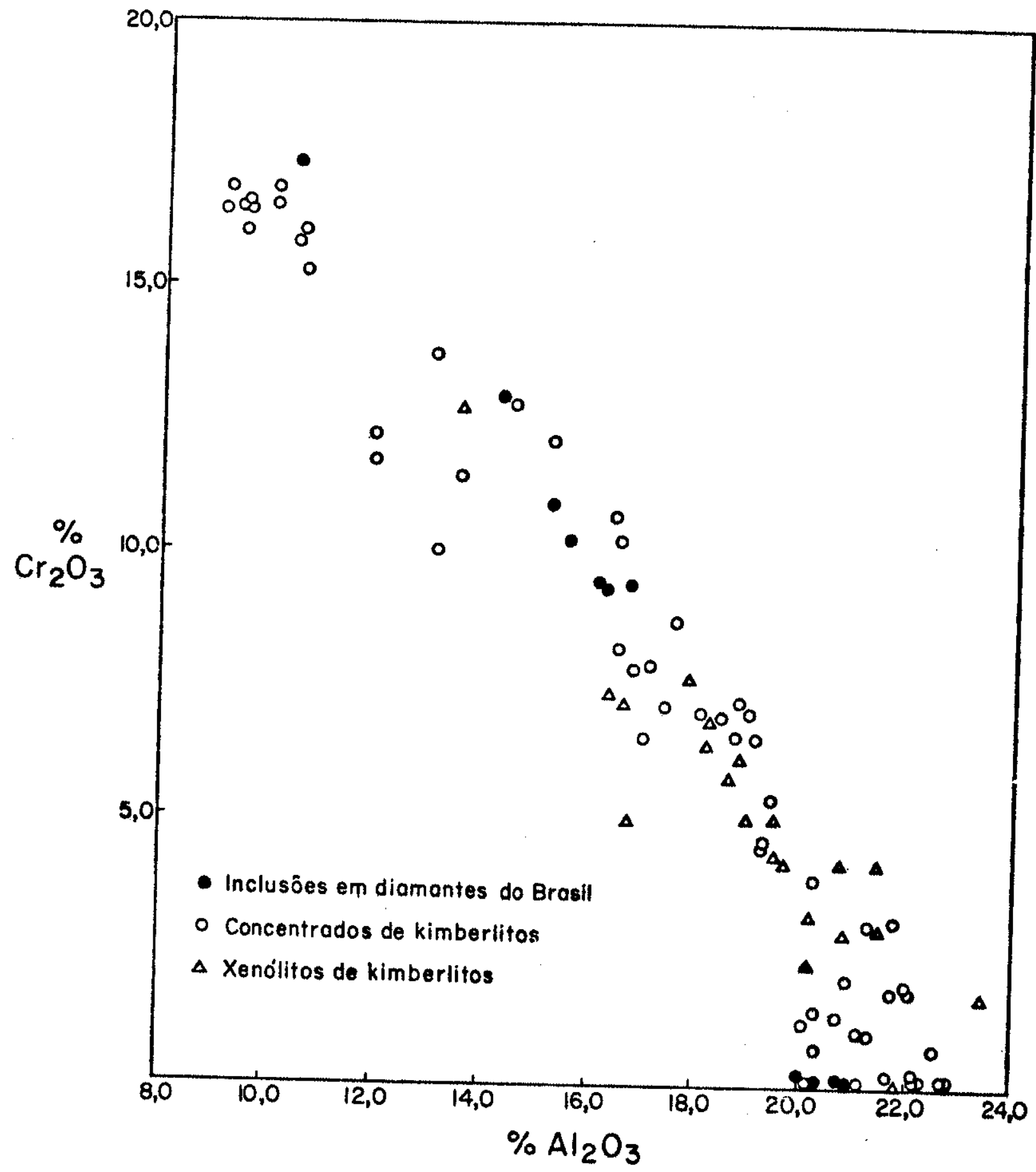

Figura 16 - Relação entre os teores de aluminio e crômio de granadas inclusas em diamantes do Brasil, comparadas com material equivalente consti tuinte de concentrados e xeinólitos de perfdotitos de natureza kim berlitica. Aumentando o teor de crimio, diminui o teor de alumínio. e vice-versa.Essa variação, aproximadamente linear, mostra que esses dois elementos se substituem na rede cristalina da granada. Dados comparativos extrafdos de MCGETCHIN e SILVER (1970), CARSWELL e DAWSON (1970), MCCALLUM E EGGLER (1971), HORNUNG E NIXON (1973), SOBO LEV et al. (1973),BOYD(1974a), SCBOLEV(1974), MEYER(1975),BOYD e NIXIN (1975), SVISERO et al. (1977). 


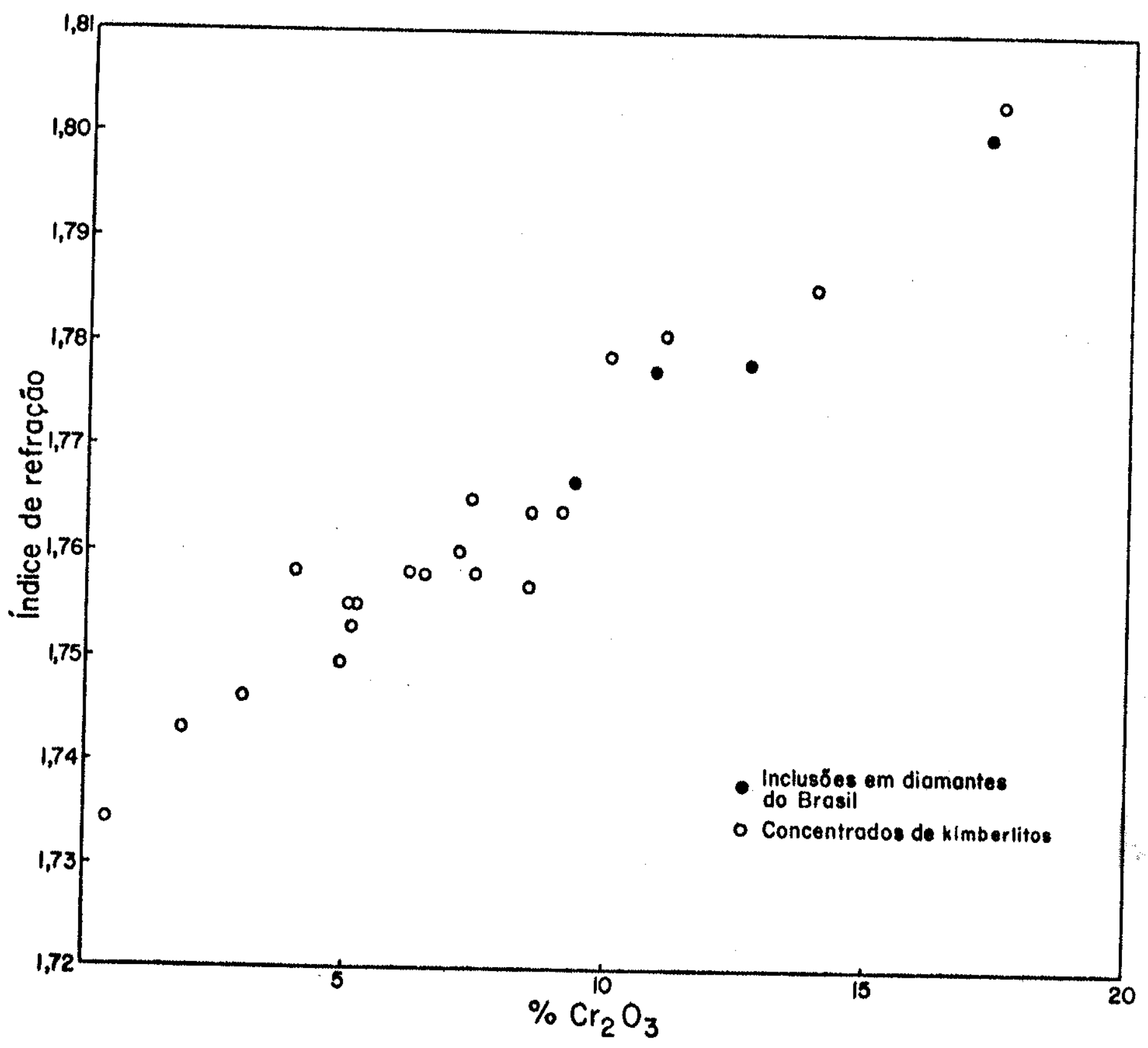

Figura 17 - Variação dos fndices de refração de granadas kimberlíticas em função dos seus respectivos teores de crómi.o. Os índices de refração aumentam. de forma aproximadamente linear; com o aumento do teor de crómio na granada. Dados comparativos extraidos de NIXON et al (1963); NIXON e HORNUNG (1968); SOBOLEV et al (1969); SOBOLEV (1970) a SOBOLEV $(1974)$. 
quatro granadas inclusas em diamantes brasileiros, e por grana das constituintes de concentrados de kimberlitos (NIXON et al., 1963; NIXON e HORNUNG, 1968) e de xenōlitos peridotiticos de kimberlitos (SOBOLEV et al., 1969a; SOBOLEV, 1970; SOBOLEV,1974). ocorre fato semelhante com o parämetro da cela unitäria (NIXON et al., 1963; ROST et al., 1975).

A sintese de granadas piropo contendo crömio foi ten tada inicialmente por COES (1955) que não obteve exito dada a formação de uvarovita no produto final. BYKOVA e GENSHAFT (1972) conduziram uma sērie de experiēncias visando a sintetizar grana das da sērie piropo-knorringuita. Submetendo proporções convenientes de $\mathrm{SiO}_{2}, \mathrm{Al}_{2} \mathrm{O}_{3}, \mathrm{MgO}$ e $\mathrm{Cr}_{2} \mathrm{O}_{3}$ a temperaturas entre 1200 e $1500^{\circ} \mathrm{C}$ e pressões de 30-80 kbars, eles lograram obter grana das contendo proporções de no mäximo $40 \%$ de knorringuita (Figu ra 26). Soluções sölidas contendo piropo e knorringuita em to das as proporções sō foram conseguidas recentemente por RINGWOOD (1977). Tanto BYKOVA e GENSHAFT (1972) quanto RINGWOOD efetuaram correlações entre a composição e algumas propriedades fisicas dos produtos sintetizados, confirmando a variação linear do indice de refração e do parāmetro da cela unitāria com o aumento do teor de crómio. BYKOVA et az.(1972) destacaram tam bëm a coloração verde escura dos produtos mais cromiferos por eles sintetizados.

CROMIOESPINELIO

Mineral pouco frequente em diamantes brasileiros, po dendo mesmo ser considerado uma inclusão rara. Em geral consti tui associações com olivina ou granada, mas nunca com piroxenios magnesianos ou cālcicos (MEYER e BOYD, 1972). A cor castá nha $\bar{e}$ uma das principais caracteristicas dos cromioespinēios, tornando possivel o seu reconhecimento pelo simples exame mi croscōpico. 


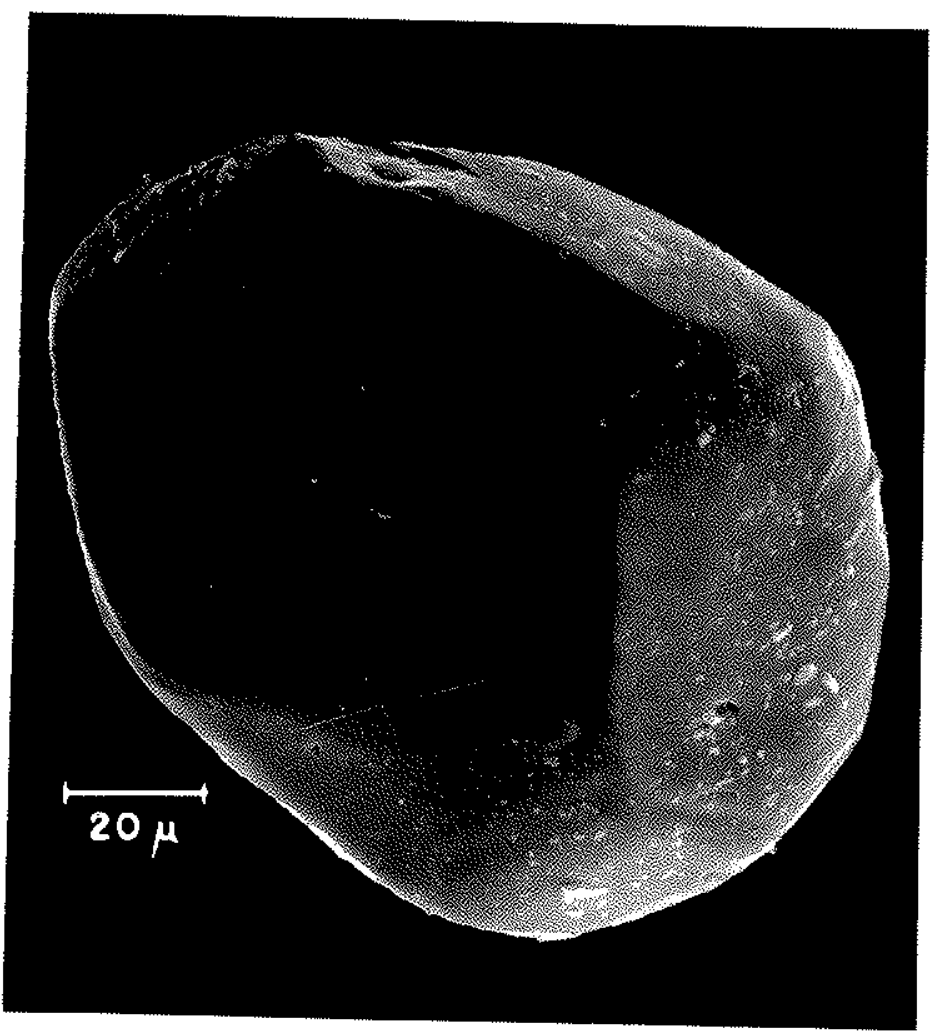

Micrografia eletrônica l3 - Cristal octaédrico de cromioespinélio combinado com faces de rombododecaedro. Aumento $700 x$. 
No interior do diamante, o cromioespinëlio

aparece sob a forma de cristais de häbitos variados sendo os mais cons pícuos o octaédrico e o tabular. Uma das inclusões estudadas estā ilustrada na Micrografia eletrōnica 13. Trata-se de um cristal octaēdrico constituído pela combinação de faces octaê dricas planas e faces rombododecaēdricas ligeiramente abauladas. Pode observar-se um certo grau de desproporcionamento no sent do da face rombododecaëdrica mais desenvolvida, o que equivale dizer que o crescimento foi mais acentuado segundo a direção $|110|$. Tais feições são por demais comuns em diamantes, o que permite supor que o hospedeiro controla, em parte, a morfologia das inclusões (SOBOLEV e BOTKUNOV, 1972).

As composições quīmicas de trēs cromioespinēios pro venientes dos garimpos de Minas Gerais, Mato Grosso e Parā ( Ta bela 1), estão apresentadas na Tabela 10. Em todas as anāiises, os valores de $\mathrm{FeO}$ e $\mathrm{Fe}_{2} \mathrm{O}_{3}$ foram calculados de modo a satisfazer a förmula geral dos espinēilios $A^{2+} B_{2}^{3+} 0_{4}$. As posições $A$ são ocupadas pelo ferro II. magnēsio, călcio e manganēs que no cro mioespinēlio participam de coordenações octaēdricas. Quanto às posições B, elas são ocupadas por elementos tetraedricamente co ordenados, a saber, o alumínio, o silî́cio, o titânio e o ferro III. Com relação às molēculas constituintes, as inclusões estú dadas são formadas essencialmente de cromioespinêlio cujos teo res variam entre 61,0 a $78,0 \%$. Os demais termos cromita, hercy nita, magnetita e galaxita, participam da composição em porcen tagens subordinadas (Tabela 11).

Repetindo o procedimento adotado em relação às demais inclusões, a Figura 18 compara em um diagrama de variação ter näria $\mathrm{Al}-\mathrm{Cr}-\mathrm{Fe}^{3+}$, crōmoespinēlios do Brasil e de outras local $\underline{\mathbf{j}}$ dades geogräficas. Observa-se uma vez mais que entre as inclú sões brasileiras e as descritas por MEYER e BOYD (1959, 1972), SOBOLEV E POKHILENKO (1975), SOBOLEV (1974) E MEYER E TSAI (1976).

Näo poderíamos deixar de ressaltar os teores altos de crōmio dos trēs espēcimes analisados, sō igualados por cromioes 
TABELA 10 - COMPOSIÇAO QUIMICA DE INCLUSOES DE CROMIOESPINELIO PRESENTES EM DIAMANTES DO BRASIL

$\begin{array}{lccc} & M G-50 \mathrm{~b} * & P A-20 \mathrm{a} & M T-64 \mathrm{~b} \\ \mathrm{SiO}_{2} & 0,32 & 0,34 & 0,21 \\ \mathrm{TiO}_{2} & 0,05 & 0,05 & 0,09 \\ \mathrm{Al}_{2} \mathrm{O}_{3} & 6,59 & 5,88 & 5,85 \\ \mathrm{Cr}_{2} \mathrm{O}_{3} & 63,63 & 65,53 & 64,03 \\ \mathrm{FeO} & 12,46 & 15,60 & 15,03 \\ \mathrm{MgO} & 16,24 & 12,73 & 14,29 \\ \mathrm{CaO} & 0,01 & 0,12 & 0,01 \\ \mathrm{MnO} & 0,15 & 0,36 & 0,06 \\ \text { Total } & 99,45 & 100,61 & 99,57\end{array}$

Nümero de cātions $(\times 1000)$ com base em 4 ätomos de oxigēnio

\begin{tabular}{|c|c|c|c|c|c|c|}
\hline Si & $10^{\circ}$ & \multirow{5}{*}{2000} & 11 & \multirow{5}{*}{2000} & 7 & \multirow{5}{*}{2000} \\
\hline $\mathrm{Ti}$ & 1 & & 1 & & 2 & \\
\hline$A 1$ & 254 & & 229 & & 228 & \\
\hline $\mathrm{Cr}$ & 1642 & & 1709 & & 1677 & \\
\hline $\mathrm{Fe}^{3+}$ & 93. & & 50 & & 86 & \\
\hline $\mathrm{Fe}^{2+}$ & $247^{\circ}$ & \multirow{4}{*}{1040} & 380 & \multirow{4}{*}{1019} & 330 & \multirow{4}{*}{1037} \\
\hline $\mathrm{Mg}$ & 789 & & 625 & & 705 & \\
\hline $\mathrm{Ca}$ & 0 & & 4 & & 0 & \\
\hline$M n$ & 4. & & 10 & & 2 & \\
\hline$\frac{\mathrm{Mg} \times 100}{\mathrm{Mg}+\mathrm{Fe}}$ & \multicolumn{2}{|c|}{76,2} & \multicolumn{2}{|c|}{62,2} & \multicolumn{2}{|c|}{68,1} \\
\hline
\end{tabular}

* Coexiste com olivina MG-50a 
TABELA 11 - PORCENTAGENS DAS MOLECULAS CONSTITUINTES DOS CROMIOESPINELIOS INCLUSOS EM DIAMANTES BRASILEIROS

\begin{tabular}{|c|c|c|c|}
\hline & $M G-50 b$ & $P A-20 a$ & $\mathrm{MT}-64 \mathrm{H}$ \\
\hline $\mathrm{CaAl}_{2}{ }^{\mathrm{O}} 4$ & 0,00 & 0,32 & 0,00 \\
\hline $\begin{array}{l}\mathrm{MnAl} 2_{4}{ }^{\circ} \\
\text { Galaxita }\end{array}$ & 0,35 & 0,87 & 0,17 \\
\hline $\begin{array}{l}\mathrm{MgCr}_{2}{ }^{\mathrm{O}} 4 \\
\text { Cromioespinēio }\end{array}$ & 77,95 & 61,06 & 68,54 \\
\hline $\begin{array}{l}\mathrm{FeCr}_{2} \mathrm{O}_{4} \\
\text { Cromita }\end{array}$ & 5,60 & 25,31 & 16,69 \\
\hline $\begin{array}{l}\mathrm{FeAl}_{2} \mathrm{O}_{4} \\
\text { Hercynita }\end{array}$ & 10,88 & 8,79 & 9.74 \\
\hline $\begin{array}{l}\mathrm{FeFe}_{2} \mathrm{O}_{4} \\
\text { Magnetita }\end{array}$ & 5,42 & 2,83 & 4,86 \\
\hline Total & 100,20 & 99,18 & 100,00 \\
\hline
\end{tabular}




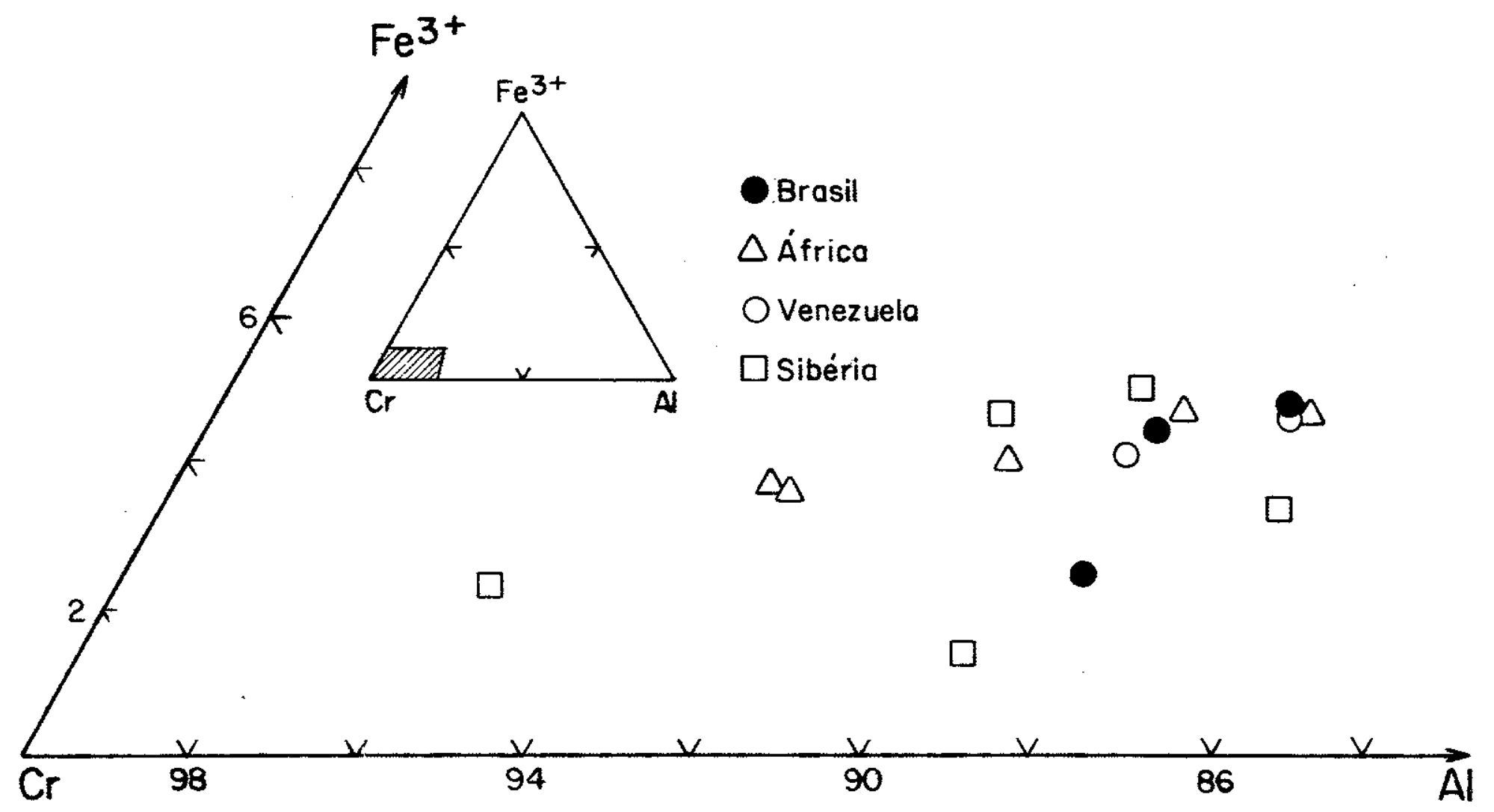

Figura 18 - Variação da composição química de cromioespinélios inclusos em diamantes do Brasil comparados com material equivalente da Uniäo Soviética (Sibéria), África (Gana, Serra Leoal e Venezuela. As inclusães apresentam variação limitada e caracterizamse pelo acentuado enriquecimento em crómio. Dados comparativos extraidos de MEYER e BOYD (1969, 1972); SOBOLEV (1974), SOBOLEV e POKHILENKO (1975) e MEYER e TSAI(1976). 


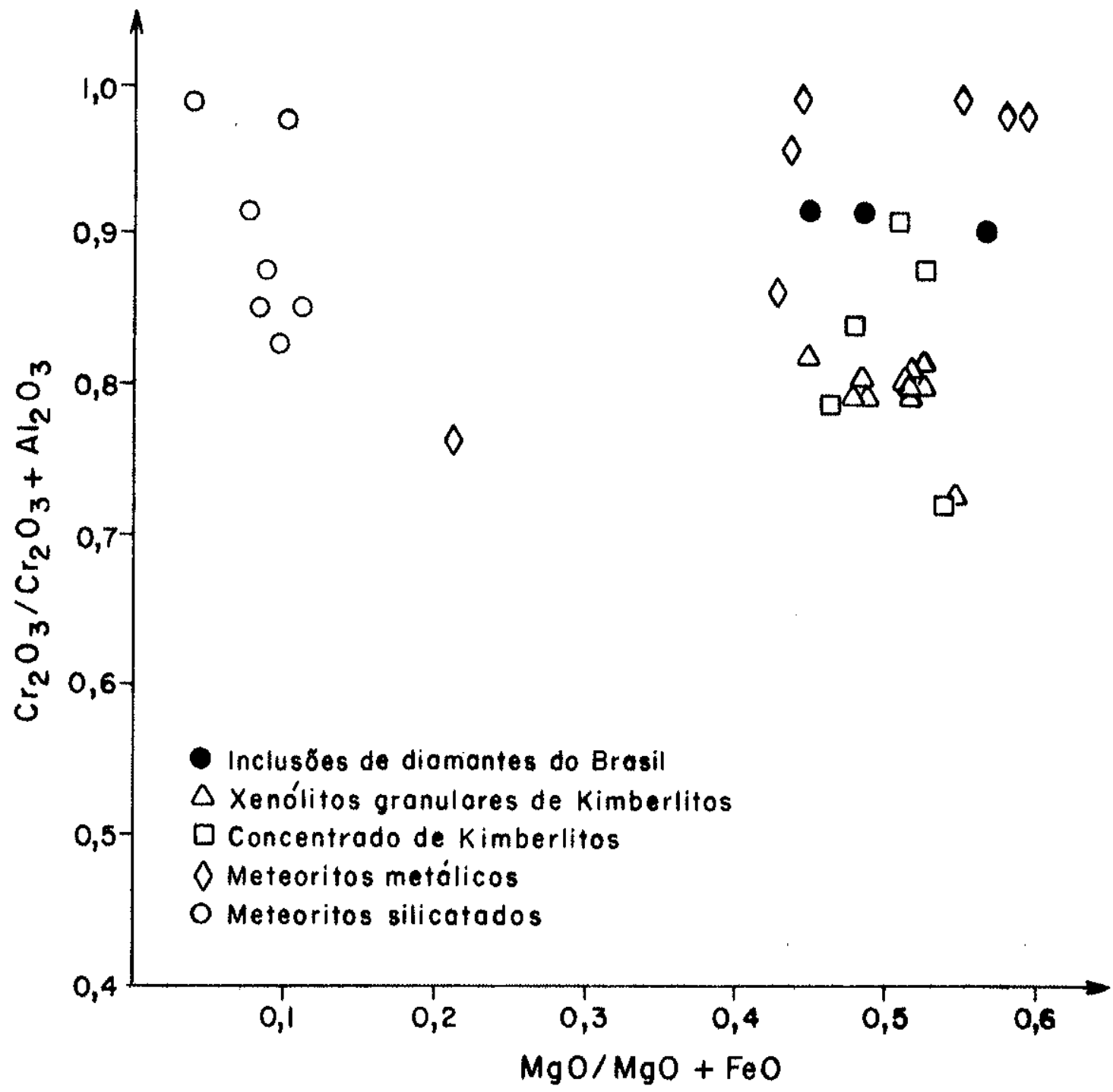

Figura 19 - Variação daṣ razões $\mathrm{Cr}_{2} \mathrm{O}_{3} / \mathrm{Cr}_{2} \mathrm{O}_{3}+\mathrm{Al}_{2} \mathrm{O}_{3}$ e $\mathrm{MgO} / \mathrm{MgO}+\mathrm{F} 8 \mathrm{O}$ de cromioespinélios inclusos em dlamantes do Brasil comparados com cromioespinélios de natureza kimberlfti ca e meteoritica. observa-se que as inclusões dos diamantes estudados são semelhantes aos cromioespinélios dos Iherzolitos granulares, o que vêm reforçar a hipótese de uma origem comum para esses dois tipos de mate riais. Quanto ao materlal meteorítico, as inclusões as semelham-se aos cromloespinélios de meteoritos metálfcos. Dados comparativos extraídos de BUNCH(1967,1970); BOYD E NIXON(1972); NIXÓN \& BOYO(1973); BLOOMER \& NIXON (1973); KRESTEN (1973); SOBOLEV (1974). 
pinēlios de natureza meteorîtica. (BUNCH et az., 1967, 1970). Es se fato estā bem evidente na Figura 19 que mostra a variação das razões $\mathrm{Cr}_{2} \mathrm{O}_{3} / \mathrm{Cr}_{2} \mathrm{O}_{3}+\mathrm{Al}_{2} \mathrm{O}_{3}$ e MgO/MgO+FeO das inclusões estudadas comparadas com cromioespinēlios de xenölitos de lherzolitos gra nulares associados a kimberlitos (BOYD e NIXON, 1972; NIXON e BOYD. 1973) concentrados de kimberlitos (BLOOMER e NIXON, 1973; KRESTEN, 1973; SOBOLEV, 1974), e de meteoritos (BUNCH et al. $(1967,1970)$. As inclusões são ligeiramente mais ricas de crô mio do que os xenölitos granulares, mas se comparam a eles em termos da razão $\mathrm{MgO} / \mathrm{Mg} 0+\mathrm{FeO}$. Correlacionadas com crömioespine lios de origem meteorítica, as inclusões descristas em diaman tes brasileiros apresentam semelhanças maiores com os consti tuintes de meteoritos metālicos.

E digno de nota a ausēncia do crómioespinëlio entre os xenōlitos de lherzolitos estriados descritos por NIXON e BOYD (1973) e BLOOMER e NIXON (1973). Esse fato pode ser da mais alta importancia no que diz respeito ä origem das inclusões. Diversas evidências químicas discutidas nos capitulos anterio res ressaltaram värios tipos de semelhanças entre as inclusões e seus respectivos componentes de xenōlitos granulares e estria dos de kimberlitos. Entretanto, a ausēncia de crömioespinēilo entre os lherzolitos estriados poderia, talvez, indicar uma se melhança maior das inclusões com os lherzolitos granulares do que com os Therzolitos estriados. Relações desse tipo voltarão a ser discutidas no capĩtulo referente a origem das inclusões.

RUTILO

0 rutilo ē uma inclusão rara em diamante, tendo sido identificado pela primeira vez por MEYER e BOYD (1968). Poste riormente, HARRIS (1968), GURNEY et al. (1969), e SOBOLEV et al. (1972) observaram esse mineral em diamantes da Africa e União 
Soviëtica. No decorrer deste trabalho determinamos dois exempla res associados a diamantes de Mato Grosso e Goiās (Tabela 1).Eles foram identificados inicialmente por meio de anāilses químicas, mas confirmados realmente por difração de raios $x$.

E fato bem conhecido que $\mathrm{O}^{\mathrm{T}} \mathrm{O}_{2}$ se apresenta na natu reza sob a forma de trēs polimorfos distintos, respectivamente, rutilo, anatäsio ebrookita (DEER et al., 1967). Nessas condi ções, a anālise quĩmica não e suficiente para caracterizar qua quer uma das trēs fases, tornando-se necessärio o recurso de outra tēcnica física para completar a identificação. Recorremos à difração de rajos $x$, e por meio de diagramas de precessão,com provamos com segurança que o polimorfo de $\mathrm{TiO}_{2}$ associado ao dia mante $\vec{e}$ de fato o rutilo. A Fotografia $2 \vec{e} 0$ diagrama de pre cessão de uma das inclusões estudadas (MT-16a). A rede recipró ca, construĩda a partir do referido diagrama está reproduzida na Figura 20. De posse desses elementos, foi possivel calcular os parāmetros da cela unitäria cujos valores são $a_{0}=4,59 \AA$ e $c_{0}=2,95 \AA$. 0 grupo espacial, por sua vez, $\bar{e} P 42_{2} \mathrm{~mm}$ confirman do que as inclusões analisadas são de fato rutilo.

as dois espēcimes são muito semelhantes, exibindo cor castanha avermelhada, transparēncia moderada, idiomorfismo perfeito e dimensões avantajadas em relação às demais inclusões. Um deles, ilustrado na Micrografia eletrōnica 14, exibe häbito prismätico típico sendo evidente o alongamento segundo o eixo cristalogräfico c. 0 cristal é constituỉdo por dois prismas te tragonais bem desenvolvidos e terminado em uma das extremidades por faces de bipirämide tetragonal. Algumas microestruturas ob servadas sobre as faces prismäticas (Microscopia eletrōnica 15) mostram padrão regular e concordante com a simetria pontual do rutilo $4 / \mathrm{mmm}$.

A Tabela 12 apresenta as anälises químicas dos ruti los inclusos em diamantes do Brasil. Como os dados o demons tram, os rutilos são prōximos da estequiometria química sendo constituidos essencialmente por $\mathrm{TiO}_{2}$ cujos teores variam entre 


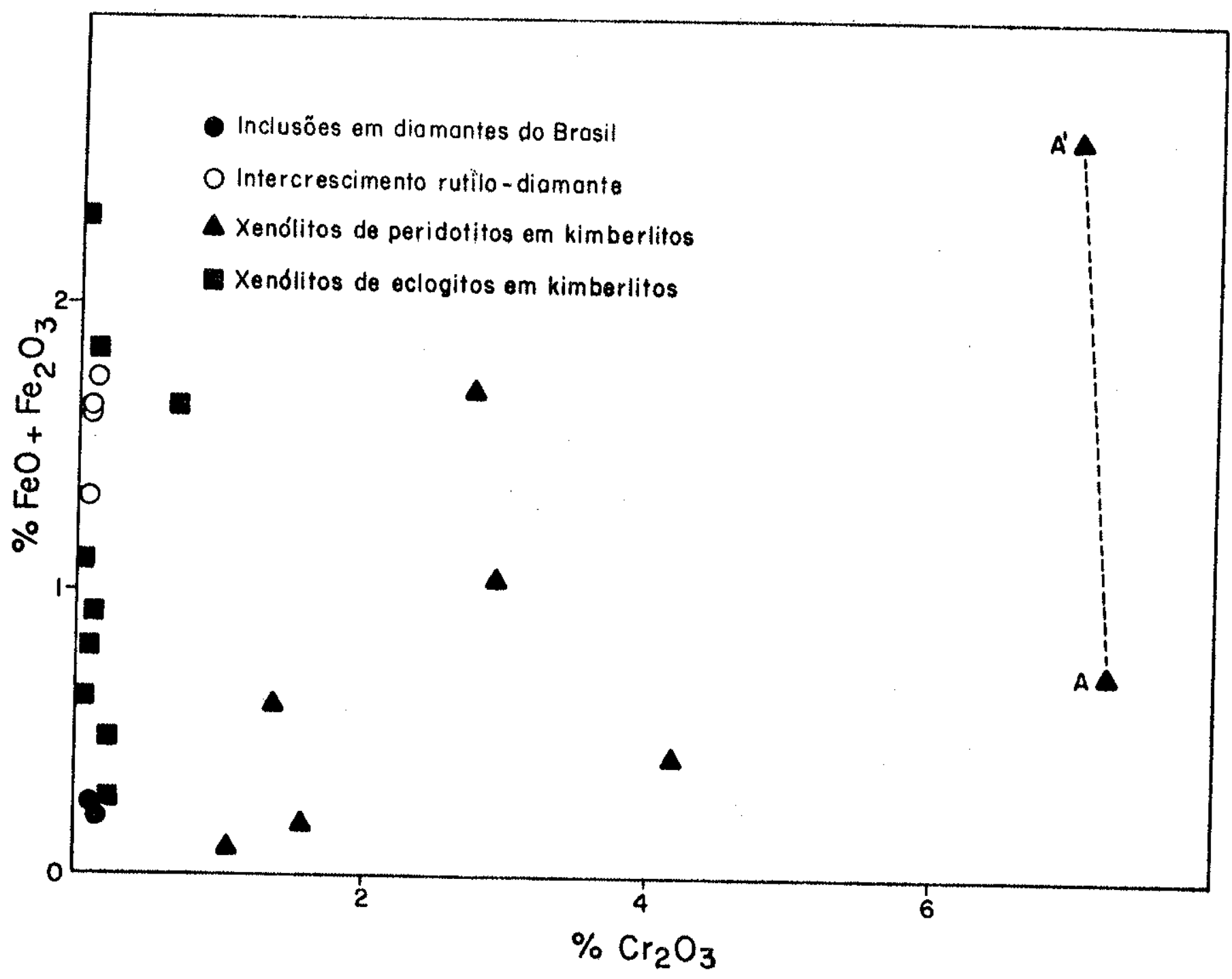

Figura 20 - Variação dos teores de $\mathrm{Cr}_{2} \mathrm{O}_{3}$ e $\mathrm{FeO}+\mathrm{Fe}_{2} \mathrm{O}_{3}$ de rutilos inclusas em diamantes do Brasil, comparados com intercrescimentos cristalinos entre diamantes e rutilos da União Soviética, e com rutílos constituintes de xenóli tos de peridotitos e eclogitos de natureza kimberlfti ca. Os pontos $A$ e $A^{\prime}$ indicam, respectivamente, a composição química no nücleo e na borda de um rutilo consti tuinte de lherzolito proveniente do kimberlito Bulfontein. Africa do sul. As duas inclusões associadas a dia mantes brasileiros são desprovidas de crômio: projetam - se dentro do campo definido pelos rutilos de natureza eclogitica,e dessa forma, diferenciam-se dos demais rut1los de natureza ultramáfica cujos teores de $\mathrm{Cr}_{2}{ }^{3}$ quase alcançam $8,0 \%$. Dados camparativos extraidos $2{ }^{3}$ SOBOLEV et al(1971), COX et al(1973); SOBOLEV (1974); HARTE E GURNEY(1975); SMITH E DAWSON(1975); ELTHON \& RI DLEY (1977). 


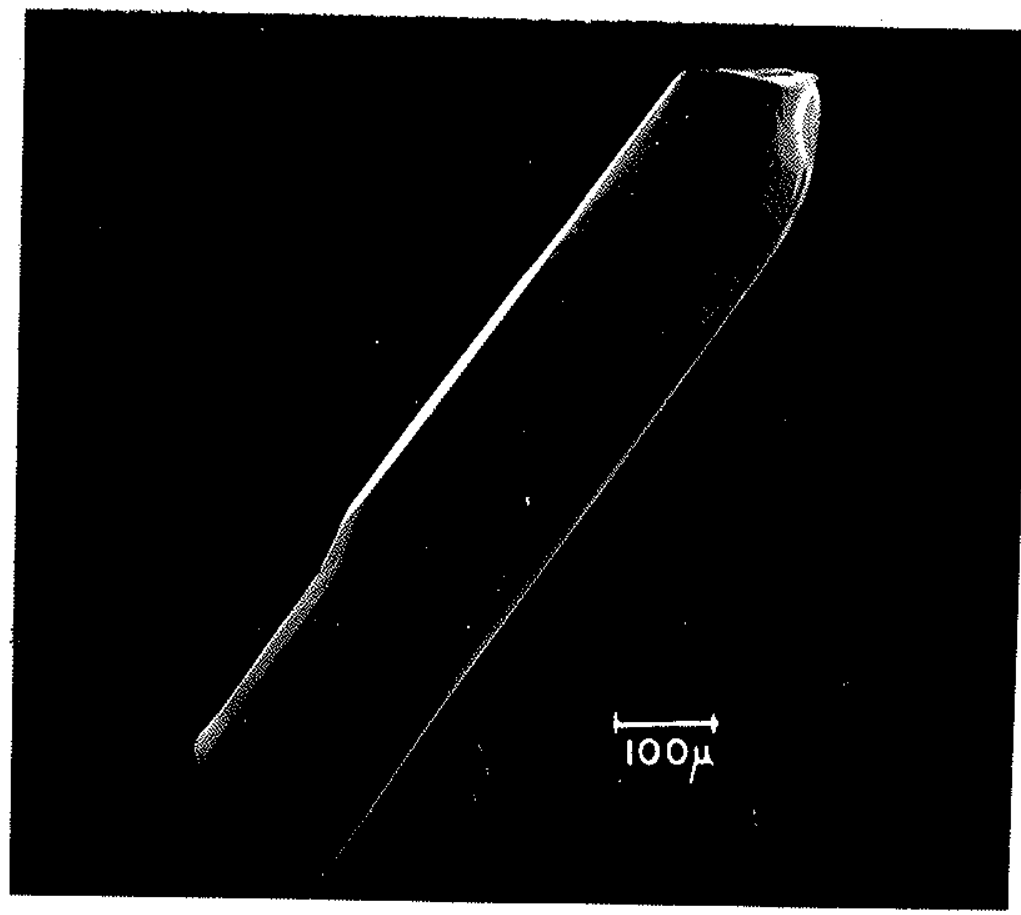

$-84 \cdots$

Micrografia eletrônica 14 - Rutilo de häbito prismático com acen tuado alongamento segundo o eixo cristalográfico c. Aumento $100 x$.

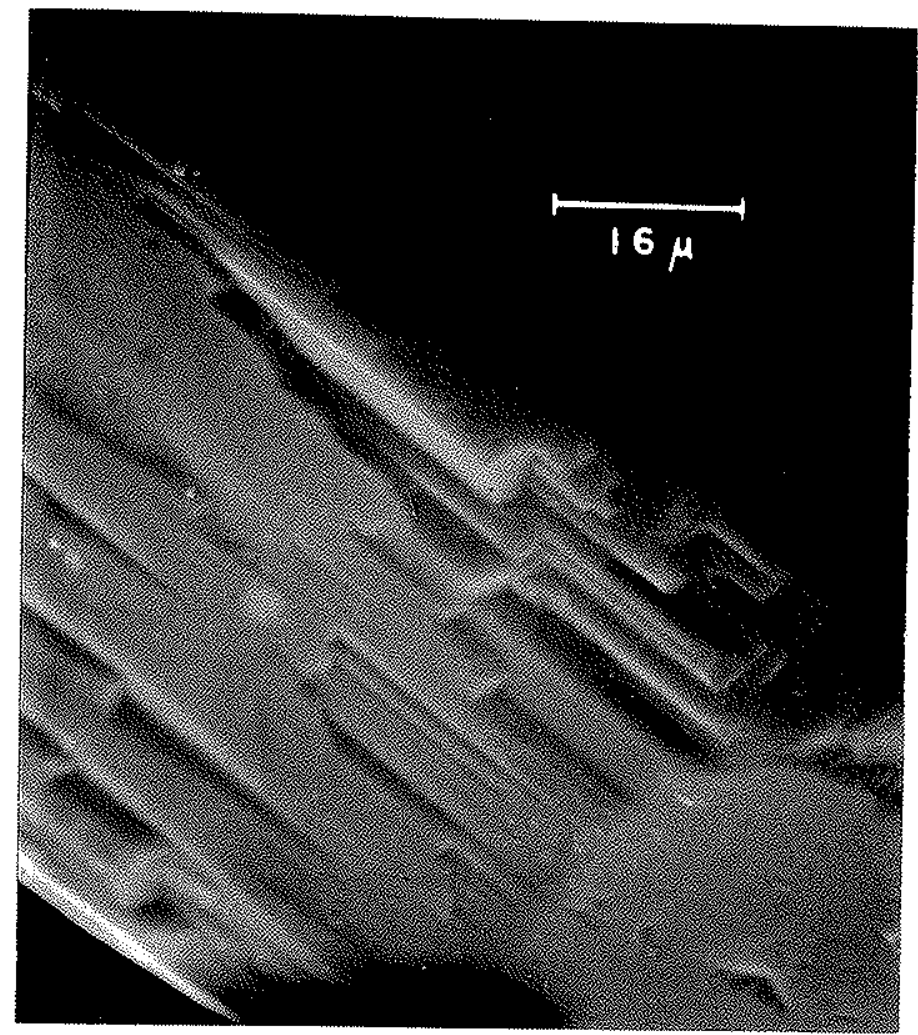

Micrografia eletrônica 15 - Microestruturas presentes nas faces prismáticas do cristal anterior. Aumento $1.200 \times$. 
TABELA 12 - COMPOSIÇÃO QUIMICA DE INCLUSÕES DE RUTILO EM DIAMANTES DO BRASIL

$\begin{array}{lrr} & M T-16 \mathrm{a} & \mathrm{G} 0-18 \mathrm{a} \\ \mathrm{SiO}_{2} & 0,09 & 0,06 \\ \mathrm{TiO}_{2} & 99,64 & 99,80 \\ \mathrm{Al}_{2} \mathrm{O}_{3} & 0,27 & 0,30 \\ \mathrm{Cr}_{2} \mathrm{O}_{3} & 0,11 & 0,16 \\ \mathrm{Fe} 0 & 0,24 & 0,26 \\ \mathrm{MgO} & 0,06 & 0,02 \\ \mathrm{CaO} & <0,01 & <0,01 \\ \mathrm{MnO} & <0,01 & <0,01 \\ \text { Total } & 100,41 & 100,60\end{array}$

Nūmero de cātions $(x 1.000)$ baseado em 2 àtomos de oxigênio

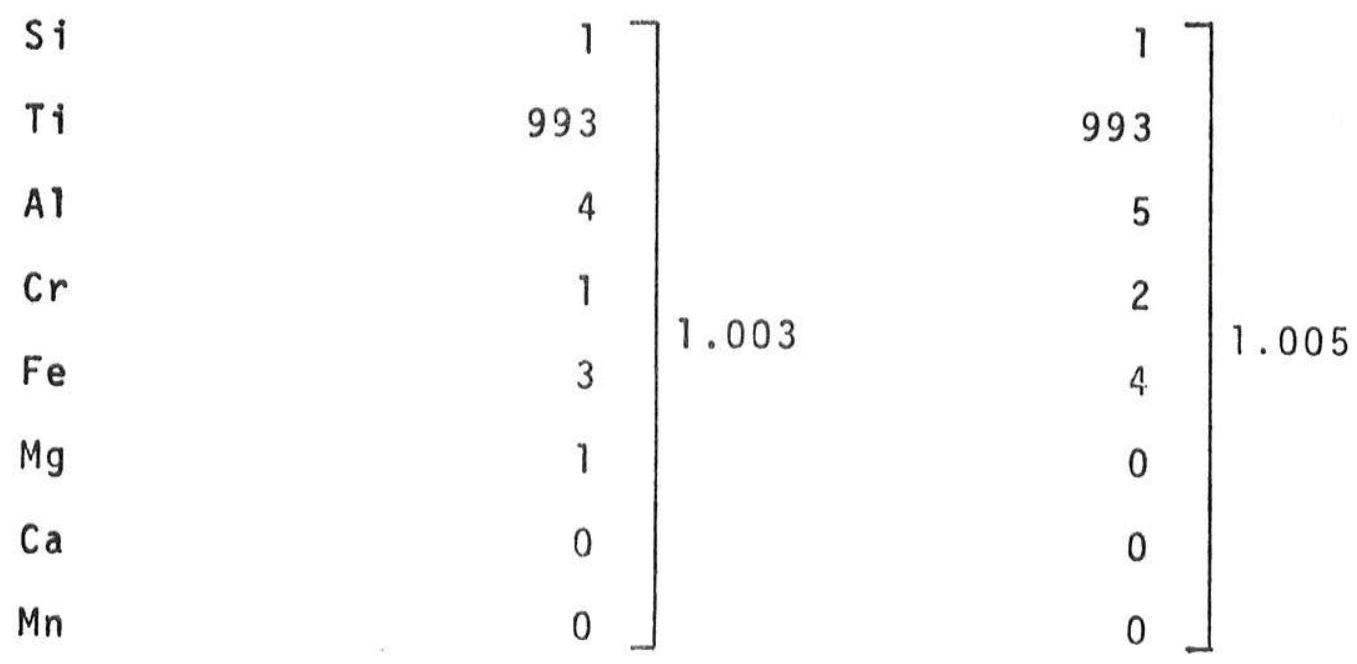




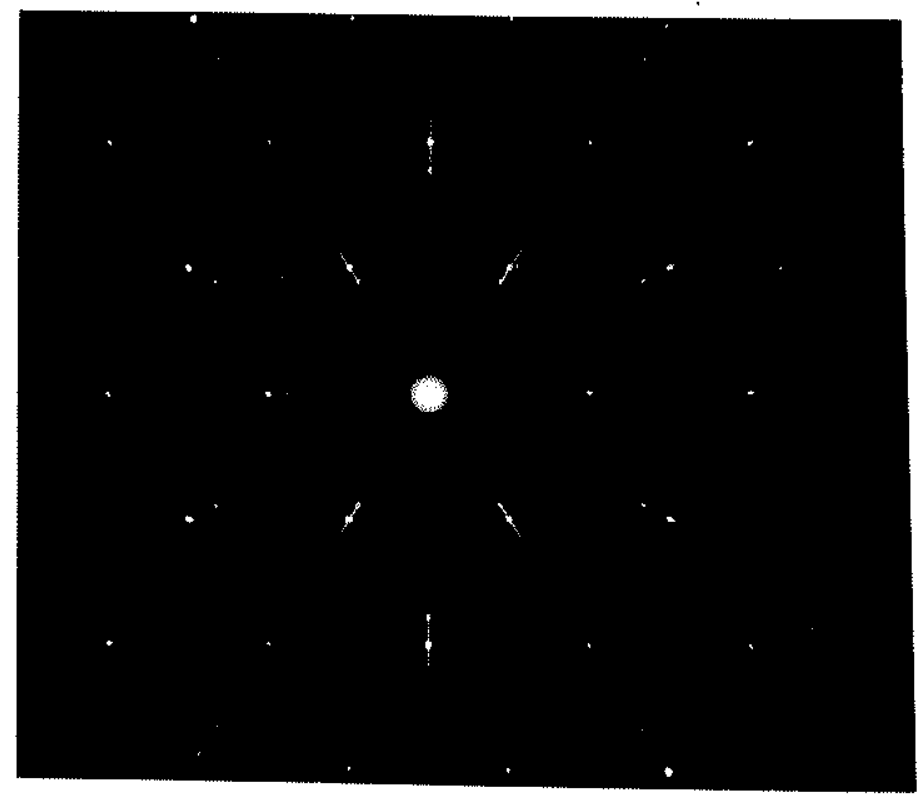

Fotografia 2 - Diagrama de precessão de uma inclusão de rutilo obtida com o feixe de raios $x$ incidindo perpendi cularmente à face (100) da inclusão. Radiação branca de molibdênio, $1 / 2$ hora de exposição.

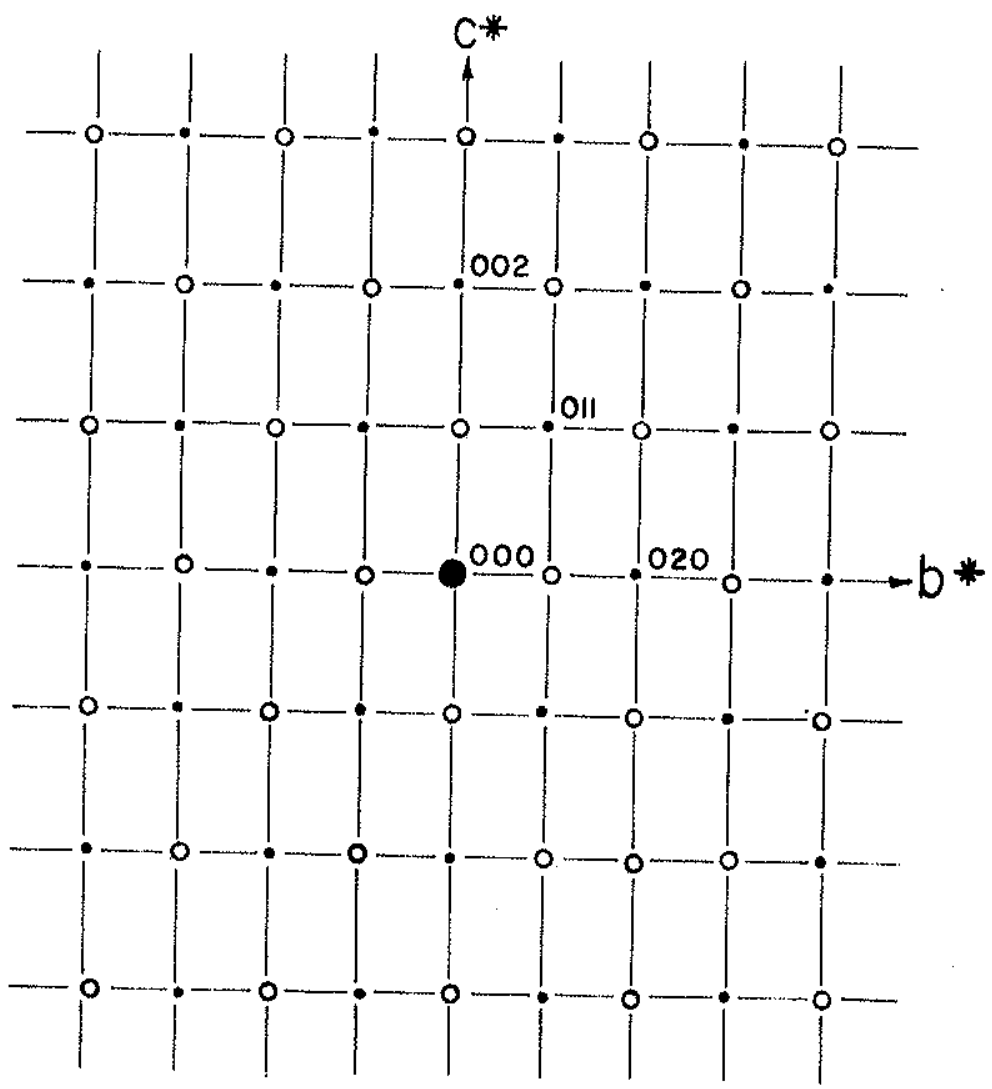

Figura 21 - Rede reciproca de uma das inclusões de rutilo, construida a partir do diagrama de precessão da fótografia 2 . 
$99,6 \%$ a $99,8 \%$. Os elementos subordinados perfazem menos de $0,8 \%$ em peso e incluem $\mathrm{Si}, \mathrm{Al}, \mathrm{Cr}, \mathrm{Fe}, \mathrm{Mg}, \mathrm{Ca}$ e $\mathrm{Mn}$.

A natureza eclogitica das inclusões de rutilo foi cons tatada por GURNEY et ai. (1969) ao identificarem esse mineral em diamantes associados a xenólitos de eclogitos provenientes do kimberlito Finsch, Africa do Sul. Esse kimberlito adquiriu noto riedade nos ūttimos anos em virtude dos seus diamantes conterem clinopiroxênios em quantidade maior do que todos os demais lo cais de ocorrência de diamante conhecidos.

A Figura 21 compara os conteüdos de $\mathrm{Cr}_{2} \mathrm{O}_{3}$ e $\mathrm{FeO}$ (ferro total) dos rutilos identificados nos diamantes brasileiros com rutilos de origens diversas. A referida Figura inclui intercres cimentos cristalinos entre o diamante e o rutilo (SOBOLEV et al., 1972a; SOBOLEV, 1974), e, rutilos constituintes de materiais kim berliticos diversos incluindo peridotitos (COX et al., 1973; HARTE e GURNEY, 1975; ELTHON e RIDLEY, 1977) e eclogitos (SMITH e DAWSON, 1975). Tanto os rutilos associados a diamante quanto os rutilos de xenólitos de eclogito, caracterizam-se por conte rem teores variāveis de ferro ao lado de valores quase desprezi veis de crômio. Dessa forma, eles se diferenciam facilmente dos rutilos de xenōlitos ultramäficos cujos teores de crômio, alëm de variāveis, podem alcançar quase $8,0 \%$ de $\mathrm{Cr}_{2}{ }_{2}{ }_{3}$.

\section{ZIRCAO}

0 registro de MEYER e SVISERO (1975) relativo a ocor réncia de zircão em diamantes brasileiros continua sendo o ünico caso conhecido na literatura. Embora o zircão não seja realmen te um mineral frequente em kimberlitos, alguns corpos podem con tê-10 em grande abundância como ocorre por exemplo com certos kim berlitos da URSS (KHARKIV et al., 1972) e do Brasil (DAVIS,1977). Uma solução seria investigar diamantes de kimberlitos que se sou besse,"a priori", conter zircão entre seus componentes princí pais. 


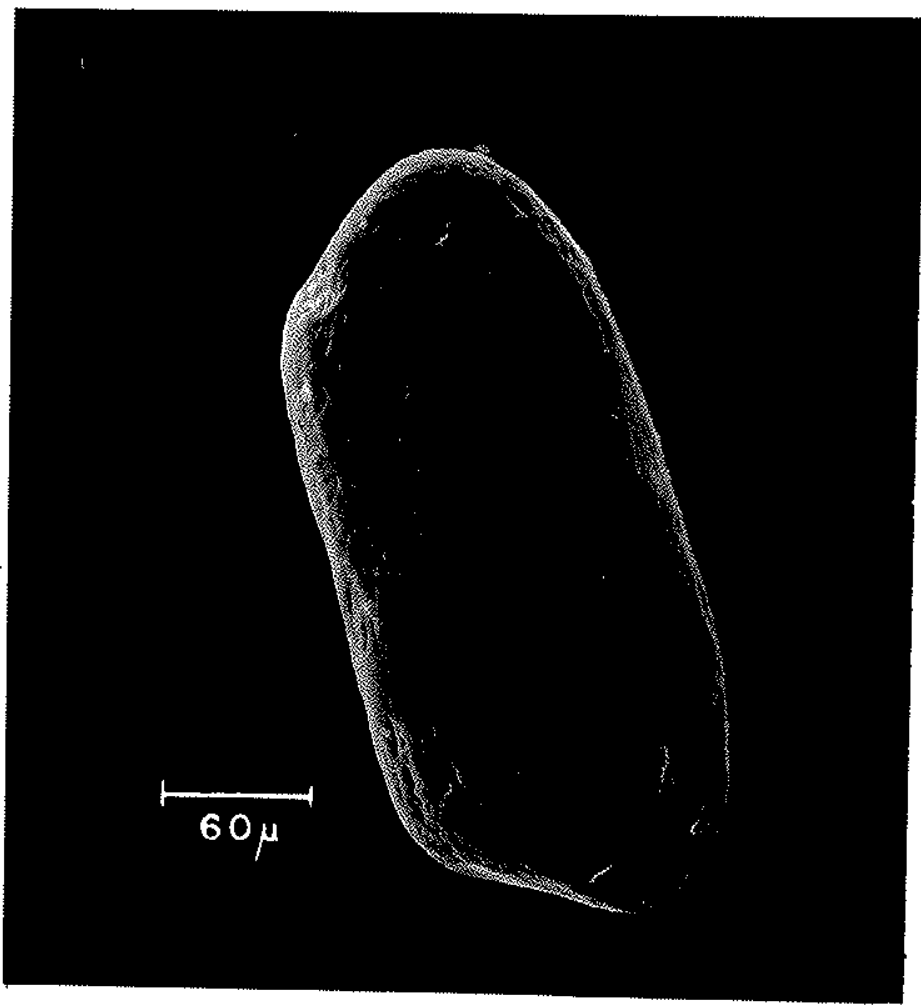

Micrografia eletrônica 16 - Cristal de zircão prismático a biterminado com a superfície repleta de irregularidades. Aumento $250 \mathrm{x}$. 
Esse programa serā certamente desenvolvido nos prōximos anos, de vez que uma das recomendações da Conferēncia Internacional sobre Kimberlitos realizada em Santa Fë, Estados Unidos da América diz respeito a anälise estatistica da frequencia dos minerais asso ciados ao diamante.

Os zircões identificados neste trabalho apresentam trans parēncia acentuada, cor amarela palha e häbito prismätico. exemplar ilustrado na Micrografia eletrōnica 16 caracteriza-se pelo abaulamento acentuado das suas faces e arestas; além disso, possui a superfīcie repleta de sulcos e cavidades que só pode riam ter sido produzidos por processos de corrosão. Admite-se, atualmente que a cristalização do diamante ē acompanhada por fa ses de dissolução graças ao acümulo de $\mathrm{CO}_{2}$ e outros volāteis,cuja ação ē favorecida pelas elevadíssimas pressões existentes no man to superior (BOYD e NIXON, 1973; MacGREGOR e BASU, 1974). Essas substāncias atuam sobre o diamante imprimindo feições peculiares em sua morfologia externa como häbitos transicionais, faces e arestas curvas (SVISERO, 1971), e da mesma forma, poderiam produ zir nas inclusões abaulamentos, sulcos, cavidades e outras estrú turas impossiveis de serem explicadas, admitindo-se um processo de cristalização normal.

Do ponto de vista químico, os dois espēcimes são tạn bëm semelhantes sendo constituidos essencialmente de $\mathrm{ZrO}_{2}$ e $\mathrm{SiO}_{2}$ (Tabela 13). Entre os elementos subordinados registramos teores reduzidos de $\mathrm{Al}$, $\mathrm{Fe}, \mathrm{Ca}$, e $\mathrm{Mn}$; e valores de Ti, Cr, e Mg ainda menores situados abaixo do limite de resolução do aparelho.

Entre as inclusões do diamante, provavelmente, 0 zir cão e a fase menos conhecida. 0s dados químicos disponiveis são insuficientes para caracterizar adequadamente essa inclusão, de modo que a sua origem ainda $\bar{e}$ um problema desconhecido. 
TABELA 13 - COMPOSIÇAO QUIMICA DE INCLUSOES DE ZIRCAO EM DIAMANTES DO BRASIL

$\begin{array}{lrr} & \mathrm{RO}-61 \mathrm{a} & \mathrm{MT}-30 \mathrm{a} \\ \mathrm{SHO}_{2} & 30,33 & 30,97 \\ \mathrm{TiO}_{2} & <0,01 & 0,03 \\ \mathrm{Al}_{2} \mathrm{O}_{3} & 0,03 & <0,01 \\ \mathrm{Cr}_{2} \mathrm{O}_{3} & <0,01 & <0,01 \\ \mathrm{FeO} & 0,06 & 0,01 \\ \mathrm{MgO} & <0,01 & <0,01 \\ \mathrm{CaO} & 0,03 & 0,01 \\ \mathrm{MnO} & 0,04 & 0,02 \\ \mathrm{ZrO} & 69,04 & 69,64 \\ \mathrm{Total}_{2} & 99,53 & 100,69\end{array}$

Nümero de cätions $(x 1.000)$ baseado em 2 ātomos de oxigênio

\begin{tabular}{|c|c|c|c|}
\hline$S i$ & $947^{\circ}$ & & 953 \\
\hline$T \mathfrak{i}$ & 0 & & 1 \\
\hline A) & 1 & & 0 \\
\hline $\mathrm{Cr}$ & 0 & & 0 \\
\hline $\mathrm{Fe}$ & 1 & 2.002 & 0 \\
\hline $\mathrm{Mg}$ & 0 & & 0 \\
\hline $\mathrm{Ca}$ & 1 & & 0 \\
\hline$M n$ & 1 & & 1 \\
\hline $\mathrm{Zr}$ & 1.051 & & 1.045 \\
\hline
\end{tabular}


I LMEN ITA

Inclusão rara, contrastando com a abundāncia desse mi neral em kimberlitos de todas as partes do munto (FRANTSESSON, 1970; FRICK, 1973; MEYER, 1975; SVISERO et al., 1977). As ilme nitas kimberlíticas apresentam-se revestidas por uma película amarela de leucoxēnio proveniente da alteração do mineral. In ternamente são negras e de brilho metālico intenso. Sendo relá tivamente resistentes ao intemperismo químico, a ilmenita cons titui juntamente com a granada piropo rica em crômio, os dois mais importantes minerais-indices na prospecção de kimberlitos.

A principal característica das ilmenitas provenientes de kimberlitos são os teores altos de $\mathrm{MgO}$ e $\mathrm{Cr}_{2} \mathrm{O}_{3}$ cujos valores variam entre 4,0 a $16,0 \%$, e entre 0 a $8,0 \%$, respectivamente (MITCHELL, 1973; HAGGERTY, 1975). Contudo, as inclusões por nōs identificadas são quase desprovidas de crōmio e magnésio, dois elementos constantes e característicos de ilmenitas kimber 1îticas. Trata-se de uma observaçäo aparentemente enigmātica tendo em vista o que se conhece sobre ilmenitas constituintes de kimberlitos e de nódulos ultramáficos associados a kimberlitos. Lamentavelmente, esses resultados não podem ser ainda devidamen te interpretados face a inexistēncia de dados equivalentes na literatura geolögica.

A Micrografia eletrōnica 17 mostra uma das quatro. i1 menitas identificadas em diamantes brasileiros (Tabela 1). 0 re ferido cristal apresenta cor negra, brilho metālico a submetāl co, hābito prismātico e suas superfícies são nitidamente irregu lares.

As anālises quỉmicas correspondentes às ilmenitas in clusas em diamantes do Brasil estão reunidas na Tabela 14.Todas as quatro amostras são constituỉdas essencialmente de $\mathrm{TiO}_{2}$ e Fe0, sendo os teores desses dois ōxidos quase uniformes e cons tantes. Sîlicio, alumīnio crōmio, magnésio, cālcio e manganês 


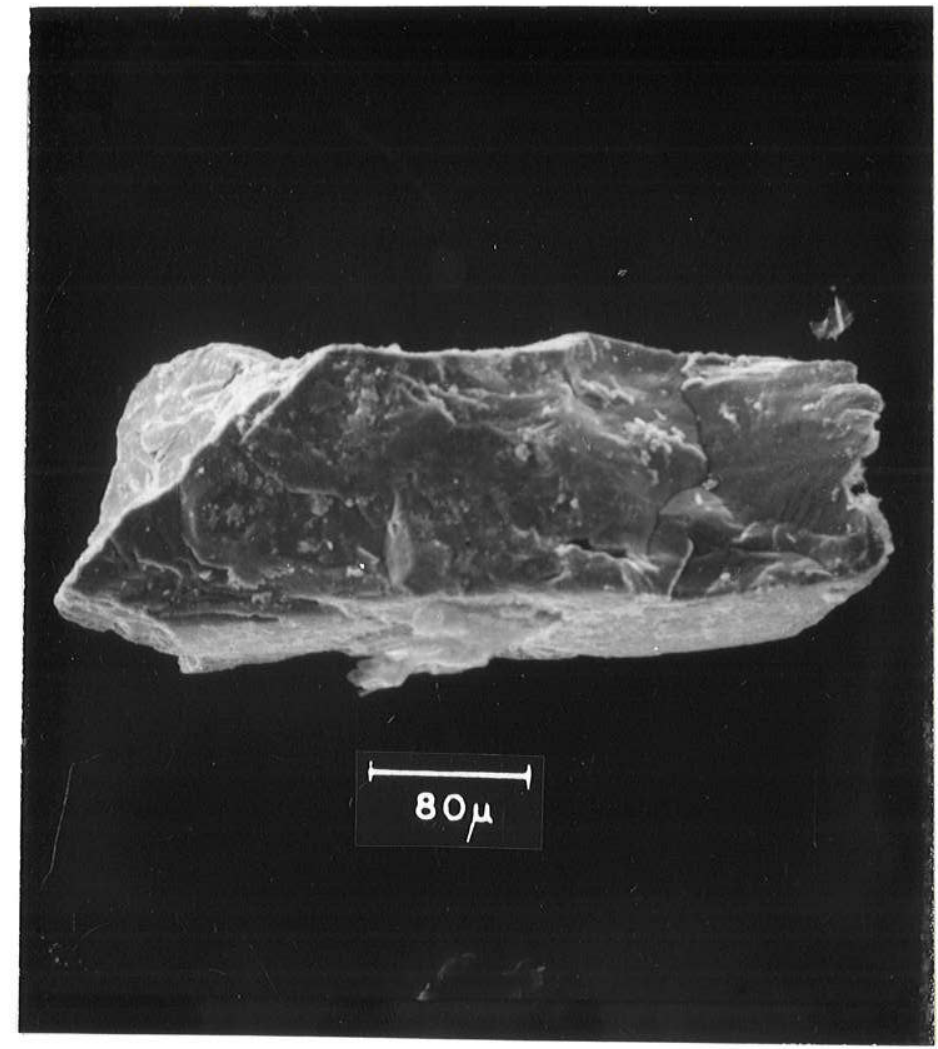

Micrografia eletrônica 17 - Ilmenita prismática contendo irregularidades na superfície. Aumento $200 \times$. 
TABELA 14 - COMPOSIÇAO QUTMICA DE INCLUSOES DE ILMENITA PRESENTES EM DIAMANTES DO BRASIL

$\begin{array}{lcccr} & M T-10 \mathrm{a} & \mathrm{MT}-10 \mathrm{~b} & \mathrm{BA}-19 \mathrm{a} & \mathrm{G}-49 \mathrm{a} \\ \mathrm{SiO}_{2} & 0,18 & 0,22 & 0,12 & 0,16 \\ \mathrm{TiO}_{2} & 50,45 & 50,17 & 51,94 & 51,47 \\ \mathrm{Al}_{2} \mathrm{O}_{3} & 0,22 & 0,15 & 0,21 & 0,36 \\ \mathrm{Cr}_{2} \mathrm{O}_{3} & 0,03 & 0,03 & <0,01 & 0,04 \\ \mathrm{Fe} 0 & 47,38 & 47,95 & 47,57 & 47,60 \\ \mathrm{MgO} & 0,11 & 0,16 & 0,14 & 0,14 \\ \mathrm{CaO} & 0,07 & <0,01 & 0,03 & <0,01 \\ \mathrm{MnO} & 0,73 & 0,74 & 0,64 & 0,68 \\ \mathrm{Total} & 99,17 & 99,36 & 100,66 & 100,45\end{array}$

Nümero de cátions $(\times 1000)$ com base em 3 àtomos de oxigênio

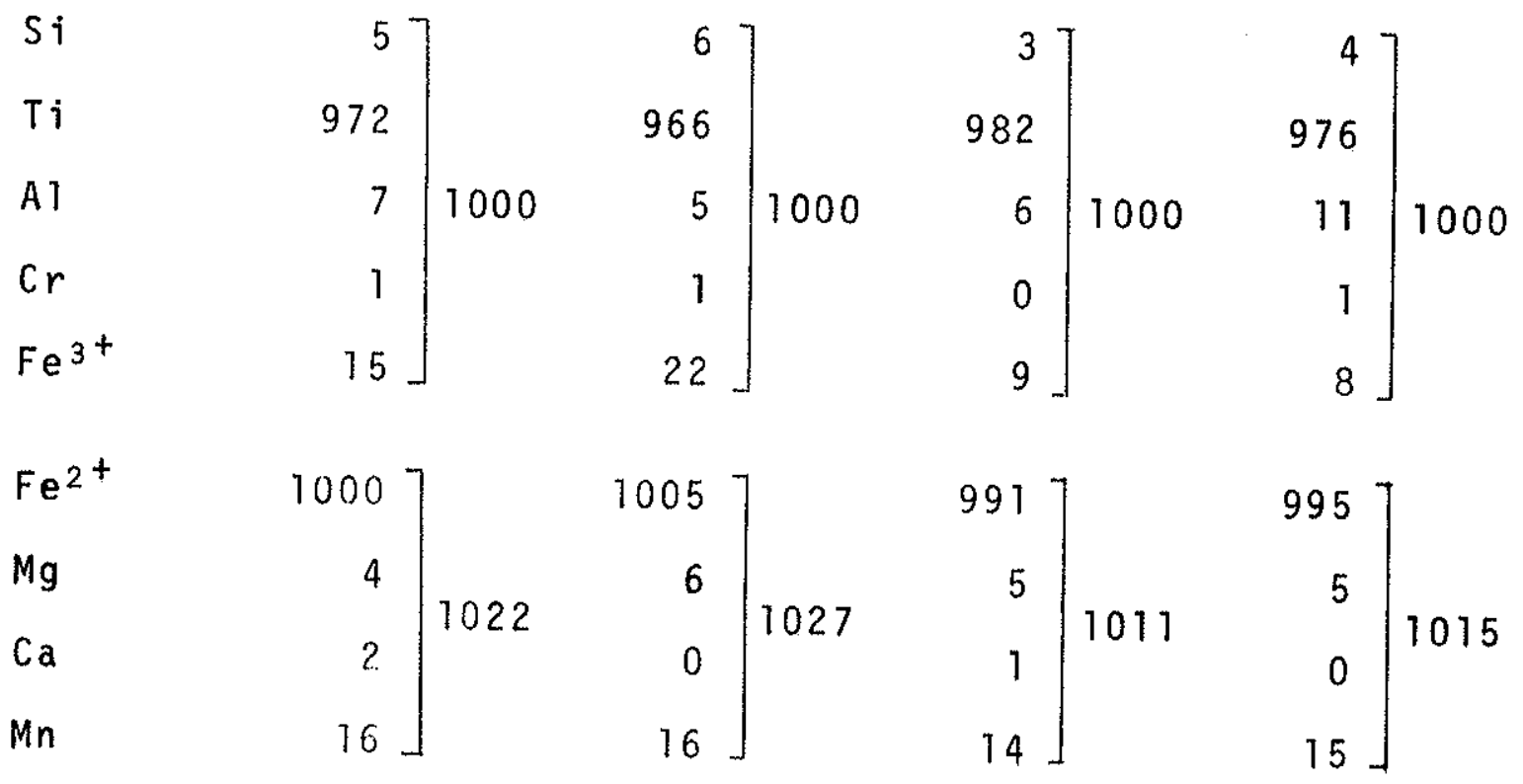


TABELA 15 - PORCENTAGENS DAS MOLËCULAS CONSTITUINTES DAS ILMENITAS INCLUSAS EM DIAMANTES BRASILEIROS

$\begin{array}{cccccr} & \begin{array}{c}\mathrm{MgTiO}_{3} \\ \text { Geikielita }\end{array} & \begin{array}{c}\mathrm{MnTiO}_{3} \\ \text { Pirofanita }\end{array} & \begin{array}{c}\mathrm{FeTiO}_{3} \\ \text { Ilmenita }\end{array} & \begin{array}{c}\mathrm{Fe}_{2} \mathrm{O}_{3} \\ \text { Hematita }\end{array} & \text { Total } \\ \text { MT-10b } & 0,40 & 1,51 & 96,30 & 0,80 & 99,01 \\ \text { BA-19a } & 0,40 & 1,60 & 95,91 & 1,12 & 99,13 \\ \text { G0-49a } & 0,42 & 1,40 & 98,11 & 0,50 & 100,43 \\ & 0,42 & 1,43 & 97,66 & 0,40 & 99,91\end{array}$


aparecem entre os elementos subordinados, todos em teores baixos $(<1,0 \%)$. Em termos de moléculas integrantes (Tabela 15), as referidas inclusões são constituidas essencialmente de ilmenita $\left(\mathrm{FeTiO}_{3}\right)$, com proporçóes reduzidas de pirofanita $\left(\mathrm{MnTiO}_{3}\right)$, hema tita $\left(\mathrm{Fe}_{2} \mathrm{O}_{3}\right)$ e geikielita $\left(\mathrm{MgTiO}_{3}\right)$.

As principais relações quĩmicas entre as inclusões as sociadas a diamantes brasileiros e ilmenitas de natureza kimber litica incluindo concentrados de kimberlitos e xenōlitos ultrama ficos estão representadas nas figuras 22 e 23 . 0 diagrama de vá riação ternāria da Figura 22, construído em termos das moléculas $\mathrm{FeTiO}_{3}$ (ilmenita), $\mathrm{MgTiO}_{3}$ (geikielita) e $\mathrm{Fe}_{2} \mathrm{O}_{3}$ (hematita), compa ra as inclusões estudadas com ilmenitas de kimberlitos diversos utilizando dados químicos de RINGWOOD e LOVERING (1970), DAWSON e REID (1970), BOYD e DAWSON (1972), GURNEY et al. (1973), MITCHELL (1973), BOYD E NIXON (1973a), FRICK (1973), SOBOLEV (1974), BOYD (1974a), BOYD E DANCHIN (1974), HAGGERTY (1975), MCCALLISTER et al. (1975), SMITH et al. (1976), SVISERO et al. (1977). o campo das ilmenitas kimberliticas estā perfeitamente definido, e ape sar da variação em $\mathrm{MgTiO}_{3}$ ser ampla, ela não contēm as inclú sões que se projetam muito prōximas do vērtice correspondente ao termo $\mathrm{FeTiO}_{3}$.

A Figura 23 compara a variação do nümero de ātomos de magnēsio e de ferro II das inclusões identificadas em diamantes brasileiros, com ilmenitas de kimberlitos, tendo sido utilizados dados de RINGWOOD e LOVERING (1970), BOYD e DAWSON (1972), BOYD e NIXON (1973a), MITCHELL (1973), GURNEY et al. (1973), SOBOLEV (1974), McCALLISTER et at. (1975). SMITH et al. (1976) e SVISERO et al. (1977). Confirma-se novamente a discrepāncia no tocante à quase ausencia de Mg nas inclusões analisadas. Esses dados pa recem indicar que as inclusões de ilmenita cristalizaram a par tir de um liquido pobre em magnësio. A julgar pelas demais in clusões, que de um modo geral são fases acentuadamente ricas em magnēsio, a ilmenita seria uma das ūitimas inclusões a se formar. E provāvel tambēm que a origem desta inclusão esteja relacionada 


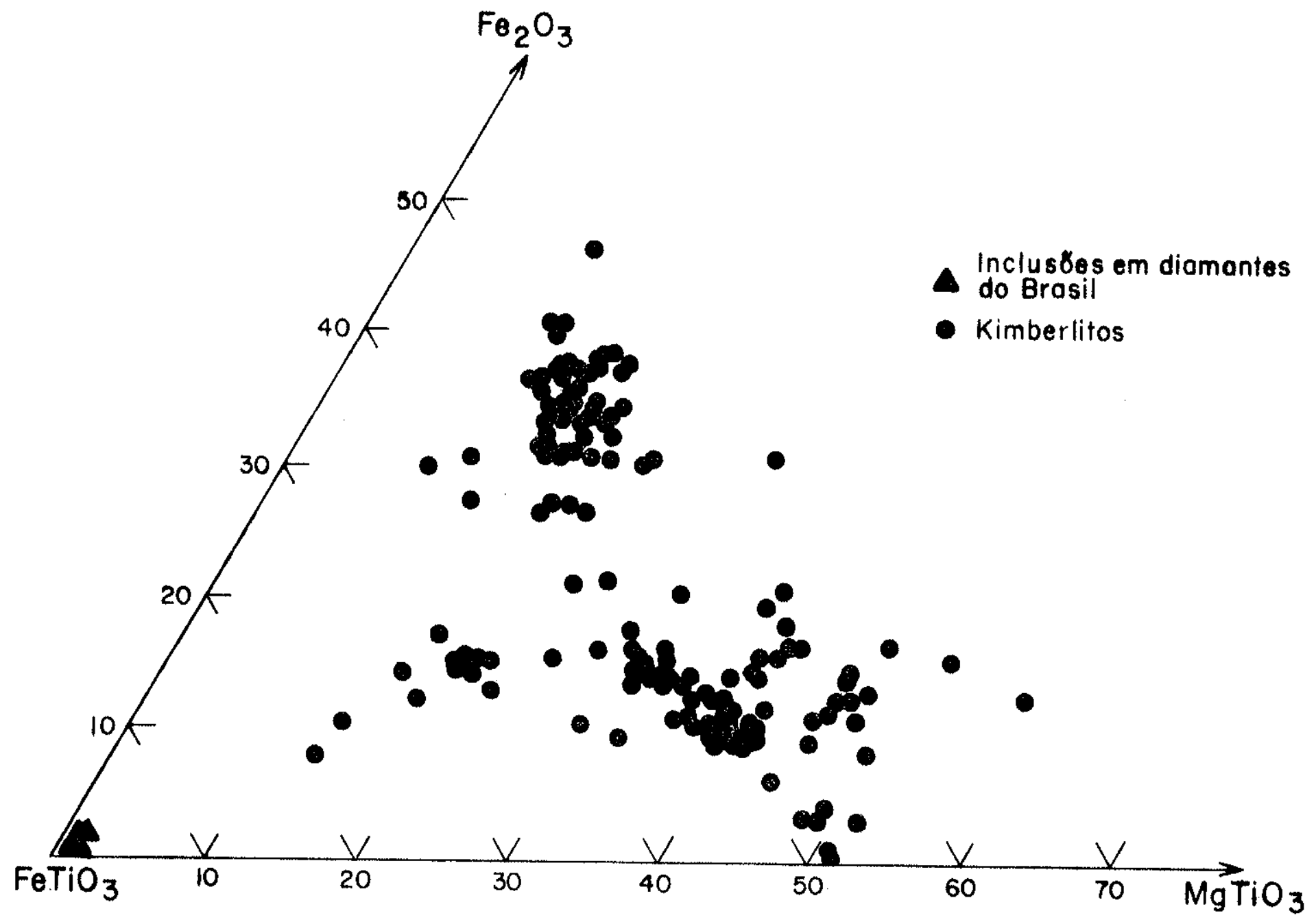

Figura 22 - Varıação da composição química de ilmenitas inclusas em diamantes do Brasil, comparadas com ilmenitas dekim berlitos em termos das moléculas de ilmenita (Ferio ${ }_{3}$ ), geikielita $\left(\mathrm{MgTiO}_{3}\right)$ e hematita $\left(\mathrm{Fe}_{2} \mathrm{O}_{3}\right.$ ). As ilmenitas de natureza ultramáfica exibem teores variávels das molé culas de ilmenita e geikielita; as inclusóes associadas a diamantes brasileiros, por suavez, são pobres em magnésio, e dessa forma, projetam-se próximo ao vér tices correspondente à molécula de FeTio 3 . Dados compá rativos extraidos de RINGWODD e LOVERING (1970); DAWSON E REID.(1970); BOYD e DAWSON(1972); GURNEY etaZ(1973); MITCHELL (1973); BOYD E NIXON (1973a); FRICK (1973); SOBOLEV (1974); BOYD (1974a); BOYD E DANCHIN (1974); HAGGERTY (1975); MCCALLISTER et al (1975); SMITH et al (1976); SVISERO et al (1977). 


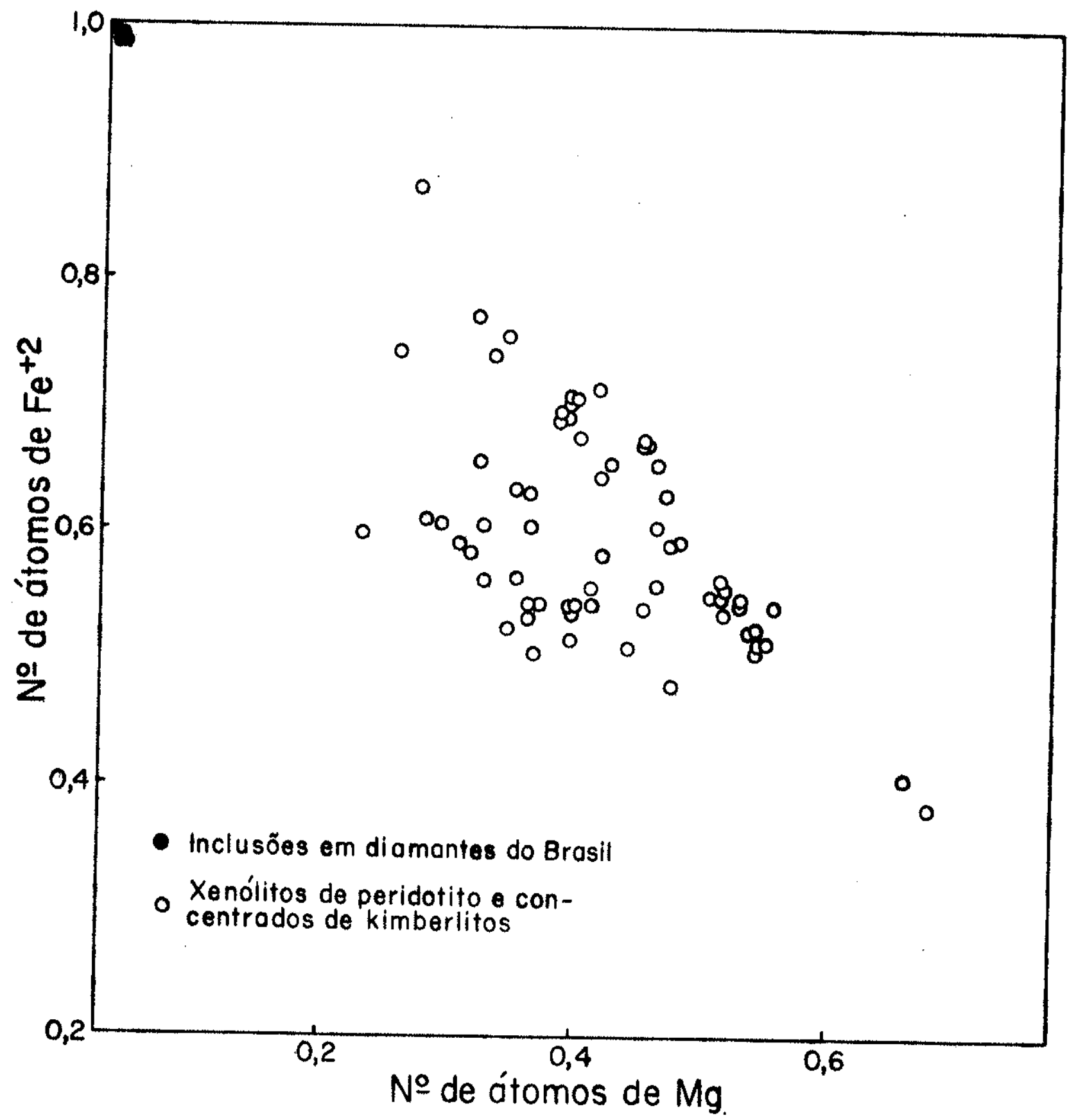

Figura 23 - Variação do nümero de átomos de magnésio e de ferro I de ilmenitas inclusas em diamantes do Brasil comparados com ilmenitas de natureza kimberlitica. As 1 imenitas associadas a diamantes brasileiros são pobres de magnésio e projetam-se fora do campo das ilmenitas de natureza ultramáfica. Dados comparativos extraidos de RINGWDOD E LOVERING (1970); BOYD E DAWSON (1972); BOYD \& NIXON (1973a); MITCHELL (1973); GURNEY et al (1973); SOBOLEV (1974), MCCALLISTER et al(1975); SMITH et al (1976); SVISERO et $a Z(1977)$. 
a diamantes de natureza eclogitica. De qualquer modo, esse pro blema sō poderā ser devidamente esclarecido quando houver um nū mero maior de anälises disponīveis na literatura. E provāve que se obtenha então, uma interpretação satisfatöria do papel representado pelo titānio na gēnese do diamante. Uma das opi niões vigentes $\bar{e}$ de que esse elemento inibe a cristalização do diamante (MILASHEV, 1965). Contudo a presença de ilmenita em alguns diamantes constitui um sērio obstāculo à hipōtese de MILASHEV; mas por outro lado, essa observação traz em si a dificuldade relacionada a ausēncia de magnēsio. Como se vë, o pro blema è complexo e sō poderā ser esclarecido à medida que novos dados forem sendo registrados.

\section{PIRROTITA}

SHARP (1966) mostrou pela primeira vez que os sulfetos são inclusões comuns, identificando pirrotita ( $\mathrm{Fe}_{1-\mathrm{x}} \mathrm{S}$ ), pentian dita $\left|(\mathrm{Fe}, \mathrm{Ni})_{9} \mathrm{~S}_{8}\right|$ e pirita $\left(\mathrm{FeS}_{2}\right)$ em diamantes da Africa do Sul. HARRIS (1968) confirmou as observações de SHARP e, poste riormente, notou uma certa tendēncia dos sulfetos se alojarem ao longo de pequenas clivagens circundando outras inclusões (HARRIS, 1972). Em trabalho recente GIARDINI e MELTON (1975) comprovaram a disposição preferencial dos sulfetos ao longo de planos (111) do diamante.

Esses resultados se aplicam aos diamantes brasileiros, apenas com a ressalva que todos os sulfetos identificados corres pondem ao mineral pirrotita. A cor, aparentemente negra, $\overrightarrow{\mathrm{e}} \underline{\mathrm{a}}$ da por uma pelĩcula finissima que reveste toda a superfície da inclusão. A confecção das secções polidas para a microssonda ele trōnica revelou que internamente, a cor $\bar{e}$ amarela do latão e ó brilho metälico intenso. 0 häbito ē geralmente tabular mas a forma dos cristais é extremamente variada e irregular (Microgra 


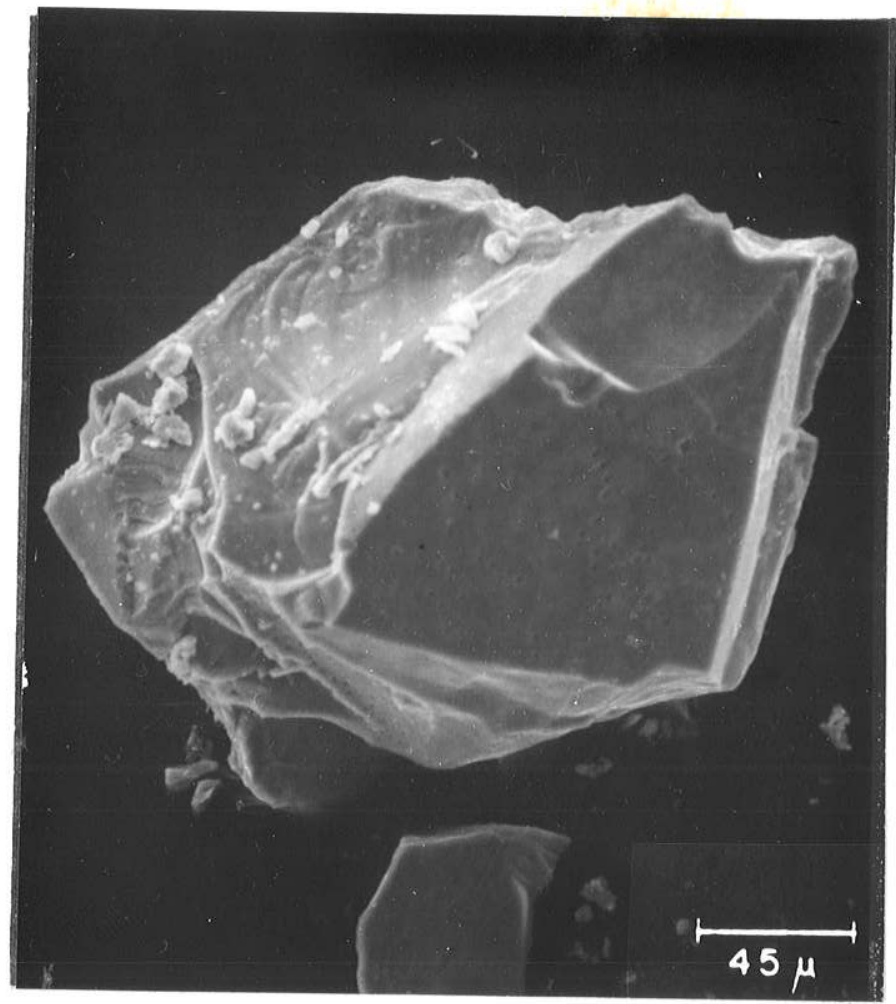
$\begin{aligned} \text { Micrografia eletrônica } 18 \text { - Inclusão de pirrotita parcialmente } & \\ & \text { fraturada }\end{aligned}$

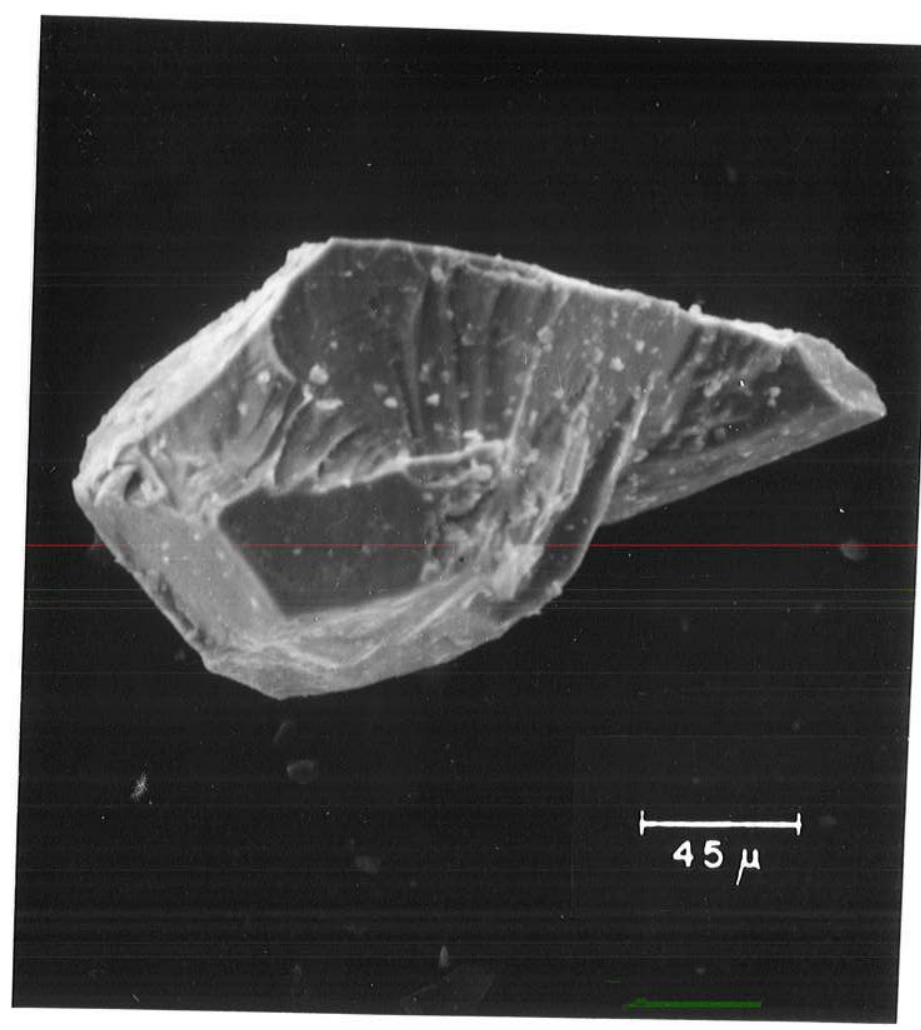

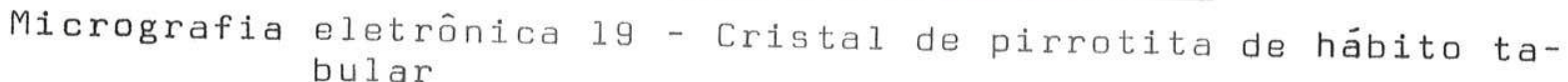


TABELA 16 - COMPOSIÇAO QUIMICA DE INCLUSOES DE PIRROTITA EM DIAMANTES DO BRASIL

$\begin{array}{lcccc} & M T-36 a & M T-36 b & M G-41 a & P R-28 a \\ \mathrm{~S} & 37,78 & 38,24 & 37,59 & 37,88 \\ \mathrm{Fe} & 62,36 & 61,20 & 62,50 & 62,22 \\ \mathrm{Ni} & 0,48 & 1,26 & - & - \\ \mathrm{Cr} & 0,02 & 0,03 & - & - \\ \mathrm{Cu} & - & - & 0,06 & - \\ \text { Total } & 100,64 & 100,73 & 100,15 & 100,09 \\ & & & & \\ \mathrm{~S}: \mathrm{Fe} & 0,94 & 0,92 & 0,95 & 0,94\end{array}$


fia eletrōnica 18). O indivíduo da Micrografia 19 jā é bem regu lar sendo formado por uma bipirâmide hexagonal achatada. A sime tria hexagonal è evidente, apesar do desproporcionamento acentua do do cristal.

A composição química ē constante no que diz respeito aos elementos essenciais ferro e enxofre. A razão $S$ : Fe varia entre 0,92 a 0,95 (Tabela 16). Entretanto, hä diferenças marcan tes em relação aos elementos subordinados. As duas pirrotitas de diamantes de Mato Grosso contēm $\mathrm{Cr}$ e proporções substanciais de $\mathrm{Ni}$; a de Minas Gerais apenas pequenos teores de $\mathrm{Cu}$, enquanto que o espēcime do Paranā é totalmente isento de impurezas.

os sulfetos constituem um grupo de inclusões pouco co nhecidas (GUBELIN, 1977). Em parte, isso è devido à facilidade que eles apresentam de se reequilibrar com a temperatura, de tal forma que as fases identificadas podem não corresponder ao mate rial formado originalmente. Segundo TSAI et al. (1977), no caso do diamante, o sulfeto original era provavelmente uma solução sō lida de vārios metais. Com o decréscimo da temperatura, houve segregação das fases ricas em Cu (calcopirita), deixando um resí duo rico em niquel e ferro que posteriormente se reequilibrou for mando pentlandita e pirrotita. O problema, como se observa, $\bar{e}$ realmente complexo e está sendo estudado por $H$. TSAI em sua tese de doutoramento junto a Purdue University, Estados Unidos da Ame rica (TSAI: comunicação pessoal em outubro de 1977).

DIAMANTE

Confirmando observações de diversos autores (WILLIANS, 1932, GUBELIN, 1952, 1969; FUTERGENDLER, 1958, GNEVUSHEV et al., 1961), verificamos que inclusões de diamante no prōprio diamante constituem um evento comum. As Fotomicrografias 5 e 6 , mostram duas dessas inclusões identificadas em diamante de Mato Grosso e 


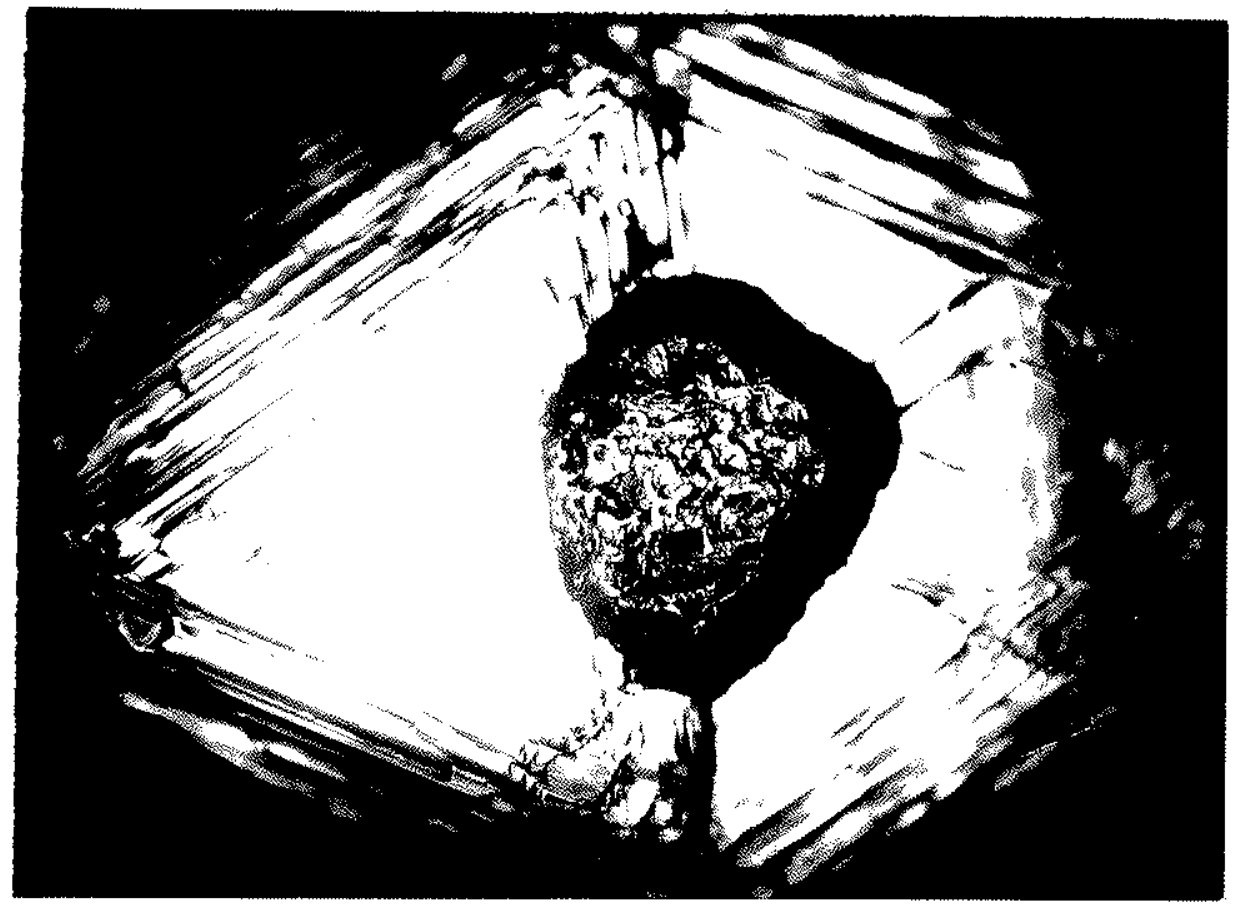

Fotomicrografia 5 - Cristal de diamante de hábito tabular (chapéu de fradel, contendo no centro uma inclusão de diamante de cor cinza e superfície rugosa.Nesse caso, a distinção entre ambos é facilitada pelas diferenças físicas entre a inclusão e o hospedeiro.Nícois paralelos.20x

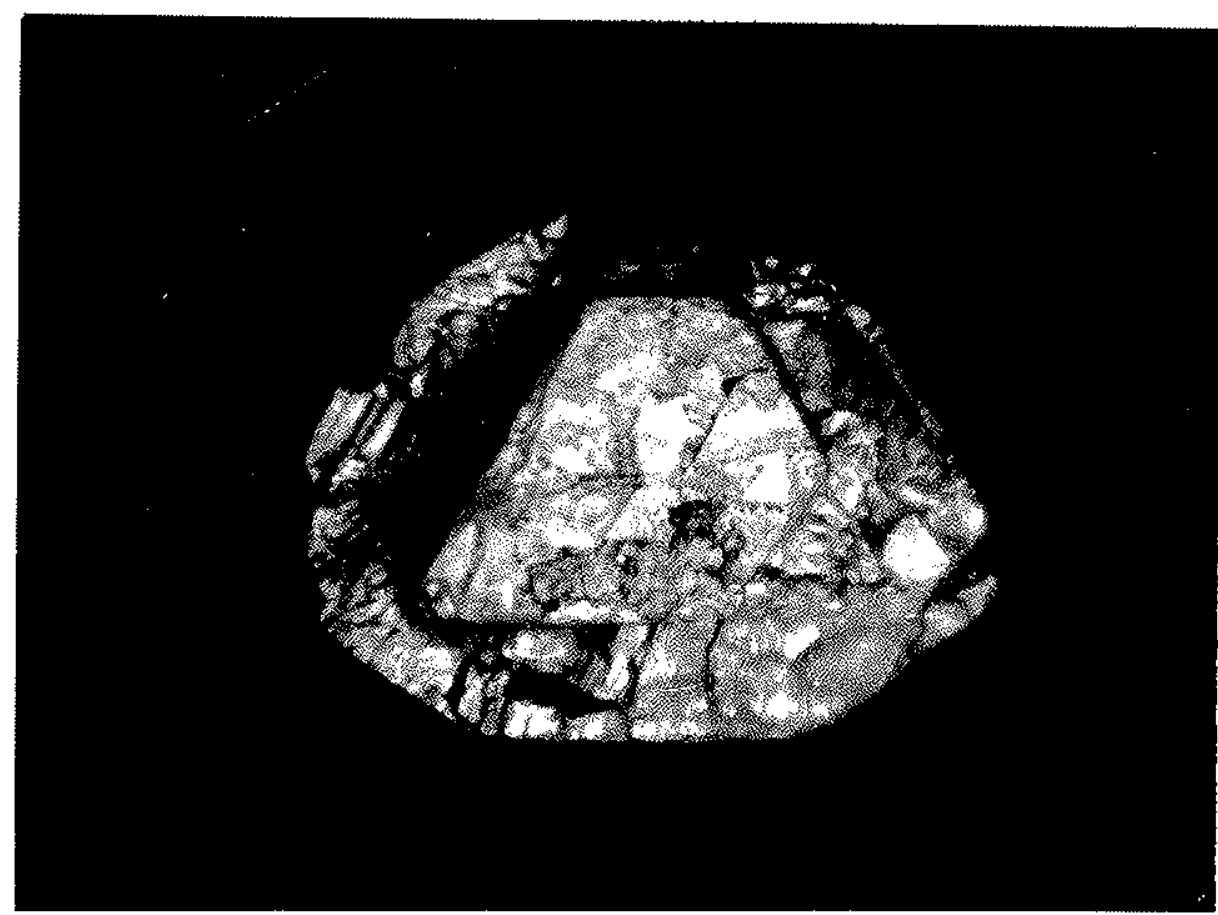

Fotomicrografia 6 - Diamante incolor incluso em hospedeiro tambëm incolor. A inclusão exibe hábito octaédri co e faces planas, enquanto que o hospedeiro apresenta hábito rombododecaédrico e faces abauladas. Nícois paralelos, $20 x$. 
São Paulo, respectivamente.

Usualmente, o diamante incluso exibe hābito octaēdrico perfeito, faces planas e arestas perfeitamente retilineas, con trastando com a morfologia do hospedeiro caracterizada pelo abau lamento das faces e arestas. A nosso ver, essa è uma das mais fortes evidências em favor da hipōtese jā comentada de que o dia mante passa por uma fase de dissolução que imprime feições carac terísticas e definitivas em sua morfologia externa (SVISERO, 1971; WHITELOCK, 1973). Outra conclusão 10̄gica ē que a fase mais in tensa de dissoluçăo ocorre apōs a cristalização do diamante, pro vavelmente durante a intrusão do kimberlito pois de outra forma, as inclusöes de diamante seriam afetadas pela dissolução.

A distinção entre o diamante incluso e o hospedeiro é extremamente difícil, a näo ser que ambos passuam colorações di ferentes. Outro fato que auxilia a reconhecimento é a presença de manchas escuras (clivagens ou sulfetos) circundando o indivi duo incluso. Na falta dessas feições, a ūnica forma de identifi car a inclusäo é utilizar difração de raios $x$.

As Fotomicrografias 5 e 6 mostram dois casos distintos de associação diamante-diamante. No primeiro (Fotomicrografia 5), a inclusäo pode ser notada a olho nü, pois exibe cor e aspectos morfolögicos completamente distintos do diamante hospedeiro. 0 mesmo näo ocorre no segundo caso (Fotomicragrafia 6), onde a inclusăo, possuindo cor idêntica a do hospedeiro, confunde-se com ele tornando difícil o seu reconhecimento.

\section{TNCLUSÖES EPIGENÉTICAS}

Sob esse tîtulo estäo reunidos todos os minerais forma dos posteriormente ao diamante, e a ele associados por fenōmenos diversos subsequentes. As inclusões epigenēticas, tambēm denomi nadas secundārias, constituem um grupo de minerais relativamente amplo e heterogēneo formado pela serpentina, goethita, grafita, 
hematita, sellaita, caolinita, anfibölio, sanidina e xemotima (HARRIS, 1968; MEYER e TSAI, 1976). No decorrer deste trabalho acrescentamos à essa lista as seguintes espēcies: limonita, tur malina, magnetita, quartzo e mica (Tabela 2).

Alguns minerais epigenéticos se originam pela altera ção de fases preexistentes; outros correspondem a substāncias estranhas acidentalmente incorporadas pelo diamante durante os sucessivos episōdios que vão desde sua cristalização atē sua incorporação por sedimentos. Em função dessas caracterīsticas, as inclusões epigenēticas são totalmente desprovidas de qual quer interesse geolögico no que diz respeito à origem do diaman te.

A introdução de substāncias estranhas ao longo de fra turas e cavidades do diamante se inicia antes mesmo dele deixar o kimberlito. ORLOV (1959) observou que uma grande quantidade de diamantes dos kimberlitos siberianos continham serpentina dis tribuida ao longo de fraturas e outras irregularidades. A in corporação de materiais estranhos prossegue durante os sucess vos ciclos de transporte e sedimentação que envolvem o diamante e explicam a presença de minerais como a turmalina, a monazita e outros não relacionados aos kimberlitos.

outros minerais epigenēticos formam-se pela alteração de fases preexistentes. Inclusões de olivina e piroxēnio alte ram-se com relativa facilidade, no caso do diamante conter fra turas, transformando-se em limonita, serpentina e outros produ tos secundārios. 0 prōprio diamante transforma-se lentamente em grafita que "sensu latu" constitui a mais tïpica inclusão epi genētica. HARRIS (1972) observou que as inclusões de grafita normalmente são tabulares ou placōides e devem essa forma ao fa to de constituirem lejtos delgados ao longo de planos de cliva gens do diamante. Posteriormente, HARRIS e VANCE (1972) graf tizaram diversos diamantes, e notaram que a grafita então forma da se dispunha exatamente como nos cristais naturais, is to é,ao longo de planos de clivagens. Essa experiēncia comprova que a 


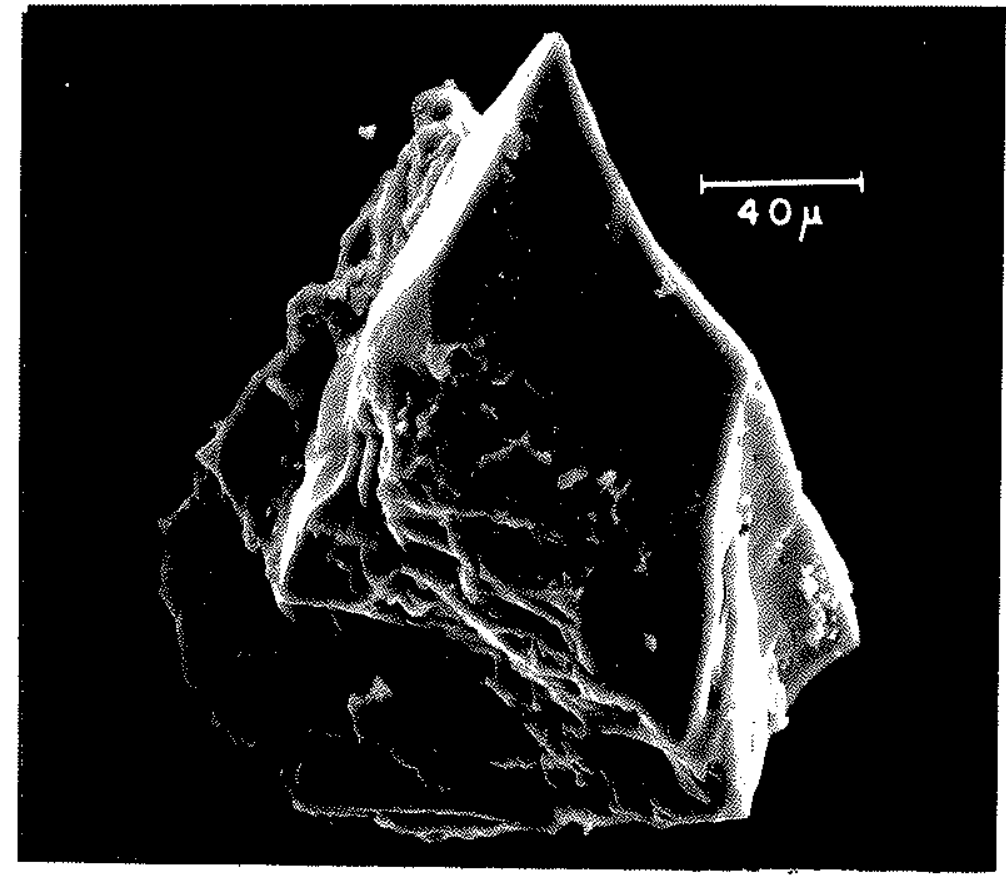

Micrografia eletrônica 20 - Fragmento de quartzo alojado nos interstícios do microrelevo de um cristal de diamante. Notar a extrema irregularidade do grão contrastando com o idiomorfismo das inclusões singenéticas. Aumen to $400 \times$. 
presença de grafita no diamante constitui uma tentativa do hospe deiro de reequilibrar-se às novas condições de temperatura e pressão fora do kimberlito.

Nenhum mineràl epigenētico causou tanta discussão como o quartzo. Sua presença em fraturas e cavidades (Micrografia ele trōnica 20) è perfeitamente compreensīvel considerando sua abun dāncia e distribuição ampla em quase todos os tipos de rochas da crosta terrestre. E provāvel que as determinações de PETZHOLDT (1842), COLONY (1923) e CORRENS (1931), se referissem a esse ti po de material.

Entretanto, o que tem suscitado polēmica é que em al guns casos o quartzo ocorre dentro de diamantes absolutamente isentos de fraturas (ORLOV, 1959; HARRIS, 1968; MEYER e SVISERO, 1973; PRINZ et al., 1975). Nesses casos, o problema torna-se com plexo, pois é fato bem conhecido que o campo de estabilidade do quartzo è totalmente incompatīvel com as condições de formação do diamante, tanto na natureza quanto em laboratōrio (Figura 26). Portanto, se algum diamante por ventura contiver sîlica, ela de ve estar sob a forma de coesita, que é o polimorfo estāvel de al. tas pressões. Esses conceitos estão bem estabelecidos experimen talmente (BERMAM, 1965; AKIMOTO e SYONO, 1971) e foram confirma dos por MILLEDGE (1961) e HARRIS (1968) ao identificarem coesita em diamantes, artificiais e naturais, respectivamente. Parece não haver dūvida, portanto, sobre a impossibilidade do quartzo constituir uma inclusão singenētica no diamante. Nessas condi ções, a presença de quartzo em diamantes isentos de fraturas sō pode ser explicada admitindo-se que a inclusão original fosse coesita, que posteriormente se reequilibrou às novas condições de temperatura e pressão, adquirindo a estrutura cristalina do quartzo (LIVSHITS et al., 1973). 


\section{OUTRAS INCLUSÕES}

Cianita e flogopita (PRINZ et al.,1975) e biotita (GIARDINI et al., 1974) são outras inclusões singenéticas provāa veis do diamante (Tabela 17). A cianita exibe hābito prismáti co e cor azul clara; entretanto, o que chama a atenção ē seu baixo teor de $\mathrm{Cr}_{2} \mathrm{O}_{3}$ (Tabela 17), contrastando com cianitas cro míferas de kimberlitos siberianos (SOBOLEV et al., 1968). Flogo pita é um dos constituintes principais de kimberlitos (DAWSON, 1967), mas o registro de PRINZ et al. (1975) é o único da lite ratura. Com relação à biotita (WILLIANS, 1932; GIARDINI et al., 1974), sua natureza singenética é vista com certa reserva por um grande número de pesquisadores (MEYER: comunicação pessoal em outubro de 1977).

Acreditamos ser oportuna, agora, uma breve discussão das inclusões negras (carvões) tão comuns em diamantes naturais. HARRIS (1972) e GIARDINI e MELTON (1975) mostraram que, em par te, elas correspondem à grafita e a sulfetos que se dispõem sob a forma de placas ou camadas muito finas ao longo de planos de clivagem do diamante. Há casos, entretanto, em que as manchas escuras nada mais são do que meros fenômenos ópticos produzidos no interior do diamante (SVISERO, 1971a). Nesse caso, a inten sidade da cor varia à medida que se gira o cristal, e para uma dada posição, ela pode desaparecer completamente. Sua origem es tá relacionada a microfraturas do diamante que funcionam como pequenas lentes biconvexas, em cujo interior, evidentemente, re $i$ na vācuo. A luz que passa pelo diamante, ao penetrar no espaço correspondente a essas fraturas sofre reflexão total, e a re gião torna-se enegrecida dando a impressão de existir alguma substância escura naquele local. Isso explica o carāter irregu lar e a orientação invariável dessas manchas segundo o plano (111) do diamante, que è exatamente a direção mais favorável à descontinuidade mecânica. 
TABELA 17 - COMPOSIÇAO QUIMICA DE INCLUSÖES dE NATUREZA INCERTA

oxidos

$\mathrm{SiO}_{2}$

$\mathrm{TiO}_{2}$

$\mathrm{Al}_{2}{ }^{\mathrm{O}} 3$

$\mathrm{Cr}_{2} \mathrm{O}_{3}$

$\mathrm{Fe}_{2}{ }^{\mathrm{O}} 3$

$\mathrm{Fe} 0$

Mg0

$\mathrm{CaO}$

$\mathrm{MnO}$

$\mathrm{Na}_{2} \mathrm{O}$

$\mathrm{K}_{2} \mathrm{O}$

Tota 1
Cianita $\left({ }^{1}\right)$

36,6

0,13

62,1

0,02

$-$

0,30

$$
0,04
$$

0,01

$<0,01$

0,03

0,10

9,6

94,7

0,35

12,1

12,6

0,09

0,04

99,2
Biotita $\left({ }^{3}\right)$

34,0

3,63

16,7

0,63

7,63

9,33

92,9

1 e 2:Africa, local desconhecido (PRINZ et al. 1975)

3:I dem (GIARDINI et al.1974) 
Finalmente, resta-nos considerar as inclusões fluidas, referidas desde o século passado (BREWSTER, 1835; JANNETTAZ, 1879; GUBELIN, 1952), e cuja existência continua sendo objeto de dis cussões. MELTON et al, (1972) e MELTON e GIARDINI (1974, 1975), determinaram diversos compostos gasosos contendo carbono, hidrogênio, nitrogēnio e oxigênio, provenientes de diamantes fragmen tados no vācuo. Como jā referimos em outros capitulos, infeliz mente os referidos autores não levaram em conta as inclusões cris talinas que, eventualmente, poderiam ser a fonte dos gases detec tados (Vide Micrografias eletrōnicas 1, 2, 4, 10 e 12).

FESQ et al. (1975), apōs analisarem 1500 diamantes dos kimberlitos Premier, Finsch e Jagersfontein, por ativação de nēu trons, concluiram pela existência de diversos tipos de inclusões fluidas. Segundo esses autores, a maior parte dos diamantes con têm micro-inclusões de $\mathrm{H}_{2} \mathrm{O}$ e $\mathrm{CO}_{2}$ ao lado de sulfetos de $\mathrm{Fe}, \mathrm{Ni}$, $\mathrm{Cu}$, e $\mathrm{Co}$, que eles acreditam representar os componentes misci veis e imisciveis do magma original onde o diamante se cristalizou.

\section{INCLUSOEES COEXISTENTES}

Jä foi mencionado que um mesmo diamante pode conter, simultaneamente, mais de uma espëcie mineral constituindo asso ciações de dois ou mais componentes (MEYER e SVISERO, 1975;PRINZ et al., 1975). Essas associações são importantes do ponto de vista genético. Admitindo-se que o diamante cristaliza em equiİ́brio no seio de um magma peridoditico, as inclusões por ele aprisionadas são representativas das condições reinantes no mo mento da sua cristalização.

Baseados nessa hipótese, MEYER e BOYD (1972) tentaram determinar a temperatura de formação do diamante a partir do par olivina + crōmioespinētio, utilizando os termōmetros geológicos 
de IRVINE (1965 e 1967) e JACKSON (1969). As temperaturas obti das, da ordem de $4000^{\circ} \mathrm{C}$, foram consideradas inverossimeis, sendo o par abandonado por insuficiēncia de dados termoquimicos. identificação de vārias associações contendo diopsídio em diaman tes do kimberlito Premier, Africa do Sul, permitiu a MEYER e TSÄI (1976a) fazer uso do termómetro geológico de BorD (1973). A par tir das associações diopsidio + enstatita + crōmiopiropo, diop sidio + enstatita, e, diopsidio + enstatita + piropo; eles obti veram temperaturas e pressões da ordem de $1100^{\circ} \mathrm{C}$ e 50 kbars, re $\underline{s}$ pectivamente, consistentes com outros parämetros referentes a má teriais da crosta e do manto superior (Figura 26).

As associações identificadas nos diamantes brasileiros são constituĩdas pelos pares olivina + enstatita, olivina + crō miopiropo,olivina + crômioespinēlio, e enstatita + crōmiopiropo (Tabelas $3,5,8$ e 10 ). Suas relações químicas principais estão ilustradas no diagrama ternārio $\mathrm{R}_{2} \mathrm{O}_{3}-\mathrm{Mg} 0-\mathrm{Fe} 0$ da Figura 24 . Alēm do carāter biminerálico, elas se caracterizam pela frequéncia da olivina que aparece na maior parte das associações. Do ponto de vista químico, todas as fases integrantes das quatro associações são ricas em magnësio e pobres em ferro II. Os diagramas ternā rios da Figura 24 mostram, nitidamente, que a variação mais signi

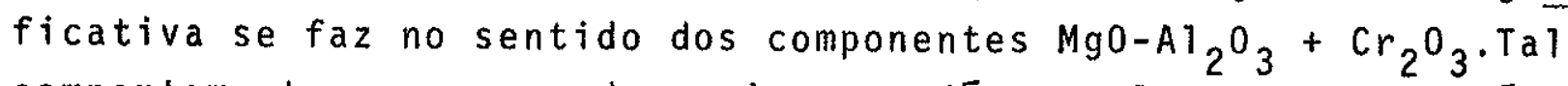
comportamento era esperado, pois como jā ressaltamos nos capitu los anteriores, diversas inclusões, especialmente as crômiopiró pos e os crômioespinēlios, possuem teores considerāveis de crō mio.

0 par olivina-enstatita presta-se a estudos de parti ção entre os elementos químicos magnēsio e ferro II (SVISERo e VALARELLI, 1977). Essa possibilidade se deve a MEDARIS (1969), que estabeleceu uma curva experimental de partição entre esses dois elementos, utilizando olivinas e enstatitas de composiçoes. variadas, cobrindo todo o intervalo entre 0 a $100 \%$ de cada um dos componentes.

Na Figura 25 estão projetados diversos valores referen 

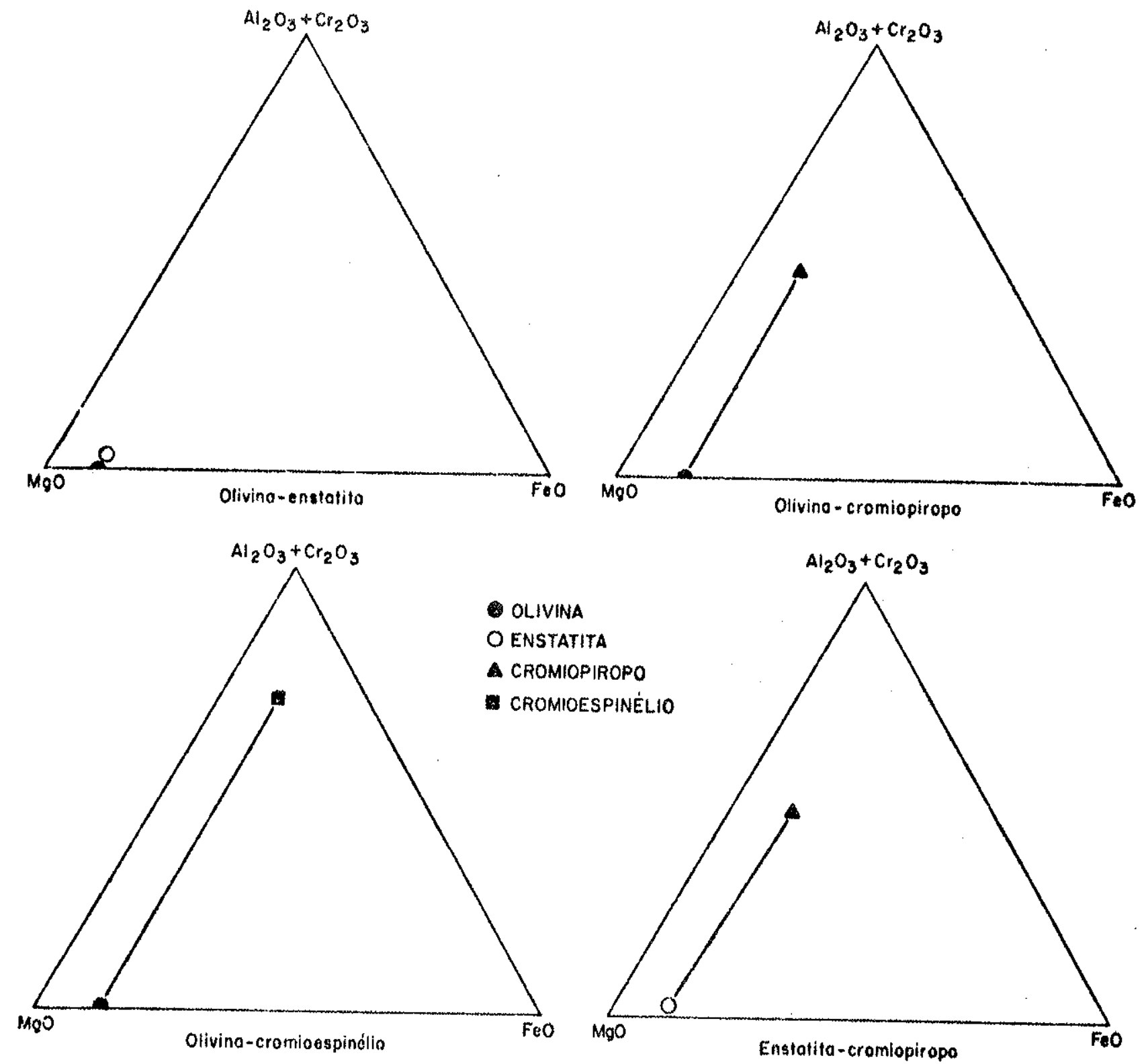

Figura 24 - Variação dos elementos quimicos principals de associações biminerálicas coexistentes em diamantes do Brasil. Observa se que todas as associaçóes contémpe Lo menos uma fase rica em Mgo e que a varlaça ma significativa se opera no sentido dos componentes Mga $-\mathrm{Al}_{2} \mathrm{O}_{3}+\mathrm{Cr}_{2} \mathrm{O}_{3}$. O teor de $\mathrm{FeO}$ é uniformemente baixo em todas as associações. 


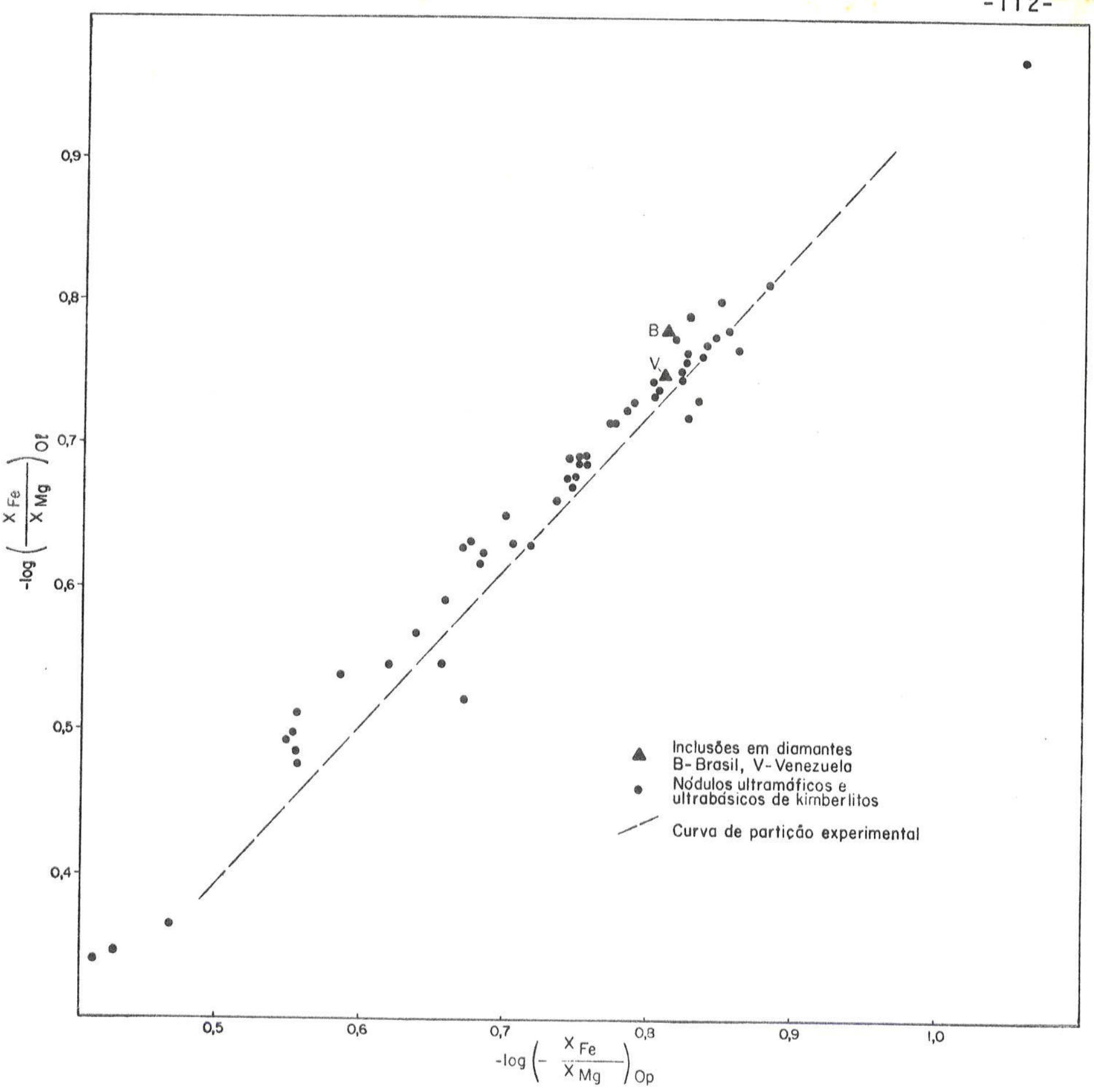

Figura 25 - Partição $\mathrm{Mg} / \mathrm{Fe}^{2}{ }^{+}$entre olivinas e enstatitas constituintes de associações ultramäficas kimberlíticas.0s triângulos representam in clusões de olivina e enstatita coexistentes em diamantes do Brasil e da Venezuela; os círculos representam olivinas e enstatitas constituintes de xenólitos ultramáficos de kimberlitos. As inclusões situam-se próximo à curva de partição determinada experimentalmente indicando que a sua cristalização se operou sob condições de equilíbrio. Além disso,elas projetam-se na extremidade superior da referida curva juntamente com os xenólitos formados nos estágios iniciais da cristalização do magma peridotítico.A linha tracejada é a curva de partição estabelecida experimentalmente por MEDARIS (1969). Dados comparativos referentes aos xenólitos foram extraídos de BLOOMER e NIXON(1973), COX et al. (1973), NIXON e BOYD (1973), ROLFE(1973), BOYD(1974a), HEARN e BOYD(1975),BOYD e NIXON (1975). 
tes à partição entre magnēsio e ferro II relativos a pares ol vina-enstatita de natureza kimberlítica. Os dois triângulos re presentam associações coexistentes em diamantes do Brasil (B) e Venezuela (V); os cīrculos cheios referem-se a associações cons tituintes de xenōlitos ultramāficos de kimberlitos (BLOOMER e NIXON, 1973; COX et al., 1973; NIXON e BOYD, 1973; ROLFE, 1973; BOYD, 1974a; HEARN e BOYD, 1975; BOYD e NIXON, 1975).

Observa-se que os pontos correspondentes às diversas associações projetam-se satisfatoriamente ao longo da curva es tabelecida por MEDARIS (1969). Esse fato indica que os pares olivina-enstatita referentes às inclusões em diamante e aos xe nōlitos ultramäficos, cristalizaram em condições de equilībrio. os pares correspondentes às inclusões de diamante situam-se prō ximos da extremidade superior da curva de partição,evidenciando que a cristalização, nesse caso operou-se em um estāgio bem in cial em relação à maior parte dos xenōlitos utilizados na compa ração. Outra observação importante diz respeito às relações en tre temperatura e pressão durante a cristalização. Os dois pá res associados a diamantes, e a maior parte daqueles referentes a xenōlitos de kimberlitos caem do lado esquerdo da curva de MEDARIS que, segundo o referido autor, è a região onde a ação de pressão è maior do que aquela correspondente à temperatura. Esse resultado concorda perfeitamente com algumas conclusões ba seadas na composição quîmica das inclusões, discutidas em cap $\underline{\bar{i}}$ tulos anteriores, que colocaram em destaque a ação de pressões intensas na gênese do diamante e de suas inclusões. 


\section{SIGNIFICADO GEOLOGICO DAS INCLUSOES}

Apōs examinarmos cada um dos minerais identificados em diamantes de diversas localidades do Brasil,discutiremos nes te capitulo algumas das implicações decorrentes desta investiga ção. A primeira delas diz respeito à formação do diamante na natureza. Como foi visto nos capĩtulos anteriores a composição quỉmica das inclusões é um reflexo das condições físicas e quí micas existentes no momento da formação desses minerais. Tais condições, em princīpio, são as mesmas existentes durante a for mação do diamante. 0 fato delas terem sido englobadas e mánti das isoladas dos eventos kimberliticos subsequentes credencia seu uso como termômetros e barōmetros geológicos. A partir da composição das inclusões, pode-se especular ainda a natureza da rocha matriz em cujo seio a cristalização do diamente se operou.

Outro aspecto importante nesta pesquisa é a origem das inclusões. Trata-se, evidentemente, de um tema abrangente e complexo que tem implicações diversas com a própria origem dos kimberlitos e dos seus xenōlitos ultramāficos e ultrabásicos, e em ūitima instância, com a composição do manto superior que é o local de proveniência de todos esses materiais.

\section{GÊNESE DO DIAMANTE}

A gênese do diamante foi sempre um problema controver tido. Logo apōs a localização da sua rocha matriz na Ärica do Sul no final do sēculo passado, houve um impulso extraordinārio nas pesquisas referentes à origem do diamante, o que motivou o aparecimento das obras clássicas de WAGNER (1914), SUTTON (1928) e WILLIANS (1932). Após a publicação do tratado de Willians houve uma diminuição sensĩvel dessas pesquisas que sō seriam 
reativadas vinte anos depois com a descoberta dos kimberlitos da Plataforma Siberiana. Nas duas ültimas dëcadas as observações geolōgicas se multiplicaram dado o interesse econōmico cada vez maior em relação ao diamante. Paralelamente, a investigação ex perimental progrediu muito possibilitando uma compreensão me Thor dos fenômenos envolvidos na gênese do diamante.

CONDIÇOES FISICAS DE FORMAÇÃO DO DIAMANTE

Apesar de ainda persistirem diversas düvidas sobre a sequência exata dos processos que conduzem à formação do dia mante na natureza, hā um consenso unānime entre os pesquisado res de que esse mineral se forma no manto superior. 0 gräfico da Figura 26, construỉdo pela superposição de diversos parâme tros teöricos e experimentais estabelecidos nos ūitimos anos, a 1 ëm de comprovar a veracidade dessa afirmação, permitiu-nos de limitar de forma aproximada, a região mais provāvel de formação do diamante na natureza.

Resumidamente, o referido diagrama reune os seguintes elementos: 1) a curva de equilïbrio diamante-grafita estabeleci da experimentalmente por BERMAN (1965); 2) uma parte do diagra ma de equilibrio da silica (AKIMOTO e SYONO, 1971), ressaltando - campo de estabilidade dos polimorfos cuja relação com o dia mante tem sido objeto de discussão. E fācil ver que o campo de estabilidade do quartzo ë incompatível com as condições de for mação do diamante. Conclui-se que pelo menos teoricamente, o quartzo não pode coexistir com o diamante. 0 polimorfo $\mathrm{SiO}_{2}$ compatĩvel com o diamante $\vec{e}$ a coesita, o que comprova os resul tados de MILLEDGE (1961) e HARRIS (1968); 3) as curvas referen tes aos campos de estabilidade de peridotitos (ITO e KENNEDY, 1967) e eclogitos (ITO e KENNEDY, 1970). Ambas são compatĩveis com o campo de estabilidade do diamante; 4) duas curvas corres 


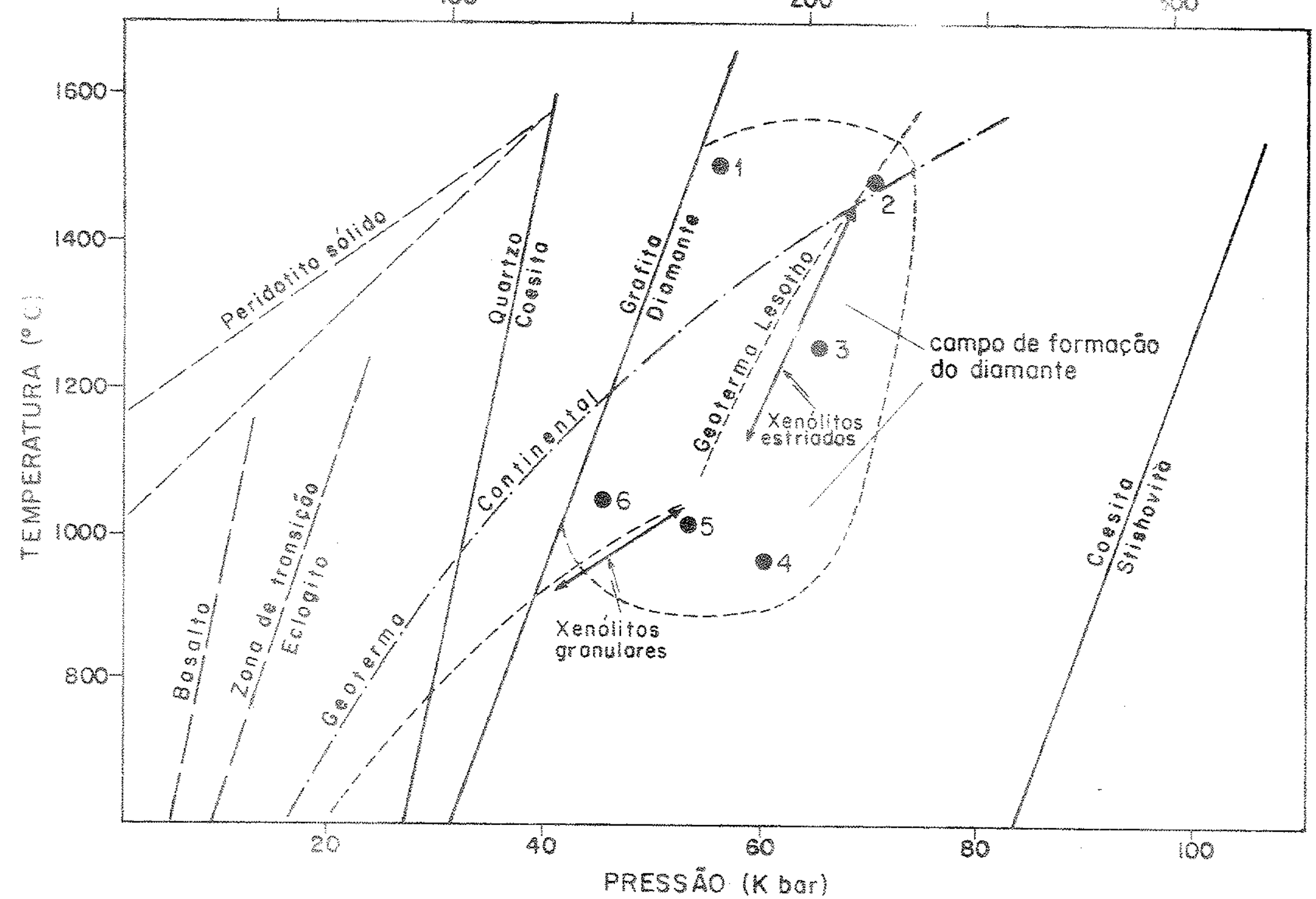

Figura 26 - Campo de fomacão do diamente ne natureze delimitado a partir dos seguintes parâmetros: geoterma conti-

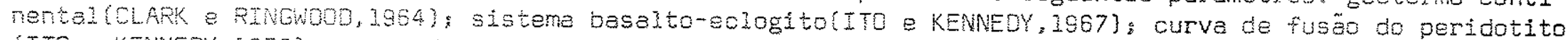
(ITO e KEMEOY.1970\}; campo de estabilidade de alguns polimorfos da silica(AKIMOTO e SYono, ig72):0urva de equilibrio diamente-grafita\{BERMAN, 1965); cempo de cristelizaça dos xenólitos de iherzolitos granulares

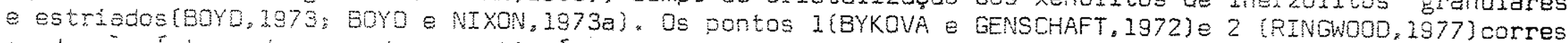
pondem á sintese de granadas constiturdas de piropo e knorringutita. Os pontos 3.4 .5 e 5 representam associaçẽes entre enstetives e diopsídios coexistentes em diemantes do kimberlito Premier, Africe do SuI (MEYER e TSAI, $1976 \mathrm{l}$. En funça desses dedos, a órea delimiteda por traços interrompidos define as condiçóes mais

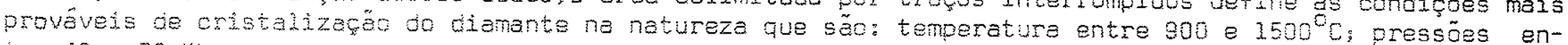
tre 40 e $70 \mathrm{kbars}$,correspondendo a profundidades da ordem de 150 a $250 \mathrm{~km}$. 
pondentes à variação do grau geotērmico em āreas de escudos: a geoterma continental calculada por CLARK e RINGWOOD (1964) e a geoterma de Lesotho resultante das investigações de NIXON e BOYD (1973) e BOYD e NIXXN (1973, 1975) com xenōlitos de kimber litos do referido paīs; 5) a posição de equilíbrio dos xenōlí tos granulares e estriados estudados por NIXON e BOYD (1973), BOYD e NIXON (1973), BOYD (1974) e DANCHIN e BOYD (1976). Os demais elementos pertinentes à Figura 26 estão representados sob a forma de pontos. Os de nümeros 1 e 2 correspondem às sinteses de crómiopiropos efetuadas respectivamente por BYKOVA e GENSHAFT (1972), e RINGWOOD (1977). Os outros pontos represen tam inclusões coexistentes em diamantes do kimberlito Premier, Africa do SUI (MEYER e TSAI, 1976a), compreendendo as seguintes assembléias mineralógicas: diopsỉdio + enstatita + crōmiopiropo (3), diopsídio + enstatita (4), diopsỉdio + enstatita (5), e diopsidio + enstatita + piropo (6).

A ocorrência simultânea de diopsỉdio e enstatita no mesmo diamante torna possivel estabelecer as temperaturas e pressões de formação das referidas inclusões, e consequentemente, do cristal hospedeiro. Os termōmetros geológicos de DAVIS e BOYD (1966) e BOYD (1973) fornecem a temperatura de cristali zação do diopsídio; o barômetro geológico de MacGREGoR (1974), por sua vez, fornece a pressão correspondente à formação de enstatita. A Tabela 18 illustra com dados extraídos de MEYER e TSAI (1976a), a aplicação do termômetro e do barōmetro geolōgico referidos. Neste exemplo, os autores mencionados determina ram as temperaturas e pressões correspondentes a formação do diamante da Mina Premier. Africa do Sul, a partir do estudo de värias associações coexistentes.

A curva tracejada da Figura 26 delimita de forma apro ximada o campo de formação do diamante na natureza. Ela ē caracterizada por temperaturas variando entre 950 a $1450^{\circ} \mathrm{C}$ e pres sões entre 40 e 75 Kbars. Essas condições correspondem a uma profundidade da ordem de 150 a $200 \mathrm{~km}$ comprovando que o diaman 
TABELA 18 - TEMPERATURAS E PRESSÕES DE FORMAÇAOO DE INCLUSÖES COE XISTENTES EM DIAMANTES DO KIMBERLiTO PREMIER, AFRICA DO SUL, SEGUNDO MEYER E TSAI, 1976 a

\begin{tabular}{lcc}
\multicolumn{1}{c}{ Assembléia coexistente } & Temperatura $\left({ }^{\circ} \mathrm{C}\right)$ & Pressão (Kbars) \\
Diopsídio + enstatita + crômiopiropo (3) & 1270 & 65 \\
Diopsĩdio + enstatita (4) & 970 & 60 \\
Diopsĩdio + enstatita (5) & 1010 & 53 \\
Diopsĩdio + enstatita + piropo (6) & 1050 & 45
\end{tabular}

te se forma realmente no manto superior. A região delimitada contēm os segmentos $G$ e E que correspondem às regiões onde os xe nōlitos granulares $(G)$ e estriados (E) se equilibram (BOYD e NIXON, 1972, 1973; NIXON e BOYD, 1973). Esse fato reforça as con clusões referentes às caracterīsticas quỉmicas das inclusões ana lisadas, que conforme ressaltamos, assemelham-se aos minerais constituintes dos lherzolitos granulares e estriados.

CONDIÇÕES QUTMICAS DE FORMAÇÃO DO DIAMANTE

Outro ponto em que hă uniformidade de pensamento entre os pesquisadores diz respeito ao crescimento cristalino do dia mante. Parece não haver dūvida que ele se opera sob condições de equilíbrio, pois de outra forma, seria dificil explicar a exis tência de diamantes bem formados, cujas dimensões, em alguns ca sos, pode alcançar vārios centīmetros. Outra evidēncia do cres cimento estāvel do diamante ē representada pelas inclusões cris talinas. A presença de minerais idiomorfos dentro do diamante, apresentando composição quĩmica constante e semelhante aos cons tituintes do kimberlito afasta qualquer possibilidade de cresci 
mento metaestāvel como aquele aventado por MITCHELL E CROCKET (1972).

Um dos resultados mais importantes dessa pesquisa ē a confirmação de que os diamantes estudados se formaram em dois ambientes quỉmicos distintos - um de natureza ultramāfica, pe ridotitica ou lherzolitica; e outro de natureza eclogitica (MEYER e SVISER0, 1975; PRINZ et al., 1975). Cada um deles é representado por um conjunto de inclusões que reunidas, consti tuem as duas assemblëias mineralögicas da Tabela 19. Essa divi são jā tinha sido mencionada na discussão referente aos clinopi roxēnios e granadas, estando bem evidenciada nas Figuras 9, 10 , $11,12,13,14,15$ e 21 .

TABELA 19 - CLASSIFICAÇÃO PARAGENETICA DAS INCLUSÖS MINERAIS IDENTIFICADAS EM DIAMANTES DO BRASIL

Assemblēia Ultramäfica

Assemblēia Eclogītica

forsterita

onfacita

enstatita

piropo-almandina

diopsĩdio

rutilo

crōmiopiropo

ilmenita

pirrotita

pirrotita

zircão

zircão

diamante

diamante

A assemblēia de inclusões ultramāficas ē formada por fases cujas caracterīsticas assemelham-se ā dos minerais consti tuintes de xenōlitos ultramāficos encontrados em diversos kim berlitos. Tais xenólitos que a maior parte dos autores admitem provir diretamente do manto superior, compreendem lherzolitos, harzburgitos, wehrlitos e websteritos - com ou sem granada -,alēm. 
de xenocristais (megacristais) de olivina, enstatita, diopsidio, granada e ilmenita (CARSWELL e DAWSON, 1970; BOYD, 1974a;SOBOLEV et al., 1975; MEYER, 1977).

A assemblēia èclogītica, como o prōprio nome sugere, reune fases que guardam semelhanças quỉmicas com os minerais constituintes de eclogitos encontrados em kimberlitos sob a for ma de xenōititos. Excetuando-se o zircão e a pirrotita as demais fases são características e constantes em cada uma das assem blēias mencionadas. A divisão paragenética da Tabela 19 estā bem comprovada pelos casos conhecidos de ocorréncia simultānea de mais de um mineral no mesmo diamante. Nos capitulos anteriores, jă haviamos feito menção às associações envolvendo olivina, ens tatita, diopsidio, crōmiopiropo e crōmioespinēlio de um lado, e piroxênio onfacita e granada piropo-almandina de outro. A ine xistência de associações entre fases ultramäficas com fases eclo giticas comprova a classificação das inclusões apresentada na Tabela 19 e mostra que o diamante se forma em dois ambientes dis tintos: um de natureza ultramäfica (peridotito) e outro de natü reza eclogitica (eclogito).

Esses resultados concordam perfeitamente com a ocorrên cia do diamante na natureza. Observações geolögicas conjugadas com registros nas principais minas indicam que $90 \%$ da produção mundial provēm diretamente de kimberlitos. 0s $10 \%$ restantes, em bora fornecidos por jazidas secundārias (conglomerados e aluviōes Recentes), tambëm derivam de kimberlitos (VERWOERD, 1970). Em outras palavras, os kimberlitos são a mais importante fonte de diamantes naturais de que o homem dispõe. Entretanto, o diaman te pode ocorrer em outras rochas alēm do kimberlito.

Sabe-se que certos meteoritos são portadores de diaman tes e que nesses casos, comumente eles se apresentam escuros, pó licristalinos e repletos de defeitos. São escassos e sua origem parece estar relacionada a processos de choques experimentados pe 10 corpo meteoritico (KEIL, 1967). Entre as rochas terrestres, a lēm do kimberlito, o diamante ocorre em dois tipos de xenōlitos 
kimberliticos: em eclogitos (WILLIANS, 1932; SOBOLEV et al., 1966; REID et al., 1976), e em peridotitos (DAWSON, 1975; MacCALLUM e EGGLER, 1976).

Normalmente, os xenōlitos de eclogitos são mais raros do que os xenōlitos ultramäficos. No caso deles serem diamantĩ feros a relação de frequẽncia inexplicavelmente se inverte. São conhecidos diversos casos de eclogitos diamantiferos (REID et al., 1976), mas apenas trēs ocorrências de xenōlitos peridotíticos con tendo diamante (SOBOLEV et az., 1969; DAWSON e SMITH, 1975; MacCALLUM e EGGLER, 1976). Não hā ainda uma explicação satisfá tōria para esse fato. 0 problema chega a ser intrigante, mormen te se levarmos em conta a abundāncia dos nōdulos ultramāficos e a semelhança de alguns deles (lherzolitos granulares e estriados) com as inclusões do diamante.

Segundo DAWSON (1976), a filiação do diamante poderia se estender a certos basaltos e dunitos relacionados a complexos ultramáficos do tipo alpino. Entretanto, do ponto de vista econōmico o kimberlito continua sendo a única fonte disponivel de diamantes naturais. Todas as demais ocorrências descritas cons tituem meras curiosidades cientificas. Em resumo, excetuando-se a ocorrēncia meteorítica, o diamante está restrito a duas para gēneses distintas: peridotĩtica e eclogitica, tal como revelado pelas inclusões.

ORIGEM DO CARBONO

A cristalização do diamante no manto superior levanta outro problema interessante relacionado a fonte e natureza do elemento químico carbono (FRANK, 1969). As opiniões divergem com alguns autores admitindo que o carbono esteja dissolvido or ginalmente no magma, enquanto outros admitem simplesmente a exis tência de $\mathrm{CO}_{2}$ dissolvido no magma ou sob a forma de uma fase flui 
da isolada. Há ainda os que postulam que a fonte de carbono no manto seja o metano (MITCHELL, 1975).

ROEDDER (1965) observou inūmeras inclusões liqquidas e gasosas de $\mathrm{CO}$ e $\mathrm{CO}_{2}$, de "dimensões micromëtricas, nos minerais constituintes de basaltos, dunitos, peridotitos, piroxênios,eclo gitos e kimberlitos. LANG (1970) sugeriu a existência de carbo no sob a forma de diamante no manto superior. Segundo esse au tor, o diamante seria um dos constituintes primārios do manto, principalmente das regiões mais profundas, ocasionalmente amos tradas por kimberlitos. DAWSON (1971) admitiu que o carbono exis tiria no manto sob a forma de carbetos. A presença de cohenita $\left(\mathrm{Fe}_{3} \mathrm{C}\right.$ ) e moissanita (SiC) em kimberlitos da Sibēria (FRANTSESSON, 1970), confirma em parte a sugestão de DAWSON.

As experiēncias de MELTON et al. (1972) e MELTON e GIARDINI (1974, 1975), parecem indicar a existência de uma sērie de compostos de carbono, nitrogênio, hidrogēnio e oxigēnio asso ciados ao diamante. Se os gases detectados pelos referidos pes quisadores estão realmente dentro do diamante ou dentro das in clusões cristalinas, conforme argumentamos em capĩtulos anterió res, pouco importa. 0 fato deles terem sido determinados rigo rosamente, mediante anālises por espectrometria de massa, compro va a existēncia de diversos compostos voläteis no manto cuja ori gem è pouco conhecida. EGGLER (1974, 1975) desenvolveu uma sērie de experimentos no Geophysical Laboratory de Washington, destina dos a esclarecer a natureza e o papel desempenhado pelo $\mathrm{CO}_{2}$ ém sistemas a altas pressões. EGGLER concluiu que o $\mathrm{CO}_{2}$ poderia existir sob a forma de uma fase isolada em associações ultramāfi cas e ultrabäsicas semelhantes a kimberlitos.

Admitindo-se que $\mathrm{O}_{2} \mathrm{CO}_{2}$ existente no magma kimberlítico seja submetido a condições fortemente redutoras semelhantes às calculadas por KENNEDY e NORDLIE (1968), poderia ocorrer a redu ção desse composto a carbono livre. 0 carbono por sua vez, sob a ação das pressões existentes a $200 \mathrm{~km}$ de profundidade se cris talizaria sob a forma de diamante (Figura 26). Segundo MARX 
(1972), a pirrotita seria o mais provāvel agente redutor do $\mathrm{CO}_{2}$, cuja transformação a diamante ocorreria de acordo com a seguinte equação:

$$
2 \mathrm{FeS}+\mathrm{CO}_{2} \rightarrow 2 \mathrm{FeO}+\mathrm{S}_{2}+\mathrm{C}
$$$$
\text { (pirrotita) }
$$

(diamante)

A hipōtese de MARX (1972) concorda com os fatos esta belecidos referentes à composição mineralōgica dos kimberlitos e das inclusões do diamante. Sabe-se de longa data que a pirroti ta e outros sulfetos são fases comuns em kimberlitos e em seus xenōlitos associados (DAWSON, 1967, 1972). No tocante às inclu sões, SHARP (1966), HARRIS (1968), FESQ et al. (1975) e GURNEY et al. (1977) mostraram que a pirrotita $\overline{\mathrm{e}}$ um mineral comum em diamantes naturais. Parece não haver düvida, portanto, de que a pirrotita $\bar{e}$ de fato uma das fases constituintes do magma ge rador do diamante.

O DIAMANTE NO BRASIL

Nos capitulos anteriores demonstramos que a gênese do diamante do Brasi1, da mesma forma que na Africa, União Soviēti ca, Venezuela, Tailändia e outros locais do mundo, estā sempré relacionada a rochas de natureza kimberlitica. Excetuando-se o caso de alguns meteoritos, todas as demais ocorrēncias de dia mante na natureza estão restritas a kimberlitos ou a xenōitios de eclogitos e peridotitos de natureza kimberiitica. 0 desco nhecimento desses fatos no passado levou alguns pesquisadores a formularem teorias exōticas sobre a origem do diamante no Brasil.

$\mathrm{Na}$ verdade, quase todos os grandes geōlogos brasile ros ocuparam-se com o problema da origem do diamante em nosso 
Paỉs. Para GORCEIX (1882), o itacolomito seria a rocha matriz do diamante na região central do Estado de Minas Gerais. DERBY (1882, 1898) propōs inicialmente uma origem ācida; posteriormen te, admitiu tambēm a possibilidade de uma origem bäsica para o diamante no Brasil. DRAPPER (1920) sugeriu a existēncia de cha minēs kimberlïticas na região de Diamantina, Minas Gerais, tendo sido contestado por GUIMARAES (1927). Analogamente, RIMANN(1917), WALLS (1919), MAACK (1926) e FREYBERG(1932) admitiram a existên cia de kimberlitos no Brasil, sem apresentarem, entretanto, ne nhuma evidēncia conclusiva para as suas idéias.

Talvez nenhum outro geölogo brasileiro tenha se dedica do ao problema da origem do diamante no Brasil com tanto entu siasmo como o Professor Djalma Guimarães. Em uma sērie de traba Thos, GUIMARAES (1927, 1930, 1932, 1961) sustentou que tanto ro chas granuliticas quanto intrusivas pegmatīticas poderiam ser a matriz do diamante da região de Diamantina, Minas Gerais. Se gundo MORAES e GUIMARAES (1932), algumas das jazidas lavradas na região de Diamantina, $M G$, conteriam "in situ" a rocha matriz do diamante. Como suporte dessa teoria, GUIMARAES citava a nature za àcida-metamōrfica dos minerais pesados (satēlites) associados aos diamantes, e a presença de quartzo dentro do diamante (CORRENS, 1931).

Entretanto, nenhum desses argumentos resiste a uma anā lise mais profunda. A ausēncia de minerais kimberiłticos entre os minerais pesados da região pode ser explicada facilmente pela baixa resistēncia química que eles apresentam ao intemperismo quimico. De fato, quase todos os minerais constituintes dos kim berlitos são ricos em magnēsio, e portanto, facilmente intemper zados (SVISERO et al., 1977). Esse fato è agravado pela idade antiga do diamante da Serra do Espinhaço. Sabe-se que a idade dos metaconglomerados da Formação Sopa-Brumadinho, a matriz se cundāria do diamante na região, ē Precambriana superior. As ma trizes kimberliticas dispersoras, certamente são ainda mais anti gas, o que explica a ausēncia de minerais típicos daqueles kim 
berlitos nos metaconglomerados e nos sedimentos deles derivados. Com relação à presença de quartzo naqueles diamantes, como jă vimos no capitulo anterior, trata-se de um problema completamen te superado, tanto do ponto de vista teórico quanto experimental.

As idēias de GUIMARAES influenciaram toda uma geração de geōlogos, e de certa forma, contribuiram para retardar os trabalhos de prospeção e pesquisa de kimberlitos no Brasil. OPPENHEIM (1936) endossou completamente a teoria de GUIMARAES, e propōs que a origem do diamante da região de Tibagi, Paranā, da mesma forma que o de Diamantina, Minas Gerais, estaria rela cionada a magmatismo ācido. BARBOSA (1951) procurou conciliar a hipótese de GUIMARAES com os fatos conhecidos das jazidas sulafricanas. Segundo BARBOSA, a matriz do diamante na região de Diamantina, Minas Gerais, seria doleritos intrusivos no Gru po Minas. Anos mais tarde, O Professor otāvio Barbosa particí paria de trabalhos sistemáticos de prospecção na região do Alto Paranaíba, que seriam coroados de éxito com a localização e ma peamento de vārias diatremas kimberlïticas (BARBOSA et al., 2976; SVISERO et al., 1977).

Refletindo a influēncia de GUIMARAES, o Professor othon H. Leonardos escrevia em 1959: "No caso de Diamantina, a idéia de uma matriz granito-pegmatitica é sugestiva, porque o diaman te dessa região mostra frequentemente inclusões de quartzo. Alēm disso seus satēlites são tipomorfos de rochas persilīcicas". Jä discutimos o carāter acidental da associação entre o diamante e alguns dos minerais pesados de natureza ācida-metamōrfica que o acompanham nas jazidas detriticas. Quanto a mencionada abundân cia de quartzo no diamante, trata-se na verdade de quartzo se cundārio introduzido nas cavidades superficiais dos cristais de diamante. Com relação ao diamante da região do Triângulo Minei ro, LEONARDOS foi mais cauteloso e admitiu a possibilidade da sua origem estar relacionada a eventos tectónicos de idade cre tācica, semelhantes àqueles que originaram os diamantes da Afr $\underline{i}$ ca do Sul. Não poderíamos omitir a opinião do Professor Silvio F. de Abreu contida em seu trabalho clássico sobre os "Recursos 
minerais do Brasil", edição de 1973, onde o referido autor afír ma: "0 que nos parece razoāvel admitir ē que o diamante possa ser originado de rochas magmäticas ācidas, bāsicas ou neutras, desde que as mesmas tenham atuado sobre sedimentos carbonosos em condições de pressão e temperatura capazes de provocar a crista lização do carbono sob a forma de diamante".

Em sintese, o que ocorreu ao nosso ver, foi uma con fusão entre causa e efeito, isto ē, entre a gênese do diamante propriamente dita e a localização das fontes kimberliticas. Na falta das referidas matrizes, GUIMARAES e os demais autores men cionados optaram por outras hipóteses que não a kimberiitica. Atualmente, essa questão estā parcialmente resolvida pois a existência de kimberlitos em diversos locais do Brasil jā ē um fato devidamente comprovado (BARBOSA et al., 1976; SVISERO et al., 1977a; SVISERO et al., 1978). Problemas desse tipo não são restritos ao Brasil. Existem depōsitos diamantiferos na Venezuela (Rios Caroni e Cuchivero), Estados Unidos da Amërica (Califörnia, Tennessee), Canadá (Quebec), India, Austrälia, nos Montes Urais e nas praias da Namíbia cujas fontes são totalmen te desconhecidas. Em todos os casos mencionados, o problema $\overline{\bar{e}}$ geológico, isto é, de campo. Não se trata de argumentar se a origem dos referidos diamantes é ou não kimberlïtica, mas sim, descobrir o posicionamento das fontes primärias dos diamantes agora encontrados sob a forma detritica. 


\section{ORIGEM DAS INCLUSOES}

Vimos, nos capitulos anteriores que as inclusões sin genēticas do diamante são minerais caracterĩsticos de altas pres sões e temperaturas. O diamante, por sua vez, com exceção de algumas ocorrēncias em meteoritos, è um mineral tipicamente kim berlitico sendo encontrado em kimberlitos ou em seus xenölitos de peridotitos e eclogitos. Verifica-se dessa forma que a or gem do diamante e das inclusões bem como dos kimberlitos, são temas conexos e dificilmente poderiam ser discutidos separada mente. Nessas condições, trataremos a origem das inclusões s multaneamente com a sequencia mais provāvel dos eventos geolög cos que conduzem à formação do diamante e do kimberlito na natu reza.

Grande parte dos conhecimentos atuais sobre a const tuição do manto superior da Terra foram desenvolvidos por BOYD e seus colaboradores no Geophysical Laboratory de Washington, a partir de estudos com xenōlitos dos kimberlitos da Africa do Sul e de Lesotho. Trabalhos semelhantes efetuados por SOBOLEV e colaboradores na União Soviētica, completam o quadro das in formações disponíveis sobre o manto superior. BOrD e NIXON (1972) apresentaram a primeira classificação química-textural dos xenōlitos associados a kimberlitos. Estudos posteriores de NIXON e BOYD (1973), NIXON et al. (1973), BOULLIER e NICOLAS (1973, 1975), MacGREGOR e BASU (1974) e MacGREGOR (1975), permi tiram estabelecer com precisão as condições de temperatura e pressão nas quais os xenōiltos ultramäficos se equilibraram.Uti 1izando dados desse tipo, BOYD e NIXON (1973, 1973a) lograram posicionar com segurança os locais de proveniências dos kimber 1 itos e dos seus xenólitos diversos.

A Figura 27 apresenta de forma esquemätica a primeira coluna estratigräfica, desde a crosta atē o manto superior. A crosta siālica com seus $50 \mathrm{~km}$ de espessura, nesse caso não tem 


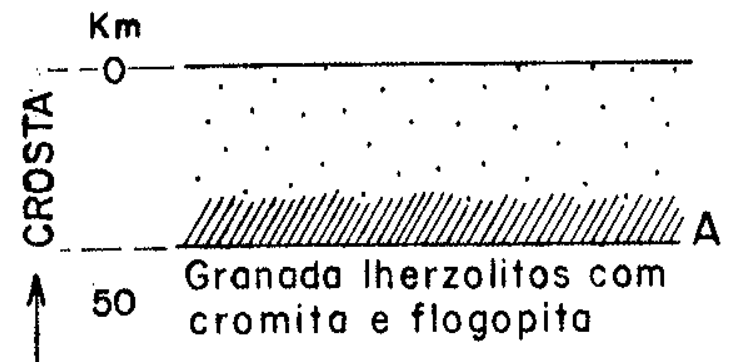

100

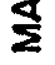

50

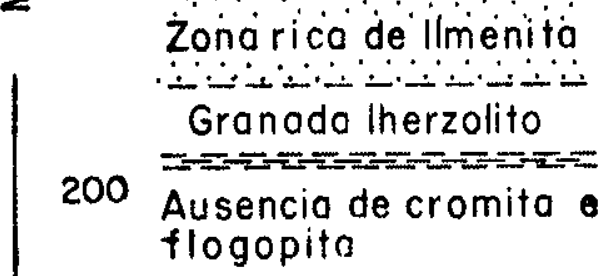

Pirólito (?)

B Zona granular

$$
\text { Granulito e eclogito }
$$$$
\text { Zona tabutar }
$$

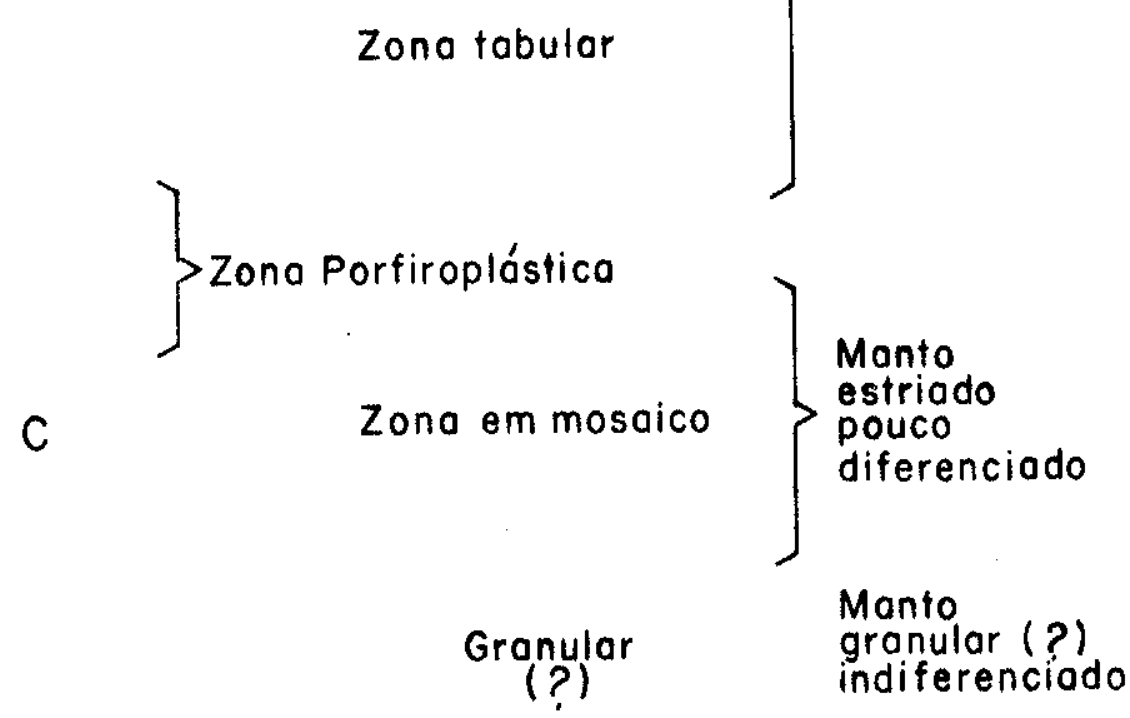

Monto gronular diferenciado

Figura 27 - Coluna estratigräfica do manto superior da região su deste do continente africano estabelecida por NIXON et al. (1973), a partir de xenólitos ultramäficos dos kimberlitos de Lesoto.Nesse esquema os primeiros 50 $\mathrm{km}$ correspondem à crosta siálica e são seguidos por zonas distintas constituidas por peridotitos de texturas variadas até a profundidade de $200 \mathrm{~km}$ aproxima damente. A partir desse nível inicia-se o manto indi ferenciado (pirólito). O ponto A representa eclogitos da base da crosta; os pontos B e C eclogitos do manto originados acima e abaixo da zona de baixa velocidade. 
qualquer interesse. Apōs a descontinuidade de Mohorovicic segue- se uma sucessão de rochas ultrabāsicas e ultramäficas (WYLLIE, 1967), subdivididas de acordo com as caracteristicas texturais ("fabric") dos minerais"constituintes (BOULLIER e NICOLAS, 1973, 1975). A faixa compreendida entre 50 a $150 \mathrm{~km}$ reune rochas di versas de textura granular (Therzolitos, harzburgitos, wehrlitos, etc.), seguindo-se uma faixa de tipos semelhantes porēm de textu ra estriada. Abaixo de $200 \mathrm{~km}$, a faixa de rochas estriadas con funde-se com o pirölito que é o material primordial do manto sü perior (RINGWOOD, 1969; DAWSON, 1972).

$\mathrm{Na}$ Figura 28 temos um esquema, em planta e perfil, da parte sul do continente africano onde estão ressaltadas as äreas pertencentes ao grande Crāton da Rodēsia-Transval (CLIFORD,1970). 0 perfil NW-SE mostra as principais relações entre a litosfera e a astenosfera na região correspondente ao Estado de Lesotho. 0 10 cal ē sem dūvida uma das āreas anōmalas do planeta pois a calizam aproximadamente 200 kimberlitos, sendo vārios deles por tadores de diamantes (DEMPSTER e RICHARD, 1973). A 1itosfera,com uma espessura mëdia de aproximadamente $150 \mathrm{~km} \overline{\mathrm{e}}$ a fonte dos xenō litos ultramäficos granulares e separa-se da astenosfera subja cente pela zona de baixa velocidade (KURITA, 1973). Essa ültima, por sua vez, ē uma faixa de espessura variāvel sujeita a intensa movimentação devido ao deslocamento das placas continentais so brejacentes. Os xenōlitos ultramäficos estriados derivam-se des sa faixa cuja principal característica é o predominio de pres sões dirigidas horizontais.

Outra feição particular da zona de baixa velocidade é a presença de fluidos diversos $\left(\mathrm{CO}_{2}, \mathrm{H}_{2} \mathrm{O}\right.$, etc.) que facilitam a fusão parcial do manto originando o magma kimberlittico (WYLLIE, 1977). No momento em que a pressão ultrapassa um valor crítico, o magma kimberlītico saturado de voläteis ē injetado na litosfe ra (pontos A, B e C). Outro elemento importante na Figura $28 \bar{e}$ a curva de equilibrio entre o diamante e a grafita. Ela situa-se ligeiramente acima da zona de baixa velocidade nas āreas 


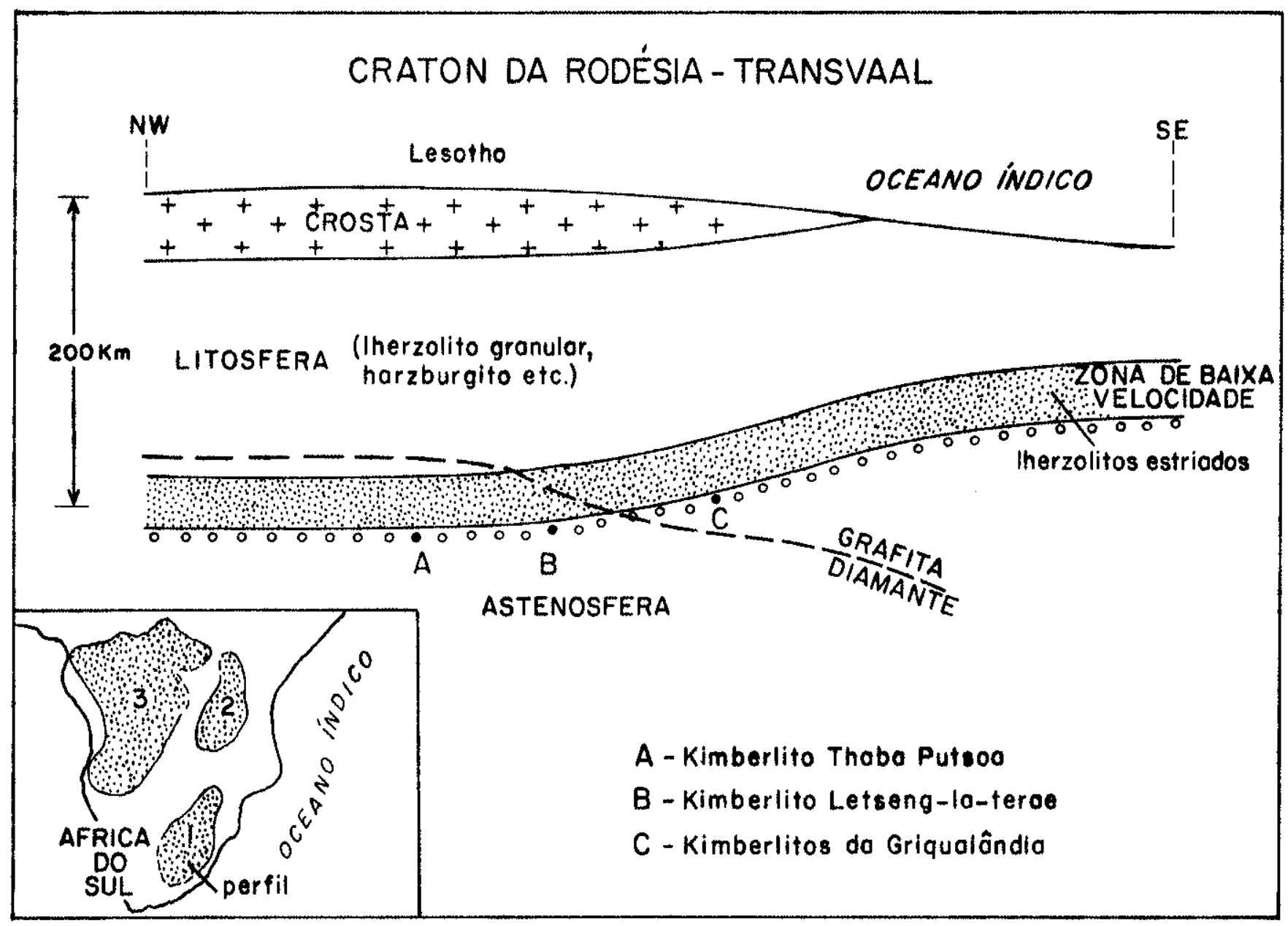

Figura 28 - Perfil NW-SE através do cráton da Rodésia-Transvaal mostrando as relações entre a litosfera e a astenosfe ra subjacente, separadas pela zona de baixa velocidade, segundo NIXON et al (1973). A curva de equilíbrio diamante-grafita situa-se ligeiramente acima da zona de baixa velocidade nas zonas de escudos e inflete pa ra o manto nas regiões oceãnicas. Ds pontos $A, B$ e $\bar{C}$ correspondem aos locais mais prováveis de origem dos kimberlitos de Thaba Putsoa (A), Letseng-la-Terae (B) e das diatremas de Griqualândia (C). 
continentais infletindo suavemente em direção ao manto nas āreas oceãnicas.

Do exame da Figura 27, verifica-se que a cristalização do diamante ocorre em profundidades prōximas de $200 \mathrm{~km}$, confirman do o que jä tinha sido estabelecido na Figura 26. 0 local exato, entretanto, $\bar{e}$ assunto sujeito a discussões. Alguns autores (MEYER, 1978: comunicação verbal) admitem que o diamante ē apenas mais um dos värios xenocristais do kimberlito. Em outras palavras,ele se forma em um estāgio prē-kimberlïtico sendo incorporado poste riormente pelo kimberlito propriamente dito. Trata-se de uma hipōtese viävel, mormente se levarmos em conta a existēncia de diamantes em xenōititos de eclogitos e peridotitos. Desde que o kimberlito engloba esses e outros tipos de enclaves em sua ascen ção pela litosfera, ele poderia englobar tambëm os diamantes pré formados em värios locais do manto.

Värias outras evịdēncias parecem indicar que o diaman te realmente não se forma no kimberlito. O'HARA e YODER (1967), HARRIS e MIDDLEMOST (1970), DAWSON (1972), CLEMENT et al. (1977) mostraram que a origem do kimberlito estā relacionada a uma fase de acūmulo de volāteis $\left(\mathrm{H}_{2} \mathrm{O}\right.$ e $\left.\mathrm{CO}_{2}\right)$ no manto superior, que em de terminado momento atinge um valor crítico desencadeando um pró cesso explosivo.

E bem provāvel que a velocidade de ascenção das diatre mas kimberliticas seja de fato muito räpida, pois de outra forma, não haveira preservação dos xenōlitos provenientes do manto. FRANCK (1969) estimou essa velocidade em $100 \mathrm{~km} / \mathrm{hora}$; McGETCHIN e ULRICH (1973), postulam em valor Mach 3, isto ē, trēs vezes a velocidade do som. Nessas condições, parece pouco provāvel que haja tempo e condições favoräveis para o diamante crescer e cons tituir cristais bem formados.

Pelo contrārio, tudo indica que na fase de colocação do kimberlito ocorra dissolução parcial ou total dos diamantes neo formados (SVISERO, 1969, 1971; WITHELOCK, 1973) pela ação de $\mathrm{CO}_{2}$ 
e de outras substāncias voläteis existentes no sistema. Essa dis solução seria facilitada pelo alīvio de pressão e consequente ele vação da temperatura resultante da subida do kimberlito. Essa hipōtese explica satisfatoriamente não sö as caracterīsticas mor fológicas particulares do diamante (face e arestas curvas, for mas indefinidas, häbitos transicionais), como tambēm sua ausēn cia na major parte dos kimberlitos conhecidos. Sabe-se que a porcentagem de kimberlitos mineralizados não ultrapassa a cifra dos 40\% (BARDET, 1973, 1974). Em sintese, ē bem provāvel que o diamante cristalize a partir de um liqquido em värios locais do manto sendo posteriormente englobado e arrastado pelo magma kim berlïtico ascendente. o local exato e a histōria pormenorizada da cristalização do kimberlito são problemas pouco conhecidos (GURNEY, 1975; ELTON e RIDLEY, 1977).

Ao discutirmos a origem das inclusões cristalinas do diamante $\bar{e}$ preciso levar em conta sua classificação paragenētica em ultramäfica e eclogĩtica, apresentada na Tabela 19. As Tabe las 20 e 21 , e as Figuras 29 e 30 sintetizam as características quimicas desses dois grupos de inclusões. As referidas Tabelas e Figuras reunem dados referentes apenas a clinopiroxēnios e gra nadas, de vez que esses minerais, alēm de constituirem fases có muns às inclusões ultramäficas e eclogīticas, exibem variaçōes significativas em suas composições refletindo a origem diversa de cada um dos referidos grupos.

A Tabela 20 compara clinopiroxēnios de natureza ultra mäfica e eclogittica identificados em diamantes do Brasil, com anālises quimicas representativas de clinopiroxēnios de diaman tes da Ärica (MEYER e BOYD, 1972; MEYER e TSAI, 1976) e União Soviētica (SOBOLEV et al., 1971, 1972a). A referida Tabela in clui tambēm clinopiroxēnios constituintes de lherzolitos granula res e estriados (NIXON e BOYD, 1973), um megacristal(xenocristal) de clinopiroxênio (BOYD e DANCHIN, 1974), e xenōlitos de eclogi tos (MEYER e BROOKINS, 1971; SOBOLEV, 1974; REID et al., 1976). Examinados em conjunto, os clinopiroxēnios ultramäficos diferem 
TABELA 20 - ANĀLISES DE CLINOPIROXENNIOS DE NATUREZA ULTRAMĀFICA E ECLOGITICA INCLUSOS EM DIAMANTES DO BRASIL, COMPARADOS COM DADOS EQUIVALENTES REPRESENTATIVOS DE XENOLITOS DE KIMBERLITOS E DE INCLUSOES DE DIAMANTE DE OUTROS LOCAIS

\begin{tabular}{|c|c|c|c|c|c|c|c|c|c|c|c|c|}
\hline \multirow{3}{*}{$\begin{array}{l}\sigma \\
X \\
I \\
D \\
0 \\
S\end{array}$} & \multicolumn{6}{|c|}{ Assemblēia ultramäfica } & \multirow{2}{*}{\multicolumn{3}{|c|}{$\begin{array}{l}\text { Assembléia } \\
\text { Inclusões de diamantes }\end{array}$}} & \multicolumn{3}{|l|}{ eclogiti } \\
\hline & \multicolumn{2}{|c|}{ Inclusões em } & diamantes & \multicolumn{3}{|c|}{ Xenólitos de kimberlitos } & & & & Xenōlito & s em ki & berlitos \\
\hline & $\begin{array}{l}\text { Brasil } \\
M G-52 a\end{array}$ & $\begin{array}{l}\text { URSS } \\
(1)\end{array}$ & $\begin{array}{l}\bar{A} \text { frica } \\
\quad(2)\end{array}$ & $\begin{array}{l}\text { Granular } \\
(3)\end{array}$ & $\begin{array}{l}\text { Estriado } \\
\quad(4)\end{array}$ & $\underset{(5)}{\text { Megacristal }}$ & $\begin{array}{l}\text { Brasil } \\
M G-65 a\end{array}$ & $\begin{array}{l}\text { Africa } \\
(6)\end{array}$ & $\begin{array}{l}\text { URSS } \\
(7)\end{array}$ & $\begin{array}{l}\text { USA } \\
(8)\end{array}$ & $\begin{array}{l}\text { Africa } \\
\quad(9)\end{array}$ & $\begin{array}{l}\text { URSS } \\
(10)\end{array}$ \\
\hline $\mathrm{SiO}_{2}$ & 55,20 & 54,6 & 55,5 & 54,71 & 55,3 & 54,2 & 54,30 & 52,9 & 54,8 & 53,3 & 55,78 & 55,6 \\
\hline $\mathrm{TiO}_{2}$ & 0,05 & 0,05 & 0,04 & 0,02 & 0,17 & 0,39 & 0,80 & 0,16 & 0,48 & 0,67 & 0,22 & 0,47 \\
\hline $\mathrm{Al}_{2} \mathrm{O}_{3}$ & 1,22 & 1,62 & 0,96 & 1,81 & 2,08 & 3,53 & 5,86 & 5,12 & 9,79 & 8,42 & 6,06 & 8,60 \\
\hline $\mathrm{Cr}_{2} \mathrm{O}_{3}$ & 1,48 & 1,88 & 0,33 & 1,29 & 0,86 & 0,51 & 0,05 & 0,02 & 0,05 & 0,07 & 0,07 & 0,05 \\
\hline $\mathrm{FeO}$ & 2,53 & 1,75 & 3,02 & 1,46 & 3,35 & 5,17 & 5,65 & 7,67 & 4,94 & 5,81 & 3,69 & 5,64 \\
\hline MgO & 18,20 & 17,3 & 21,2 & 16,99 & 21,2 & 19,0 & 11,80 & 12,6 & 8,97 & 11,1 & 14,48 & 9,78 \\
\hline $\mathrm{CaO}$ & 19,35 & 20,9 & 17,9 & 21,86 & 16,2 & 14,9 & 16,50 & 19,0 & 13,1 & 15,4 & 16,84 & 13,5 \\
\hline Mno & $<0,01$ & 0,07 & - & 0,06 & 0,11 & 0,14 & 0,02 & 0,13 & 0,07 & 0,05 & 0,06 & 0,08 \\
\hline NiO & $<0,01$ & - & 0,03 & - & - & - & 0,07 & 0,01 & - & - & - & - \\
\hline $\mathrm{Na}_{2} \mathrm{O}$ & 2,12 & 1,49 & 0,53 & 1,22 & 1,26 & 2,02 & 4,65 & 2,30 & 6,70 & 5,09 & 3,15 & 5,84 \\
\hline $\mathrm{K}_{2} \mathrm{O}$ & 0,05 & 0,13 & 0,02 & - & - & - & 0,12 & 0,01 & 0,30 & 0,01 & - & 0,08 \\
\hline Total & 100,22 & 99,7 & 99,5 & 99,42 & 100,6 & 99,9 & 99,76 & 100,0 & 99,2 & 99,9 & 100,35 & 99,66 \\
\hline
\end{tabular}
1) SOBOLEV et al.(1971a);
2) MEYER \& TSAI (1976);
3) NIXON \& BOYD (1973);

4) NIXON \& BOYD (1973);

5) BOYD \& DANCHIN (1974);

6) MEYER \& BOYD (1972);

7) SOBOLEV et al(1972a),

8) MEYER \& BROOKINS (1971);

9) REID et al.(1976);

10) SOBOLEV (1974). 
dos eclogiticos por conterem teores maiores de $\mathrm{MgO}$, $\mathrm{CaO}$ e $\mathrm{Cr}_{2} \mathrm{O}_{3}$; e valores menores de $\mathrm{TiO}_{2}, \mathrm{Al}_{2} \mathrm{O}_{3}, \mathrm{FeO}$ e $\mathrm{Na}_{2} \mathrm{O}$. No tocante às in clusões de diamantes do Brasil e de outros locais, observa-se que ambas assemblēias, ultramäfica e eclogitica, exibem grandes similaridades com os seus respectivos xenölitos kimberliticos. No caso das inclusões uitramäficas, as similaridades são mais acentuadas em relação aos xenōlitos granulares e estriados.

Comparações referentes às granadas estão apresentadas na Tabela 21. Nela, as inclusões ultramäficas e eclogiticas de diamantes do Brasil estão reunidas com anālises representati vas de inclusões referentes a diamantes da Africa (MEYER e BOYD, 1972). União Soviētica (SOBOLEV et al., 1971a) e Venezuela (SVISERO e GOMES, 1977). A referida Tabela contēm ainda grana das constituintes de Therzolitos granulares e estriados (NIXON e BOYD, 1973; SVISER0 et a2., 1977), um megacristal(xenocrista1) de granada (BOYD, 1974a) e xenōlitos de eclogitos (MEYER e BROOKINS, 1971; SOBOLEV, 1974; REID et al., 1976). De um modo geral, as granadas ultramäficas diferem das eclogiticas por con terem teores maiores de $\mathrm{Cr}_{2} \mathrm{O}_{3}$ e $\mathrm{MgO}$, e valores menores de $\mathrm{TiO}_{2}$, $\mathrm{Fe} 0$ e CaO. Repetem-se em linhas gerais; as conclusões extra das dos clinopiroxēnios, e ao mesmo tempo, ressaltam-se certas particularidades no que concerne às inclusões ultramäficas do diamante. Estas possuem teores de $\mathrm{Cr}_{2} \mathrm{O}_{3}$ relativamente altos, e valores de $\mathrm{TiO}_{2}$ e CaO baixos, quando comparadas com os xenōli tos ultramāficos.

Finalmente, as Figuras 29 e 30 sintetizam as compara ções entre clinopiroxēnios e granadas inclusos em diamantes do Brasil e de outros locais, com materiais equivalentes de nature za kimberlitica. Nos diagramas da Figura 29, os clinopiroxe् nios de natureza ultramäfica e eclogitica associados a diaman tes do Brasil, estão projetados em uma porção do quadrilātero dos piroxēnios, juntamente com inclusões equivalentes de diaman tes da Africa (MEYER e BOYD, 1972; PRINZ et al., 1975; MEYER e TSAI, 1976) e União Soviética (SOBOLEV èt al., 1971a, 1972a, 
TABELA 21 - ANĀLISES DE GRANADAS DE NATUREZA ULTRAMĀFICA E ECLOGĪTICA INCLUSAS EM DIAMANTES DO BRASIL, COMPARADAS COM DADOS EQUIVA LENTES REPRESENTATIVOS DE XENOLITOS DE KIMBERLITOS E DE INCLUSOES DE DIAMANTE DE OUTROS LOCAIS

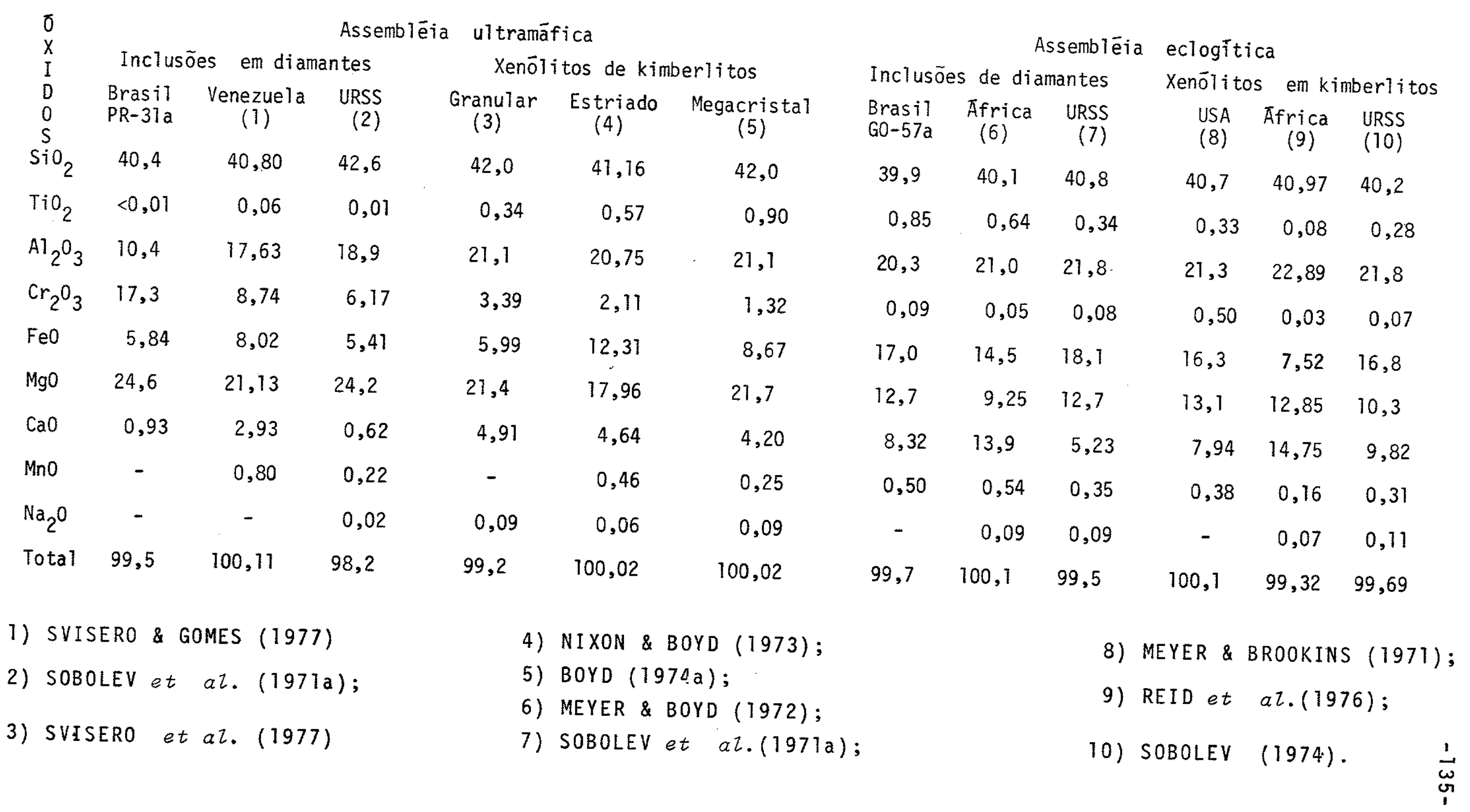


1975a; SOBOLEV, 1974). Nas referidas Figuras, estão delimitados de forma esquemática, os campos correspondentes aos xenölitos de lherzolitos granulares e estriados (BOYD e NIXON, 1972, 1973, 1973a; NIXON e BOYD, 1973) megacristais ou xenocristais de clino piroxēnios associados a kimberlitos (BOYD, 1974a), e xenōlitos de eclogitos tambēm kimberliticos (MEYER e BROOKINS, 1971; SOBOLEV, 1974; REID et al., 1976; MEYER, 1977). O diagrama 29 A contēm ainda as temperaturas correspondentes ao "solvus" enstatita-diop sidio, referentes a pressão de 30 Kbars (DAVIS e BOYD, 1966). Ape sar de algumas pequenas superposições, os xenōlitos possuem cam pos distintos, refletindo condições de gênese tambēm distintas.

os iherzolitos granulares (Figura 29A) exibem varia ções relativamente pequenas no que diz respeito às razões $\mathrm{Ca} / \mathrm{Ca}+$ $+\mathrm{Mg} \mathrm{e} \mathrm{Mg/Mg} \mathrm{+} \mathrm{Fe.} \mathrm{Suas} \mathrm{temperaturas} \mathrm{de} \mathrm{cristalização} \mathrm{situam-se}$ na faixa $900-1100^{\circ} \mathrm{C}$, correspondendo aos valores mais baixos en tre os xenōlitos ultramäficos. Os demais xenōlitos desse grupo, incluindo os lherzolitos estriados e os megacristais ou xenocris tais de clinopiroxênios, exibem variações mais amplas e semelhan tes em suas razões $\mathrm{Ca} / \mathrm{Ca}+\mathrm{Mg}$. Ambos equilibram-se em uma faixa ampla de temperaturas que podem alcançar $1450^{\circ} \mathrm{C}$. Diferem em suas razões $\mathrm{Mg} / \mathrm{Mg}$ + Fe devido ao fato dos megacristais conterem proporções maiores de ferro II do que os lherzolitos estriados. As inclusões ultramäficas do diamante, incluindo dados do Brasil e de outros locais, espalham-se pelos campos correspondentes aos Therzolitos granulares e estriados comprovando as similaridades genēticas entre esses materiais.

o campo dos xenōlitos de eclogito (Figura 29B) é mais amplo do que o dos demais xenólitos, e inclui perfeitamente os dados referentes aos clinopiroxénios inclusos em diamantes do Brasil e de outros locais. No grupo eclogitico, tanto as inclu sões de diamante quanto os xenōlitos de eclogito, apresentam va riação ampla no tocante as razões $\mathrm{Ca} / \mathrm{Ca}+\mathrm{Mg} \mathrm{e} \mathrm{Mg} / \mathrm{Mg}+\mathrm{Fe}$.

As variações referentes às granadas de natureza ultra māfica e eclogitica estão sintetizadas nos diagramas de variação 


\section{ASSOCIACĀO ULTRAMÁFICA}

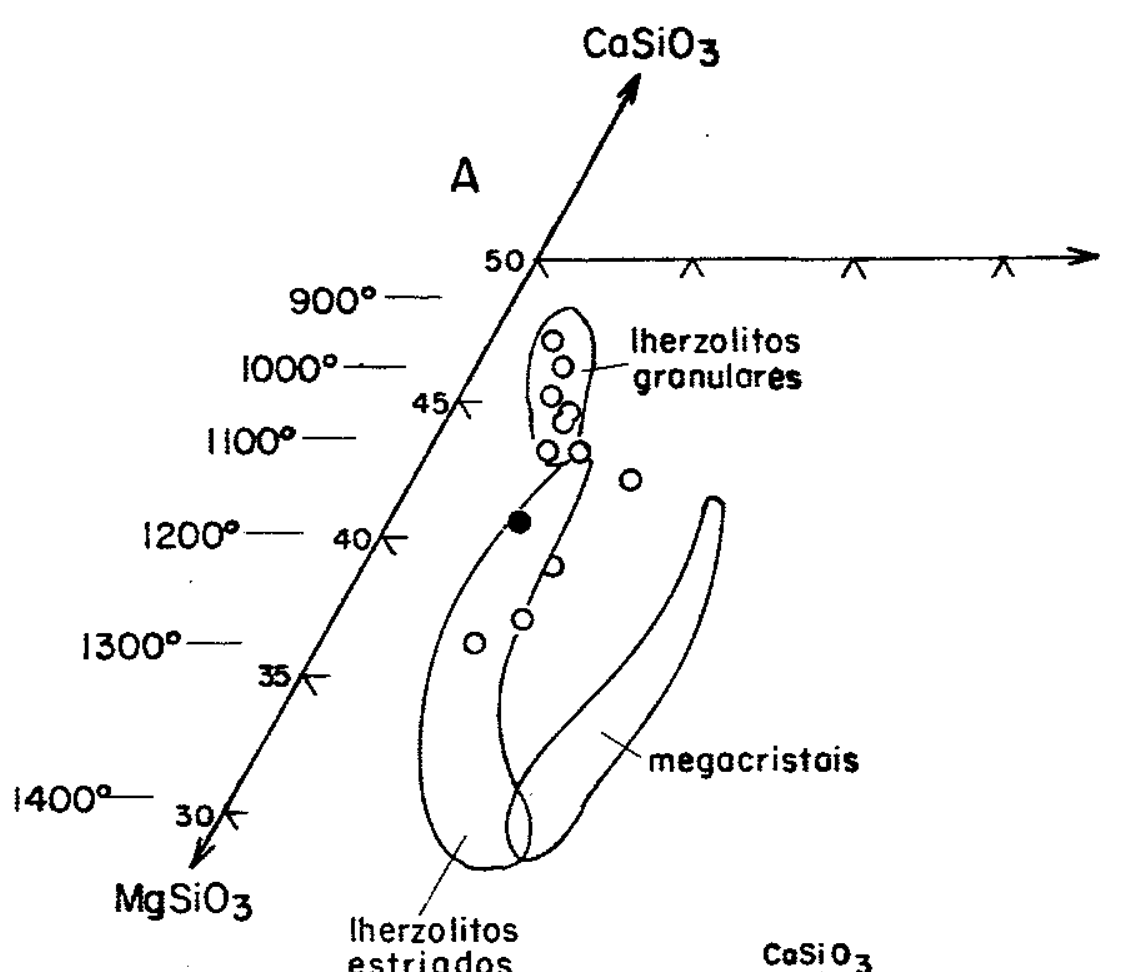

estriados
ASSOCIACÃO ECLOGÍTICA

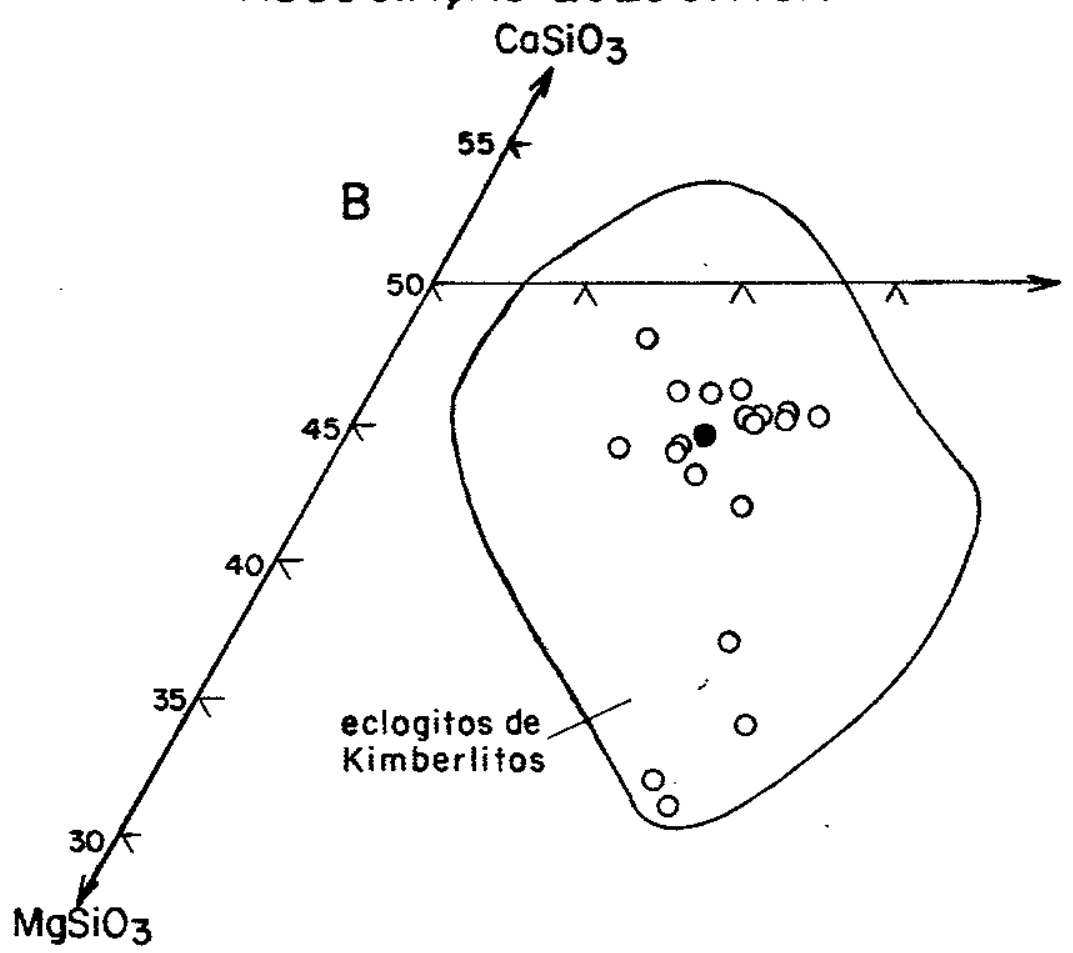

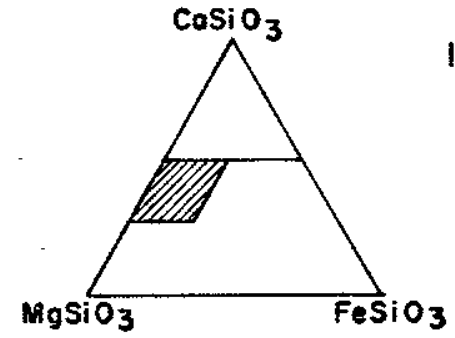

INCLUSÕES EM DIAMANTES

- Brasil

- Áfrico e URSS

Figura 29 - Clinopiroxênios de natureza ultramáfica e eclogítica inclusos em diamantes do Brasil. comparados com material equivalente de diamantes da Africa do Sul e União Soviética. Os diagramas contém de forma esquemática os campos dos xenálitos de lherzolitos granulares e estriados, xenocristais (megacristais) de clinopiroxenios, e eclogitos kimberliticos. As inclusões de natureza ultramáfica associadas a diamantes do Brasil e de outros locais projetam-se simultaneamente no campo dos lherzolitos granulares e estriados; as de natureza eclogitica caem perfeitamente dentro do campo dos eclogitos. As temperaturas correspondentes ao "solvus" diopsidio-enstatita foram extraídas de DAVIS e BOYD(1966), e os demais dados comparativos de MEYER e BROOKINS (1971); BOYD e NIXON (1972, 1973,1973a); MEYER E BOYD (1972); NIXON E BOYD (1973); BOYD (1974a); SOBOLEV et al(1971a,1972a,1975a); SOBOLEV (1974); PRINZ et aZ(1975); MEYER \& TSAI (1976); REID et al(1976); MEYER(1977). 
ternāria Ca-Mg-Fe $\mathrm{C}^{2+}$ da Figura 30 . Eles incluem as inclusões identificadas em diantes do Brasil, Africa (MEYER e BOYD, 1972; PRINZ et al., 1975; MEYER e TSAI, 1976), União Soviētica(SOBOLEV et al., 1971, 1972; SOBOLEV, 1974) e Venezuela (SVISERO e GOMES, 1977). Repetindo o procedimento adotado com os clinopiroxénios, os diagramas da Figura 30 contēm de forma esquemática, os cam pos de variação referentes às granadas dos lherzolitos granulares e estriados (BOYD e NIXON, 1972, 1973a; NIXON e BOYD, 1973), megacristais ou xenocristais de granadas associadas a kimberli tos (BOYD, 1974a) e granadas constituintes de xenólitos de eclo gitos tambëm kimberlïticos (MEYER e BROOKINS, 1971; SOBOLEV,1974; REID et al., 1976).

No grupo ultramāfico (Figura 30A), não hã uma distin ção perfeita entre os lherzolitos granuiares e estriados tal co mo foi observado no caso dos clinopiroxênios. Já os megacris tais de granada constituem um campo distinto caracterizado por variações significativas da razão $\mathrm{Mg} / \mathrm{Mg}+\mathrm{Fe}$. Com relação às granadas ultramāficas inclusas em diamantes do Brasil e de ou tros locais, algumas projetam-se nos campos correspondentes aos Therzolitos granulares e estriados. Entretanto, a maior parte dessas inclusões constitui um campo independente cujas razões $\mathrm{Mg} / \mathrm{Mg}+\mathrm{Fe}$ e $\mathrm{Ca} / \mathrm{Ca}+\mathrm{Mg}$ são ligeiramente distintas daquelas re ferentes aos xenōlitos. Com relação às granadas de natureza eclogitica (Figura 30B), repetem-se as relações jă observadas em tre os clinopiroxēnios pertencentes à assemblēia eclogitica. 0 campo dos xenōlitos de eclogito apresenta variações significati vas em relação aos três elementos principais,.cālcio, magnésio e ferro II, e, acomoda de forma perfeita as inclusões de grana da de natureza eclogitica.

Em sintese, as inclusões de natureza eclogitica iden tificadas em diamantes do Brasil são quimicamente equivalentes aos minerais constituintes de xenōlitos de eclogito presentes em kimberlitos (Figuras 10,13,14, 15, 21, 29 e 30). Com rela ção às inclusões ultramäficas, o problema ē mais complexo.Todas 


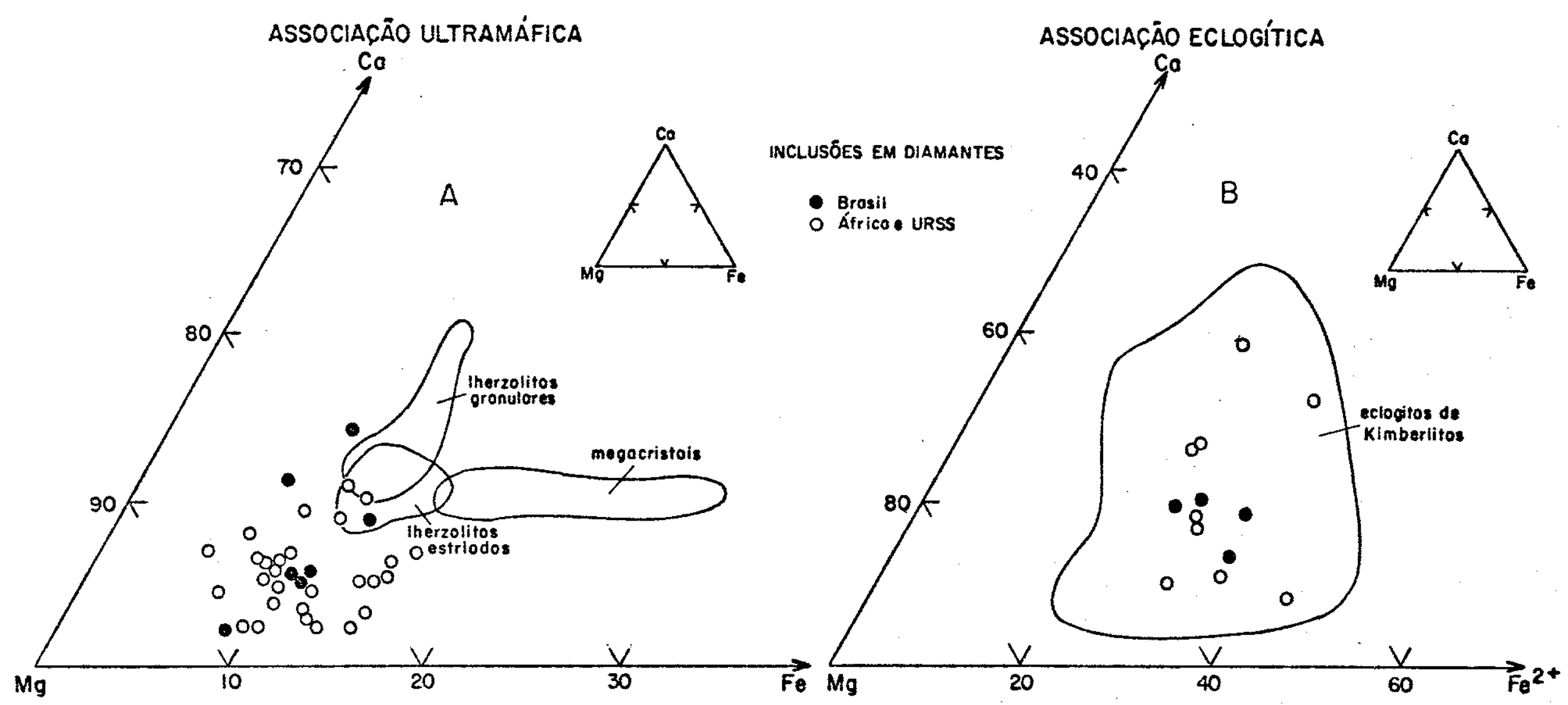

Figura 30 - Granadas de natureza ultramáfica e eclogitica inclusas em diamantes do Brasil compara das com material equivalente de diamantes da Áfica do Sul e União Soviética. Os diagra mas contém de forma esquemática os campos dos xenólitos de lherzolitos granulares e es= triados, xenocristais (megacristais) de granada, e eclogitos kimberlíticos. Tal como na Figura 29 , as inclusões de natureza ultramáfica associadas a diamantes do Brasil e de outros locais projetam-se simultaneamente dentro ou próximo do campo dos lherzolitosgra nulares e estriados; as de natureza eclogitica caem perfeitamente dentro do campo dos eclogitos. Dados comparativos extraídos de MEYER e BROOKINS (1971); BOYD e NIXON (1972. 1973, 1973a), MEYER e BOYD (1972). NIXON e BOYD (1973); BOYD (1974a); SOBOLEV et al(1971a, 1972a, 1975a); SOBOLEV (1974); PRINZ et al (1975); MEYER e TSAI (1976); REID et al(1976); $\frac{i}{\omega}$ MEYER $(1977)$. 
as relações analîticas estudadas (Figuras $4,5,6,8,10,13,14$, $15,16,19,29$ e 30) revelaram que essas inclusões são semelhan tes, simultaneamente aos minerais dos inerzolitos granulares e estriados encontrados em kimberlitos. Entretanto, as inclusões ultramäficas do diamante apresentam certas particularidades, es pecialmente no tocante a presença de crômio, que fazem delas um grupo único de minerais sem correspondēncia completa com ne nhuma rocha terrestre.

Segundo o Professor MEYER (1978: comunicação pessoal), as inclusões ultramāficas não tem equivalentes químicos devido ao fato delas cristalizarem em um estägio precoce que ele chama de fase pré-kimberlitica. Ao serem englobadas pelo diamante, elas são isoladas do liquido cujo fracionamento conduz às demais associações ultramäficas tîpicas,por exemplo, lherzolitos, harz burgitos etc., com composições ligeiramente diferentes das inclusões. Essa hipótese jä havia sido aventada por SVISERo e VALARELLI (1977), ao estudarem a partição entre magnēsio e fer ro II em olivinas e enstatitas coexistentes em diamantes (Figura 25). Esses autores mostraram que as inclusões ultramäficas são os primeiros minerais a cristalizar no magma peridotitico.

Evidentemente, o assunto não estā esgotado e continua ră sendo objeto de pesquisas por longo tempo. Ainda recentemen te, DAWSON e STEPHENS (1975) tentaram subdividir o grupo das inclusões ultramáficas do diamante, baseados em anālises de va riações estatisticas referentes a elementos quĩmicos principais. Segundo esses autores, a classificação atual das inclusões - ul tramáfica e eclogitica - seria excessivamente simplificada para traduzir todos os fenōmenos relacionados com a gēnese das inclu sões e do diamante. Na verdade, DAWSON (1976) jă abriu a ques tão ao admitir que a filiação genética do diamante é muito mais ampla do que se pensa atualmente. Respostas para esses e outros problemas referentes a origem dos materiais do manto superior, certamente serão obtidos no futuro à medida que ampliarmos nos sos conhecimentos sobre as inclusões do diamante. 


\section{RESUMO E CONCLUSOEES FINAIS}

Nos capitulos anteriores, apresentamos e discutimos uma sērie de dados cristalogrä́ficos, mineralōgicos, químicos e geolögicos referentes a quase 50 inclusões minerais identifica das em diamantes provenientes das principais zonas de garimpos do Brasil. Investigamos apenas diamantes detriticos, jă que não conhecemos, atë o presente momento, nenhum kimberlito mine ralizado em nosso Paĩs.

Os diamantes contendo inclusões, coletados de forma a representar o major nümero possĩvel de centros de garimpagem, in cluem material procedente das Bacias Hidrogräficas dos Rios Tí bagi, PR; Sapucai-Mirim, SP; Paranaỉba, Jequitinhonha e Abaeté, MG; Paraguaçu, Ba; Araguaia, Garças, São Lourenço Taquari, Ari puanã e Cuiabã, MT; Caiapó e Verde, Go; Tocantins, PA; e Rió Machado, RO (Figura 1).

As inclusões, liberadas mecanicamente pela fragmenta ção de aproximadamente 150 diamantes, previamente selecionados, foram identificadas pela combinação simultānea de microscopia öptica, difração de raios $x$ e principalmente, pela microssonda eletrōnica que forneceu tambēm a composição quīmica quantitati va de todos os minerais estudados. 0 conjunto dos minerais sin genëticos presentes nos diamantes brasileiros $\vec{e}$ constituído de olivina (forsterita), ortopiroxēnio (enstatita), clinopiroxênios (diopsidio e onfacita), granadas (crōmiopiropo e piropo-almandi na), crōmioespinēlio, rutilo, zircão ilmenita, pirrotita e o prô prio diamante (Tabela 1$)$.

Como características gerais, os minerais acima mencio nados exibem idiomorfismo acentuado, cor bem definida e constan te para cada espēcie, e dimensões variāveis entre 100 e .800 mícrons. Frequentemente, as inclusões apresentam-se circunda das por zonas birrefringentes, fraturas radiais e outros defei tos estruturais resultantes da pressão exercida pelo cristal in 
cluso sobre o diamante hospedeiro (Fotomicrografia 1). Crescimen tos epitāxicos entre o diamante e suas inclusões são tambēm fré quentes. Determinações analiticas processadas na microssonda eletrōnica indicaram composição quỉmica constante, ausência de zoneamentos e de associações pluriminerālicas contíguas entre os minerais inclusos no diamante. Associações biminerälicas,ou seja, a ocorrēncia de duas inclusões distintas no mesmo diaman te são relativamente comuns. Os pares observados incluem oli vina + enstatita, olivina + crōmiopiropo, olivina + crōmioespinēlio, e enstatita + crōmiopiropo (Tabelas 3, 5, 8 e 10, e Figu ra 24 ).

01 ivina, a inclusão mais comum nos diamantes brasile $\underline{i}$ ros apresenta-se sob a forma de cristais prismāticos, tabulares ou em forma de gota (Micrografias eletrōnicas 1, 2, 3, 4 e 5), cuja coloração varia entre verde clara a incolor. Suas razões $\mathrm{Mg} \times 100 / \mathrm{Mg}+\mathrm{Fe}$ se restringem ao intervalo 92-95\%, indicando tratar-se de olivinas ricas em forsterita (Tabelas 3 e 4 ). Esses valores são idênticos aos de olivinas componentes de lherzolí tos de textura granular encontrados em kimberlitos sob a forma de xenōlitos (Figura 4). Entre as impurezas menores, destaca- se o crômio cujos teores figura entre os mais altos para olivi nas terrestres sendo superados apenas por olivinas constituin tes de komatyitos (Figura 5).

As inclusões de piroxēnios incluem orto e clinopiro xênios. Os primeiros são semelhantes às olivinas exibindo häbí to prismātico (Micrografias eletrōnicas 6 e 7 ), cor verde clara a incolor e teores reduzidos no que diz respeito aos elementos quỉmicos secundārios. Caracterizam-se por razões $\mathrm{Mg} \times 100 / \mathrm{Mg}+$ $+\mathrm{Fe}$ quase constantes cujos valores, variāveis entre 93-94\%, in dicam predominio absoluto da molëcula de enstatita (Tabelas 5 e 6). Os clinopiroxēnios, incluindo diopsídio e onfacita consti tuem inclusões raras nos diamantes brasileiros. Ambos exibem cor verde esmeralda que $\bar{e}$ mais intensa na onfacita. 0 diopsí dio ocorre sob a forma de cristais prismäticos (Micrografia ele 
trônica 8), enquanto a onfacita constitui intercrescimentos com o diamante hospedeiro (Fotomicrografia 3 ). Do ponto de vista químico o diopsîdio diferencia-se da onfacita por conter teo res de $\mathrm{Cr}_{2} \mathrm{O}_{3}$, $\mathrm{MgO}$ e CaO maiores, e valores menores de $\mathrm{TiO}_{2}$, $\mathrm{Al}_{2} \mathrm{O}_{3}, \mathrm{FeO}$ e $\mathrm{Na}_{2} \mathrm{O}$ (Tabela 7 ). De acordo com os termómetros geo lögicos conhecidos, os clinopiroxênios cristalizam-se a tempera turas entre 1050 e $1150^{\circ} \mathrm{C}$ (Figuras 9, 10 e 29). Tal como as olivinas, os ortopiroxēnios assemelham-se ortopiroxēnios cons tituintes de lherzolitos granulares (Figuras 6 e 8 ). Entre os clinopiroxēnios, as relações são mais complexas. Uma das inclu sões assemelha-se a clinopiroxēnios de lherzolitos granulares e estriados; a outra, a clinopiroxēnios de xenólitos de eclogitos de natureza kimberlitica (Figuras 10 e 29).

Granadas, as inclusões mais frequentes depois das olivinas, constituem dois grupos portadores de propriedades fí sicas e quimicas distintas e inconfundīveis. 0 grupo mais nume roso, denominado crōmiopiropo, ē formado por cristais de hābi tos variados, em geral globulares (Micrografia eletrōnica 9), cuja coloração varia de vermelha intensa à vinho, violeta e ver de escura. Essas granadas contēm teores altos de $\mathrm{MgO}$ e $\mathrm{Cr}_{2} \mathrm{O}_{3}$ (Tabela 8 ), sendo constituīdas essencialmente pelas molēculas p ropo $\mathrm{Mg}_{3} \mathrm{Al}_{2}\left(\mathrm{SiO}_{4}\right)_{3}$, e knorringuita. $\mathrm{Mg}_{3} \mathrm{Cr}_{2}\left(\mathrm{SiO}_{4}\right)_{3}$

( T $\underline{\text { a }}$ bela 9). 0 segundo grupo, bem menos frequente, reune granadas de cor laranja a mel. Diferenciam-se do grupo anterior por con terem teores maiores de $\mathrm{TiO}_{2}, \mathrm{Al}_{2} \mathrm{O}_{3}, \mathrm{FeO}$ e $\mathrm{CaO}$, ao lado de való res reduzidos de $\mathrm{Cr}_{2} \mathrm{O}_{3}$ (Tabela 8 ). Tais granadas são designa das genericamente piropo-almandina em alusão ao predomīnio de $\underline{s}$ sas duas molëculas (Tabela 9). Comparadas a outros materiais de natureza kimberlītica, as crômiopiropo assemelham-se a grana da constituinte de xenōlitos de lherzolitos granulares e estria dos; o grupo piropo-almandina, por sua vez, ē equivalente à gra nadas de xenōlitos de eclogitos (Figuras 13, 14 e 15). Nas crō miopiropos, o crōmio substitui o alumīnio, cuja entrada na rede cristalina exige o concurso de altas pressões (Figura 16). $\bar{A}$ medida que aumenta o teor de crômio, aumenta tambēm o ĩndice de 
refração dessas granadas (Figura 17).

As demais inclusões são menos frequentes sendo algumas de ocorrência esporādica em diamantes brasileiros. 0 crōmioespi nélio forma cristais globulares (Micrografia eletrônica 13), de cor castanha escura, geralmente coexistentes com olivina e grana da. Caracterizam-se por teores altos de $\mathrm{Cr}_{2} \mathrm{O}_{3}$ (Tabela 10), sen do em linhas gerais semelhantes a crômioespinêlios de lherzolitos granulares (Figura 19). Inclusões de rutilo exibem cor castanha intensa e hābito prismātico, acentuadamente alongado segundo a direção do eixo cristalogräfico c (Micrografia eletrônica 14). As características quĩmicas dessas inclusões são semelhantes a de rutilos constituintes de eclogitos kimberliticos (Figura 21). Zircão é outra inclusão rara; desenvolve cristais de cor amarela clara, häbito prismätico (Micrografia eletrônica 16), praticamen te isentos de impurezas quỉmicas (Tabela 13). A ilmenita exibé häbito prismätico (Micrografia eletrōnica 17), cor negra e bri Tho submetālico intenso. Difere de ilmenitas presentes em xenōi tos ultramāficos por conter teores baixos de magnésio e crômio (Tabela 14, Figuras 22 e 23). Pirrotita,o ünico sulfeto identi ficado nos diamantes estudados, apresenta-se sob a forma de cris s tais irregulares (Micrografias eletrónicas 18 e 19), de cor amarela escura e brilho metālico. A composição inclui alēm do fer ro e do enxofre, níquel, cobre e crômio (Tabela 16). Inclusões de diamante no prōprio diamante são frequentes. Entretanto, a identificação ē difĩcil devido as semelhanças entre a inclusão e o respectivo hospedeiro.

Comparadas entre si, as diversas inclusões minerais identificadas nos diamantes brasileiros apresentam composição quỉmica constante. Resultados idênticos são observados quando as referidas inclusões são correlacionadas com materiais equiva lentes associados a diamantes da Africa do Sul, Gana, Serra Leoá, Tanzânia, Venezuela, Urais e Sibëria (União Soviética) e Tailân dia (Figuras 4, 6, 7, 9, 11, 12, 18, 21, 29 e 30). Essa unifor midade na composição ë realmente significativa mormente se levar 
mos em conta que a maior parte das äreas acima mencionadas, dis tam uma das outras värios milhares de $\mathrm{km}$. Ao que tudo indica,as condições de formação do diamante nessas partes do globo devem ter sido, em linhas gerais, semelhantes.

As inclusões estudadas neste trabalho podem ser reuni das em duas assemblēias mineralögicas distintas: uma delas, a mais numerosa, ē formada por minerais cuja composição quĩmica ē semelhante a dos minerais constituintes de xenōlitos ultramāfí cos de kimberlitos; a outra, menos frequente, reune fases equiva lentes quimicamente aos minerais dos xenōlitos de eclogito de na tureza kimberlitica (Figuras 4, 5, 6, 8, 10, 13, 14, 15, 16, 19, 21, 29 e 30). 01ivina, enstatita, diopsīdio, crōmiopiropo e crô mioespinëlio constituem as fases caracterīsticas da assemblëia de inclusões ultramäfica; onfacita, piropo-almandina, rutilo e ilme nita, por sua vez, formam a assemblëia eclogïtica. A pirrotita e o diamante são fases comuns às duas assemblēias. Quanto ao zir cão, sua natureza e origem ē ainda motivo de discussões (Tabelà 19). Outro ponto a enfatizar è que os diversos minerais das duas assembléias mencionadas nunca coexistem no mesmo diamante. Verifica-se, portanto, que os diamantes do Brasil, da mesma for ma que os de outros locais, cristalizaram-se em dois ambientes quỉmicos distintos: um de natureza ultramäfica peridotïtica e outro de natureza eclogitica (Figura 24).

Todas as inclusões singenēticas investigadas neste tra balho são minerais caracterỉsticos de altas pressões e temperatú ras. As olivinas e as enstatitas, de acordo com os seus coefi cientes de partição relativos aos elementos magnēsio e ferro II, cristalizam-se dentro de uma faixa de pressões e temperaturas equi valentes a dos xenōlitos ultramäficos de kimberlitos (Figura 25). os clinopiroxênios, a julgar pelos termômetros geológicos dispo nïveis na literatura, equilibram-se a temperaturas entre $1050^{\circ}$ e $1150^{\circ} \mathrm{C}$ (Figuras 9, 10, 29). Granadas crômiopiropos possuem com posições equivalentes à de granadas cujas sīnteses exigem pres sões da ordem de 60 Kbars e temperaturas de $1450^{\circ} \mathrm{C}$ (Figura 26). 
De modo anālogo, as demais inclusões possuem composições compa tỉveis com altas pressões e temperaturas. Esses e outros parâa metros relacionados no manto superior indicam que os diamantes portadores das referidas inclusões cristalizaram-se a temperatu ras entre $950^{\circ}$ e $1450^{\circ} \mathrm{C}$, e pressões da ordem de 40 a $70 \mathrm{Kbars}$ (Figura 26). Tais condições são encontradas a profundidades de 150 a $230 \mathrm{~km}$, ou seja, na zona de transição entre a base da $1 \underline{\mathbf{i}}$ tosfera e o topo da astenosfera. Entre ambas, situa-se a zona de baixa velocidade de onde, provavelmente, se origina o magma kimberlîtico, o diamante e suas inclusões (Figuras 27 e 28). Con clui-se, portanto, que a origem do diamante do Brasil, da mesma forma que o de outros locais do globo, ē de origem kimberlitica. Esse e outros resultados afastam definitivamente qualquer poss $\underline{i}$ bilidade de uma origem a partir de rochas äcidas e intermediārias, conforme foi admitido por diversos geōlogos no passado.

Ao finalizar, não poderíamos deixar de ressaltar a im portância das inclusões singenēticas do diamante, que ao ladc dos xenōlitos de kimberlitos, constituem a ünica forma de amos tragem do manto. Devido ao fato das inclusões serem englobadas pelo diamante logo no início da sua cristalização, e permanece rem isoladas dos fenômenos subsequentes que culminam com a coló cação do kimberlito na crosta, elas representam, talvez, o mate rial mais primordial do manto que jā alcançou a superfície ter restre. Nesse sentido, elas continuarão sendo um tema de pes quisa obrigatōrio no futuro, especialmente para os geocientis tas interessados nos inümeros e fascinantes problemas do manto superior. 


\section{AGRADECIMENTOS}

Diversas pessoas e Instituições colaboraram com o au tor durante a elaboração deste trabalho.

0 Professor Doutor Henry 0.A. Meyer, do Departamento de Geociencias da Purdue University, West Lafayette, Indiana, Estados Unidos da América, franqueou seus laboratōrios de raios $x$, microscopia óptica e eletrōnica, e microssonda eletrōnica; além disso, auxiliou pessoalmente o autor em diversas ocasiões durante a fase de obtenção dos dados analiticos.

Os Professores Doutor William Gerson Rolim de Camargo, Doutor Josē Moacyr Vianna Coutinho, Doutor Fernando Flävio Mar ques de Almeida, Doutor Nabor Ricardo RUlegg, Doutor Josē Vicen te Valarelli, Doutor Vicente Antonio Vitörio Girardi e Doutor Yociteru Hasui, todos do Instituto de Geociências da Universida de de São Paulo, por diversas vezes discutiram com o autor á maior parte dos assuntos tratados nesta tese.

A Fundação de Amparo à Pesquisa do Estado de São Pau Io forneceu apoio financeiro que permitiu ao autor estagiar du rante um ano na Purdue University, ocasião em que desenvolveu a maior parte dos dados analiticos aqui discutidos. 0 conselho Nacional de Desenvolvimento Científico e Tecnolögico - CNPq con cedeu auxilio financeiro para viagens ao campo e uma Bolsa de Iniciação Científica ao Senhor Carlos E.S. Pontes, aluno do Cur so de Geologia da Universidade de São Paulo.

A Senhora Nair de Campos Louzada e Senhor Josē Ponchi rolli datilografaram os originais que foram compostos e impres sos pelo Senhor Jaime Silva na Seçăo Gräfica do IG/USP.

A todos, o autor expressa seus mais sinceros agradeci mentos. 
BIBI.IOGRAFIA

ABREU,S.F. (1973) - Recursos minerais do Brasiz. Vo1.I, 324 p. Edição revisada e atualizada por J.C.Mendes e R.R.Franco, Edit. Blücher, São pauto.

AKIMOTO,A. e SYONO,Y. (1971) - The coesite-stishovite transition. In: Accurate characterization of the high-pressure environment. Spec.Pub1.no 326, p.273-277, ed.Lloyd, London.

ALLSOPP,H.L. e KRAMERS,J.D. (1977) - Rb-Sr and U-Pb age determinations on southern african kimberitie pipes. Proc. 2nd Int.Conference on Kimberlites p.11-13, Santa Fe, New México, U.S.A.

BARBOSA,0. (1951) - Contribuigão ao estudo da origem do diamante de Diamantina, Minas Gerais. Boletim nọ 136, Departamen to Nacional da Produçäo Mineral, $35 \mathrm{p}$., Rio de Janeiro. BARBOSA,0.; SVISERO,D.P. e HASUI,Y. (1976) - Kimberlitos da região do Alto Paranaiba, $M G$. Bol.Res.290 Congresso Soc. Bras.Geol., Ouro Preto-Belo Horizonte, p.323.

BARDET,M.G. (1973) - Geologie du diamant. Memoires du B.R.G.M. nọ 83,235 p., orleans cedex.

BAUER,M. (1904) - precious stones. Reprint of translation by $L$. J.Spencer, New York, Dover (1968).

BERMAN,R. (1965) - Thermal properties. In: Physical Properties of Diamond. Ed.R.Berman, Clarendon Press, Oxford,443 $\mathrm{p}$. BLOOMER,A.G. e NIXON,P.H. (1973) - The geology of Letseng-Za-terae kimberlite pipes. In: Lesotho kimberitites. p.20-38, ed. by P.H.Nixon, Lesotho Nat.Dev.Corp., Maseru.

BOULLIER,A.M. e NICOLAS,A. (1973) - Texture and fabric of peridotite nodules from kimberlite at Mothae, Thaba Putsoa and Kimberley. In: Lesotho Kimberitites p.57-66, edited by P.H.Nixon, Lesotho Nat.Dev.Corp., Maseru.

BOULLIER,A.M. e NICOLAS,A. (1975) - Classification of textures and fabrics of peridotite xenoliths from south African kimberlites. Physics and Chemistry of Earth, vol.9, p. 467-476. 
BOYD,F.R. (1969) - Electron-probe study of diopside inclusions from kimberlite. Amer.Journ. of Sci., vol.267(A),p.50-69 BOYD,F.R. (1973) - The pyroxene geotherm. Geochim. et Cosmochim. Acta, vol. 37, p.2533-2546.

BOYD,F.R. (1974) - olivine megacrysts from the kimberlites of the Monastery and Frank Smith mines, South Africa. Carnegie Inst. Wash., Yearbook 73, p. 282-285.

BoYD,F.R. (1974a) - Ultramafic nodules from the Frank Smith Kimberlite pipe, South Africa. Carnegie Inst.Wash., Vearbook 73, p.285-294.

BOYD,F.R. e CLEMENT,C.R. (1977) - Compositional zoning of olivine in Kimberlite from the De Beers Mine, Kimberley, South Africa. Carnegie Inst. Wash., Yearbook 76, p.485-493.

BOYD,F.R. e DANCHIN,R.V. (1974) - Discrete nodules from the Artur de Paiva Kimberlite, Angola. Carnegie Inst.Wash., Yearbook 73, p.278-282.

BOYD,F.R. e DAWSON,J.B. (1972) - Kimberlite garnets and pyroxene -ilmenite intergrowths. Carnegie Inst.Wash., Yearbook 71 , p. $373-378$.

BOYD,F.R. e ENGLAND, (1964) - The system enstatite-pyrope. Carnegie Inst.Wash., Yearbook 63, p. 157-161.

BOYD,F.R.; FINGER,L.W. e CHAYES,F. (1969) - Computer reduction of electron probe data. Carnegie Inst. Wash. .Yearbook 67, p. 210-215.

BOYD,F.R. e NIXON,P.H. (1970) - Kimberlite diopsides. Carnegie Inst. Wash., Yearbook 68, p. 324-329.

BOYD,F.R. e NIXON,P.H. (1972) - Ultramafic nodules from the Thaba Putsoa Kimberlite pipe. Carnegie Inst.Wash., Yearbook $71, p .362-373$.

BOYD,F.R. e NISON,P.H. (1973) - Structure of the Upper Mantle be neath Lesotho. Carnegie Inst. Wash., Yearbook 72, p.431445 .

BOYD,F.R. e NIXON,P.H. (1973a) - origin of the ilmenite-silicate nodules in kimberlites from Lesotho and South Africa. In: Lesotho Kimberlites P.254-268, edited by P.H.Nixon, Lesotho Nat.Dev.Corp., Maseru. 
BOYD,F.R. E NIXON,P.H. (1975) - origin of the ultramafic nodules from some kimberlites of northern Lesotho and the Monas tery Mine, South Africa. Physics and Chemistry of Earth vol. 9, p.431-454.

BREWSTER,D. (1835) - On the origin and structure of the diamond. Geol.Soc.Trans., vol.3, p.455.

BUNCH,T.E.; KEIL,K. e OLSEN,E. (1970) - Mineralogy and petrology of silicate inclusion in iron meteorites. Contr. Mineral. Petrol., vol.25, p.297-340.

BUNCH,T.E.; KEIL,K. e SNETSINGER,K.G. (1967) - Chromite composition in relation to chemistry and texture of ordinary chondrites. Geochim.et Cosmochim. Acta, vol.31, p.15691582 .

BURNS,R.G. (1975) - on the ocurrence and stability of divalent chromium in olivines included in diamonds. Contr. Mineral. Petrol., vol.51, p.213-221.

BUTLER,P. Jr. (1972) - Compositional characteristios of olivines from Apolzo 12 samples. Geochim.et Cosmochim.Acta, vol. $36, p .773-786$.

BYKOVA YU.M. e GENSHAFT,YU.S. (1972) - Synthesis of chromegarmets in the pyrope-Knorxinguite series. Geokhimiya vol.10,p. $1291-1293$.

CAMARGO,W.G.R. e LEITE,C.R. (1968) - olivina: inclusão em diaman tes do Brasiz. Anais Acad.Bras.Cienc., Sup1.Esp.p.89-92.

CAMARGO,W.G.R. e LEITE,C.R. (1977) - olivine epitaxy in Brazilian diamonds. Anais Acad.Bras.Ciēnc., vol.48,p.234-244.

CARSWELL,D.A. e DAWSON,J.B. (1970) - Garnet peridotite xenoliths in South African kimberlites pipes and their petrogenesis. Contr.Miner.Petrol., vol.25, p.163-184.

CLARK,S.P. E RINGWOOD,A.E. (1964) - Density distribution and constitution of the mantze. Rev.Geophys. vol.2, p.35-68.

CLARKE,D.B. e MITCHELL,R.H. (1975) - Mineralogy and petrology of the kimberite from Somerset Island, N.W.T., Canada.Physics Chemistry of Earth, vol.9, p.123-135.

CLEMENT,C.R.; SKINNER,E.M.W. e SCOTT,B.H. (1977) - Kimberlite Re defined. Proc. 2nd Intern. Conference on Kimberlites $p$. 70-71, Santa Fe, New Mexico, U.S.A. 
CLIFFORD,T.N. (1970) - The Structural framework of Africa. In: African magmatism and tectonics p.1-26, edited by T.N. Clifford e I.G.Gass.

COES Jr.,L. (1955) - High pressure minerals. Journ.Amer. Ceram. v01. 38, p.298.

COHEN,E. (1876) - Uber Einschlusse in sud Afrikan-ischen Diamanten. Neues Jb.|Min.Geol.Pal.,p.752-753 (Citado p/Meyer, 1977).

COLONY,R.J. (1923) - An unusual quartz-diamond intergrowth. Amer. Journ.Sci., vol.5, p.400-403.

CORRENS,C.W. (1931) - Ueber Diamanten mit Quarzeinlagerungen.

Zeits. fur Kristallogr., vol.80, p.37-44.

COX,K.G.; GURNEY,J.J. e HARTE,B. (1973) - Xenoliths from the Mat soku pipe. In: Lesotho Kimberitites p. 76-100, edited by P.H.Nixon, Lesotho Nat.Dev.Corp., Maseru.

DANCHIN,R.V. e BOYD,F.R. (1976) - Uttramafic nodules from the Premier Kimberlite pipe, South Africa. Carnegie Inst. Wash., Yearbook 75, p.531-538.

DAVIS,B.T.C. e BOYD,F.R. (1966) - The Join $\mathrm{Mg}_{2} \mathrm{Si}_{2} \mathrm{O}_{6}$-CaMgSi $_{2} \mathrm{O}_{6}$ at 30 Kilobars and its application to pyroxenes from kimberlites. Journ. Gephys. Res., vol.71, p.3567-3576.

DAVIS,G.L. (1977) - The ages and uranium contents of zircons from kimberlites and associated rocks. Proc.2nd International Conf. on Kimberlites p.78-80, Santa Fe, New Mexico, U.S.A.

DAWSON,J.B. (1967) - A review of the geology of kimberitite. In: Ut tramafic and related rocks, p.269-278, edited by P.J. Wyllie. Wiley Sons, New York.

DAWSON,J.B. (1971) - The genesis of kimberlite. Diamond Research p. 2-7, London.

DAWSON,J.B. (1972) - Kimberlites and their relation to the mantle. Phi1.Trans.Roy.Soc.London (A) vol.271,p.297-311.

DAWSON,J.B. (1976) - New aspects of diamond geology. In: Physical properties of diamond, edited by J.Field. Academic Press (citado por Reid et al. 1976).

DAWSON,J.B. e SMITH,J.V. (1975) - Occurrence of diamond in a mica-garnet lherzolite in kimberlite. Nature,vol.254, p. 580-581. 
DAWSON,J.B. e STEPHENS,W.E. (1975) - Statistical analysis of garnets in kimberlite and associated xenoliths. Journ. Geo1., vol.83, p.589-607.

DE BEER,E.S. (1955) - The Diary of John Evelyn. Vol.2, p. 16201649, London.

DEER,W.A.; HOWIE,R.A. e ZUSSMAN,J. (1967) - Rock-forming minerals. Vo1.5, 371 p. Wiley \& Sons, New York.

DEMPSTER,A.N. e RICHARD,R. (1973) - Regional geology and structu re. In: Lesotho Kimberlites p.1-19, edited by P.H. Nixon, Lesotho Nat. Dev. Corp., Maseru.

DERBY,0.A. (1882) - os modos de ocorrência do diamante no Brasiz. Rev. Engenharia, Rio de Janeiro (citado por S.F.Abreu, 1973)

DERBY,0.A. (1898) - Brazilian evidence on the genesis of diamond. Journ.of Geo1.,vol. VI, p.121-146, Chicago.

DES CLOIZEAUX,M. (1855) - Note sur le diamant noir. Ann. Mines vol. 8, p. 304-306.

DRAPER,D. (1920) - The high-level diamond-bearing breccias of Di.a mantina, Braziz. Trans.Geol.Soc.S.Africa, vol.23, p.4351.

DUMAS,A. (1840) - Recherches sur le veritable poids atomique du carbonne. Comp.Rd.Acad.Sci. vo1.11, p.991.

EGGLER,D.H. (1975) - $\mathrm{CO}_{2}$ as a volatize component of the mantle: The system $\mathrm{Mg}_{2} \mathrm{SiO}_{4}-\mathrm{SiO}_{2}-\mathrm{H}_{2} \mathrm{O}-\mathrm{CO}_{2}$. Physics and Chemistry of Earth, vol.9, p.869-882, Pergamon Press; New York.

EGGLER,D.H.; MYSEN,B.0. e SEITZ,M.G. (1974) - solubility of $\mathrm{CO}_{2}$ in silicate liquids and crystals. Carnegie Inst. Wash., Yearbook 73, p.226-228.

ELTHON,D. e RIDLEY,W.I. (1977) - Mineral chemistry of the Premier Kimberlite. Proc. 2nd. Int. Conference on Kimberlites p. 101-103, Santa Fe, New Mexico, U.S.A.

EPPLER,W.F. (1961) - Inclusions in diamond. Journ.of Gemmol.vol. VIII, p. $1-13$.

FESQ,H.W.; BIBBY,D.M.; ERASMUS,C.S.; KABLE,E.J.D. e SELLSCHOP,J. P.F. (1975) - A comparative trace element study of diamonds from Premier, Finsch and Jagersfontein Mines, South Africa.Physics and Chemistry of Earth,vol.9,p.817-836. 
FRANK,F.C. (1969) - Diamonds and deep fluids in the upper mantle. In: The application of molern physics to the earth and planetary interiors, p.247-250, edited by S.K. Runcorn, Willey-Intersciences.

FRANTSESSON,E.V. (1970) - The petrology of kimberlites. Tradução inglesa por D.A.Brown. Dep.Geol., Australian National University, Publ. 150, $195 \mathrm{p}$.

FREYBERG,B. von (1932) - Ergebnisse geologischer Forschungen in Minas Gerais (Brasilien). Neues Jb.Min.Geol.und Palaont., Sonderband II, $400 \mathrm{p}$. Stuttgart.

FRICK,C. (1973) - Kimberlitic izmenites. Trans.Geo1.Soc. South Africa, vol. 76, p. 85-94.

FUTERGENDLER,S.I. (1956) - Estudo de inclusões em diamantes pelo método da anälise estrutural por difracão de raios $x$. Zap. Vses. Mineral. Obsch., vol.85, p.568-569(Em russo). FUTERGENDLER,S.I. (1958) - Estudo de inclusões sölidas do diaman te por meio de raios $x$. Soviet Phys.Crystallogr.,vol.3, p.494-497 (Em russo).

FUTERGENDLER,S.I. (1960) - Estudo por meio de raios $X$ de inclusões sölidas de diamantes dos urais e de Yakutia. Mat. Vses. Nauk Geol. Inst., vol.40, p.3-87 (Em russo).

FUTERGENDLER,S.I. (1965) - Exemplos de intercrescimentos entre diamante e rutizo. Dok1.Akad.Nauk SSSR, Nọ 1, p.172-173 (Em russo).

FUTERGENDLER,S.I. e FRANK-KAMENTSKY,V.A.(1961) - Inclusões orien tadas de olivina, granada e cromioespinëzio em diamante. Zap.Vses.Min.0bshch., vo1.90, p.230-236 (Em russo).

GIARDINI,A.A.; HURST,V.J.; MELTON,C.E. e STORMER,J.C. (1974) Biotite as a primary inclusion in diamond. Amer. Minera log., vol.59, p.783-789.

GIARDINI,A.A. e MELTON,C.E. (1975) - Chemical data on a coloriess Arkansas diamond and its black amorphous C-Fe-Ni-S inclusion. Amer.Mineralog., vol.60, p.934-936.

GNEVUSHEV,M.A. e NIKOLAEVA,E.S. (1961) - Inclusões sölidas em diamantes dos depositos de yakutia. Trudy Yakutzk. Fil. Sib.otd.Akad.Nauk SSSR, Ser.Geol. Sb.,no 6, p.97-105(Em russo). 
GOMES,C.B. e GIRARDI,V.A.V. (1973) - Principios e aplicações da microssonda eletrönica. Ciēncia e Cultura, vol.25, p. $711-722$.

GORCEIX,H. (1882) - Sobre as jazidas diamantiferas de Minas Gerais, Brasiz. Rev.Engenharia, Rio de Janeiro(citado por S.F.Abreu, 1973).

GUBELIN,E. (1952) - Inclusions in diamonds. Journ.Gemmo1.vo1.3, p. $174-187$.

GUBELIN,E. (1969) - On the nature of mineral inclusions in gemstones. Journ.Gemmol., vol.11, p.149-192.

GUBELIN,E. (1977) - Analytical results of poly-mineralic sulfide inclusions in diamond. Gems and Gemology, vol. XV, p. $322-327$.

GUIMARAES,D. (1927) - o diamante no estado de Minas Gerais.Serviço Geolögico e Mineralōgico do Brasil, Boletimnọ 24, p. $3-46$.

GUIMARAES,D. (1930) - Gënese do diamante. An.Acad.Bras. Cienc. Tomo III, p.75-86, Rio de Janeiro.

GUIMARAES,D. (1932) - Sobre a rocha matriz do diamante de Minas Gerais. An.Acad.Bras.Cienc., Tomo IV, p.173-176, Rio de Janeiro.

GUIMARAES,D. (1961) - Fundamentos da metalogênese e os depósitos minerais do Brasiz. Departamento Nacional da Produ ção Mineral, Divisão de Fomento, Boletim nọ 109, Rio de Janeiro.

GURNEY,J.J. (1975) - The origin of kimberlite: modern concepts. Trans.Geo1.Soc.South Africa, vo1. 77, p.753-761.

GURNEY,J.J.; FESQ,H.W. e KABLE,E.J.D. (1973) - Clinopyroxene-iz menite intergrowths from kimberlite: A re-appraisal.In: Lesotho Kimberlites p. 238-253, edited by P.H. Nixon, Lesotho Nat. Dev. Corp., Maseru.

GURNEY,J.J.; HARRIS,J.W. e RICHARDS,R.S. (1977) - Sizicate and oxide inclusions in diamonds from the Finsch kimberlites pipe. Proc. 2nd. Int.Conference on kimberlites $p$. 134-136, Santa Fe, New Mexico, U.S.A. 
GURNEY,J.J.; SIEBERT,J.C. e WHITFIELD,G.G. (1969) - A diamondiferous eclogite from the Roberts Victor mine.Geol.Soc. South Africa, Sp. Publ. no2, p.351-357.

GURNEY,J.J. e SWITZER,G.S. (1973) - The discovery of garnets closely related to diamonds in the Finsch Pipe, South Africa. Contrib.Mineral.Petrol., vol.39, p.103-116.

HADIDIACOS,C.G.; FINGER,L.W. e BOYD,F.R. (1971) - Computer reduction of electron probe data. Carnegie Inst. Wash. Yearbook 69, p.294.

HAGGERTY,S.E. (1975) - The Chemistry and genesis of opaque minerals in kimberlites. Physics and Chemistry of Earth vol. 9, p.295-307.

HARRIS,J.W. (1966) - The relative orientation of solid mineral inclusions in diamond. Proc. 5th General. Meeting International Mineralogical Association, p.163-168.

HARRIS,J.W. (1968) - The recognition of diamond inclusions.Pt.1: Syngenetic mineral inclusions. Pt. 2: Epigenetic mineral inclusions. Ind.Diam.Rev., p.402-410 e 458-46i.

HARRIS,J.W. (1972) - Black material on mineral inclusions and in internal fracture planes in diamond. Contrib. Mineral. Petrol., vol.35, p.22-23.

HARRIS,J.W.; HENRIQUES,R. e MEYER,H.0.A. (1967) -Orientation of silicate inclusions in natural diamond.crystallography vo1.7, p.118-123.

HARRIS,J.W.; MILLEDGE,H.J.; BARRON,T.H.J. e MUNN,R.W. (1970)Thermal expansion of garnets included in diamondsourn. Geophys. Res., vol.75, p.5775-5792.

HARRIS,J.W. e VANCE,E.R. (1972) - Induced graphitization around crystalline inclusions in diamonds. Contrib. Mineral. Petrol., vo1.35, p.227-234.

HARRIS,P.G. E MIDDLEMOST,E.A.K. (1969) - The evolution of kimberlites. Lithos, vol.3, p.77-83.

HARTE,B. e GURNEY,J.J. (1975) - ore mineral and phlogopite mine ralization within ultramafic nodules from the Matsoku Kimberlite Pipe, Lesotho. Carnegie Inst. Wash.,Yearbook 74, p. $528-536$. 
HARTING,P. (1859) - Ein diamant mit eingeschlossen KrystaZZen. Neues Jb. Min.Geo1.Pa1.,p.192-193 (Citado p/Meyer, 1977).

HEARN,B.C. e BOYD,F.R. (1975) - Garnet peridotite xenoliths in a Montana, U.S.A., Kimberlite. Physics and Chemistry of Earth, vol. 9, p.247-255. Pergamon Press, New York.

HORNUNG,G. e NIXON,P.H. (1973) - Chemical variations in the Knor ringuite-rich garnets. In: Lesotho Kimberlites p. 122127, edited by P.H.Nixon, Lesotho Nat.Dev.Corp., Maseru. IRVINE,T.N. (1965) - Chromium spinel as petrogenetic indicator. Part I: Theory. Can.Journ. Earth Sci., vol.2,p.648-672. IRVINE,T.N. (1967) - Chromium spinel as petrogenetic indicator. Part II: Petrologic application. Can.Journ.Earth Sci.. vol. $4, p .71-104$.

ITO,K. e KENNEDY,G.C. (1967) - Melting and phase relations in a natural peridotite to kilobars. Amer.Journ.Sci.,Sci.,vol. 265, p.519-539.

ITO,K. e KENNEDY,G.C. (1970) - The fine structure of the basalteclogite transition. Minera1.Soc.Amer.Spec.Pap.no 3, p 77-83.

JACKSON,E.E. (1969) - Chemical variation in coexisting chromite and olivine in chromitite zones of the stillwater complex. Econ.Geo1., Monogr., vol.4, p.41-71.

JANNETAZ,E. (1879) - Sur les colorations du diamant dans za zumiere polarises. Bul1.Soc.Franc.Mineral., vol.2, p. 124131.

KELL,K. (1967) - Meteorite Composition. In: Handbook of Geochemistry, vol. I, p.78-110. Edited by K.H.Wedepoh1,Springer-Verlag, Berlin.

KENNEDY,G.C. e NORDLIE,B.E. (1968) - The genesis of diamond deposits. Econ.Geol., vol.63, p.495-503.

KENNGOTT,A. (1853) - Mineral Notizen. Sber.Akad.Wiss.Wen. MathsNaturn., vol.10, p.174-184.

KHARKIV,A.D.; SOBOLEV,N.V. e CHUMIRIN,K.G. (1972) - Inclusions of chrome diopside in zircon from kimberitite of Malo-Bo tuoby district. Zag.Vses.Mineralog.0bshchestva,v01.101, p. $431-433$. (Em russo). 
KRESTEN,P. (1973) - The geology of Lemphane pipes and neighbouring intrusions. In: Lesotho Kimberlites p. 159-167, edited by P.H.Nixon. Lesotho Nat.Dev.Corp., Maseru.

KURITA,T. (1973) - Upper mantie structure in the central United States from $P$ and $S$-wave spectra. Phys.Earth Planet. Int., vol.8, p.177-201.

KUSHIRO, I. e AOKI,K.I. (1968) - Origin of some eclogite inclusions in kimberlite. Amer.Mineralog., vol.53,p.1347-1367.

LANG,A.R. (1970) - Diamond accumulation in the upper mantle. Nature, vol.226, p.345.

LEITE,C.R. (1969) - Cristalografia e Mineralogia do diamante da região do Triangulo Mineiro. Tese de doutoramento apresentada à Faculdade de Filosofia, Ciēncias e Letras da Universidade de São Paulo, $102 \mathrm{p}$.

LEONARDOS, O.H. (1959) - Diamante. Eng.Miner.Metal., vol.XXX, no $175, \mathrm{p} .4-8$.

LIVSHITS,L.D.; DELITSIN,I.S.; LARIONOV,L.V. e PETROV,V.P. (1973)Coesite-quartz transformation at high pressures. Intern. Geol.Rev., vol.15, p.1203-1205.

MAACK,R. (1926) - Eine forschungsreise uber das hochland von Minas Gerais zum Paranahyba. Zeitschr.d.Gellsch.f.Erdkunde, p.310-323, Berlim.

MacGREGOR,I.D. (1974) - The system MgO-Al ${ }_{2} \mathrm{O}_{3}-\mathrm{SiO}_{2}$ : the solubility of $\mathrm{Al}_{2} \mathrm{O}_{3}$ in enstatite for spinel and garnet peridoti te compositions. Amer.Mineralog., vol.59, p.110-119.

MacGREGOR, I.D. (1975) - Petrologic and thermal structure of the upper mantie beneath south Africa in the Cretaceous. Phy sics and Chemistry of Earth, vol.9, p.455-466.

MacGREGOR, I.D. e BASU,A.R. (1974) - Thermal structure of the lithosphere a petrologic model. Science, vol.185, p.10071011 .

MacGREGOR, I.D. e CARTER,J.L. (1970) - The chemistry of clinopyro xenes and garnets of eclogite and peridotite xenoliths from the Roberts Victor Mine, South Africa. Phys. Earth Planet. Int., vol.3, p.391-397. 
MARX,P.C. (1972) - Pyrrhotite and the origin of terrestrial diamonds. Mineralog. Mag., vol.38, p.636-638.

MCCALLISTER,R.H.; MEYER,H.0.A. e BROOKINS,D.C. (1975) -Pyroxeneilmenite xenoliths from the stockdale pipe, Kansas: chemistry, crystallography and oxigin. Physics and Chemistry of Earth, vol.9, p.287-293.

MCCALLUM,M.E. e EGGLER,D.H. (1971) - Mineralogy of the sloan dia treme, a Kimberite pipe in northern Larimer Country, Co Lorado. Amer.Mineralog., vol.56, p.1735-1749.

MCCALLUM,M.E. e EGGLER,D.H. (1976) - Diamonds in an upper mantze peridotite nodule from kimberlite in southern Wyoming. Science, vol.192, p.253-256.

MCGETCHIN,T.R. e SILVER,L.T. (1970) - Compositional relations in minerals from kimberlite and related rocks in the Moses Rock Dike, San Juan County, Utah. Amer.Mineralog., vol. $55, \mathrm{p} .1738-1771$.

MCGETCHIN,T.R. e ULRICH,G.W. (1973) - Xenoliths in maars and dia tremes with inferences for the Moon, Maars, and Venus, Journ.Geophys.Res., vo1.75, p.1833-1853.

MEOARIS Jr., L.G. (1969) - Partitioning of $\mathrm{Fe}^{2+}$ and $\mathrm{Mg}^{2+}$ between coexisting synthetic olivine and orthopyroxene. Journ. Sci., vol.267, p.954-968.

MELTON,C.E. e GIARDINI,A.A. (1974) - The composition and signifi cance of gas released from natural diamonds from Afxica and Brazil. Amer.Mineralog., vol.59, p.775-782.

MELTON,C.E. e GIARDINI,A.A. (1975) - Experimental results and a theoretical interpretation of gaseous inclusions found in Arkansas natural diamonds. Amer. Mineralog.,vol.60,p. 413-417.

MELTON,C.E.; SALOTTI,C.A. e GIARDINI,A.A. (1972) - The observation of nitrogen, water, carbon dioxide, methane and argon as impurities in natural diamonds. Amer. Mineralog., vol.57, p.1519-1523.

MEYER,H.0.A. (1967) - Inclusions in diamond. Carnegie Inst.Wash. Yearbook 66, p.446-450.

MEYER,H.0.A. (1968) - Chrome pyrope: an inclusion in natural dia mond. Science, vol.160, p.1446-1447.

MEYER,H.O.A. (1975) - Chromium and the genesis of diamond. Geochim.et Cosmochim. Acta, vo1.39, p.929-936. 
MEYER,H.O.A. (1975a) - Kimberitite from Norris Lake Eastern Tennesse: Mineralogy and Petrology. Journ.Geol., vol.83,p. 518-526.

MEYER,H.0.A. (1977) - Mineralogy of the upper mantle: a review of the minerals in mantie xenoliths. Earth Sci.Rev.vol. 13, p. $251-281$.

MEYER,H.O.A. e BOYD,F.R. (1968) - Mineral inclusions in diamond. Carnegie Inst. Wash., Yearbook 67, p.130-135.

MEYER,H.O.A. e BOYD,F.R. (1969) - Inclusion in diamond. Carnegie Inst. Wash., Yearbook 68, p.315-322.

MEYER,H.O.A. e BOYD,F.R. (1972) - Composition and origin of crystal line inclusions in natural diamonds. Geochim. et cosmochim. Acta, vol.36, p.1255-1273.

MEYER,H.O.A. e BROOKINS,D.G. (1971)-Eclogite xenoliths from Stockdale Kimberlite, Kansas. Contrib.Mineral. Petrol., v01.34, p. $60 \div 72$.

MEYER,H.0.A.; TSAI,H.M.; MOREAU,J.; MILLEDGE,J.H. (1977) - Mineral inclusions in diamond: Premier, Jagersfontein and Finsch Kimberlites, South Africa, and Willians Mine, Tan zania. Proc.2nd. Int.Conference on Kimberlites, p. 241243, Santa Fe, New Mexico, U.S.A.

MEYER,H.O.A. e SVISERO,D.P. (1973) - Mineral inclusions in Brazi lian diamonds. Proc.Int.Conference on Kimberlites p. 125-128, Cape Town, South Africa.

MEYER,H.O.A. e SVISERO,D.P. (1975) - Mineral inclusions in Brazi lian diamonds. Physics and Chemistry of Earth,vo1.9, p. 785-795, Pergamon Press, New York.

MEYER,H.O.A. E TSAI,H.M. (1976) - The nature and significande of mineral inclusions in natural diamond: A Review. Miner. Sci.Eng., vol.8, p.242-261.

MEYER,H.O.A. e TSAI,H.M. (1976a) - Mineral inclusions in diamond: temperature and pressure of equilibration. Science,vol. 191, p. 849-851.

MILASHEV,V.A. (1965) - Petroquimica dos kimberititos de Yakutia e fatores relacionados à formacão do diamante. Editora Ne dra, 159 p., Moscou (Em russo). 
MILLEDGE,H.J. (1961) - Coesite as an inclusion in G.E.C.synthetic diamonds. Nature, vol.190, p.1181.

MITCHELL,R.H. (1973) - Magnesian ilmenites and its role in kimberlite petrogenesis. Journ.Geol., vol.81, p.301-311.

MITCHELL,R.H. (1975) - Theoretical aspects of gaseous and isoto pic equilibria in the system C-H-O-S with application to Kimberlite. Physics Chemistry of Earth, vo1.9, p. 903-915, Pergamon Press, New York.

MITCHELL,R.H. e CROOCKET;J.H. (1972) - Diamond genesis: a synthe sis of opposing views. Mineral. Depos., vol.6,p. 392-403

MITCHELL,R.H. e FRITZ,P. (1973) - Kimberiite from somerset Island, District of Franklin, NWT. Can.Journ. Earth Sci., vo1.10, p.384-393.

MITCHELL,R.H. e GIARDINI,A.A. (1953) - oriented olivine inclusions in diamond. Amer. Mineralog., vo1.38,p.136-138.

MORAES,L.J. e GUIMARAES,D. (1930) - Geologia da região diamantí fera do norte de Minas Gerais. An. Acad.Bras. Cienc. Tomo II, p.153-186.

NIXON,P.H. e BOYD,F.R. (1973) - Petrogenesis of the granuzar and sheared ultrabasic nodule suite in kimberlites. In: Lesotho Kimberlites p.48-56, edited by P.H.Nixon, Leso tho Nat.Dev.Corp., Maseru.

NIXON,P.H.; BOYD,F.R. e BOULLIER,A.M. (1973) - The evidence of kimberitite and its inclusions on the constitution of the outer part of the Earth. In: Lesotho Kimberiites p.312-318, edited by P.H.Nixon, Lesotho Nat.Dev.Corp., Maseru.

NIXON,P.H. e HORNING,G. (1968) - A new chromiun garnet end menber, Knorringuite, from kimberlites. Amer. Mineralog. Vo1.53,p.1833-1840.

NIXON,P.H.; KNORRING,0.Von e ROOKE,J.M. (1963) - Kimberiites and associated inclusions: a mineralogical and geochimical study. Amer. Mineralog., vol.48,p.1090-1132.

NOVAK,G.A. e MEYER,H.O.A. (1970) - Refinement of the crystal structure of a chrome pyrope garnet: an inclusion in natural diamond. Amer.Mineralog., vol.55,p.2124-2127. 
O'HARA,M.J. e YODER,H.S. (1967) - Formation and fractionation of basic magmas at high pressures. Scot.Journ.Geol., vol. 3, p. 67-117.

OPPENHEIM,V. (1936) - Sedimentos diamantiferos do Paranā. Bol. avulso nọ 9 do Departamento Nacional da Produção Mineral, p. 1-14, Rio de Janeiro.

ORLOV,YU.L. (1959) - Inclusões singenéticas e epigenéticas em cristais de diamantes. Trudy Minera1. Muzeya Akad. Nauk SSSR, vo1.10, p.103-120.

PETZHOLDT,A. (1842) - Beitrage aur Naturge-Schichte des Diamanten. Dresden. (citado por Meyer e Tsai, 1976).

PIKE,D.R.; NALDRETT,A.J. e ECKSTRAND,0.R. (1973) - Archaean ultramafic flows in Munro Township, Ontario. Bull. Geol. Soc.Amer., vo1.84, p.955-970.

PRINZ,M.; MANSON,D.V.; HLARA,P.E. e KEIL,K. (1975) - Inclusions in diamond: garnet therzolite and eclogite assemblages. Physics and Chemistry of Earth, vol.9, p.797-815.Pergamon Press, New York.

REID,A.M.; BROWN,R.W.; DAWSON,J.B. e WHITFIELD,G.G. (1976) - Gar net and pyroxene compositions in some diamondiferous eclo gites. Contrib. Mineral.Petrol., vol.58, p.203-220.

REID,A.M. e HANOR,J.S. (1970) - Pyrope in kimberlite. Amer. Mine ralog., vol.55, p.1374-1379.

RIMANN,E.T. (1917) - A kimberlita no Brasiz. Annaes da Escola de Minas de Ouro Preto, vol.15, p.27-32.

RINGW00D,A.E. (1969) - Composition of the crust and upper mantle. Geophys.Monogr., vol.13, p.1-17.

RINGW00D,A.E. (1977) - Synthesis of Pyrope-Knorringuite solid so Zution series. Earth Plan.Sci.Lett.,vol.36,p.443-448.

RINGWOOD,A.E. e LOVERING,J.F. (1970) - Significance of pyroxeneilmenite intergrowths among kimberlite xenoliths. Earth Plan.Sci.Lett., vo1.7, p.371-375.

ROEDDER,E. (1965) - Liquid CO ${ }_{2}$ inclusions in olivine bearing nodules and phenocrystals from basalts. Amer. Mineralog., vo1. 50, p.1746-1782. 
ROLFE,D.G. (1973) - The geology of Kao kimberlite pipes. In: Lesotho Kimberlites p.101-109, edited by P.H.Nixon, Lesotho Nat.Dev.Corp., Maseru.

ROST,F.; BEERMANN,E. e AMTHAWER,G. (1975) - Chemical investigation of pyrope garnets in the stockdale Kimberlite Intrusion, Riley County, Kansas. Amer.Mineralog., vol.60, p. $675-680$.

SHARP,W.E. (1966) - Pyrrhotite: a common inclusion in South Afri can diamonds. Nature, vo1.211, p.402-403.

SMITH,C.B.; MCCALLUM,M.E. e EGGLER,D.H. (1976) - Ciinopyroxeneilmenite intergrowths from the Iron Mountain Kimberlite District, Wyoming. Carnegie Inst. Wash., Yearbook 75, p. 542-544.

SMITH,J.V. e DAWSON,J.B. (1975) - Chemistry of Ti-poor spinels, ilmenites and rutiles from peridotite and eclogite xenoliths. Physics Chemistry of Earth, vol.9, p.309-322.

SOBOLEV,N.V. (1970) - Eclogites and pyrope peridotites from the kimberlites of Yakutia. Phys.Earth Planet., vol. 3, p. 398-404.

SOBOLEV,N.V. (1974) - As inclusões profundas dos kimberlitos e o problema da composicão do manto superior. Editora Nauka, Divisão Siberiana, Novosibirsk, 264 p. (Em russo).

SOBOLEV,N.V.; BARTOSHINSKY,Z.V.; YEFIMOVA,E.S.; LAVRENT'YEV, YU. G. e POSPELOVA,L.N. (1970) - Associacão de olivina, gra nada e cromiodiopsidio em um diamante de yakutia. Dok1. Akad.Nauk SSSR, vol. 192, p.1349-1353. (Em russo).

SOBOLEV,N.V. e BOTKUNOV,A.I. (1972) - Inclusões cristalinas de diamante com morfologia octaédrica. Dok1.Akad.Nauk SSSR, vo1.204, p.192-196. (Em russo).

SOBOLEV,N.V. e BOTKUNOV,A.I. e KARKIV,A.D. (1966) - Uma nova des coberta de eclogito diamantifero no kimberlito Mir, yakutia. Geo1.Geophys., vol.11, p.114-116. (Em russo).

SOBOLEV,N.V.; BOTKUNOV,A.I.; LAVRENT'YEV,YU.G. e POSPELOVA, L.N. (1971) - Peculiaridades da composiça dos minerais coexistentes com diamantes do kimberitto Mir, Yakutia.Zap. Vses. Mineralog. Obshchesta, vol. 100, p.558-564. 
SOBOLEV,N.V.; GNEVUSHEV,M.A.; MIKHAILOVSKAIA,L.N.;FUTERGENDLER, S.I.; SHEMANINA,E.I.; LAVRENT'YEV, YU.G. e POSPELOVA, L.N. (1971a) - Composigão de granadas e piroxênios de diamantes dos Urais, URSS. Dok1.Akad.Nauk,SSSR, vol. 198, p.190-193. (Em russo).

SOBOLEV,N.V. e KUZNETSOVA,I.K. (1966) - Mineralogia de eclogitos diamantiferos. Dok1.Akad.Nauk SSSR, vol.167, 13651368 .

SOBOLEV,N.V.; KUZNETSOVA,I.K. e ZYUZIN,N.I. (1968) - The petrology of grospydite xenoliths from the Zagadochnaya kim berlite pipe in Yakutia. Journ.Petrol., vol.9,p.253-280. SOBOLEV,N.V.; LAVRENT'YEV,YU.G.; POKHILENKO,N.P. e USOVA, L.V. (1973) - Chrome-rich garnets from the kimberitites of Yakutia and their parageneses. Contrib.Mineral.Petrol. vol. 40, p.39-52.

SOBOLEV,N.V.; LAVRENT'YEV,YU.G.; POSPELOVA,L.N. E SOBOLEV, E.V. (1969) - Cromiopiropos de diamantes de Yakutia. Dok1. Akad.Nauk SSSR, vol.189, p.162-165. (Em russo).

SOBOLEV,N.V.; LAVRENT'YEV,YU.G. e USOVA,L.V. (1972) - EZementos tracos em rutilos de eclogitos. Geol.e Geophys., vol. 11, p.108-112. (Em russo).

SOBOLEV,N.V. e POKHILENKO,N.P. (1975) - Peculiar compositions of chrome spinels in diamonds from Yakutian Kimberlites. Geol.Geophys., vol.11, p.7-24. (Em russo).

SOBOLEV,V.S.; DOBRETSOV,N.L. e SOBOLEV,N.S. (1975) - Xenólitos profundos e o manto superior. Editora Nauka,Divisão Si beriana, Novosibirsk, 269 p. (Em russo).

SOBOLEV,V.S.; NAY,B.S.; SOBOLEV,N.V.; LAVRENT'YEV,YU.G. e POSPELOVA,L.N. (1969a) - Xenölitos de serpentinitos diamantiferos do kimberlito Aykhal, Yakutia. Dokl. Akad. Nauk SSSR, vo1.188, p.1141-1143. (Em russo).

SOBOLEV,V.S.; SOBOLEV,N.V. e LAVRENT'YEV,YU.G. (1972a) - Inelusões em diamantes de eclogitos diamantiferos.Dok1.Akad. Nauk SSSR, vo1.207, p.164-167. (Em russo).

SOBOLEV,V.S.; SOBOLEV,N.V. e LAVRENT'YEV,YU.G. (1975a) - Chrome-rich pyroxens from the kimberlites of Yakutia. Neues Jb.Miner.Abh., vo1.123, p.213-218. 
SPENCER,L.J. (1924) - An inclusions of magnetite in diamond. Mineralog.Mag., vol.22, p.245-247.

SUTTON,J.R. (1907) - The relationship between diamond and garnets. Nature, vol.75, p.488.

SUTTON,J.R. (1921) - Inclusions in diamond from South Africa. Mi neralog. Mag., vol.19, p.208-210.

SUTTON,J.R. (1928) - Diamond: a descriptive treatise. T. Murby, London.

SVISERO,D.P. (1969) - Microscopia eletrônica de microestruturas de diamantes do Brasiz. Tese de Mestrado apresentada à Faculdade de Filosofia, Ciēncias e Letras da Universida de de São Paulo, 39 p.

SVISERO,D.P. (1971) - Mineralogia do diamante da região do Alto do Araguaia, MT. Tese de Doutoramento apresentada ao Instituto de Geociēncias e Astronomia da Universidade de São Paulo, $137 \mathrm{p}$.

SVISERO,D.P. (1971a) - Inclusões minerais em diamantes aluvionares dos rios Gareas e Araguaia,MT. Anais do 250 Congr. Soc.Bras.Geol., vol.3, p.227-233.

SVISERO,D.P. (1974) - o diamante das regiões centroleste de Mato Grosso e sudoeste de Goiás. Parte III: Inclusões minerais. Rev.Gemologia, vol.40, p.33-42.

SVISERO,D.P. e GOMES,J.B. (1977) - Composição e origem de inclusões minerais em diamantes da Venezuela. Boletim do Ins tituto de Geociēncias da Universidade de São Paulo,vol. 8, p. $21-30$.

SVISERO,D.P.; HASUI,Y. e DRUMOND,D. (1978) - A Provincia Kimberlitica do Alto Paranaiba, Minas Gerais. Boletim do Instituto de Geociēncias da Universidade de São Paulo, (no pre10).

SVISERO,D.P.; MEYER,H.0.A. e TSAI,H.M. (1977) - Kimberlite minerals from Vargem (Minas Gerais) and Redondão(Piaui) dia tremes, Brazil; and Garnet Lherzolite Xenolith from Redondão diatreme. Rev.Brasileira de Geociências,vol.7.p. $1-13$. 
SVISERO,D.P.; MEYER,H.0.A. e TSAI,H.M. (1977a) - Kimberlites in Brazil: An Initial Report. Proc. 2nd. International Con ference on Kimberlites, p.350-352, Santa Fe, New Mexico, U.S.A.

SVISERO,D.P. e PIMENTEL,C.A. (1970) - Microestruturas em superfí cies (110) de diamantes do Brasiz. Anais I I Congresso Ibero-Americano de Cristalografia, p.137-147,Buenos Aires, Argentina.

SVISERO,D.P. e VALARELLI,J.V. (1977) - Partisão Mg/Fe ${ }^{2+}$ entre oli vinas e ortopiroxênios coexistentes em diamantes naturais. An.Acad.Bras.Cienc.,vol.49, p.237-241.

SWITZER,G.S. (1975) - Composition of garnet xenocrysts from three kimberlite pipes in Arizona and New Mexico. Miner. Sci. Investig., no19, p.1-21, edited by B.Mason.

TSAI,H.M.; SHIEH,Y.N. e MEYER,H.0.A. (1977) - Mineralogy and $S^{34} / S^{32}$ ratios of sulfides associated with kimberlite, xenoliths and diamonds. Proc. 2nd. Int. Conference on Kimberlites, p.359-361, Santa Fe, New Mexico, U.S.A.

VERWOERD,W.J. (1970) - Economic geology and genesis of kimberlite: A Review. Anais do XXIV Congr.Bras.Soc.Bras. Geol. Brasi1ia, p.51-70.

WAGNER,P.A. (1914) - The diamond fields of South Africa.Transvaal Leader, Johannesburg. Reimpresso por C.Struik em 1971, Cape Town, South Africa, $355 \mathrm{p}$.

WALLS,R.R. (1919) - The existence of diamond-bearing pipes in Brazil. Geo1.Mag., vol.57, p.447-449, London.

WHITELOCK,T.K. (1973) - Morphology of KaO Diamonds. In: Lesotho Kimberlites p.128-140, edited by P.H.Nixon,Lesotho Nat. Dev.Corp., Maseru.

WILLIANS, A.F. (1932) - The Genesis of diamond. 2 vols. E. Benn, London.

WYLLIE,P.J. (1967) - Ultramafic and related rocks. John Wiley and Sons, $464 \mathrm{p}$., New York.

WYLLIE,P.J. (1977) - Mantle fluid composition buffered by carbonate in peridotite- $\mathrm{CO}_{2}{ }^{-\mathrm{H}_{2}} \mathrm{O}$. Journ.of Geol.,vol.85, p. 187-208. 